\title{
Effects of Heat Treatment and Formulation on the Phase Composition and Chemical Durability of the EBR-II Ceramic Waste Form
}

prepared by

Chemical Engineering Division

Argonne National Laboratory 


\section{About Argonne National Laboratory}

Argonne is managed by The University of Chicago for the U.S. Department of Energy under contract W-31-109-Eng-38. The Laboratory's main facility is outside Chicago, at 9700 South Cass Avenue, Argonne, Illinois 60439. For information about Argonne and its pioneering science and technology programs, see www.anl.gov.

\section{Availability of This Report}

This report is available, at no cost, at http://www.osti.gov/bridge. It is also available

on paper to the U.S. Department of Energy and its contractors, for a processing fee, from:

U.S. Department of Energy

Office of Scientific and Technical Information

P.O. Box 62

Oak Ridge, TN 37831-0062

phone (865) 576-8401

fax (865) 576-5728

reports@adonis.osti.gov

\section{Disclaimer}

This report was prepared as an account of work sponsored by an agency of the United States Government. Neither the United States Government nor any agency thereof, nor The University of Chicago, nor any of their employees or officers, makes any warranty, express or implied, or assumes any legal liability or responsibility for the accuracy, completeness, or usefulness of any information, apparatus, product, or process disclosed, or represents that its use would not infringe privately owned rights. Reference herein to any specific commercial product, process, or service by trade name, trademark, manufacturer, or otherwise, does not necessarily constitute or imply its endorsement, recommendation, or favoring by the United States Government or any agency thereof. The views and opinions of document authors expressed herein do not necessarily state or reflect those of the United States Government or any agency thereof, Argonne National Laboratory, or The University of Chicago. 
ANL-05/32

\author{
ARGONNE NATIONAL LABORATORY \\ 9700 South Cass Avenue \\ Argonne, IL 60439-4837
}

\title{
Effects of Heat Treatment and Formulation on the Phase Composition and Chemical Durability of the EBR-II Ceramic Waste Form
}

\author{
W.L. Ebert, ${ }^{1}$ N.L. Dietz, ${ }^{1}$ and D.E. Janney ${ }^{2,3}$ \\ ${ }^{1}$ Chemical Engineering Division \\ ${ }^{2}$ Engineering Technology Division \\ Argonne National Laboratory-West \\ Idaho Falls, ID 83415
}

August 2005

${ }^{3}$ Currently at Materials and Fuels Complex, Idaho National Laboratory, Idaho Falls, ID 
INTENTIONALLY LEFT BLANK 


\section{CONTENTS}

$\underline{\text { Page }}$

ACKNOWLEDGEMENTS ...............................................................................

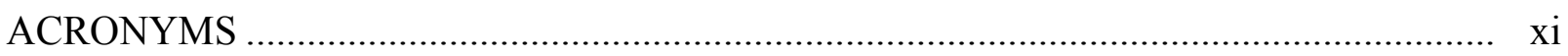

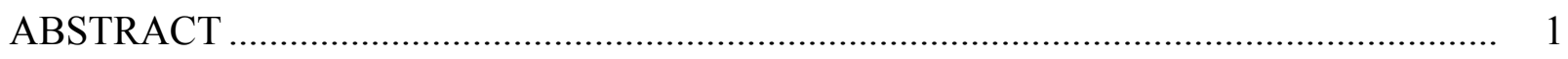

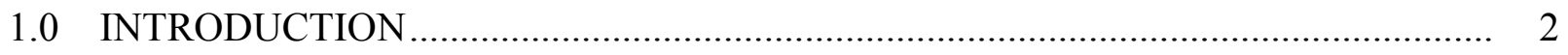

2.0 EFFECTS OF SALT LOADING AND GLASS LOADING ….............................. 4

2.1 PRODUCTION OF SALT-LOADED CWF PRODUCTS ................................ 4

2.1 .1 Components.................................................................................... 4

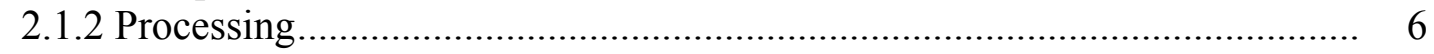

2.1.3 As-batched CWF and SLZ Compositions ............................................. 8

2.2 ANALYSIS OF SALT-LOADING CWF PRODUCTS .................................. 9

2.2.1 Preparation of Salt-Loaded CWF Test Samples...................................... 9

2.2.2 Compositional Analysis of Salt-Loaded CWF Products ............................ 9

2.2.3 Density Analysis of Salt-Loaded CWF Products ..................................... 11

2.2.4 XRD Analysis of Salt-Loaded CWF Products .......................................... 12

2.2.5 PCT with Salt-Loaded CWF Products ................................................... 13

3.0 EFFECTS OF HEAT TREATMENT ….............................................................. 18

3.1 GENERATION OF HEAT-TREATED CWF SAMPLES …........................... 19

3.1.1 Preparation of CWF Source Materials ................................................... 19

3.1.2 Short-Term Heat Treatment ................................................................ 20

3.2 ANALYSIS OF HEAT-TREATED CWF SAMPLES ................................... 21

3.2.1 Preparation of Heat-Treated CWF Test Samples .................................... 21

3.2.2 XRD of Heat-Treated CWF Samples ................................................. 21

3.2.3 PCT with Heat-Treated CWF Samples ............................................. 23

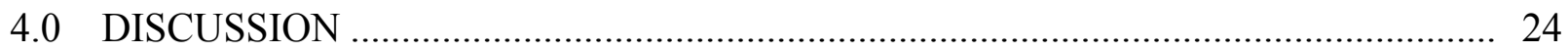

4.1 EFFECTS OF SALT AND BINDER GLASS CONTENTS …....................... 24

4.1.1 Effects on Phase Composition................................................................. 24

4.1.2 Effects on Chemical Durability .......................................................... 27

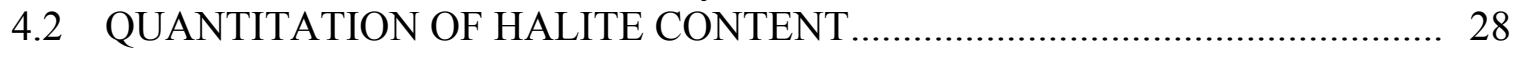

4.3 EFFECTS OF HEAT TREATMENT AND TTT DIAGRAM ........................... 29

4.4 COMPARISON OF CWF DURABILITY TO EA GLASS ............................. 30

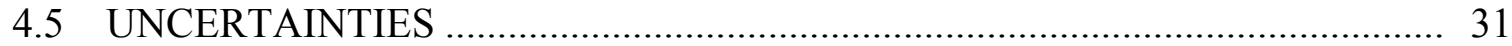

4.5.1 Presence of Powdery Inclusions in Salt-Loaded CWF Products ................ 31

4.5.2 Presence of Nepheline in CWF Products with the Nominal Composition.... 32

4.5.3 Measured CWF Composition ........................................................ 32

4.5.4 Quantitation of XRD Peaks ........................................................... 32 
CONTENTS (continued)

$\underline{\text { Page }}$

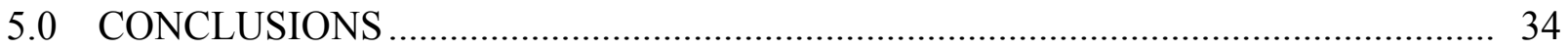

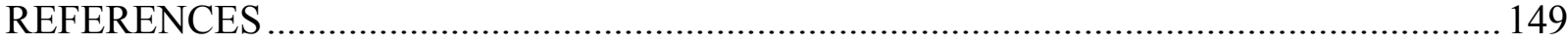

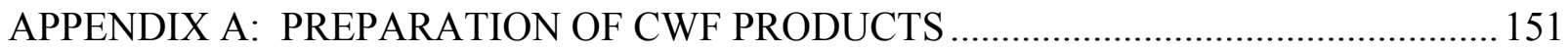




\section{TABLES}

1. Calculated batch compositions of salt-loaded CWF materials

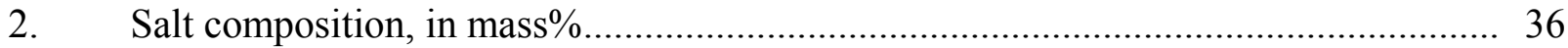

3. Particle size distributions of zeolite and binder glass, in mass $\%$.......................... 37

4. Processing data for salt-loaded CWF materials ............................................ 37

5. Compositions of glass, salt, and zeolite components, and as-batched compositions of salt-loaded CWF materials, in mass $\%$......................................... 38

6. Measured compositions of salt-loaded CWF materials and LRM glass standard....... 39

7. Data for density measurement and calculated specific surface area ....................... 42

8. XRD patterns of sodalite, nepheline, and halite ............................................... 43

9. Results of XRD analyses of salt-loaded CWF materials S1A, S2C, S4A, and $\mathrm{S} 5 \mathrm{~B}$

10. Results of XRD analyses of salt-loaded CWF materials S3A, S3B, S3C, and S3E

11. Results of XRD analyses of salt-loaded CWF materials G1A, G2A, G4A, and G5A

12. Results of XRD analysis of salt-loaded CWF material S1B

13. Compilation of relative peak heights used to identify sodalite, nepheline, and halite in salt-loaded CWF materials, in percent

14. Compilation of relative peak areas used to identify relative amounts of sodalite, nepheline, and halite in the different salt-loaded CWF materials, in percent

15. Test data for rapid water soluble tests with salt-loaded CWF materials 56

16. Results of rapid water soluble tests and free chloride measurements with salt-loaded CWF materials

17. Test data for 7-day PCTs with salt-loaded CWF materials 58 


\section{TABLES (continued)}

18. Results of 7-day PCTs with salt-loaded CWF materials

19. Results of XRD analyses of long-term heat-treated CWF materials heated at $400{ }^{\circ} \mathrm{C}$

20. Results of XRD analyses of long-term heat-treated CWF materials heated at $500{ }^{\circ} \mathrm{C}$

21. Compilation of area $\%$ values used to compare relative amounts of

sodalite, nepheline, and halite in long-term heat-treated CWF materials

22. Results of replicate XRD analyses of CWF source material PC10402 _.................. 78

23. Summary of relative XRD peak heights and peak areas for replicate analyses of source material PC10402, in percent

24. Results of XRD analyses of short-term heat-treated CWF materials heated at $600{ }^{\circ} \mathrm{C}$

25. Results of XRD analyses of short-term heat-treated CWF materials heated at $700{ }^{\circ} \mathrm{C}$

26. Results of XRD analyses of short-term heat-treated CWF materials heated at $800^{\circ} \mathrm{C}$

27. Results of XRD analyses of short-term heat-treated CWF materials heated at $850^{\circ} \mathrm{C}$

28. Peak heights used to identify sodalite, nepheline, and halite in XRD spectra of short-term heat-treated CWF samples.

29. Compilation of area\% values used to compare amounts of sodalite, nepheline, and halite in no-heat and heat-treated CWF samples

30. Test data for rapid water soluble tests with heat-treated CWF samples.................... 102

31. Test data for 7-day PCTs with heat-treated CWF samples .................................... 103

32. Results of RWS tests with short-term and long-term heat-treated CWF samples

33. Results of 7-day PCTs with short-term and long-term heat-treated

CWF materials 


\section{TABLES (continued)}

34. Calculated crystalline phase composition based on stoichiometry .......................... 106

35. Calculated fractions of $\mathrm{B}, \mathrm{Na}$, and $\mathrm{Si}$ in binder glass and sodalite, and mass fractions in CWF 106

36. Data for standard additions of $\mathrm{NaCl}$ to $\mathrm{CWF}$ material $\mathrm{PC} 10402$................................ 106

37. Results of XRD analyses of source CWF material PC10402 with added $\mathrm{NaCl}$......... 107

38. Calculated concentrations of halite in various CWF samples, in mass $\%$................. 110

39. Results of replicate PCTs with EA glass and salt-loaded CWF materials ................. 111

40. Glass compositions on an oxide basis, as total mass $\%$......................................... 112 


\section{FIGURES}

1. XRD spectra of salt-loaded CWF products.

2. Relative amounts of halite, sodalite, and nepheline formed in salt-loaded

CWF products

3. Chloride release in RWS tests with salt-loaded CWF products

4. Free chloride measured for batches of SLZs used to make salt-loaded

CWF products

5. Normalized elemental mass losses in 7-day PCT with salt-loaded

CWF products.

6. Oven cooling curves after heat treatments at 800 and $850{ }^{\circ} \mathrm{C}$

7. Crushed heat-treated CWF samples

8. XRD spectra of long-term heat-treated CWF samples heated at $400{ }^{\circ} \mathrm{C}$ 125

9. XRD spectra of long-term heat-treated CWF samples heated at $500{ }^{\circ} \mathrm{C}$ 128

10. Amounts of halite and sodalite in long-term heat-treated CWF samples. 131

11. XRD spectrum of CWF source material PC10402 that was not heat-treated.

12. XRD spectra of short-term heat-treated CWF samples heated at $600{ }^{\circ} \mathrm{C}$.

13. XRD spectra of short-term heat-treated CWF samples heated at $700^{\circ} \mathrm{C}$

14. XRD spectra of short-term heat-treated CWF samples heated at $800^{\circ} \mathrm{C}$.

15. XRD spectra of short-term heat-treated CWF samples heated at $850^{\circ} \mathrm{C}$.

16. Relative amounts of halite, sodalite, and nepheline in short-term heat-treated CWF samples

17. Results of 7-day PCT with long-term heat-treated CWF materials 


\section{FIGURES (continued)}

18. Results of 7-day PCT with short-term heat-treated CWF materials .......................... 143

19. Correlations in XRD spectra of salt-loaded CWF materials ................................. 144

20. Comparison of $\mathrm{Cl}$ concentrations in RWS tests and halite XRD peaks .................... 145

21. Correlation between amounts of halite and nepheline in salt-loaded CWF

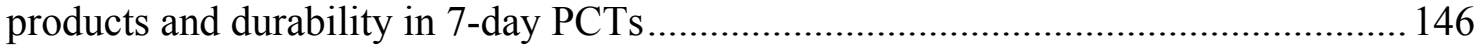

22. Correlation of $N L(\mathrm{~B})$ and $N L(\mathrm{Na})$ with $N L(\mathrm{Si})$ for 7-day PCTs with

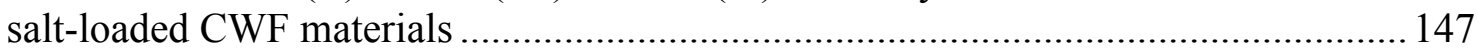

23. XRD peak area\% values for CWF material PC10402 with added $\mathrm{NaCl}$.................. 148

24. Time-Temperature-Transformation plot for heat-treated CWF products ................... 148 


\section{ACKNOWLEDGEMENTS}

This report provides a summary of work performed by scientists and engineers at Argonne National Laboratory-East in Illinois and Argonne National Laboratory-West in Idaho, which is now part of the Idaho National Laboratory.

The authors thank staff at Argonne National Laboratory-East and Argonne National LaboratoryWest for their contributions to this work. At Argonne-West: Ken Bateman for assistance in the manufacture of the salt-loaded CWF materials and for measuring the size distributions of the starting materials; Pam Crane for ICP-OES analyses of salt and glass compositions; Steve Frank for Karl Fischer analysis and X-ray diffraction of lumps from salt-loaded waste forms; Calvin D. Morgan for free chloride analyses; Scott McBride, Gregg Moedl, Gary Schwartzenberger, and Dave Hendrix for assistance with the argon glovebox; and Gregg Moedl, Eric Egan, and Ben Cowan for assistance with the V-mixer and furnace used to make the salt-loaded waste form. At Argonne-East: Yifen Tsai for performing ICP-MS analyses, Alice Essling for performing chemical dissolutions, Seema Naik for performing IC chloride analyses, Paul Johnson and Ben Tani for performing some of the XRD analyses, and Jeff Emery and Andy Hebden for technical assistance. The long-term heat-treated CWF samples were provided by Sean McDeavitt (Argonne-East, now at Purdue University).

This work was supported by the U.S. Department of Energy, Office of Nuclear Energy, Science and Technology. 


\section{ACRONYMS}

ANL Argonne National Laboratory

CWF ceramic waste form

CWF material ceramic waste form with a particular salt, zeolite, and binder glass content

CWF product ceramic waste form specimen made for testing

\begin{tabular}{|c|c|}
\hline EA & Environmental Assessment (glass) \\
\hline EBR-II & Experimental Breeder Reactor-II \\
\hline HIP & hot isostatic press \\
\hline HLW & high-level radioactive waste \\
\hline $\mathrm{IC}$ & ion chromatography \\
\hline ICP-MS & inductively coupled plasma-mass spectrometry \\
\hline ICP-OES & inductively coupled plasma-optical emission spectroscopy \\
\hline INL & Idaho National Laboratory \\
\hline LRM & low-activity reference material (glass) \\
\hline MCC-1 & Materials Characterization Center test method number 1 \\
\hline $\mathrm{NC}$ & normalized concentration \\
\hline NL & normalized elemental mass loss \\
\hline $\mathrm{PC}$ & pressureless consolidation \\
\hline PC CWF & ceramic waste form material made by the pressureless consolidation method \\
\hline PCT & product consistency test \\
\hline psi & pounds per square inch \\
\hline RWS & rapid water-soluble (test) \\
\hline SLZ & salt-loaded zeolite \\
\hline TTT & time-temperature-transformation (diagram) \\
\hline WASRD & Waste Acceptance System Requirements Document \\
\hline XRD & X-ray diffraction \\
\hline
\end{tabular}




\title{
Effects of Heat Treatment and Formulation on the Phase Composition and Chemical Durability of the EBR-II Ceramic Waste Form
}

\author{
W.L. Ebert ${ }^{1}$, N.L. Dietz ${ }^{1}$, and D.E. Janney ${ }^{2,3}$
}

\begin{abstract}
High-level radioactive waste salts generated during the electrometallurgical treatment of spent sodium-bonded nuclear fuel from the Experimental Breeder Reactor-II will be immobilized in a ceramic waste form (CWF). Tests are being conducted to evaluate the suitability of the CWF for disposal in the planned federal high-level radioactive waste repository at Yucca Mountain. In this report, the results of laboratory tests and analyses conducted to address product consistency and thermal stability issues called out in waste acceptance requirements are presented. The tests measure the impacts of (1) variations in the amounts of salt and binder glass used to make the CWF and (2) heat treatments on the phase composition and chemical durability of the waste form. A series of CWF materials was made to span the ranges of salt and glass contents that could be used during processing: between 5.0 and 15 mass $\%$ salt loaded into the zeolite (the nominal salt loading is $10.7 \%$, and the process control range is 10.6 to 11.2 mass\%), and between 20 and 30 mass\% binder glass mixed with the salt-loaded zeolite (the nominal glass content is $25 \%$ and the process control range is 20 to 30 mass $\%$ ). In another series of tests, samples of two CWF products made with the nominal salt and glass contents were reheated to measure the impact on the phase composition and durability: long-term heat treatments were conducted at 400 and $500{ }^{\circ} \mathrm{C}$ for durations of 1 week, 4 weeks, 3 months, 6 months, and 1 year; short-term heat treatments were conducted at $600,700,800$, and $850^{\circ} \mathrm{C}$ for durations of $4,28,52$, and 100 hours. All of the CWF products that were made with different amounts of salt, zeolite, and glass and all of the heat-treated CWF samples were analyzed with powder X-ray diffraction to measure changes in phase compositions and subjected to 7-day product consistency tests to measure changes in the chemical durability. The salt loading had the greatest impact on phase composition and durability. A relatively large amount of nepheline, $\mathrm{Na}_{4}\left(\mathrm{AlSiO}_{4}\right)_{4}$, was formed in the material made with 5.0 mass\% salt loading, which was also the least durable of the materials that were tested. Nepheline was not detected in materials made with salt-loaded zeolites containing 15 or 20 mass $\%$ salt. Conversely, halite was not detected with XRD in materials made with 5.0 or 7.5 mass\% salt loading, but similar amounts of halite were measured in the other CWF materials. The sodalite contents of all materials were similar. The halite content in the CWF source material used in the short-term heat-treatment study, which had the nominal salt and binder glass loadings, was determined to be about 1.3 mass $\%$ by standard addition analysis. Heat treatment had only a small effect on the phase composition: the amount of halite increased to as much as 3.7 mass \%, and trace amounts of nepheline were detected in samples treated at 800 and $850{ }^{\circ} \mathrm{C}$. The CWF samples treated at high temperatures had lower amounts of halite detected in the rapid water-soluble test. The releases of $\mathrm{B}, \mathrm{Na}$, and $\mathrm{Si}$ in the product consistency tests (PCTs) were not sensitive to the heat-treatment conditions. The PCT responses of all salt-loaded and heat-treated CWF materials were well below that of the Environmental Assessment (EA) glass.
\end{abstract}




\section{INTRODUCTION}

A ceramic waste form (CWF) has been developed at Argonne National Laboratory (ANL) to immobilize waste salts generated during the electrometallurgical treatment of spent sodiumbonded nuclear fuel from the Experimental Breeder Reactor (EBR)-II. Laboratory tests are being conducted to evaluate the physical, chemical, and radiological properties of CWF materials to support their acceptance for disposal at the planned federal high-level radioactive waste repository to be constructed at Yucca Mountain, Nevada. The CWF is considered by the U.S. Department of Energy (DOE) to be high-level radioactive waste (HLW), and the acceptance requirements for vitrified HLW are being used as guidance for the laboratory testing program. This report provides the results of laboratory tests that were conducted to address two informational needs identified in the DOE Office of Civilian Radioactive Waste Management Waste Acceptance System Requirements Document (WASRD) for vitrified HLW that are relevant to the CWF:

- Time-Temperature-Transformation diagrams for the vitrified HLW and identification of temperature limits (if any) necessary to preserve the properties of the vitrified HLW.

- Identification of the method to be used to assure consistency of production batches.

(DOE 2002, Section 5.4.1). The same product consistency test (PCT) method that was developed to monitor the consistency of HLW glasses has been shown to be suitable for measuring the consistency of CWF materials (Ebert et al. 2002a, Ebert et al. 2002b).

This report discusses two series of tests: tests that were conducted to provide information needed to evaluate the thermal stability of the phase assemblage and construct a TimeTemperature-Transformation (TTT) diagram, and tests that were conducted to evaluate the effect of CWF composition on phase composition and durability. Samples from both test series were analyzed with powder X-ray diffraction (XRD) to measure the relative amounts of crystalline phases in the CWF, and subjected to 7-day PCTs to measure the chemical durability.

The thermal stability tests were conducted with two nonradioactive reference CWF materials that had been made with the nominal production values of 25 mass $\%$ binder glass and 75 mass $\%$ zeolite $4 \mathrm{~A}$ containing 10.7 mass\% occluded salt. Both CWF materials used in the tests were made by pressureless consolidation (PC) at $915{ }^{\circ} \mathrm{C}$ for 16 hours, then allowed to cool in air. Cylindrical samples prepared from cores cut from one source sample were reheated at temperatures of $600,700,800$, or $850^{\circ} \mathrm{C}$ for durations of $4,28,52$, or 100 hours, then slowly cooled. Samples from previous heat treatments at 400 and $500{ }^{\circ} \mathrm{C}$ for durations up to 1 year were also analyzed. The heat-treated samples were crushed and analyzed with XRD to measure the phase compositions and subjected to 7-day PCTs to determine if the heat treatments and changes in phase composition affected the chemical durability. The CWF materials that were used to evaluate the effects of heat-treatment are referred to as "heat-treated CWF materials."

Previous scoping tests had shown that the PCT response (the amount of B released) is sensitive to differences in the relative amounts of salt-loaded zeolite (SLZ) and binder glass used to make CWF materials for glass contents between 25 and 45 mass\% (Lewis et al. 2002), although the 
difference between materials made with 25 and 30 mass $\%$ was small. The tests discussed in this report provide a more thorough measure of the effects of composition by studying CWF materials that span ranges of salt and glass loadings. Differences in the phase compositions (primarily the amounts of halite and nepheline formed) in CWF materials made with different amounts of salt and glass are also measured and related to the PCT responses.

A suite of materials were made using 9 different proportions of salt, zeolite, and binder glass to measure the effect of CWF composition on phase composition and chemical durability. Materials were made by consolidating zeolite that was loaded with between 5.0 and 15 mass\% salt mixed with between 20 and 30 mass $\%$ binder glass. The ranges of salt, zeolite, and binder glass contents selected for testing were based on the process control ranges established for CWF materials made using a hot isostatic press (HIP) during process demonstration (Goff et al. 1999). Control limits have not yet been established for the PC process. For the purposes of this report, the control limits for CWF made using the PC process (PC CWF) are presumed to be the same as those for HIP processing. It is possible that the limits for the PC process may be relaxed relative to the limits for HIP processing based, in part, on the results of these tests. The target salt loading is 10.7 mass $\%$, and the process control range is 10.6 to 11.2 mass $\%$. The target glass content is 25 mass \%, and the process control range is 20 to 30 mass \%. Thus, the materials used in testing, which are referred to as "salt-loaded CWF materials," were made with proportions of salt, zeolite, and glass that are either within or slightly outside the process control ranges with the intention of evaluating waste forms that could result from a possible process upset, such as the occlusion of too little or too much salt. The thermal stability tests represent waste forms with the nominal composition that were heated beyond the control range.

Samples of the salt-loaded CWF materials were analyzed with XRD to measure the effects of the salt and glass loadings on the phase composition, and other samples were subjected to triplicate 7-day PCTs to measure the effects of composition on the chemical durability. The heat-treated CWF samples were also analyzed with XRD and subjected to 7-day PCTs. Use of the 7-day PCT has been recommended for monitoring the consistency of CWF products. These results can also be interpreted as a measure of the sensitivity of the 7-day PCT to changes in the CWF chemical and phase composition due to the salt and glass loadings or heating histories. The results of tests and analyses with the salt-loaded CWF and heat-treated CWF samples are presented separately. 


\section{EFFECTS OF SALT LOADING AND GLASS LOADING}

\subsection{PRODUCTION OF SALT-LOADED CWF PRODUCTS}

The salt-loaded CWF materials were prepared at the former ANL-West laboratory (which is now part of the Idaho National Laboratory) and shipped to ANL for testing. The materials were made using different amounts of the same three starting materials: dehydrated zeolite $4 \mathrm{~A}$, simulated 300 driver salt, and glass frit. Prescribed amounts of dehydrated zeolite and crushed salt were first hot-mixed in a laboratory-scale V-mixer to occlude the salt into the zeolite structure. The salt-loaded zeolite (SLZ) was allowed to cool, and then the appropriate amount of binder glass was added and mixed with the SLZ in the V-mixer. The processing range of glass/SLZ mixtures is $20 \%-30 \%$ glass by mass, with a target glass loading of $25 \%$ (Goff et al. 1999, p. 21 ). The target proportions of each starting material for each of the waste forms made for this study and the masses of dried zeolite, salt, and binder glass required to make 900 grams of each material are given in Table 1. This would provide enough mixed material to make two 400-g CWF products, if necessary. (Note: The term "CWF product" is used to identify a particular piece that was made. More than one CWF product was made from some mixtures.)

\subsubsection{Components}

\section{Zeolite}

Large amounts of the zeolite used to make CWF had been purchased from UOP (Des Plaines, IL) in a granular form in which fine-grained zeolite $4 \mathrm{~A}$ (about $5 \mu \mathrm{m}$ average particle diameter) is aggregated with a clay binder. The zeolite is size-reduced to about $-60+325$ mesh (smaller than 60 mesh and larger than 325 mesh) before use to facilitate processing (e.g., transferring to the Vmixer and mixing with the binder glass). Zeolite received from the vendor can have a water content in excess of $20 \%$ and is routinely dried to a water content $<1 \%$ prior to mixing with salt. The drying is controlled so that the zeolite retains a small amount of water (e.g., $0.1 \%$ ), which is required to maintain the cage structure. A sample of the dried zeolite from each batch that is dried is rehydrated before use to be sure the cage structure was not damaged during the drying step; the zeolite must rehydrate to at least 18\% (Goff et al. 1999, p. 18). Two batches of dried zeolite were prepared for production of the salt-loaded CWF materials. The first batch (referred to as MPE-1) was dried in May 2004. It was transferred from the dryer into several 1-liter polyethylene bottles that were placed in a glovebox having an argon environment. The zeolite was kept in a dry environment because the moisture content of the zeolite affects its capacity for occluding salt. Moisture analyses of zeolite samples collected when batch MPE-1 was unloaded from the dryer indicated a moisture content of about $0.2 \%$. The zeolite is very hygroscopic and takes up even very small amounts of residual moisture from the glovebox atmosphere. After being dried and placed in the glovebox in May, the moisture contents of zeolites taken from two of the bottles were measured to be $0.3 \%$ and $0.9 \%$. Rehydration experiments conducted with zeolite prepared for use in making the salt-loaded CWF materials for this study resulted in a moisture content (as determined by Karl Fischer titration) of 17\% after being contacted by moist air for about 27 hours. Although this is slightly less than the required extent of rehydration, moisture analysis of $\mathrm{Li}_{2} \mathrm{SO}_{4} \cdot \mathrm{H}_{2} \mathrm{O}$ by Karl Fischer titration as a check standard commonly results in moisture contents that are about $1 \%$ lower than what is expected from stoichiometry. The 
moisture contents measured for the zeolites may be similarly biased low. Direct measurements of water uptake by mass indicated that more than $18 \%$ water was taken up, and the zeolite was deemed acceptable for use.

The dried zeolite taken from all bottles of MPE-1 had numerous lumps up to several millimeters in diameter. These usually broke up when the zeolite was transferred between containers by pouring through a funnel. These lumps did not appear to be localized near the top of the zeolite or at the bottle walls. Other lumps with diameters up to $1 \mathrm{~cm}$ formed and broke up while the zeolite was being mechanically sieved during size characterization studies.

A second batch of about $14 \mathrm{~kg}$ ground zeolite (referred to as MPE-070904) was prepared and dried in late October 2004. It was transferred to several 1-liter polyethylene bottles labeled "MPE-070904 \#1, \#2, \#3, etc.," and placed in an argon-environment glovebox. Analysis of zeolite taken from the top of bottle MPE-070904 \#5 on November 1, 2004, showed a moisture content of $0.2 \%$. Zeolite from this batch was only used to make CWF product S3E. Rehydration experiments conducted with zeolite taken from the same bottle showed a moisture content (as determined by Karl Fischer titration) of $18 \%$ after being contacted by moist air for about one week.

A previous study showed no discernable differences in the microstructure or chemical durability of CWF materials made using zeolites having water contents of 0.15 and $3.5 \%$ (Morss et al. 2002). One minor difference is that some of the oxide inclusion phases appeared "fuzzier" in CWF materials made with zeolite having less water. This probably reflected small differences in the physical separation of the submicrometer-sized inclusion phases within the binder glass. Although the water content was not measured prior to processing the CWF materials, the range of water contents of zeolite taken from different bottles and at different times is presumed to be small and to have no effect on the phase composition or durability.

\section{Salt}

All of the salt in the simulated CWF was from the same source that was prepared at ANL and shipped to ANL-West. Table 2 provides the nominal composition of simulated 300 driver salt (Goff et al. 1999, Table 5) and the as-batched composition of the salt that was provided to make the salt-loaded CWF materials. The nominal composition provides a nonradioactive surrogate salt representing the waste salt composition after processing 300 driver assemblies. This salt composition has been used for almost all of the CWF materials used in the testing program. A mixture of the appropriate amounts of reagent-grade chemicals were mixed then melted to homogenize. The resulting salt was mechanically ground and sized before being occluded in the zeolite. Separate batches of salt were ground to make the SLZ used for the first two waste forms (CWF S1 batch 1 and CWF S2 batch 1). Because it was thought that the exact size distribution of the salt particles might affect the efficiency of the mixing and salt occlusion steps, a single source of salt was prepared for the remaining CWF materials by consolidating several batches of ground salt in a 1-liter polyethylene bottle. The salt was mixed by manually rolling and inverting the bottle for several minutes; $870 \mathrm{~g}$ of salt was prepared and used to make the other $\mathrm{CWF}$ materials. The $\mathrm{Cl}$ contents measured in the CWF products (see Section 2.2.2) are in good agreement with the as-batched salt composition. 


\section{Binder Glass}

Crushed glass received from the vendor (PEMCO Corp., Baltimore, MD) was used without further preparation. The nominal size range of the glass is $-60+325$ mesh $(74-250 \mu \mathrm{m})$. All of the glass used to prepare the salt-loaded CWF materials was taken from the same source.

The zeolite, salt, and binder glass are all sized similarly to facilitate handling and processing of CWF materials. Table 3 gives the measured particle-size distribution of the zeolite and glass used to make the salt-loaded CWF materials.

\subsubsection{Processing}

Processing the starting materials into waste forms involved three steps: (1) preparing the SLZ by occluding the salt in the zeolite, (2) mechanically mixing the glass frit with the SLZ, and (3) consolidating the powdered mixtures into individual products. During the process-development phase of the EBR-II waste treatment project, mixtures of SLZ and binder glass were consolidated using a hot isostatic press (HIP) operated at $850-900^{\circ} \mathrm{C}$ and $14,500-25,000$ psi. The baseline consolidation process was changed from HIPing to pressureless consolidation (PC) during the inventory-reduction phase of the project to increase the throughput (Federal Register 2000). Although the PC process is essentially remelting of the binder glass, it is referred to as pressureless consolidation within the project to distinguish it from the HIP process. When heated above about $800^{\circ} \mathrm{C}$, the SLZ converts stoichiometrically to the mineral sodalite according to the reaction

$$
\underset{\mathrm{SLZ}}{\mathrm{Na}_{12}\left(\mathrm{AlSiO}_{4}\right)_{12} \bullet 4 \mathrm{NaCl}} \rightarrow \underset{\text { sodalite }}{2 \underset{\mathrm{Na}_{8}\left(\mathrm{AlSiO}_{4}\right)_{6} \mathrm{Cl}_{2}}{\rightarrow}}
$$

The fate of the clay binder used to aggregate the zeolite during consolidation is not known. (The identity and composition of the clay binder are proprietary.) It may dissolve in the binder glass, convert to nepheline or some other phase, or remain as a clay inclusion phase. Note that because a substoichiometric amount of $\mathrm{NaCl}$ will be occluded in the zeolite when processing the $\mathrm{CWF}$, there will be a slight excess of zeolite, which will result in the formation of a small amount of nepheline $\mathrm{Na}_{4}\left(\mathrm{AlSiO}_{4}\right)_{4}$. This is discussed in Section 2.2.3. The separate processing steps for making the CWF materials are discussed below, and the processing data are summarized in Table 4.

\section{Salt Occlusion}

Salt occlusion was done by placing the appropriate amounts of zeolite and salt in a laboratoryscale $\mathrm{V}$-mixer at room temperature, and then heating to $500-525^{\circ} \mathrm{C}$ as the $\mathrm{V}$-mixer was rotated at a nominal rate of $30 \mathrm{rpm}$. The heating profile was controlled by one of two programs. In program 1, the temperature was raised to a nominal temperature of $500{ }^{\circ} \mathrm{C}$ at a rate of 4 degrees per minute, although the process-control thermocouple indicated that the maximum temperature was typically $\sim 490^{\circ} \mathrm{C}$. Zeolite processed with $\mathrm{V}$-mixer program 1 generally had numerous hard lumps and high free-chloride values (see Appendix) that sometimes varied significantly for samples taken from the same batch of SLZ. In program 2, the V-mixer temperatures was ramped to a maximum of $515-523{ }^{\circ} \mathrm{C}$, as measured by the process-control thermocouple, at a rate of 4 
degrees per minute. Use of program 2 resulted in SLZ with lower free-chloride values that were more consistent for replicate samples from the same batch; however, salt-occluded MPE-1 zeolite also had large (several millimeters across) hard lumps. Similar lumps formed in previously-made SLZs were determined to consist of cores of salt coated with a layer of zeolite, and it is assumed that similar lumps are formed in the present case. The lumps were screened out of the SLZs used to make products S1B and S3B, but left in the SLZs used to make the other products. The formation of lumps of salt lowers the salt loading in the remaining zeolite.

After the V-mixer had reached its maximum temperature, it was maintained at that temperature for about 20-24 hours. The heater was turned off, and the SLZ was allowed to cool in the Vmixer. Rotation continued for about 3-4 hours more while the SLZ cooled. The duration that each batch of SLZ was at the maximum temperature, the length of time the V-mixer was rotated after the heater was turned off, and the SLZ temperature when rotation was stopped are listed in Table 4. The masses of salt, zeolite, and binder glass used to make each material and the resulting mass fractions in the CWF are also listed in Table 4.

Before the binder glass was added, three $0.5-1.5 \mathrm{~g}$ samples were taken from each batch of SLZ for free-chloride analyses. The V-mixer was rotated at $30 \mathrm{rpm}$ for approximately 1 minute before collection of each sample. (One exception was CWF S3 batch 3, for which the saltoccluded zeolite was unloaded from the V-mixer into a 1-L polyethylene bottle and shaken vigorously between samplings.) The free-chloride analysis is a hold point used during processing to measure the effectiveness of the salt-occlusion step. It involves immersing a known mass of SLZ in a mass of demineralized water that is 60 times the mass of SLZ at room temperature for 60 seconds to dissolve salt that was not occluded in the zeolite. The solution is then passed through a $0.45-\mu \mathrm{m}$ pore size filter into a bottle and analyzed for $\mathrm{Cl}^{-}$with ion chromatography. The measured $\mathrm{Cl}^{-}$concentration is used to calculate the percentage of salt that was not occluded in the zeolite, which is referred to as free chloride, as

$$
\% \text { free chloride }=100 \times \frac{\text { solution volume, } \mathrm{mL} \times\left[\mathrm{Cl}^{-}\right], \mathrm{g} / \mathrm{mL}}{\text { mass } S L Z, g}
$$

The target and process control limits for the free-chloride content of occluded waste salt are 0.05 and $0.5 \%$, respectively (Goff et al. 1999, p. 19). 


\section{Mixing SLZ and Binder Glass}

After the SLZ had cooled to room temperature and samples had been collected for free-chloride analysis, a measured amount of glass frit was added to the V-mixer. The V-mixer was then rotated at a nominal rate of $30 \mathrm{rpm}$ (at room temperature) to mix the glass and SLZ. The mixing times for the individual batches are given in Table 4 .

\section{Consolidation}

Approximately 400-g charges of mixed SLZ and glass were used to make each CWF product. The mixture was poured into a clean $600-\mathrm{mL}$ stainless steel beaker, and a stainless steel disk was placed on top of the mixture. A plug weighing approximately $1.5 \mathrm{~kg}$ was placed on top of the disk. The disk and plug are used to help densify the CWF as it consolidates during processing. A similar plunger arrangement will be used for actual CWF waste forms. Pressureless consolidation was done in a Thermcraft ${ }^{\circledR}$ crucible furnace that was heated from room temperature at a rate of $10^{\circ} \mathrm{C}$ per minute to a maximum temperature of $916^{\circ} \mathrm{C}$, and then held at that temperature for an additional 16 hours. The furnace was then turned off, and the waste form allowed to cool while still in the furnace. Argon gas was flowed through the furnace at a rate of $\sim 2$ standard cubic feet per hour during the consolidation and cooling steps. Additional information regarding their preparation and photographs of the CWF products are included in the Appendix. Each of the CWF products was broken into a few large pieces; some of the pieces were shipped to ANL for testing and analysis. Other pieces were retained at ANL-West (now INL).

\subsubsection{As-batched CWF and SLZ Compositions}

The gross compositions of the CWF materials calculated from the masses of salt, zeolite, and binder glass used to make them are given in Table 5. The calculation does not take into account the small amount of SLZ removed for free-chloride analyses. Note that products S1B and S3B were made with SLZ that had been screened to remove hard lumps, whereas products S1A and S3A were made with SLZ that was not screened. The nominal compositions of the salt, zeolite, and binder glass used in the calculations were measured previously (Lewis et al. 2002, Table 3). The number of chloride ions per zeolite unit cell was calculated using the nominal $\mathrm{Cl}^{-}$content of the salt $(59.5 \%)$ and formula weight of fully dehydrated zeolite, $\left(\mathrm{NaAlSiO}_{4}\right)_{12}(1704 \mathrm{~g})$ :

$$
\mathrm{Cl}^{-} \text {per unit cell zeolite }=\frac{\text { mass salt, } \mathrm{g} \times\left(0.595 \mathrm{~g} \mathrm{Cl}^{-} / \mathrm{g} \text { salt }\right) \times\left(1 \mathrm{Cl}^{-} \text {ion } / 35.45 \mathrm{~g} \mathrm{Cl}\right)}{\text { mass zeolite, } \mathrm{g} \times(1 \text { unit cell } / 1704 \mathrm{~g} \text { zeolite })}
$$

The small water content of the zeolite $(<1$ mass $\%)$ is ignored in the calculation. The calculated numbers of $\mathrm{Cl}^{-}$ions per unit cell zeolite for the different CWF products are included in Table 5. Actual CWF waste forms will be formulated to be slightly substoichiometric in $\mathrm{Cl}^{-}$(i.e., to have less than $4 \mathrm{Cl}^{-}$per unit cell zeolite): the production range is 3.4 to $3.6 \mathrm{Cl}^{-}$per formula. (This corresponds to 10.6 to 11.2 mass\% salt in the SLZ.) The contents of products S4A and S5B are greater than $4 \mathrm{Cl}^{-}$per unit cell zeolite, and represent waste salt contents exceeding the processing specifications. The salt contents of products $\mathrm{S} 1 \mathrm{~A}, \mathrm{~S} 1 \mathrm{~B}$, and $\mathrm{S} 2 \mathrm{C}$ are lower than the processing specifications. The $\mathrm{Cl}^{-}$contents of the other CWF products are within the production range. 


\subsection{ANALYSIS OF SALT-LOADED CWF PRODUCTS}

\subsubsection{Preparation of Salt-Loaded CWF Test Samples}

Representative samples were prepared from the provided CWF products for testing and analysis as follows. The large pieces of CWF were first fractured to generate marble-sized pieces. This was done by placing chunks of material in two plastic bags, laying the bags on an aluminum plate, and then striking the bags with a hammer. All of the material was placed in a beaker and then poured in a pile on a sheet of paper. The material was divided into four roughly equal fractions (cut 1), and one fraction was selected at random for further processing. The other three fractions were placed in a clean plastic bag and archived. The cut 1 fractions contained about 40 $\mathrm{g}$ of material. These were further size-reduced using a laboratory mill fitted with a tungsten blade. Each material was crushed briefly in the mill, and all the material was collected in a beaker. The material was then poured into a pile on a piece of paper and divided into two roughly equal fractions (cut 2). One of the fractions was selected randomly for further processing, and the other fraction was placed in a clean plastic bag and archived. This resulted in about $20 \mathrm{~g}$ of each material from cut 2 for further processing. A small amount of material (about $5 \mathrm{~g}$ ) was poured into the laboratory mill and further crushed. The crushed material was passed through a series of $80,100,200$, and 325 mesh sieves using a laboratory sifter. Material that did not pass through the 80 mesh sieve was placed back into the mill along with additional material from cut 2 . Both the $-100+200$ and $-200+325$ mesh size fractions were retained. The fine material that passed through the 325 mesh sieve was discarded. The cut 2 materials were crushed and sieved until at least $5 \mathrm{~g}$ of each material in the $-100+200$ mesh size fraction was collected. The remaining coarse materials and the $-200+325$ mesh size fractions were archived. The materials prepared for testing and analysis are expected to be representative of each saltloaded CWF product, including regions that may not have been completely transformed from zeolite to sodalite. Only enough of the salt-loaded CWF materials S1B and S3B were prepared in the $-200+325$ mesh size fraction to perform XRD analyses to determine if removing lumps of SLZ prior to processing affected the phase composition of the final product. These are otherwise presumed to be identical to the products S1A and S3A that were made with the same mixture of SLZ and binder glass.

\subsubsection{Compositional Analysis of Salt-Loaded CWF Products}

Approximately 50-mg samples of the $-100+200$ mesh size fractions were dissolved in a mixture of $2 \mathrm{~mL} \mathrm{HCl}+1 \mathrm{~mL} \mathrm{HNO}_{3}+0.5 \mathrm{~mL} \mathrm{HF}+5 \mathrm{~mL} \mathrm{H}_{2} \mathrm{O}$ in a sealed stainless steel vessel at $140{ }^{\circ} \mathrm{C}$. The resulting solutions were diluted to $50.0 \mathrm{~mL}$ total and analyzed with inductively coupled plasma-mass spectrometry (ICP-MS). A sample of low-activity reference material (LRM) glass was dissolved in parallel with the CWF materials as a standard. The LRM glass was developed as a standard material for testing low-activity waste glasses, and the LRM composition was measured previously as part of an interlaboratory study (Ebert and Wolf 2000). It was used here to validate the compositional analyses of the salt-loaded CWF materials.

The mass of each CWF material that was dissolved and the measured concentrations are summarized in Table 6. The mass fraction of each component was calculated as 


$$
f(i)=\frac{\text { measured concentration } i, \mathrm{mg} / \mathrm{L}, \times 0.050 \mathrm{~L}}{1000 \mathrm{mg} / \mathrm{g} \times \text { mass } C W F \text { dissolved }, \mathrm{g}}
$$

where $f(i)$ is the mass fraction of element $i$ and the volume of all solutions was $0.050 \mathrm{~L}(50.00$ $\mathrm{mL}$ ). The $\mathrm{B}$ and $\mathrm{Cl}$ contents reflect the relative amounts of glass and salt, respectively, in the different materials. Note the similarities in $f(\mathrm{~B})$ for products S1A, S2B, S3A, S3C, S3E, S4A, and $\mathrm{S} 5 \mathrm{~B}$, in which the glass content is constant, and the increase in $f(\mathrm{~B})$ as the glass content increases as $\mathrm{G} 1<\mathrm{G} 2<\mathrm{S} 3 \mathrm{~A}, \mathrm{~S} 3 \mathrm{~B}, \mathrm{~S} 3 \mathrm{C}<\mathrm{G} 4<\mathrm{G} 5$. The values of $f(\mathrm{Cl})$ increase as the salt loading in the SLZ in the CWF material increases, as $\mathrm{S} 1 \mathrm{~A}<\mathrm{S} 2 \mathrm{~B}<\mathrm{S} 3 \mathrm{~A}, \mathrm{~S} 3 \mathrm{C}, \mathrm{S} 3 \mathrm{E}<\mathrm{S} 4 \mathrm{~A}<\mathrm{S} 5 \mathrm{~B}$, but decrease as the amount of SLZ decreases, as G1A $>$ G2A $>$ S3A, S3C, S3E $>$ G4A $>$ G5A. Most other components are present in both the zeolite and glass, and their contents do not reflect changes in the glass and salt loadings, as obviously as do B and $\mathrm{Cl}$.

The elemental mass fractions of LRM glass were calculated from the mean values of the oxide mass fractions reported in Table 4 of Ebert and Wolf (2000). The differences in the major components are: $4.5 \%$ for $\mathrm{Al}, 6.4 \%$ for $\mathrm{B}, 1.9 \%$ for $\mathrm{Na}$, and $10.1 \%$ for $\mathrm{Si}$. The estimated reproducibilities for composition analysis of several elements in LRM glass (Table 6 of Ebert and Wolf 2000) are given in Table 5 in the rows labeled "LRM std." The contents of quantified elements measured in the present analysis of LRM glass are within the expected uncertainty ranges.

The compositions of products S3A, S3C, and S3E indicate the repeatability of making materials with the same target composition, and the compositions of dissolved solution S4A and S4A dup. indicate the analytical repeatability. The compositional similarity of Products S3A, S3C, and S3E can be compared with the reproducibility of measuring the LRM glass composition by calculating and comparing "percent relative uncertainty" values analogous to the percent relative standard deviation. For example, the estimated reproducibility for the Al content of LRM glass is $5.03 \pm 0.53$, and the percent relative uncertainty is $100 \times(0.53 / 5.03)=10.5 \%$. Values for other major components in LRM glass are $12.3 \%$ for $\mathrm{B}, 16.9 \%$ for $\mathrm{Na}$, and $7.5 \%$ for $\mathrm{Si}$. The relative uncertainties in the compositions of the replicate samples (products S3A, S3C, and S3E) are $7.2 \%$ for $\mathrm{Al}, 0.8 \%$ for $\mathrm{B}, 6.3 \%$ for $\mathrm{Na}$, and $2.1 \%$ for Si. The variations in the results of duplicate analyses of product S4A (S4A and S4A dup. in Table 5) are $2.2 \%$ for A1, 2.0\% for B, $4.1 \%$ for $\mathrm{Na}$, and $2.0 \%$ for $\mathrm{Si}$. The results for analysis of replicate materials and the duplicate analyses are within the percent relative uncertainties measured for LRM glass in the interlaboratory study. 


\subsubsection{Density Analysis of Salt-Loaded CWF Products}

The densities of CWF materials made by the pressureless consolidation method (sometimes indicated as "PC CWF") are typically about $2000 \mathrm{~kg} / \mathrm{m}^{3}$, compared with the theoretical density of about $2300 \mathrm{~kg} / \mathrm{m}^{3}$. PC CWF materials made for laboratory testing typically have about 10 to $15 \%$ closed porosity with pore sizes as large as about $100 \mu \mathrm{m}$. However, the porosity of the crushed PC CWF materials used for XRD analyses and PCTs is expected to be much lower because most of the pores are eliminated when the material is crushed. The densities of the CWF materials recovered from the PCTs were measured by water displacement. Each dried material was poured into a $50-\mathrm{mL}$ volumetric flask and weighed. The flask was filled with demineralized water to slightly below the volumetric line and slowly rotated to be sure all of the CWF was wetted and to free any adhering air bubbles. The volumetric flask was placed in a $40{ }^{\circ} \mathrm{C}$ oven for about 1 hour. The flask was then removed from the oven, and demineralized water was added until the meniscus reached the volumetric line, and the flask was weighed. (The slightly higher density of the small amount of room-temperature water that was added was neglected.) The water and glass were then removed from the flask, and the flask was rinsed several times with water, then filled with demineralized water to near the volumetric line and placed in a $40{ }^{\circ} \mathrm{C}$ oven overnight. The flask was then removed from the oven, and demineralized water was added until the meniscus reached the volumetric line, and the flask was weighed. The mass of water required to fill the flask to the line was used to verify the volume of the flask based on the density of air-saturated water at $40{ }^{\circ} \mathrm{C}\left(0.99224 \mathrm{~g} / \mathrm{cm}^{3}\right)$.

The total volume of water added to the flask for measurements with glass was calculated based on the measured mass of water that was required to fill the flask to the volumetric line when the CWF was present. The mass of added water was calculated based on its mass and density, and the volume of the CWF was calculated by the difference between the calculated volume of water and the measured volume of the flask. The density was calculated as the ratio of the measured mass of glass added to the flask and the calculated volume of CWF. The densities measured for the different CWF materials were then used to calculate the specific surface areas of the -100 +200 mesh size fractions by modeling the particles as spheres having a diameter equal to the average sieve opening. The specific surface area, $S_{s p}$, is calculated as

$$
S_{s p}=\frac{6}{\rho \times d}
$$

where $\rho$ is the density and $d$ is the particle diameter. The mesh openings of 100 and 200 mesh sieves are 150 and $75 \mu \mathrm{m}$, respectively, and the modeled particle diameter is $112.5 \mu \mathrm{m}$. The results of the density measurements and specific area calculations for each material are given in Table 7. The mean and standard deviation of the specific surface areas of the nine different saltloaded CWF materials is $0.0229 \pm 0.0010 \mathrm{~m}^{2} / \mathrm{g}$. The densities do not correlate with either the salt or glass contents, and the differences are attributed to uncertainties in the measurements. Therefore, the mean specific surface area of $0.023 \mathrm{~m}^{2} / \mathrm{g}$ was used for all materials. The density measured for the CWF material used in the heat-treatment tests is included in the table as "no heat." The measured value of $0.0237 \mathrm{~m}^{2} / \mathrm{g}$ is within the range measured for the salt-loaded CWF materials, and the same specific surface area of $0.023 \mathrm{~m}^{2} / \mathrm{g}$ was also used for all heat-treated samples. 


\subsubsection{XRD of Salt-Loaded CWF Products}

Powder X-ray diffraction analysis (XRD) was performed using the $-200+325$ mesh size fraction material. Spectra were collected with a Rigaku D/max Rotatin Anode Diffractometer equipped with a vertical goniometer using $\mathrm{Cu} \mathrm{K}_{\alpha}$ radiation at $40 \mathrm{kV}$ and $100 \mathrm{~mA}$ using a nominal scan rate of 2.4 degrees/minute. The spectral peaks were matched with those from reference spectra of sodalite, halite, and nepheline based on the measured $d$-spacings and relative peak heights. The $d$-spacings and relative peak heights of the reference spectra used to identify peaks in both the salt-loaded and heat-treated CWF materials spectra are summarized in Table 8. The XRD spectra for the different salt-loaded CWF materials are shown in Figs. 1a-1m, and the $d$-spacings and relative peak heights and areas (both reported as percentages of the values of the sodalite $3.624 \AA$ peak) are summarized in Tables 9-12. Because sodalite remained the most abundant crystalline phase in all products, the sodalite peaks in the spectra of the salt-loaded CWF materials were used as internal references to help match the less intense peaks to those of nepheline or halite. The sodalite peaks in most spectra were shifted several hundredths of an Angstrom from those in the reference spectra, and similar shifts of neighboring peaks are assumed to occur. The observation that the peak shifts differed for different samples suggests that the shifts are due primarily to artifacts in the collection of the spectra. The peak shifts are discussed more thoroughly for spectra of heat-treated CWF samples in Section 3.2.2 because replicate analyses were conducted with the source CWF material.

The heights of the major peaks in the spectra of the salt-loaded CWF materials that were matched to the reference materials are summarized in Table 13. All peak heights are given relative to the sodalite $3.624 \AA$ peak, which is the most intense peak in all spectra. Note that the relative heights of various sodalite, halite, and nepheline peaks in the CWF materials do not match those given for the reference materials in all instances. For example, the sodalite peaks at $2.093 \AA$ are higher than the peaks at $6.280 \AA$ for most CWF products, whereas the height of the $6.280 \AA$ peak is twice that of the $2.093 \AA$ peak in the reference spectrum. This may be due to minor compositional differences between the sodalite formed in CWF and the reference material.

The peak areas were used to compare the relative amounts of halite, nepheline, and sodalite in the different salt-loaded CWF materials. These are summarized in Table 14. Although the peaks areas were not calibrated, they are used to provide a semiquantitative measure of the effect of salt and glass loading on the relative amounts of halite and nepheline that form. The relative areas of major halite, nepheline, and sodalite peaks in CWF materials made with various salt and binder glass loadings are plotted in Figs. 2a-2c. Materials S1A, S1B, and S2A contained comparatively large amounts of nepheline (Fig. 2c), but no detectable halite (Fig. 2a). The halite content increased slightly in CWF materials made with higher salt loadings. Products S3A, S3B, $\mathrm{S} 3 \mathrm{C}$, and $\mathrm{S} 3 \mathrm{E}$ provide a measure of the sensitivity of the $\mathrm{CWF}$ material to variations in processing. The four products were made to have the same salt and glass loadings, but there were slight variations in the how they were processed (see Table 4): products S3A, S3B, S3C, and S3E were made with different mixtures of SLZ and binder glass (but having the same proportions); product S3B was made with SLZ from which lumps were removed prior to processing; product $\mathrm{S} 3 \mathrm{E}$ was made with a different batch of zeolite than the other products. The areas of the halite peaks in the S4A spectrum are within the ranges measured for peaks in the 
S3A, S3B, S3C, and S3E spectra, but the peaks in the S5A spectrum are significantly higher (Fig. 2a). The areas of the sodalite peaks were insensitive to the salt content, although two of the three peaks being compared are highest in the spectrum of product S1A (Fig. 2b). The areas of the nepheline peaks decrease as the salt loading increases from 5\% to higher values (Fig. 2c).

The halite fraction was not correlated with the glass content of the salt-loaded CWF materials. Only a small amount of nepheline was formed in materials made with $10.7 \%$ salt in the SLZ, and similar amounts were formed with various glass contents (Fig. 2c). The spectrum of product G4A had the highest $3.844 \AA$ and $3.273 \AA$ nepheline peaks, but the $3.006 \AA$ peak was average. The areas of the sodalite peaks are not affected by the glass loading (Fig. 2b). The spectrum of product G1A has the greatest $6.28 \AA$ and $6.563 \AA$ sodalite peak areas, but the smallest $2.093 \AA$ peak area.

\subsubsection{PCT with Salt-Loaded CWF Products}

The product consistency test (PCT) was developed as a partial dissolution test to compare the relative chemical durabilities of waste glasses within a short test duration. The test was developed to be conducted with crushed glass to facilitate use of the method in a hot cell. The method calls for reacting crushed glass of a specific size fraction $(-100+200$ mesh) with demineralized water at a glass-to-water mass ratio of 0.1 at $90{ }^{\circ} \mathrm{C}$ for 7 days. The resulting solution is passed through a $0.45 \mu \mathrm{m}$ pore size filter and analyzed for soluble glass components, including $\mathrm{B}$, alkali metals, and $\mathrm{Si}$. The masses of these elements released to solution are normalized to the masses in the glass to allow direct comparison to releases from other glasses. Two variations of the PCT procedure have been standardized by the American Society for Testing and Materials as standard test method C 1285 (ASTM 2004). Method A is used specifically to measure the chemical durability of a glass (or glass-ceramic) for comparison to that of a benchmark glass under prescribed test conditions. Method B is used for testing under other conditions to study the dissolution behavior of the glass (or glass-ceramic). The PCT is a static test method.

Although the relative masses of glass and water are controlled in the PCT, the surface area of exposed glass will significantly affect the test response. The use of a specific size fraction ensures similar particle sizes, but glasses having different densities will have different specific surface areas, and the 1:10 mass ratio will result in different exposed surface areas. The mass of a glass component that is released into solution will depend on the product of the dissolution rate and the surface area, as well as its mass fraction in the glass. A reliable estimate of the surface area of crushed glass (or glass-ceramic) based on the size fraction requires that fines be removed from the crushed material.

The PCT can be applied to CWF materials and provides a measure of the simultaneous dissolution of halite, sodalite, and binder glass. In practice, halite is dissolved from the surface prior to the static dissolution step. The release during the tests is then due to dissolution of sodalite and the binder glass. Since B is only present in the binder glass, the releases of B and $\mathrm{Si}$ can be used to distinguish the dissolution of the binder glass and sodalite. 
The PCT procedure calls for washing the crushed glass with demineralized water and ethanol, and analyzing the wash solution if water-soluble phases are suspected to be present in the material being tested (ASTM 2004, see step 19.6.1). Halite exposed at the surface of the crushed CWF is assumed to dissolve immediately when contacted by water. Therefore, as part of applying the PCT to CWF materials, the solution generated by washing the crushed material with demineralized water is retained and analyzed to measure the amount of halite that dissolves during the water wash. For PCTs with CWF materials, the crushed materials are first washed several times with absolute ethanol to remove fines, and then washed once with demineralized water. The PCT calls for the glass to be washed with demineralized water first and then with ethanol. The water wash is used to monitor the amount of halite present in the waste form and is referred to as the "rapid water-soluble" (RWS) test. The order is reversed for CWF materials to exclude fines from the RWS test. The RWS test is conducted using an amount of demineralized water equal to 10 times the mass of CWF material being washed. In this way, the concentrations measured in the RWS text can be compared directly with the concentrations measured in the PCT, which is also conducted using an amount of water equal to 10 times the mass of crushed solid.

The $-100+200$ mesh size fraction material of each CWF product was washed with absolute ethanol to remove fines, without dissolving halite, before it was subjected to PCTs. The crushed materials were placed in $50-\mathrm{mL}$ beakers, and the masses determined. Fines were removed from the materials by adding absolute ethanol to the beaker and swirling to suspend the fines, and then decanting the ethanol into a waste container. This was repeated 5 times for each sample, after which no fines could be seen in the ethanol. The beakers with the ethanol-washed materials were placed in a $90{ }^{\circ} \mathrm{C}$ oven to dry.

One RWS test was conducted for each material. About $5 \mathrm{~g}$ of each CWF material was sized and washed with ethanol, which is enough to conduct three PCTs. The CWF materials were left in the same beakers used for the ethanol wash. The mass of ethanol-washed salt-loaded CWF material was measured after drying. The target mass of demineralized water used in the RWS test was 10 times the mass of CWF material. About $20 \mathrm{~mL}$ of water was added initially and swirled manually to ensure all the CWF material was wetted. Additional demineralized water was then added up to the target mass. The water was stirred briefly using a stainless steel spatula, then decanted into a syringe fitted with a $0.45-\mu \mathrm{m}$ pore size filter. The filtrate solution was collected in two bottles for replicate $\mathrm{Cl}^{-}$analysis with ion chromatography. About 2 minutes elapsed between the time water was first added to the CWF material, and the second aliquot of RWS solution was decanted into the syringe. The test data for the RWS tests with the saltloaded CWF materials are given in Table 15. 
The results of PCT and other corrosion tests are commonly presented in terms of normalized concentrations and normalized elemental mass losses to facilitate comparing the behaviors of different materials under slightly different test conditions. The normalized concentration $(N C)$ is calculated by dividing the concentration of an element in the test solution by the mass fraction of that element in the CWF material:

$$
N C(i)=\frac{C(i)-C^{\circ}(i)}{f(i)}
$$

where $C(i)$ is the concentration of element $i$ in the test solution, $C^{\circ}(i)$ is the background concentration of element $i$, and $f(i)$ is the mass fraction of element $i$ in the material. The background concentrations are generally measured in blank tests conducted in parallel with PCTs, so that $N C(i)$ represents only material released from the test material. The normalized elemental mass loss is calculated by dividing the concentration of an element in the test solution by the mass fraction of that element in the CWF material and by the surface area of the dissolving material:

$$
N L(i)=\frac{C(i)-C^{\circ}(i)}{S / V \times f(i)}
$$

where $S$ is the surface area of the material exposed in the test and $\mathrm{V}$ is the leachant volume.

When applying Eqs. 6 and 7 to CWF materials, the overall mass fraction of an element in the CWF material is used rather than the mass fractions in individual phases (see Table 6 for overall mass fractions of CWF components). In this way, the surface area that is calculated as the product of the CWF mass and specific surface area can be used to calculate the amounts of each element exposed at the surface. Of course, the concentrations measured in the test solutions represent the combined dissolution of all phases. This approach presumes that relative amounts of each phase exposed at the surface are the same in the fraction of that phase in the bulk. Previous studies showed that this is a valid assumption for the CWF materials because the domain sizes of the individual phases (e.g., less than about $100 \mu \mathrm{m}$ for the sodalite domains and less than about $10 \mu \mathrm{m}$ for the halite inclusions) are similar to or smaller than the size of the crushed particles, and the CWF does not preferentially fracture along phase boundaries or become fractionated during sizing (Ebert et al. 2002a). Note that the concentrations of $\mathrm{B}, \mathrm{Na}$, and $\mathrm{Si}$ in the blank tests were negligible compared to those in the test solutions (i.e., $<1 \%$ ), and background subtraction was neglected in the calculations of $N C(i)$ and $N L(i)$.

The RWS test results are summarized in Table 16 in terms of the measured concentrations and the normalized chloride mass loss. Values of $N L(\mathrm{Cl})$ are plotted in Fig. 3 for materials having different salt loadings and different glass loadings. The values of $N L(\mathrm{Cl})$ increase significantly as the salt content increases and decrease as the glass content increases: the ratio of the highest and lowest values of $N L(\mathrm{Cl})\left(11.5 \mathrm{gm}^{-2}\right.$ for product $\mathrm{G} 1 \mathrm{~A}$ and $0.0336 \mathrm{gm}^{-2}$ for product $\left.\mathrm{S} 1 \mathrm{~A}\right)$ is $342 x$.

Part of the difference in the RWS results for different CWF materials may be attributable to differences in extent of salt occlusion in the SLZs. The results of the free-chloride measurements 
made for the various SLZ mixtures used to make the different CWF materials are included in Table 16; these values are given as percentages (see Eq. 2). Figure 4 shows the results of three separate measurements of each SLZ used to make CWF materials. Although there are significant variations in the three $\mathrm{Cl}^{-}$measurements made for the SLZs used to make products $\mathrm{S} 1 \mathrm{~A}$ and S3A, and run 3 for product S5B is significantly higher than runs 1 and 2, the results for the other SLZ mixtures are similar. The range in results for products S1A and S3A may be an effect of the lumps observed in the SLZ (see Appendix A). Also, it is worth noting that the SLZ used to make product S3A was rotated in the V-mixer for more than 24 hours while it cooled to room temperature, whereas mixing of other SLZs occurred for only a few hours. However, this should not decrease the effectiveness of occluding the salt. No obvious trend in the free-chloride values with salt loading is revealed in Fig. 4, and, except for the scatter in the three measurements of S3A, the separate SLZ mixtures having a salt loading of $10.7 \%$ (SLZ batches 1 , 2 , and 3 for material $3 \mathrm{~A}$ ) give similar free-chloride values. Therefore, differences in the $N L(\mathrm{Cl})$ values for the RWS tests are probably not due to differences in the effectiveness of salt occlusion in the different SLZs. They are instead attributed to differences in the amounts of halite generated when the CWF materials were processed. Part of the decrease in $N L(\mathrm{Cl})$ as the glass content increases is due to the decrease in the amount of SLZ available to generate halite as the mixture is processed in going from product G1A (made with $80 \%$ SLZ) to product G5A (made with $70 \%$ SLZ).

Test data for the triplicate PCTs conducted with the different salt-loaded CWF materials are summarized in Table 17. This includes data regarding the amounts of CWF and water used in each test, the calculated surface area/solution volume ratio, the test vessel identification number, the total vessel masses at the initiation and termination of the test, the $\mathrm{pH}$ of the test solution at the end of the test (measured at room temperature), and data for the test solution collected for analysis. The test solutions were diluted with demineralized water and acidified with concentrated nitric acid prior to submission for analysis with ICP-MS. A dilution factor was calculated using the mass of solution collected and the masses of water and acid that were added as

$$
\text { dilution factor }=\frac{\text { mass test solution }+ \text { mass water }+ \text { mass } \mathrm{HNO}_{3}}{\text { mass test solution }}
$$

The measured concentrations were multiplied by the dilution factors to correct for the dilutions. Two blank tests were conducted with demineralized water in a test vessel placed in the oven along with the tests with CWF materials. The water recovered from the blank tests was acidified prior to analysis, but it was not filtered or diluted. The concentrations measured in the blank tests were to be used as background concentrations to calculate $N C(i)$ and $N L(i)$ (see Eqs. 6 and 7), but, as mentioned above, they were negligible compared to concentrations in the test solutions and ignored in the calculations.

The results of PCTs with the salt-loaded CWF materials are summarized in Table 18, which includes the dilution-corrected solution concentrations of $\mathrm{Al}, \mathrm{B}, \mathrm{Na}$, and $\mathrm{Si}$, and the normalized concentrations and normalized elemental mass losses based on the concentrations of $\mathrm{B}$, Na, and $\mathrm{Si}$. The releases of $\mathrm{Li}$ and $\mathrm{K}$ were not tracked because of the low $\mathrm{Li}$ content of the CWF materials (less than 0.6 mass\% Li) and because the Environmental Assessment (EA) glass used 
as a benchmark for the chemical durability of HLW glass does not contain K (see Section 4.4). (In addition, analysis of $\mathrm{K}$ using ICP-MS has high uncertainty due to the isobaric interference with the Ar carrier gas.) The Al concentration was measured, but the normalized concentrations and normalized mass losses were not calculated based on $\mathrm{Al}$ to evaluate durability.

The values of $N L(\mathrm{~B}), N L(\mathrm{Na})$, and $N L(\mathrm{Si})$ for the 7-day PCTs are plotted in Figs. $5 \mathrm{a}-5 \mathrm{c}$ for CWF products made with various salt and glass loadings. Values of $N L(\mathrm{~B})$ are significantly higher in the 3 tests conducted with product SA1, which was made with 5\% salt in the SLZ, but are similar in tests with other salt loadings (Fig. 5a). The values of $N L(\mathrm{Na})$ are similar for the various saltloaded CWF products (Fig. 5b), but the values of $N L(\mathrm{Si})$ decrease as the salt content increases (Fig. 5c). The values of $N L(\mathrm{~B})$ are not significantly affected by glass content of the CWF products, within the scatter in the results (Fig. 5a), but the values of $N L(\mathrm{Na})$ decrease slightly as the glass loading increases (Fig. 5b). The values of $N L(\mathrm{Si})$ are higher for the products made with $25 \%$ glass (Fig. 5 c) than for products made with either more or less glass. 


\section{EFFECTS OF HEAT TREATMENT}

The DOE WASRD requires that waste form producers provide Time-TemperatureTransformation (TTT) information to assure that neither unplanned heating during manufacture (e.g., due to a process upset) nor heating during transporting, storage, or disposal will adversely affect the durability of the high-level radioactive waste forms. Although the requirement addresses concerns regarding the devitrification of glass waste forms, the possible effects of heating on the durability of the CWF were evaluated to measure its thermal stability. To support qualification of the CWF, tests were conducted to identify any changes in the phase assemblage due to heat treatment at various temperatures and durations, including the relative amounts of each phase.

In contrast to standard borosilicate glass waste forms, which typically contain only about 1 volume $\%$ crystalline inclusion phases, the CWF contains about 75 volume $\%$ crystalline phases and 25 volume \% borosilicate binder glass. Despite the relatively low binder glass content, the chemical durability of the CWF under repository-relevant conditions depends strongly on the durability of the binder glass phase. In fact, the performance of the CWF is modeled based on the durability of the binder glass (Fanning et al. 2003). This is because the solutions contacting the CWF under disposal conditions are expected to be saturated with respect to sodalite. Changes in the glass composition that result from changes in the phase assemblage, such as the formation of new alumino-silicate phases, could affect glass durability. Previous work has shown that the dissolution of sodalite into the binder glass could enhance glass durability by increasing its aluminum and silicon content (Jeong et al. 2002, Section 3.6; Frank 2004). In contrast, an increase in the halite content could lower the durability of the CWF by either chemical or physical effects. That is, dissolution of halite inclusions increases the surface area of exposed binder glass.

Another potentially detrimental effect is the formation of nepheline. The formation of nepheline often reduces the durability of a borosilicate glass by consuming aluminum and silicon (Li et al. 1997). Small amounts of nepheline are known to form in CWF materials when zeolite in excess of that needed to react with the occluded salt to generate sodalite is present. Small amounts of nepheline were commonly detected in HIP CWF materials by XRD, but nepheline has not been detected in most PC CWF materials. These tests are expected to provide insight regarding the effect of heating on nepheline formation and the effect of nepheline on the durability of the binder glass in the CWF. Therefore, a key objective of this series of tests and the TTT diagram to be constructed was to determine changes in the halite and nepheline contents as the CWF material was heated. Insight into changes in the halite content was provided directly by XRD analysis of the heat-treated materials and indirectly by the RWS tests that were conducted as part of the PCT.

Samples from two series of heat-treatment studies were analyzed with XRD to measure the phase composition and provide data for constructing a TTT diagram. The first set of CWF samples had been heat-treated at $400{ }^{\circ} \mathrm{C}$ or $500{ }^{\circ} \mathrm{C}$ for durations between 1 week and 1 year previously; these are referred to as long-term heat-treated CWF samples. A second set of samples was heat-treated at $600,700,800$, or $850{ }^{\circ} \mathrm{C}$ for durations between 4 and 100 hours; these are referred to as shortterm heat-treated CWF samples. The short-term heat-treated CWF samples provide insight into 
the impact of exceeding processing parameters of time and temperature on the phase composition and durability. The long-term heat-treated CWF samples provide insight into the stability of waste forms during storage prior to emplacement in the repository. The phase stability of the heat-treated CWF samples is also pertinent to waste form behavior under a volcanic intrusion event in the repository.

\subsection{GENERATION OF HEAT-TREATED CWF SAMPLES}

\subsubsection{Preparation of CWF Source Materials}

The CWF source material used in the set of long-term heat treatments at 400 and $500{ }^{\circ} \mathrm{C}$ was prepared by pressureless consolidation with the nominal composition of 25 mass $\%$ binder glass and 75 mass $\%$ SLZ (batch 10090) that contained 10.71 mass\% salt (300 driver salt identified as "Putty 06/22/00") occluded in dehydrated zeolite (batch D10020) having the nominal $-120+325$ mesh sieve size. The SLZ is calculated to occlude $3.8 \mathrm{Cl}^{-}$per zeolite unit cell, and the measured free-salt concentration was $0.03 \%$. Four 20 -g CWF products were made from the mixture (product numbers PC10501, PC10601, PC10701, and PC10801) by heating at $915{ }^{\circ} \mathrm{C}$ for 16 hours, then cooling at about $5{ }^{\circ} \mathrm{C}$ per minute. The resulting $\mathrm{CWF}$ products were fractured into several pieces for use in the tests. The fragments were heated at 400 or $500{ }^{\circ} \mathrm{C}$ in laboratory ovens (in air) for durations up to 1 year. As a part of the original testing, samples were analyzed with XRD and subjected to static leach tests following the Materials Characterization Center test method number 1 (MCC-1). It was reported that no changes due to heat treatment were detected by X-ray diffraction and that the heat treatments did not affect the physical integrity of the CWF.

Pieces of the heat-treated CWF materials that had been potted in epoxy resin for SEM analyses were used for the current tests. The samples were recovered by cutting away most of the epoxy using a wafering blade with absolute ethanol as a lubricant. Previous microscopic analyses of CWF materials embedded in the same epoxy indicated that the epoxy fills pores at the surface, but does not penetrate into the CWF. The recovered CWF samples were first fractured manually with a hammer and then crushed using a laboratory mill. The crushed material was sieved with a mechanical sifter to isolate the $-100+200$ and $-200+325$ mesh size fractions. Small pieces of epoxy that had not been cut off the outer surfaces of the recovered samples but became separated from the CWF during crushing were removed from the crushed materials using forceps. Although it is likely that epoxy remained on the surfaces of a few grains in the sieved materials, this is not expected to affect the XRD results,, because the epoxy is X-ray amorphous, or the PCT results, because the epoxy doesn't contain significant amounts of $\mathrm{B}, \mathrm{Cl}, \mathrm{Na}$, or $\mathrm{Si}$. In addition, the small amounts of surface area that could be masked by epoxy are insignificant. Enough material was available to conduct XRD analysis and 1 PCT for each treatment condition, although less than the $1 \mathrm{~g}$ of material recommended in the PCT procedure was recovered for several CWF materials.

The CWF source material used in the short-term heat treatments between 600 and $850{ }^{\circ} \mathrm{C}$ was prepared with the nominal proportions of salt, zeolite, and binder glass with 75.0 mass $\%$ SLZ and 25.0 mass\% binder glass. The same SLZ (batch 10090) that was used to make the long-term samples was used for the short-term samples: 10.7 mass $\%$ simulated 300 driver salt "Putty 06/22/00" was occluded in dehydrated zeolite (batch D10020). A free-chloride concentration of 
$0.03 \%$ was measured for SLZ batch 10090. A 500-g PC CWF product was made under typical processing conditions: heating at $915^{\circ} \mathrm{C}$ for 16 hours, then cooling at about $5{ }^{\circ} \mathrm{C}$ per minute. The resulting CWF product is referred to as $\mathrm{PC} 10402$. Test samples were prepared by first coredrilling 1.5-cm-diameter cylinders from the CWF products and then cutting the cores into $3-\mathrm{cm}-$ long samples using a low-speed saw with a diamond wafering blade. The coring and cutting steps were performed using absolute ethanol as the cutting fluid to minimize the loss of exposed halite inclusions. Enough samples were prepared for treatment of two specimens under each time-temperature condition to provide sufficient material to conduct XRD analysis and 1 PCT. Several samples were retained for use in replicate XRD analysis and PCTs as a "no heat" CWF source material for comparison with the heat-treated samples and to provide a measure of the uncertainty in the analyses and testing.

\subsubsection{Short-Term Heat Treatment}

The heat treatments at $600,700,800$, and $850{ }^{\circ} \mathrm{C}$ were conducted in a small electrical furnace with a NIST-traceable thermocouple placed near the center. The furnace was adjusted to the desired temperature and allowed to stabilize. Two samples that were to be heat-treated at that temperature for the same duration were placed in a platinum crucible, which was then placed into the furnace. The crucibles were used to facilitate handling and to keep them from contacting the firebrick furnace lining in the event a CWF material became sticky or melted. Samples were placed in the furnace at different times so that all of the samples to be heated at the same temperature could be cooled simultaneously. The furnace temperature was monitored using the NIST-traceable thermocouple and found to remain stable within $1{ }^{\circ} \mathrm{C}$ for all test durations (based on frequent observations of the thermocouple temperature read-out). At the end of the heat treatment, the power to the furnace was turned off with the samples left in the furnace. This method provides slow cooling similar to what will occur with large CWF products. The temperature of the thermocouple was recorded periodically for the first two hours after the furnace had been turned off following treatments at 800 and $850{ }^{\circ} \mathrm{C}$. The cooling curves are shown in Fig. 6. Although they were not measured directly, the temperatures of the CWF samples are assumed to be about the same as the measured oven temperatures, based on their small size. Attempts to monitor the sample temperatures directly were not successful. The treated samples were removed from the furnace after it had cooled to near room temperature. They were placed in labeled plastic bags and stored in a desiccator. 


\subsection{ANALYSIS OF HEAT-TREATED CWF SAMPLES}

\subsubsection{Preparation of Heat-Treated CWF Test Samples}

The materials that had been heated at 400 or $500{ }^{\circ} \mathrm{C}$ were first broken using a hammer, then the large pieces were crushed further using a steel mortar and pestle. The resulting fragments were crushed until they passed through a 100 mesh $(150 \mu \mathrm{m})$ sieve. The material was then placed in a laboratory grinding mill and further size-reduced so that the largest glass fragments were less than about $20 \mu \mathrm{m}$. Care was taken to ensure that all of the crushed material was carried through the size-reduction process and that the final fraction contained all of the material from the starting monolith. Representative SEM images of the $-100+200$ and $-200+325$ mesh size fractions and the pulverized CWF material are shown in Fig. 7. The large particles seen in Figs. $7 \mathrm{c}$ and $7 \mathrm{~d}$ are binder glass, and the much smaller particles are sodalite (and halite). The size difference occurs because sodalite is much more friable than the glass. The XRD spectra of the finely pulverized materials were not significantly different from the spectra of the $-100+200$ or $-200+325$ mesh size fractions, so XRD spectra for the other materials were obtained using the $200+325$ mesh size fractions.

The short-term heat-treated CWF samples were crushed and sieved to isolate both the $-100+200$ and $-200+325$ mesh size fractions. This was done by placing the cylindrical samples directly in the laboratory mill and pulsing the mill several times to fracture and crush the material. The crushed material was passed through 100, 200, and 325 mesh sieves using a laboratory sifter. Material that did not pass through the 100 mesh sieves was poured back into the mill for further size reduction, except one piece was retained as an archive sample. Small amounts of each heat-treated CWF sample were processed until more than $1 \mathrm{~g}$ of the $-100+200$ mesh size fraction was collected for use in PCTs. About $5.7 \mathrm{~g}$ of the $-100+200$ mesh size fraction was generated with the "no heat" CWF material (i.e., material that had not been heattreated). The material generated in the $-200+325$ mesh size fraction was retained for XRD analysis.

\subsubsection{XRD of Heat-Treated CWF Samples}

Powder X-ray diffraction analysis was performed using the $-200+325$ mesh size fraction of most samples. Finely pulverized samples of the 1-year long-term heat-treated samples were analyzed. Spectra were collected using $\mathrm{Cu} \mathrm{K}_{\alpha}$ radiation at $40 \mathrm{kV}$ and $100 \mathrm{~mA}$ using a nominal scan rate of 2.4 degrees/minute. As was done for the salt-loaded CWF materials, the spectral peaks in spectra with the heat-treated CWF materials were matched with those in reference spectra of sodalite, halite, and nepheline based on the measured $d$-spacings and relative peak heights. (The $d$-spacings and relative peak heights of the reference spectra are summarized in Table 8.)

The spectra for the CWF samples heat-treated at 400 and $500{ }^{\circ} \mathrm{C}$ are shown in Figs. 8 and 9, respectively. The $d$-spacings and relative peak heights and areas (relative to the sodalite $3.624 \AA$ peak) are summarized in Tables 19 and 20. The $d$-spacings and relative peak heights were used to match the spectra to reference spectra for sodalite, halite, and nepheline, and the relative peak areas were used to compare the relative amounts of these phases in the different materials. The most intense sodalite peaks were used as internal standards to help match the less intense peaks 
to corresponding nepheline or halite peaks based on both the $d$-spacings and the relative peak heights. The $d$-spacings in most spectra were shifted by up to several hundredths of an Angstrom from those of the reference spectra, but the shifts were not linear. That is, the $d$ spacings for major sodalite peaks differed from the reference material values of $6.28,3.624$, and $2.563 \AA$ by different amounts. The shifts of the sodalite peaks are given in the tables, where

$$
\text { peak shift }=(\text { reference sodalite } d-\text { spacing })-(\text { measured } d-\text { spacing })
$$

The shifts of the sodalite peaks are included in the tables. The relative areas of several major peaks assigned to halite, nepheline, and sodalite are summarized in Table 21 for the CWF samples that were heat-treated at 400 and $500{ }^{\circ} \mathrm{C}$. Note that the halite peak at $2.821 \AA$ was not resolved from the sodalite peak at $2.807 \AA$ in the spectra of the samples treated for 1 week at either temperature, but is clearly present (see Figs. 8a and 9a). The relative areas of the major halite and sodalite peaks in the heat-treated CWF samples are plotted in Figs. 10a-10d. There are no trends in the amounts of halite or sodalite with the heating duration at either temperature.

An XRD spectrum collected for the CWF source material PC10402 used in the heat treatments is shown in Fig. 11. Five analyses of the source material were performed to gauge the repeatability and reproducibility of the XRD analyses and evaluate the significance of differences seen in spectra for the different heat-treated materials. Analyses 1,2, and 3 were performed by the same analyst, who was not made aware they were replicate samples. Analyses 4 and 5 were performed by two different analysts at different times. The $d$-spacings and the relative peak heights and areas in the 5 analyses are tabulated and compared with the reference materials in Table 22 . The relative peak heights and areas of the major peaks are summarized in Table 23 for ease of comparison. The values of the mean and 2 standard deviations for replicate analyses are included.

The spectra for the short-term heat-treated CWF samples are shown in Figs. 12-15 for treatments at $600,700,800$, and $850{ }^{\circ} \mathrm{C}$, respectively. The $d$-spacings and the relative peak heights and areas for the short-term heat-treated CWF samples are summarized in Tables 24-27. The $d$ spacings and relative peak heights were used to match the spectra with the reference spectra, and the relative peak areas were used to compare the relative amounts of halite, nepheline, and sodalite in the various heat-treated CWF samples and the no-heat CWF source material. The most intense sodalite peaks were used as internal standards to help match the less intense peaks to corresponding nepheline or halite peaks based on both the $d$-spacings and the relative peak height. The shifts of the sodalite peaks relative to the reference spectrum were used to help identify minor halite and nepheline peaks. The relative peak heights of the major peaks assigned to halite, nepheline, and sodalite for the various heat-treated CWF samples are summarized in Table 28, and the relative peak areas are summarized in Table 29. The areas of the major halite, sodalite, and nepheline peaks are plotted in Fig. 16; the horizontal lines show the mean values for halite and sodalite in replicate analyses of the no-heat CWF source material (see Table 23). In Table 29, relative peak areas that exceed the mean of replicate analyses of the CWF source material by more than 2 standard deviations are shown in bold font. These are interpreted to exceed the experimental uncertainty. The amounts of halite and sodalite measured in the different heat-treated CWF samples appear to show random variations that exceed the experimental uncertainty in several cases, but do not show a trend with either the temperature or duration of the heat treatment. Nepheline was not detected in the CWF source material used in 
the heat-treatment study, but several peaks in the spectra of some of the heat-treated CWF samples were matched to nepheline peaks. However, the absence of major nepheline peaks suggests these matches may be fortuitous in cases where only one peak was matched. The number of peaks assigned to nepheline increased with the treatment temperature and duration, and the presence of nepheline in those samples is more certain.

\subsubsection{PCT with Heat-Treated CWF Samples}

The crushed long-term heat-treated CWF samples were washed with several aliquots of absolute ethanol to remove fines and then dried in a $90{ }^{\circ} \mathrm{C}$ oven. The masses of the dried materials were measured and used to determine the amounts of demineralized water to be used in the RWS tests. The test data for RWS conducted with the heat-treated CWF samples are given in Table 30. Note that a single RWS was conducted with the no-heat material, but the solution was divided into 3 aliquots that were passed though 3 separate $0.45-\mu \mathrm{m}$ pore size filters and collected in 3 solution bottles for separate analyses. This was done to provide a gauge of the analytical uncertainty. The washed materials were dried overnight in a $70{ }^{\circ} \mathrm{C}$ oven prior to starting the PCTs. The dried materials were transferred to the test vessels and weighed, then an amount of demineralized water equal to about 10 times the mass of CWF was added, and the vessel was sealed. The vessels were placed in a $90{ }^{\circ} \mathrm{C}$ oven and left undisturbed for 7 days and 2 hours. The vessels were then removed from the oven and allowed to cool to near room temperature before opening. The test solutions were passed through $0.45-\mu \mathrm{m}$ pore-size filters and then analyzed for $\mathrm{pH}$. The solutions were then diluted with demineralized water and acidified with about 4 drops of concentrated nitric acid. The solutions were analyzed for Al, B, Na, and Si with ICP-MS. The test data for the 7-day PCTs are given in Table 31.

The solution results and calculated normalized mass losses are summarized in Table 32 for the RWS tests and in Table 33 for the PCTs. The normalized mass losses based on the RWS and PCT results are plotted in Figs. 17a-17d for tests with the long-term heat treated samples and in Figs. 18a-18d for tests with the short-term heat-treated samples. The three horizontal lines drawn in Figs. 18a-18d show the results of tests conducted with CWF source material PC10402 that was not heat treated. These are used as reference lines for test repeatability (comparison of the three lines with each other) and the effects of the various heat treatments (comparison of the lines with the bar heights) on the halite content and chemical durability. The uncertainty in the RWS results based on the 3 analyses of the no-heat test solutions is only $0.8 \%$ (relative standard deviation). Except for the material heated 28 days at $600{ }^{\circ} \mathrm{C}$, the $\mathrm{Cl}^{-}$concentrations measured in the RWS tests with the heat-treated materials are lower than in tests with material that was not heated. The values of $N L(\mathrm{~B}), N L(\mathrm{Na})$, and $N L(\mathrm{Si})$ for tests with the heat-treated CWF samples are either the same as when the material was not heated or lower, within the testing uncertainty. 


\section{DISCUSSION}

\subsection{EFFECTS OF SALT AND BINDER GLASS CONTENTS}

During the processing of actual CWF waste forms, the amount of waste salt occluded in zeolite 4A and the amount of binder glass mixed with the SLZ will be controlled by mass. The effects of the relative amounts of salt, zeolite, and binder glass used to make waste forms on the phase composition and durability will be due to the different amounts of halite and nepheline that are formed.

\subsubsection{Effects on Phase Composition}

As seen in salt-loaded CWF products S1A, S1B, and S2C, loading significantly less than the stoichiometric amount of salt into the zeolite results in the formation of nepheline during processing. The relative amounts of sodalite, halite, and nepheline in different CWF products were compared in Sections 2.3 and 3.2 based on the XRD results, but the contents were not quantified. The actual amounts of sodalite can be estimated based on the amount of SLZ used to make each product, and the amount of halite was quantifiedly measured by standard addition (see Section 4.2). A source of nepheline was not found to quantify the XRD results. Instead, the amount of nepheline formed in the various salt-loaded CWF products is estimated by assuming the available $\mathrm{NaCl}$ is stoichiometrically converted to sodalite and the excess zeolite is stoichiometrically converted to nepheline. The number of moles of nepheline formed in materials made using SLZ with different salt contents can be predicted by first using the stoichiometry given in Eq. 1 and the number of $\mathrm{Cl}^{-}$per formula (based on the as-batched compositions, see Table 5) to calculate the amount of sodalite that is formed, and then using the amounts of "excess" zeolite to calculate the amount of nepheline formed, or the amounts of excess $\mathrm{NaCl}$ to calculate the amount of halite formed. For example, the amounts of sodalite and nepheline produced for the nominal loading of $3.6 \mathrm{Cl}^{-}$per unit cell zeolite in the SLZ can be estimated based on the stoichiometry given in the reaction in Eq. 10:

$$
\underset{\text { SLZ }}{\mathrm{Na}_{12}\left(\mathrm{AlSiO}_{4}\right)_{12} \bullet 3.6 \mathrm{NaCl}} \rightarrow \underset{\text { sodalite }}{\operatorname{SL}} \rightarrow \underset{\text { nepheline }}{\mathrm{Na}_{8}\left(\mathrm{AlSiO}_{4}\right)_{6} \mathrm{Cl}_{2}}+\underset{\text { Nali }}{0.3 \mathrm{Na}_{4}\left(\mathrm{AlSiO}_{4}\right)_{4}}
$$

In this simple model, we presume that sodalite, nepheline, and halite are formed only by the transformation of SLZ, and that the reactions occur to completion by consuming all of the available $\mathrm{NaCl}$ and zeolite to form sodalite. The excess $\mathrm{NaCl}$ or zeolite is then converted to halite or nepheline. This model provides upper limit amounts of nepheline and halite that can form from SLZs having different salt loadings that can be compared with the XRD results. In general, the amount of sodalite that can form per unit formula of SLZ, based on the salt loading is:

moles sodalite per formula $S L Z=\mathrm{Cl}^{-}$per formula $S L Z \times \frac{2 \text { moles sodalite per formula } S L Z}{4 \mathrm{Cl}^{-} \text {per unit formula } S L Z}$ 
(The stoichiometry of each component shown in Eq. 10 is referred to as a formula for mass balance purposes.) As shown in the reaction in Eq. 10, the availability of $3.6 \mathrm{Cl}^{-}$per formula SLZ will result in the formation of $3.6 \times(2 / 4)=1.8$ moles of sodalite. The amount of zeolite in excess of what is transformed to sodalite is:

$$
\text { moles excess zeolite per formula } S L Z=\left(4-\mathrm{Cl}^{-} \text {per formula } S L Z\right) \times \frac{1 \text { mole zeolite }}{4 \text { moles }^{-} l^{-}}
$$

where the value of 4 in the parenthetic term accounts for the stoichiometric transformation of 4 moles $\mathrm{NaCl}$ to 1 mole sodalite. For the reaction in Eq. 10 , there is $(4-3.6) \times(1 / 4)=0.1$ moles of excess zeolite in the SLZ. The amount of nepheline that can be formed from the excess zeolite is calculated as:

$$
\text { moles nepheline }=\text { moles excess zeolite per formula } S L Z \times \frac{3 \text { moles nepheline }}{1 \text { mole zeolite }}
$$

As shown in the reaction in Eq. 10, 3.6 $\mathrm{Cl}^{-}$per formula SLZ will result in the formation of $0.1 \times$ $(3 / 1)=0.3$ moles of nepheline. For the materials made with excess halite, the amount of excess halite is calculated as:

$$
\text { moles excess halite }=\mathrm{Cl}^{-} \text {per formula } S L Z-4
$$

where the value of 4 is for stoichiometric transformation of SLZ to sodalite. The number of moles, masses, and mass fractions of sodalite, nepheline, and halite calculated for the materials with various numbers of $\mathrm{Cl}^{-}$per formula using the formulae in Eqs. 11a-11d are summarized in Table 34; negative values are reported as 0 (i.e., the phase is predicted to be absent).

Products S1A (and S1B) and S2A are predicted to generate large amounts of nepheline, and products $\mathrm{S} 3 \mathrm{~A}$ (and $\mathrm{S} 3 \mathrm{~B}$ ), S3C, and $\mathrm{S} 3 \mathrm{E}$ are predicted to generate small amounts of nepheline, but none of these products are predicted to generate any halite. Products S4A and S5B are predicted to generate small amounts of halite but no nepheline. Products G1A, G2A, G4A, and G5A are predicted to have the same crystalline phase composition as products S3A, S3C, and $\mathrm{S} 3 \mathrm{E}$, since all were made with the same salt loading in the SLZ. However, the total amounts of each phase in the CWF will decrease as the glass content increases. The relative amounts of SLZ and glass used to make the CWF are not expected to affect the relative amounts of each phase that forms. Transformation of SLZ to sodalite is expected to occur before the glass becomes fluid, so the glass is not expected to participate in the transformation. The sodalite, halite, and nepheline (if it forms) become encapsulated in the binder glass after they have formed. However, small amounts of sodalite may dissolve into the glass, which will increase the amounts of $\mathrm{Na}, \mathrm{Al}$, and $\mathrm{Si}$ in the glass. This will also slightly increase the amount of halite inclusions that form due to the low solubility of chloride in borosilicate glass.

The predicted crystalline phase compositions can be compared qualitatively with the XRD results expressed as height $\%$ in Table 13 or area\% in Table 14 (see also Fig. 2). The height and area values for halite and nepheline peaks in different spectra that have been normalized to that 
of the strongest sodalite peak are expected to be proportional to the amounts of each phase. These comparisons reflect the relative amounts of halite, nepheline, and sodalite that form in CWF materials made with different salt and glass loadings, but are only semiquantitative. (Uncertainty in the quantitation of the major halite peaks is discussed in Section 4.5.3.) The total crystalline content of each CWF material is expected to be nearly equal to the percent of SLZ used to make it. That is, only a small amount of zeolite, halite, or sodalite is expected to dissolve into the binder glass under the processing conditions that were used to make these CWF materials. The total crystalline content was not measured directly.

The areas of several peaks were used to estimate the relative amounts of each phase that are present in each CWF product. The consistencies of the two peaks used to identify halite, the three peaks used to identify nepheline, and the three peaks used to identify sodalite in the XRD spectra are evaluated in Fig. 19. The relative peak heights of the halite and sodalite peaks are better correlated (with each other) than the relative peak areas. Note that the both the height and area of the sodalite $6.280 \AA$ peak decrease as the heights and areas of the 2.563 and $2.093 \AA$ peaks increase. This may be an indication that another (unidentified) phase is contributing to the 6.280 Å peak.

Halite is detected in all CWF products except S1A, S1B, and S2B (based on the major peaks at 2.821 and $1.994 \AA$ ), whereas it is only predicted to be present in materials S4A and S5B. The greatest amount of halite is detected in material S5B, which is consistent with the prediction in Table 34. Nepheline is detected in all materials (based on the major peaks at 3.2731 and 3.0059 $\AA$ ), whereas it is predicted to be absent in products S4A or S5B. The greatest amounts of nepheline are detected in products $\mathrm{S} 1 \mathrm{~A}, \mathrm{~S} 1 \mathrm{~B}$, and $\mathrm{S} 2 \mathrm{~B}$, which is consistent with the predictions in Table 34. The relative amounts of halite and nepheline in products G1A, G2A, G4A, and G5A are similar to the relative amounts in products $\mathrm{S} 3 \mathrm{~A}, \mathrm{~S} 3 \mathrm{~B}, \mathrm{~S} 3 \mathrm{C}$, and $\mathrm{S} 3 \mathrm{E}$. The presence of halite and nepheline in CWF materials for which they are predicted to be absent indicates the reactions transforming SLZ to sodalite are not $100 \%$ efficient. This is consistent with the observation of powdery white inclusion phases of unreacted zeolite in most of the CWF products (see Appendix).

The most chloride measured by the RWS tests (i.e., by the water-wash of the PCT sample materials) was in tests with products G1A, S5B, and G2A, which had the highest $\mathrm{Cl}$ contents of the CWF materials that were tested. The amounts of chloride measured by the RWS test, expressed as the measured $\mathrm{Cl}$ concentration, and the halite contents measured by $\mathrm{XRD}$, as relative peak height or area, are plotted against the total $\mathrm{Cl}$ content of the salt-loaded $\mathrm{CWF}$ products in Fig. 20a (product S1A is excluded). The RWS results are correlated with the total $\mathrm{Cl}$ content of the CWF product, as shown by the line in the plot. The equation of the line is

$$
R W S[C l]=2260+924 f(C l) ; \mathrm{R}^{2}=0.89
$$

The lack of correlation between the XRD peak heights and $\mathrm{Cl}$ content in Fig. 20a occurs because the halite content is not proportional to total $\mathrm{Cl}$ content, since most of the $\mathrm{Cl}$ is contained in sodalite. Figure $20 \mathrm{~b}$ shows the correlation between the RWS results and the mass \% salt in the SLZ for CWF products made with 25 mass \% binder glass. The equation of the regression line is 


$$
R W S[C l]=1080+133 \text { mass } \% \text { salt; } \mathrm{R}^{2}=0.92
$$

The correlations with the RWS results cannot be applied to $\mathrm{Cl}$ contents less than about 3.7 mass\%, since negligible amounts of halite form. Since $\mathrm{Cl}$ is only supplied to the CWF by the salt, these results indicate that the RWS test can be used to verify that the appropriate amount of salt was added to the SLZ and the CWF.

\subsubsection{Effects on Chemical Durability}

The relationship between the phase composition (based on XRD analyses) and the 7-day PCT responses is shown in Fig. 21. The correlations of the phase compositions with $N L(\mathrm{~B})$ and $N L(\mathrm{Si})$ are dominated by the results of product $\mathrm{S} 1 \mathrm{~A}$, which has the greatest amount of nepheline and the highest PCT response. The nepheline contents of the other materials are similar, as shown on the expanded scale in Fig. 21b. Although the releases of B and Si are insensitive to small amounts of nepheline ( 3 and 4 area $\%$ for the two peaks), they increase significantly when more nepheline is present, as in CWF materials S1A and S2B. The release of $\mathrm{Na}$ is not correlated with the amounts of nepheline or halite. The apparent correlations of $N L(\mathrm{~B})$ and $N L(\mathrm{Si})$ with the halite content is probably a result of the correlation with the salt loading rather than a dependence on the halite content.

The averages of triplicate test results $N L(\mathrm{~B}), N L(\mathrm{Si})$, and $N L(\mathrm{Na})$ are listed in Table 18 and compared in Fig. 22 (uncertainty bars are drawn at $\pm 10 \%$ of the plotted values to represent the analytical uncertainty). Differences in $N L(\mathrm{~B}), N L(\mathrm{Si})$, and $N L(\mathrm{Na})$ occur because $\mathrm{B}, \mathrm{Na}$, and $\mathrm{Si}$ are released from different phases as the CWF dissolves, and the stoichiometries of each phase differ from the overall stoichiometry of the CWF. The amounts of B, Na, and Si estimated to be in the binder glass and sodalite phases of the different salt-loaded CWF materials based on the as-batched compositions are summarized in Table 35; the fraction of Na present in halite is neglected as insignificant for the purpose of this analysis. The overall mass fractions in the CWF materials used to calculate the normalized mass losses are included in Table 35 for comparison. The values of $N L(\mathrm{~B}), N L(\mathrm{Na})$, and $N L(\mathrm{~B})$ provide insight into the relative extents of dissolution of sodalite and the binder glass. For the extreme case where only sodalite dissolves, $N L(\mathrm{~B})$ would be zero and $N L(\mathrm{Na})$ would be about 1.5 times $N L(\mathrm{Si})$, since the sodalite contains about $92 \%$ of the $\mathrm{Na}$ and $65 \%$ of the $\mathrm{Si}$. At the other extreme where only the binder glass dissolves, $N L(\mathrm{~B})$ would be about $3 \times N L(\mathrm{Si})$, since the binder glass contains $100 \%$ of the $\mathrm{B}$ and about $35 \%$ of the $\mathrm{Si}$; and $N L(\mathrm{Si})$ would be about $5 \times N L(\mathrm{Na})$, since the binder glass contains about $35 \%$ of the Si and only about $8 \%$ of the Na. (These comparisons presume the releases from each phase are stoichiometric.) Figure 22 shows that the values of $N L(\mathrm{~B})$ and $N L(\mathrm{Na})$ are about 0.08 and $0.14 \mathrm{~g} / \mathrm{m}^{2}$, respectively, for all materials except $\mathrm{S} 1 \mathrm{~A}$, and the values of $N L(\mathrm{Si})$ are between about 0.05 and $0.09 \mathrm{~g} / \mathrm{m}^{2}$ for different materials.

Values of $N L(\mathrm{Na})$ range from being nearly equal to $N L(\mathrm{Si})$ to being about $3 \times N L(\mathrm{Si})$. This indicates that the same amount of binder glass dissolves in tests with all materials (except S1A), but different amounts of sodalite dissolve. Note that the mass fraction of $\mathrm{B}$ in the different CWF materials ranges from $f(\mathrm{~B})=0.118$ to $f(\mathrm{~B})=0.175$, which is $32 \%$, where the mass fraction of $\mathrm{Si}$ ranges from $f(\mathrm{Si})=0.196$ to $f(\mathrm{Si})=0.227$, which is $14 \%$. 
Because the halite exposed at the surface is presumed to have been completely removed during the RWS test, it is assumed that an insignificant amount of halite dissolves during the PCT. Therefore, the $\mathrm{Na}$ that is released in the PCTs is due to dissolution of binder glass and sodalite. Most of the $\mathrm{Na}$ in the CWF materials is contained in the sodalite phase. Figure 20 indicates that the $N L(\mathrm{Na})$ values for tests with all materials are about $0.05 \mathrm{~g} / \mathrm{m}^{2}$ higher than the $N L(\mathrm{~B})$ values. Test $\mathrm{S} 1 \mathrm{~A}$ is an exception, for which the average value of $N L(\mathrm{~B})$ is about $1.7 \mathrm{~g} / \mathrm{m}^{2}$ higher than the average value of $N L(\mathrm{Na})$. The "excess" $\mathrm{Na}$ is due to the transient dissolution of sodalite that occurs initially.

This casts suspicion on the high B release measured for material S1A, even though the results of triplicate tests were similar. The releases of $\mathrm{B}$ and $\mathrm{Na}$ are expected to be equally sensitive to the durability of the binder glass because they have similar concentrations in the binder glass. However, the likelihood that the solutions are saturated with respect to sodalite would set solubility limits for $\mathrm{Na}$ and $\mathrm{Si}$, but not for $\mathrm{B}$.

\subsection{QUANTITATION OF HALITE CONTENT}

The halite contents measured in the XRD spectra were quantified using the method of standard addition. An extra sample of CWF material PC10402 that had been prepared as part of the shortterm heat-treatment series and stored in a desiccator was crushed with a laboratory mill and sieved to isolate about $2.55 \mathrm{~g}$ of the $-200+325$ mesh size fraction. The sized material was not washed to remove fines. Analytical-grade $\mathrm{NaCl}$ was crushed and sieved to $-200 \mathrm{mesh}$, and then stored in a desiccator. Samples of the crushed CWF were weighed into vials, and a small amount of salt was added. The vials were placed in a $90{ }^{\circ} \mathrm{C}$ oven overnight to ensure the salt was dry, then the vials were weighed and the mass of salt calculated by assuming all mass loss due to heating was water driven from the salt. The mixture was then passed through a 200 mesh sieve to improve mixing. A few crystals of salt did not pass through the sieve. These were weighed and discarded. The total mass of the mixture was reweighed after sieving. Mass loss beyond the mass of the discarded salt crystals was attributed to loss of CWF stuck in the sieve. The adjusted masses of salt and CWF were used to calculate the mass\% salt in the mixture. The data are summarized in Table 36. The spectral peaks for CWF material PC10402 and the three mixtures of $\mathrm{PC} 10402+\mathrm{NaCl}$ are listed in Table 37. The peak area values for the major halite peaks at 2.821, 1.994, and $1.628 \AA$ are plotted against the amount of added $\mathrm{NaCl}$ in Fig. 23. The averages of the area\% values determined from replicate analyses of PC10402 (see Table 23) are plotted at $0 \%$ added $\mathrm{NaCl}$. The regression fits from the plot:

$$
\begin{array}{ll}
\text { for 2.821 } \AA: & \mathrm{Y}=5.43+2.97 \mathrm{X} \\
\text { for 1.994 } \AA: & \mathrm{Y}=2.86+1.54 \mathrm{X} \\
\text { for } 1.628 \AA: & \mathrm{Y}=6.43+5.36 \mathrm{X}
\end{array}
$$

where $\mathrm{Y}$ is the area $\%$ value and $\mathrm{X}$ is the mass $\%$ added $\mathrm{NaCl}$. Assuming that the peak area decreases linearly with the halite content, the $x$-intercept gives the negative of the mass $\%$ halite $(\mathrm{NaCl})$ in material PC10402. Rearranging these equations to solve for the mass $\% \mathrm{NaCl}(\mathrm{X})$ as a function of the measured area $\%(Y)$ gives:

for $2.821 \AA \AA \quad \quad X=-1.83+0.337 \mathrm{Y}$ 


$$
\begin{array}{ll}
\text { for } 1.994 \AA: & \mathrm{X}=-1.86+0.649 \mathrm{Y} \\
\text { for } 1.628 \AA: & \mathrm{X}=-1.20+0.187 \mathrm{Y}
\end{array}
$$

The negatives of the values of $\mathrm{X}$ when $\mathrm{Y}=0$ give halite content of material PC10402 based on the three fits: $1.83,1.86$, and 1.20 mass $\%$. (The value $X=0$ represents no added $\mathrm{NaCl}$ ). The average halite content of the crystalline phases is 1.6 mass \%. It must be remembered that this is the percentage of the crystalline phases in the CWF that is halite, not the percentage of CWF that is halite. Assuming that the glass content of CWF remains $25 \%$ (for CWF material $\mathrm{PC} 10402)$, the halite content of the CWF is about $0.75 \times 1.6 \mathrm{mass} \%=1.2 \mathrm{mass} \%$.

The halite contents of other salt-loaded CWF compositions and heat-treated CWF materials can be calculated from the measured area\% values by shifting the equations such that the $x$-intercepts correspond to 0 mass $\%$. No peak is detected at $1.628 \AA$ for many samples, and the equations for the peaks at 2.821 and $1.994 \AA$ are:

$$
\begin{array}{ll}
\text { for } 2.821 \AA: & \mathrm{X}=0.337 \mathrm{Y} \\
\text { for } 1.994 \AA: & \mathrm{X}=0.649 \mathrm{Y}
\end{array}
$$

The halite concentrations in the various CWF materials are summarized in Table 38, where the crystalline content of a material is assumed to be the same as the mass \% SLZ used to make it. Upper limits given when a peak was not detected were calculated assuming a detection limit of 0.1 area $\%$.

\subsection{EFFECTS OF HEAT TREATMENT AND TTT DIAGRAM}

Early versions of the WASRD included a requirement that vitrified waste forms be maintained at temperatures below $400{ }^{\circ} \mathrm{C}$, which is about $100{ }^{\circ} \mathrm{C}$ below the typical glass transition temperature of about $500{ }^{\circ} \mathrm{C}$. (The glass transition temperature is the temperature at which the glass passes from a plastic state to a rigid state.) Maintaining a glass below its transition temperature is intended to ensure the stability and consistency of vitrified waste forms by preventing changes in the phase composition. This is because solid-state diffusion becomes negligibly slow in rigid glass. In the case of standard borosilicate glasses, small amounts of crystalline phases such as nepheline, acmite, and spinel can form when some glass compositions are held at temperatures above the glass transition temperature. Whereas the formations of acmite and spinel have negligible effect on glass durability, the formation of nepheline can lower the durability of some glasses, due primarily to the removal of aluminum and silicon from the glass phase. The specification that the waste forms be maintained at temperatures below $400{ }^{\circ} \mathrm{C}$ has been removed in the most recent revision of the WASRD (REV04), but TTT diagrams must still be provided.

The TTT diagram summarizes the stability of the phase compositions with time and temperature. Depending on whether the different phases are simply identified or quantified, TTT diagrams can be qualitative or quantitative. The WASRD does not provide specifications for the TTT diagram other than that its purpose is for the "identification of temperature limits necessary to preserve the properties of the vitrified HLW." Because the primary property of interest is the chemical durability, the durabilities of heat-treated CWF materials as measured in 7-day PCTs are used to evaluate the impact of any changes in the phase assemblage on the chemical durability. The 
sensitivity of the PCT response to the phase composition was measured separately in the tests with the salt-loaded CWF materials.

The results of PCTs and phase composition analyses for the various heat-treated CWF materials are plotted on a TTT plot in Fig. 24. The points on the diagram indicate the temperature-time conditions that were analyzed and the numbers give the values of $N L(\mathrm{~B})$ for 7-day PCT in units of $\mathrm{mg} / \mathrm{m}^{2}$. The squares drawn around some points denote samples in which at lease one major nepheline peak was detected; halite was detected in all samples. The points are plotted at time values that include the 16 hours at $915{ }^{\circ} \mathrm{C}$ when the CWF materials were made. The four points plotted at 20 hours without adjacent values are for samples that were heat-treated for 4 hours at $600,700,800$, or $850^{\circ} \mathrm{C}$ but not subjected to PCT. Results for the no heat CWF source material used in the short-term heat-treatment tests are plotted at 16 hours at $915^{\circ} \mathrm{C}$. The CWF used as the source material in the short-term heat treatment study had higher halite concentration than those detected in any of the heat-treated samples, but nepheline was not detected in the source CWF material. This indicates that nepheline concentrations increased to detectable levels during heat treatment. However, the chemical durability of the CWF was not affected by the formation of nepheline.

A parabolic curve is drawn in Fig. 24 to qualitatively illustrate the TTT curve for the in-growth of nepheline to detectable levels. The curve is a simple empirical fit to the test results and is not intended to imply any knowledge of nucleation or growth kinetics. It was drawn to the left of samples in which only a few (possibly fortuitous) nepheline peaks were matched. Nepheline was not detected in several samples that lie to the right of the curve. These may contain concentrations of nepheline below the XRD detection limit.

The nose of the TTT curve (the minimum time required to form nepheline) is drawn at 0.7 days at $850^{\circ} \mathrm{C}$. This is because 2 peaks were matched to nepheline for the sample heated at $850{ }^{\circ} \mathrm{C}$ for 4 hours (plus the 16 hours it was processed at $915{ }^{\circ} \mathrm{C}$ ). No major nepheline peak was detected in the samples heated at 600,700 , or $800^{\circ} \mathrm{C}$ for 4 hours. Likewise, nepheline was not detected in the CWF source material used to generate the TTT diagram (which was made by heating at $915{ }^{\circ} \mathrm{C}$ for about 16 hours). The average of triplicate PCTs with the source material is included in Fig. 24. Neither the detection limit for nepheline nor the sensitivity of the XRD peak heights (or areas) to the nepheline content was determined. The curve represents the minimum time needed for a detectable amount of nepheline to grow in the CWF at a particular temperature. Depending on the time actual waste forms are processed at $915{ }^{\circ} \mathrm{C}$ and their cooling rates after processing, the potential exists that small amounts of nepheline may nucleate and grow. However, this will not be detrimental to the chemical durability of the waste form.

\subsection{COMPARISON OF CWF DURABILITY TO EA GLASS}

Although the PCT response of material S1A as $N L(\mathrm{~B})$ is higher than the response of other materials, it is still about 10 times lower than the $N L(\mathrm{~B})$ response in PCT with the Environmental Assessment (EA) glass that is used as a benchmark for the chemical durability requirement for HLW glasses in the WASRD (DOE 2002, Section 4.8.2.B). The WASRD requirement states, "For acceptance, the mean concentrations of lithium, sodium, and boron in the leachate, after normalization for the concentrations in the glass, shall be less than those of the benchmark glass" 
(DOE 2002, Section 4.8.2.B.2). Table 39 provides the results of 7-day PCTs conducted with the EA glass at several laboratories and summarizes the results of 7-day PCTs with the salt-loaded and heat-treated CWF materials in terms of the normalized concentrations.

It should be noted that the PCT calls for an amount of demineralized water that is ten times the mass of the crushed material. Because the densities of the PCT materials are significantly lower than that of the EA glass, (nominally $2.3 \mathrm{~g} / \mathrm{cm}^{3}$ for CWF materials compared with about $2.7 \mathrm{~g} / \mathrm{m}^{3}$ for the EA glass), the specific surface area of the crushed EA glass (about $0.020 \mathrm{~m}^{2} / \mathrm{g}$ ) is lower than that of the CWF materials (about $0.023 \mathrm{~m}^{2} / \mathrm{g}$ ). This means that the exposed surface area of CWF materials is about $15 \%$ higher than that of EA glass under the test conditions. If the dissolution rates were the same, the normalized concentrations in tests with CWF would be $15 \%$ higher than those in tests with the EA glass. The differences in material density are not taken into account in Table 39, so direct comparison of the tabulated values for CWF materials and the EA glass is conservative.

\subsection{UNCERTAINTIES}

\subsubsection{Presence of Powdery Inclusions in Salt-Loaded CWF Products}

As discussed in the Appendix, numerous inclusions of sodalite and halite crystallites that were not encapsulated by the binder glass during processing were present in all salt-loaded CWF products. These resulted from hard lumps of SLZ that formed during the salt-occlusion step. Products made later with SLZ that had been sieved to remove the lumps did not have inclusions. The decision was made to use these materials in the testing program because they provided less than ideal CWF materials that will likely result from large-scale production. The SLZ used to make actual waste forms will not be sieved to remove lumps prior to mixing with the binder glass.

The crystalline composition of the inclusions recovered from salt-loaded CWF product G2A was nearly identical to that of the CWF product itself. Although samples were prepared so as to retain inclusions in the mixtures of crushed products that were used in testing, it is not known how well the crystallites in the inclusions were retained during sample preparation or how well their contents in the salt-loaded CWF products were represented by the test samples. The abundance of the powdery inclusions in the salt-loaded CWF products was estimated for CWF product $3 \mathrm{~A}$, which appeared to have the greatest abundance of all products. The area fraction of the white inclusions on the surface (see Appendix A, Fig. A.4) was measured to be about 3.0 area $\%$. The maximum volume $\%$ is taken to be $3 \%$ for all salt-loaded CWF materials. The crushed and sized samples used for composition analyses, XRD analyses, and PCTs contained up to $3 \%$ sodalite and halite that was not encapsulated by glass. This probably resulted in small biases in the compositions, sodalite and halite contents, and RWS responses of a similar magnitude. This is negligible relative to other experimental uncertainties. Similar powdery inclusions were not detected in the CWF source material used in the heat-treatment studies. 


\subsubsection{Presence of Nepheline in CWF Products with the Nominal Composition}

Trace amounts of nepheline were detected in the XRD spectra of the four CWF products made with the nominal composition of 10.7 mass\% salt in the SLZ and 25 mass $\%$ binder glass (products S3A, S3B, S3C, and S3E), but not in the CWF source material PC10402 used for heattreatment tests (see Tables 14 and 23). Note that the nepheline peaks are smaller in product S3B than in the other three products made with the same composition, and product S3B was made with SLZ that was screened to remove lumps prior to processing. It is suspected that processing the salt-loaded CWF materials made with SLZ containing lumps of agglomerated SLZ resulted in a less efficient transformation of SLZ to sodalite than usual and in nepheline formation. This does not change the measured effects of composition on the relative amounts of halite and nepheline that are formed.

\subsubsection{Measured CWF Composition}

The uncertainty in the compositions of CWF materials affects the PCT results through the $f(i)$ terms in Eqs. 6 and 7. The total uncertainty in the glass composition was estimated by expressing the cation concentrations as oxides and the chloride concentrations as $\mathrm{NaCl}$ and calculating the total. (The amount of $\mathrm{Na}$ needed to form $\mathrm{NaCl}$ was counted as elemental $\mathrm{Na}$ rather than $\mathrm{Na}_{2} \mathrm{O}$.) The resulting totals are shown in Table 40. The mass balances are $100 \pm 3 \%$ for all products except $\mathrm{S} 3 \mathrm{E}$, which has a total of $91.6 \%$. The $\mathrm{Al}$ and $\mathrm{Na}$ mass fractions determined for product $\mathrm{S} 3 \mathrm{E}$ are all low compared to those for the replicate products $\mathrm{S} 3 \mathrm{~A}$ and $\mathrm{S} 3 \mathrm{C}$, but the $\mathrm{Cl}$ and $\mathrm{K}$ mass fractions are higher and the $\mathrm{B}$ mass fractions are similar (see Table 6). This suggests that the deviation from a $100 \%$ total is due to random uncertainties in the analysis of individual elements rather than a systematic uncertainty, such as in the amount dissolved. The fact that the $\mathrm{B}, \mathrm{Cl}$, and $\mathrm{K}$ concentrations were similar indicates that the amounts of binder glass and salt used to make product G2A were consistent with the amounts in the other products. The low values of $\mathrm{Al}$ and Na suggest that less zeolite was added to product S3E; zeolite contributes about $82 \%$ of the $\mathrm{Al}$ and $60 \%$ of the Na to the CWF. There is no indication of error in making the SLZ used in product S3E, and the free salt measurements are similar to those for the SLZ used in product S3C. The RWS and PCT results for tests with S3E are consistent with those conducted with S3A and S3C. The differences are attributed to errors in the $\mathrm{Al}$ and $\mathrm{Na}$ analyses.

\subsubsection{Quantitation of XRD Peaks}

Although they are used in this report to monitor trends in the presence of sodalite, halite, and nepheline in CWF materials, the areas and heights of XRD peaks used to track sodalite and nepheline were not quantified or calibrated. Halite peaks were quantified by standard addition, and shown to be adequately correlated to the total halite contents of mechanical mixtures of $\mathrm{CWF}$ and $\mathrm{NaCl}$. A nepheline standard was not available for similar calibration of nepheline peaks, and the detection limit is not known. The sodalite content was not quantified because all other peaks were normalized to the sodalite $3.624 \AA$ A peak intensity.

In addition to calibration of the XRD peaks, there is some uncertainty as to whether halite or nepheline was present in a particular material. That is, there was some uncertainty in identifying 
particular peaks as halite, nepheline, or sodalite. The approach taken was to use sodalite as an internal standard and first match peaks to a sodalite reference spectrum based on $d$-spacing and relative peak height. The experimentally measured $d$-spacings were usually shifted from those in the reference spectra, and the same shifts were assumed for neighboring peaks. The assignment of most peaks as sodalite, halite, or nepheline using this method was objective. Subjectivity was required in a few cases as to whether a measured peak should be assigned as nepheline or halite, or as an unidentified peak. In these cases, both the $d$-spacing and intensity of the peak were considered, as well as the relative intensity of the peak in the reference spectrum. Matches to weak peaks were considered fortuitous if peaks matching strong peaks were absent.

The semiquantitative use of the nepheline peaks to indicate the formation of nepheline in the salt-loaded CWF products and the in-growth of nepheline in the heat-treated CWF samples was adequate to meet the objectives of this work, namely, if the phase composition changes with variations in the amounts of salt, zeolite, and binder glass used to make the CWF or with heating, and whether that affects the chemical durability of the CWF. 


\section{CONCLUSIONS}

Conclusion regarding the CWF composition include the following:

The processing range of 10.6 to 11.2 mass\% salt occluded in zeolite $4 \mathrm{~A}\left(3.4\right.$ to $3.6 \mathrm{Cl}^{-}$per formula zeolite) is a conservative control range. As little as $7.5 \mathrm{mass} \%$ salt can be occluded in zeolite $4 \mathrm{~A}\left(2.3 \mathrm{Cl}^{-}\right.$per formula zeolite) without significantly increasing the nepheline content or decreasing the chemical durability measured by the 7-day PCT from that of the nominal composition. The addition of more than the stoichiometric amount of salt (which is about 12\%) will result in the formation of additional halite inclusions, but this does not significantly affect the chemical durability of the CWF. Use of more than 10.7 mass $\%$ occluded salt can increase waste loading without impacting waste form durability.

The processing range of $\mathbf{2 0}$ to $\mathbf{3 0}$ mass \% binder glass is a conservative control range. The glass content does not significantly affect the relative phase composition or chemical durability of the CWF. The use of less than 25 mass\% binder glass can increase waste loading without impacting waste form durability.

CWF made with the target composition (10.7 mass\% salt in SLZ and 25 mass\% binder glass) contains about 1.2 mass\% halite. Analysis of the halite content in the nominal CWF composition by standard addition XRD indicates that halite content is slightly lower that previously thought, which was about 3 mass $\%$.

Minor variations in processing conditions do not affect the phase composition or chemical durability of CWF materials. The presence of hard lumps of SLZ in the mixtures used to make products S1A and S3A or their absence in the sieved mixtures used to make products S1B and S3B did not result in significant differences in the phase compositions measured by XRD or the chemical durability measured with a 7-day PCT. The lumps resulted in the formation of powdery inclusion phases containing sodalite and halite. Though the materials used in these tests did not contain radionuclides, radionuclides that would be present in lumps of actual waste salt would probably not be encapsulated by binder glass. The very small fraction of radionuclides that was in a lump could be released into groundwater faster than the matrix dissolves when the inclusion becomes accessible to water.

The PCT responses of all salt-loaded CWF materials were significantly less than that of the EA glass. Nonconforming waste forms, that is, waste form made under processing conditions outside the established control limits of salt and glass loading, will likely meet acceptance requirements regarding phase composition and chemical durability. It is recommended that description of the CWF in waste form qualification documents include the possible presence of small amounts of nepheline despite the fact that it is not detected by XRD in nominal CWF materials. 
Conclusions regarding heat-treatment of the CWF include the following:

Small amounts of nepheline will form when the CWF is heated. Depending on the time actual waste forms are processed at $915{ }^{\circ} \mathrm{C}$ and their cooling rate after processing, the potential exists that small amounts of nepheline may nucleate and grow during waste form processing. Nepheline may also grow if waste forms are reheated above about $800{ }^{\circ} \mathrm{C}$. However, the presence of nepheline is not detrimental to the chemical durability of the waste form.

The amount of halite in the CWF does not change significantly with heat treatment. The amounts of halite measured by XRD were similar in CWF samples heated at various temperatures for various durations, and in CWF samples that were not heated.

The TTT curve for nepheline formation has a nose point near $850{ }^{\circ} \mathrm{C}$ and 1 day. Nepheline was detected in samples heated at $800{ }^{\circ} \mathrm{C}$ for 52 and 100 hours and at $850{ }^{\circ} \mathrm{C}$ for 28,52 , and 100 hours. A few peaks were matched to nepheline in samples heated at lower temperatures and for shorter durations, but were probably fortuitous. The nepheline contents were not quantified, but are probably $<1$ mass $\%$ based on comparison to sodalite and halite.

The chemical durabilities of heat-treated CWF samples as measured with a 7-day PCT were not affected by heat treatments. The values of $N L(\mathrm{~B})$ for heat-treated samples were the same as those for the CWF source material that was not heated, within experimental uncertainty.

The PCT responses for all heat-treated CWF materials were significantly less than that of the EA glass. Waste form made under processing conditions that fall outside the established control limits of heating and cooling durations, and are considered to be nonconforming with regard to product specifications, will likely meet acceptance requirements regarding phase composition and chemical durability. It is recommended that description of the CWF include the possible presence of small amounts of nepheline. 
Table 1. Calculated batch compositions of salt-loaded CWF materials

\begin{tabular}{|c|c|c|c|c|c|}
\hline \multirow{2}{*}{ Material ID } & \multicolumn{2}{|c|}{ Target composition } & \multicolumn{2}{c|}{ Mass required for 900 g CWF, g } \\
\cline { 2 - 6 } & $\begin{array}{c}\text { Mass\% salt in } \\
\text { SLZ }\end{array}$ & $\begin{array}{c}\text { Mass\% glass in } \\
\text { CWF }\end{array}$ & Salt & Zeolite & Glass \\
\hline S1 & 5.0 & 25.0 & 33.8 & 641.3 & 225.0 \\
\hline S2 & 7.5 & 25.0 & 50.6 & 624.4 & 225.0 \\
\hline S3 & 10.7 & 25.0 & 72.2 & 602.8 & 225.0 \\
\hline S4 & 12.5 & 25.0 & 84.4 & 590.6 & 225.0 \\
\hline S5 & 15.0 & 25.0 & 101.3 & 573.8 & 225.0 \\
\hline G1 & 10.7 & 20.0 & 77.0 & 643.0 & 180.0 \\
\hline G2 & 10.7 & 22.5 & 74.6 & 622.9 & 202.5 \\
\hline G4 & 10.7 & 27.5 & 69.8 & 582.7 & 247.5 \\
\hline G5 & 10.7 & 30.0 & 67.4 & 562.6 & 270.0 \\
\hline
\end{tabular}

Table 2. Salt composition, in mass\%

\begin{tabular}{|c|c|c|}
\hline Component & $\begin{array}{c}\text { Simulated } \\
300 \text { driver salt } \\
\text { composition }^{2}\end{array}$ & $\begin{array}{c}300 \text { driver salt } \\
\text { as-batched } \\
\text { composition }\end{array}$ \\
\hline $\mathrm{NaCl}$ & 14.9 & 14.95 \\
\hline $\mathrm{RbCl}$ & 0.330 & 0.33 \\
\hline $\mathrm{SrCl}_{2}$ & 1.01 & 1.00 \\
\hline $\mathrm{YCl}$ & 0.700 & 0.70 \\
\hline $\mathrm{CsCl}$ & 2.50 & 2.51 \\
\hline $\mathrm{BaCl}_{2}$ & 1.20 & 1.20 \\
\hline $\mathrm{LaCl}_{3}$ & 1.22 & 1.22 \\
\hline $\mathrm{CeCl}_{3}$ & 2.33 & 2.33 \\
\hline $\mathrm{PrCl}_{3}$ & 1.15 & 1.15 \\
\hline $\mathrm{NdCl}_{3}$ & 3.89 & 3.90 \\
\hline $\mathrm{SmCl}$ & 0.686 & 0.69 \\
\hline $\mathrm{EuCl}$ & 0.047 & 0.05 \\
\hline $\mathrm{KBr}$ & 0.023 & excluded \\
\hline $\mathrm{LiCl}_{3} \mathrm{KCl}$ & 69.7 & 69.80 \\
\hline $\mathrm{Kl}$ & 0.154 & 0.15 \\
\hline $\mathrm{PmCl}{ }_{3}$ & 0.110 & excluded \\
\hline \hline $\mathrm{Total}$ & 99.89 & 100.00 \\
\hline
\end{tabular}

${ }^{a}$ Reference salt composition representing treatment of 300 driver fuel rods (Goff et al. 1999, Table 5).

${ }^{\mathrm{b}}$ Eutectic mixture. 
Table 3. Particle size distributions of zeolite and binder glass, in mass $\%$

\begin{tabular}{|c|c|c|c|c|}
\hline $\begin{array}{c}\text { Mesh size } \\
\text { range }^{a}\end{array}$ & Size range, $\mu \mathrm{m}$ & $\begin{array}{c}\text { Zeolite } \\
\text { MPE-1 }\end{array}$ & $\begin{array}{c}\text { Zeolite } \\
\text { MPE-070904 }\end{array}$ & Binder glass \\
\hline-325 & $<45$ & 4 & 5 & 22 \\
\hline$-200+325$ & $45-75$ & 14 & 5 & 23 \\
\hline$-170+200$ & $75-90$ & 11 & 5 & 13 \\
\hline$-100+170$ & $90-150$ & 42 & 21 & 34 \\
\hline$-70+100$ & $150-212$ & 25 & 39 & 8 \\
\hline$-60+70$ & $212-250$ & 3.4 & 13 & 0 \\
\hline$-50+60$ & $250-300$ & 0.2 & 7 & 0 \\
\hline+50 & $>300$ & 0.4 & 5 & 0 \\
\hline
\end{tabular}

${ }^{\mathrm{a}}$ US Series designation.

Table 4. Processing data for salt-loaded CWF materials

\begin{tabular}{|c|c|c|c|c|c|c|c|c|}
\hline $\begin{array}{c}\text { Material } \\
\text { ID }\end{array}$ & Zeolite source & $\begin{array}{l}\text { Heating } \\
\text { program } \\
\text { number }\end{array}$ & $\begin{array}{c}\text { Salt } \\
\text { occlusion } \\
\text { time } \\
\text { h }\end{array}$ & $\begin{array}{c}\text { Cool time } \\
\text { while } \\
\text { rotating, } \\
\mathrm{h}\end{array}$ & $\begin{array}{l}\text { Temp. when } \\
\text { rotation } \\
\text { stopped, } \\
{ }^{\circ} \mathrm{C}\end{array}$ & $\begin{array}{c}\text { Glass } \\
\text { mixing } \\
\text { time } \\
h\end{array}$ & $\begin{array}{l}\text { SLZ/glass } \\
\text { batch } \\
\text { number }\end{array}$ & Product ID \\
\hline S1 & MPE-1 \#1 & 1 & 18 & Not reported & Not reported & 18 & S1/1 & $A \& B$ \\
\hline S2 & MPE-1 \#4 \& \#5 & 2 & 24 & 4.5 & 250 & 5.2 & $\mathrm{~S} 2 / 2$ & C \\
\hline S3 & MPE-1 \#3 \& \#4 & 1 & 22.7 & 24.3 & 25 & 20 & S3/1 & $A \& B$ \\
\hline S3 & MPE-1 \#4 & 2 & 17.5 & 6.5 & 190 & 18.5 & $\mathrm{~S} 3 / 2$ & C \\
\hline S3 & MPE-070904 \#5 & 2 & 22.5 & 4.5 & 251 & 4 & S3/3 & $E$ \\
\hline S4 & MPE-1 \#6 & 2 & 23.5 & 5 & 256 & 4 & $\mathrm{~S} 4 / 1$ & $\mathrm{~A}$ \\
\hline S5 & MPE-1 \#5, \#6, \#7 & 2 & 25.5 & 3.3 & 306 & 4 & $\mathrm{~S} 5 / 1$ & $\mathrm{~B}$ \\
\hline G1 & MPE-1 \#1 \& \#7 & 2 & 23.3 & 2.8 & 330 & 3.5 & G1/1 & $A$ \\
\hline G2 & MPE-1 \#1 \& \#9 & 2 & 21.7 & 3.5 & 276 & 3.3 & $\mathrm{G} 2 / 1$ & A \\
\hline G4 & MPE-1 \#8 \& \#9 & 2 & 22.3 & 4.8 & 248 & 4 & $\mathrm{G} 4 / 1$ & $\mathrm{~A}$ \\
\hline G5 & MPE-1 \#8 \& \#11 & 2 & 22.5 & 3.5 & 295 & 3 & G5/1 & A \\
\hline
\end{tabular}

\begin{tabular}{|c|c|c|c|c|c|c|c|c|}
\hline \multirow{2}{*}{$\begin{array}{c}\text { Material } \\
\text { ID }\end{array}$} & \multirow{2}{*}{$\begin{array}{c}\text { Actual } \\
\text { \% salt in } \\
\text { SLZ }\end{array}$} & \multirow{2}{*}{$\begin{array}{c}\text { Actual } \\
\text { \% glass in } \\
\text { CWF }\end{array}$} & \multicolumn{4}{|c|}{ Mass in mixture, g } & \multicolumn{3}{c|}{ Mass fraction in CWF } \\
\cline { 7 - 10 } & & Zeolite & Salt & $\begin{array}{c}\text { Binder } \\
\text { glass }\end{array}$ & Zeolite & \multicolumn{2}{c|}{$\begin{array}{c}\text { Salt } \\
\text { Binder } \\
\text { glass }\end{array}$} \\
\hline $\begin{array}{c}\text { S1A and } \\
\text { S1B }\end{array}$ & 5.00 & 25.00 & 641.25 & 33.75 & 225.00 & 0.7125 & 0.0375 & 0.2500 \\
\hline S2C & 7.50 & 25.00 & 624.38 & 50.65 & 225.02 & 0.6937 & 0.0563 & 0.2500 \\
\hline $\begin{array}{c}\text { S3A and } \\
\text { S3B }\end{array}$ & 10.70 & 25.00 & 602.78 & 72.22 & 225.01 & 0.6697 & 0.0802 & 0.2500 \\
\hline S3C & 10.70 & 25.00 & 602.79 & 72.19 & 224.99 & 0.6698 & 0.0802 & 0.2500 \\
\hline S3E & 10.70 & 25.04 & 602.77 & 72.22 & 225.43 & 0.6694 & 0.0802 & 0.2504 \\
\hline S4A & 12.50 & 25.00 & 590.62 & 84.36 & 225.04 & 0.6562 & 0.0937 & 0.2500 \\
\hline S5B & 15.00 & 25.00 & 573.75 & 101.25 & 225.00 & 0.6375 & 0.1125 & 0.2500 \\
\hline G1A & 10.70 & 20.01 & 642.98 & 77.05 & 180.16 & 0.7143 & 0.0856 & 0.2001 \\
\hline G2A & 10.70 & 22.52 & 622.87 & 74.63 & 202.71 & 0.6919 & 0.0829 & 0.2252 \\
\hline G4A & 10.70 & 27.54 & 582.68 & 69.82 & 247.97 & 0.6471 & 0.0775 & 0.2754 \\
\hline G5A & 10.70 & 30.00 & 562.60 & 67.40 & 270.00 & 0.6251 & 0.0749 & 0.3000 \\
\hline
\end{tabular}


Table 5. Compositions of glass, salt, and zeolite components, and as-batched compositions of salt-loaded CWF materials, in mass\%

\begin{tabular}{|c|c|c|c|c|c|c|c|c|c|c|c|c|c|c|}
\hline & Glass & Salt & Zeolite & $\begin{array}{l}\text { S1A } \\
\text { and } \\
\text { S1B }\end{array}$ & S2C & $\begin{array}{l}\mathrm{S} 3 \mathrm{~A} \\
\text { and } \\
\text { S3B }\end{array}$ & S3C & S3E & S4A & S5B & G1A & G2A & G4A & G5A \\
\hline $\mathrm{Al}$ & 3.95 & 0.00 & 18.83 & 14.40 & 14.05 & 13.60 & 13.60 & 13.59 & 13.34 & 12.99 & 14.24 & 13.92 & 13.27 & 12.96 \\
\hline $\mathrm{B}$ & 5.99 & 0.00 & 0.00 & 1.50 & 1.50 & 1.50 & 1.50 & 1.50 & 1.50 & 1.50 & 1.20 & 1.35 & 1.65 & 1.80 \\
\hline $\mathrm{Ba}$ & 0.02 & 0.79 & 0.01 & 0.04 & 0.06 & 0.08 & 0.08 & 0.08 & 0.09 & 0.10 & 0.08 & 0.08 & 0.07 & 0.07 \\
\hline $\mathrm{Ca}$ & 0.93 & & 0.03 & 0.25 & 0.25 & 0.25 & 0.25 & 0.25 & 0.25 & 0.25 & 0.21 & 0.23 & 0.28 & 0.30 \\
\hline $\mathrm{Cl}$ & 0.00 & 59.45 & 0.00 & 2.23 & 3.35 & 4.77 & 4.77 & 4.77 & 5.57 & 6.69 & 5.09 & 4.93 & 4.61 & 4.45 \\
\hline $\mathrm{Ce}$ & & 1.22 & & 0.05 & 0.07 & 0.10 & 0.10 & 0.10 & 0.11 & 0.14 & 0.10 & 0.10 & 0.09 & 0.09 \\
\hline Cs & 0.00 & 1.82 & 0.00 & 0.07 & 0.10 & 0.15 & 0.15 & 0.15 & 0.17 & 0.20 & 0.16 & 0.15 & 0.14 & 0.14 \\
\hline $\mathrm{Eu}$ & & 0.03 & & 0.00 & 0.00 & 0.00 & 0.00 & 0.00 & 0.00 & 0.00 & 0.00 & 0.00 & 0.00 & 0.00 \\
\hline I & 0.00 & 0.12 & 0.00 & 0.00 & 0.01 & 0.01 & 0.01 & 0.01 & 0.01 & 0.01 & 0.01 & 0.01 & 0.01 & 0.01 \\
\hline $\mathrm{K}$ & 0.37 & 21.08 & 0.04 & 0.91 & 1.31 & 1.81 & 1.81 & 1.81 & 2.09 & 2.49 & 1.91 & 1.86 & 1.76 & 1.71 \\
\hline La & & 0.64 & & 0.02 & 0.04 & 0.05 & 0.05 & 0.05 & 0.06 & 0.07 & 0.05 & 0.05 & 0.05 & 0.05 \\
\hline $\mathrm{Li}$ & 0.00 & 5.49 & 0.00 & 0.21 & 0.31 & 0.44 & 0.44 & 0.44 & 0.52 & 0.62 & 0.47 & 0.46 & 0.43 & 0.41 \\
\hline $\mathrm{Na}$ & 4.83 & 5.23 & 14.87 & 12.00 & 11.82 & 11.59 & 11.59 & 11.58 & 11.46 & 11.28 & 12.04 & 11.81 & 11.36 & 11.14 \\
\hline $\mathrm{Nd}$ & & 1.96 & & 0.07 & 0.11 & 0.16 & 0.16 & 0.16 & 0.18 & 0.22 & 0.17 & 0.16 & 0.15 & 0.15 \\
\hline $\mathrm{Pr}$ & & 0.54 & & 0.02 & 0.03 & 0.04 & 0.04 & 0.04 & 0.05 & 0.06 & 0.05 & 0.04 & 0.04 & 0.04 \\
\hline $\mathrm{Rb}$ & & 0.23 & & 0.01 & 0.01 & 0.02 & 0.02 & 0.02 & 0.02 & 0.03 & 0.02 & 0.02 & 0.02 & 0.02 \\
\hline $\mathrm{Si}$ & 29.50 & 0.00 & 18.70 & 20.70 & 20.35 & 19.90 & 19.90 & 19.90 & 19.65 & 19.30 & 19.26 & 19.58 & 20.22 & 20.54 \\
\hline $\mathrm{Sm}$ & & 0.35 & & 0.01 & 0.02 & 0.03 & 0.03 & 0.03 & 0.03 & 0.04 & 0.03 & 0.03 & 0.03 & 0.03 \\
\hline $\mathrm{Sr}$ & 0.02 & 0.05 & 0.00 & 0.01 & 0.01 & 0.01 & 0.01 & 0.01 & 0.01 & 0.01 & 0.01 & 0.01 & 0.01 & 0.01 \\
\hline $\mathrm{Y}$ & & 0.19 & & 0.01 & 0.01 & 0.02 & 0.02 & 0.02 & 0.02 & 0.02 & 0.02 & 0.02 & 0.01 & 0.01 \\
\hline \multicolumn{4}{|c|}{ Number of $\mathrm{Cl}^{-}$ions per unit cell zeolite } & 1.51 & 2.32 & 3.43 & 3.43 & 3.43 & 4.09 & 5.05 & 3.43 & 3.43 & 3.43 & 3.43 \\
\hline
\end{tabular}


Table 6. Measured compositions of salt-loaded CWF materials and LRM glass standard

\begin{tabular}{|c|c|c|c|c|c|c|c|c|c|c|c|}
\hline \multirow{2}{*}{ CWF product } & \multirow{2}{*}{$\begin{array}{l}\text { Mass dissolved } \\
\text { for analysis, } g\end{array}$} & \multicolumn{2}{|c|}{$\mathrm{Al}$} & \multicolumn{2}{|c|}{$B$} & \multicolumn{2}{|c|}{$\mathrm{Ba}$} & \multicolumn{2}{|c|}{$\mathrm{Ca}$} & \multicolumn{2}{|c|}{$\mathrm{Cl}$} \\
\hline & & $\mathrm{mg} / \mathrm{L}$ & $f(\mathrm{Al})$ & $\mathrm{mg} / \mathrm{L}$ & $f(B)$ & $\mathrm{mg} / \mathrm{L}$ & $f(\mathrm{Ba})$ & $\mathrm{mg} / \mathrm{L}$ & $f(\mathrm{Ca})$ & Mass $\%$ & $f(\mathrm{Cl})$ \\
\hline S1A & 0.0531 & 158 & 0.149 & 14.6 & 0.0138 & 2.39 & 0.00225 & 1.85 & 0.00174 & 2.83 & 0.0283 \\
\hline S2C & 0.0512 & 146 & 0.143 & 14.8 & 0.0145 & 2.48 & 0.00242 & 1.84 & 0.00180 & 3.54 & 0.0354 \\
\hline S3A & 0.0505 & 138 & 0.137 & 14.5 & 0.0144 & 2.57 & 0.00255 & 1.79 & 0.00177 & 4.38 & 0.0438 \\
\hline S3C & 0.0516 & 142 & 0.138 & 15.1 & 0.0146 & 2.69 & 0.00261 & 1.80 & 0.00174 & 4.37 & 0.0437 \\
\hline S3E & 0.0518 & 125 & 0.121 & 15.1 & 0.0146 & 2.58 & 0.00249 & 1.80 & 0.00174 & 4.66 & 0.0466 \\
\hline S4A & 0.0502 & 138 & 0.137 & 15.4 & 0.0153 & 2.70 & 0.00269 & 1.77 & 0.00176 & 4.97 & 0.0497 \\
\hline S4A dup. ${ }^{a}$ & 0.0509 & 136 & 0.134 & 15.3 & 0.0150 & 2.64 & 0.00260 & 1.83 & 0.00180 & 5.09 & 0.0509 \\
\hline S5B & 0.0504 & 134 & 0.133 & 14.8 & 0.0147 & 2.86 & 0.00284 & 1.75 & 0.00174 & 5.43 & 0.0543 \\
\hline G1A & 0.0507 & 145 & 0.143 & 12.0 & 0.0118 & 2.33 & 0.00230 & 1.57 & 0.00155 & 5.99 & 0.0599 \\
\hline G2A & 0.0515 & 149 & 0.144 & 13.5 & 0.0131 & 2.44 & 0.00237 & 1.72 & 0.00167 & 5.28 & 0.0528 \\
\hline G4A & 0.0520 & 147 & 0.141 & 17.4 & 0.0167 & 2.95 & 0.00284 & 1.84 & 0.00177 & 4.40 & 0.0440 \\
\hline G5A & 0.0515 & 131 & 0.127 & 18.0 & 0.0175 & 3.04 & 0.00295 & 2.00 & 0.00194 & 4.23 & 0.0423 \\
\hline LRM & 0.0508 & 48.8 & 0.0481 & 23.2 & 0.0228 & 0.00006 & 0.00000 & 3.21 & 0.00316 & 0 & 0.0000 \\
\hline LRM std. $^{b}$ & & & $\begin{array}{c}0.0503 \pm \\
0.0053\end{array}$ & & $\begin{array}{c}0.0244 \pm \\
0.0030\end{array}$ & & 0.0000 & & $\begin{array}{c}0.0039 \pm \\
0.0017\end{array}$ & & $n a^{c}$ \\
\hline
\end{tabular}

\begin{tabular}{|c|c|c|c|c|c|c|c|c|c|c|c|c|}
\hline & \multicolumn{2}{|c|}{$\mathrm{Ce}$} & \multicolumn{2}{|c|}{$\mathrm{Cr}$} & \multicolumn{2}{|c|}{ Cs } & \multicolumn{2}{|c|}{ Eu } & \multicolumn{2}{|c|}{$\mathrm{Fe}$} & \multicolumn{2}{|c|}{$\mathrm{K}$} \\
\hline & $\mathrm{mg} / \mathrm{L}$ & $f(\mathrm{Ce})$ & $\mathrm{mg} / \mathrm{L}$ & $f(\mathrm{Cr})$ & $\mathrm{mg} / \mathrm{L}$ & $f(\mathrm{Cs})$ & $\mathrm{mg} / \mathrm{L}$ & $f(\mathrm{Eu})$ & $\mathrm{mg} / \mathrm{L}$ & $f(\mathrm{Fe})$ & $\mathrm{mg} / \mathrm{L}$ & $f(\mathrm{~K})$ \\
\hline S1A & 0.353 & 0.000333 & 0.347 & 0.000327 & 0.681 & 0.000642 & 0.00894 & 0.000008 & 1.49 & 0.00140 & 9.12 & 0.00859 \\
\hline S2C & 0.145 & 0.000142 & 0.229 & 0.000224 & 1.05 & 0.00103 & 0.00622 & 0.000006 & 1.43 & 0.00140 & 11.4 & 0.0111 \\
\hline S3A & 0.129 & 0.000128 & 0.375 & 0.000371 & 1.41 & 0.00140 & 0.00683 & 0.000007 & 1.62 & 0.00160 & 15.0 & 0.014 \\
\hline S3C & 0.137 & 0.000133 & 0.306 & 0.000297 & 1.51 & 0.00146 & 0.00692 & 0.000007 & 1.58 & 0.00153 & 15.5 & 0.01502 \\
\hline S3E & 0.129 & 0.000124 & 0.428 & 0.000413 & 1.44 & 0.00139 & 0.00671 & 0.000006 & 1.78 & 0.00172 & 15.4 & 0.0149 \\
\hline S4A & 0.117 & 0.000116 & 0.477 & 0.000475 & 1.67 & 0.00166 & 0.00564 & 0.000006 & 1.64 & 0.00163 & 17.4 & 0.0173 \\
\hline S4A dup. & 0.123 & 0.000121 & 0.469 & 0.000461 & 1.62 & 0.00159 & 0.00506 & 0.000005 & 1.87 & 0.00184 & 17.1 & 0.0168 \\
\hline S5B & 0.12 & 0.000119 & 0.561 & 0.000556 & 2.02 & 0.00200 & 0.00626 & 0.000006 & 1.98 & 0.00196 & 20.1 & 0.0199 \\
\hline G1A & 0.129 & 0.000127 & 0.798 & 0.000787 & 2.03 & 0.00200 & 0.00723 & 0.000007 & 2.06 & 0.00203 & 21.0 & 0.0207 \\
\hline G2A & 0.107 & 0.000104 & 0.653 & 0.000633 & 1.78 & 0.00173 & 0.00479 & 0.000005 & 1.60 & 0.00155 & 19.3 & 0.0187 \\
\hline G4A & 0.15 & 0.000144 & 0.205 & 0.000197 & 1.50 & 0.00144 & 0.00547 & 0.000005 & 1.23 & 0.00118 & 15.3 & 0.0147 \\
\hline G5A & 0.153 & 0.000148 & 0.329 & 0.000319 & 1.41 & 0.00137 & 0.00541 & 0.000005 & 1.44 & 0.00140 & 14.6 & 0.0142 \\
\hline LRM & 0.00012 & 0.000000 & 1.28 & 0.00126 & 0.00002 & 0.000000 & 0.00002 & 0.000000 & 9.37 & 0.00923 & 7.53 & 0.00741 \\
\hline LRM std. & & na & & 0.0013 & & na & & na & & $\begin{array}{c}0.0097 \pm \\
0.0037\end{array}$ & & $\begin{array}{c}0.012 \pm \\
0.012\end{array}$ \\
\hline
\end{tabular}


Table 6. (continued)

\begin{tabular}{|c|c|c|c|c|c|c|c|c|c|c|c|c|}
\hline & \multicolumn{2}{|c|}{ La } & \multicolumn{2}{|c|}{$\mathrm{Li}$} & \multicolumn{2}{|c|}{$\mathrm{Mg}$} & \multicolumn{2}{|c|}{$\mathrm{Mn}$} & \multicolumn{2}{|c|}{ Mo } & \multicolumn{2}{|c|}{$\mathrm{Na}$} \\
\hline & $\mathrm{mg} / \mathrm{L}$ & $f(\mathrm{La})$ & $\mathrm{mg} / \mathrm{L}$ & $f(\mathrm{Li})$ & $\mathrm{mg} / \mathrm{L}$ & $f(\mathrm{Mg})$ & $\mathrm{mg} / \mathrm{L}$ & $f(\mathrm{Mn})$ & $\mathrm{mg} / \mathrm{L}$ & $f(\mathrm{Mo})$ & $\mathrm{mg} / \mathrm{L}$ & $f(\mathrm{Na})$ \\
\hline S1A & 0.196 & 0.00018 & 1.86 & 0.00175 & 0.0658 & 0.00006 & 0.0354 & 0.00003 & 0.00988 & 0.00001 & 138 & 0.130 \\
\hline $\mathrm{S} 2 \mathrm{C}$ & 0.0421 & 0.00004 & 2.48 & 0.00242 & 0.0583 & 0.00006 & 0.0525 & 0.00005 & 0.00665 & 0.00001 & 131 & 0.128 \\
\hline S3A & 0.0406 & 0.00004 & 3.43 & 0.00340 & 0.0584 & 0.00006 & 0.0606 & 0.00006 & 0.00861 & 0.00001 & 124 & 0.123 \\
\hline S3C & 0.038 & 0.00004 & 3.49 & 0.00338 & 0.0594 & 0.00006 & 0.0443 & 0.00004 & 0.00796 & 0.00001 & 129 & 0.125 \\
\hline S3E & 0.0397 & 0.00004 & 3.68 & 0.00355 & 0.0599 & 0.00006 & 0.0829 & 0.00008 & 0.00736 & 0.00001 & 115 & 0.111 \\
\hline S4A & 0.0347 & 0.00003 & 4.01 & 0.00399 & 0.0587 & 0.00006 & 0.0923 & 0.00009 & 0.0104 & 0.00001 & 125 & 0.124 \\
\hline S4A dup. & 0.0359 & 0.00004 & 3.93 & 0.00386 & 0.0639 & 0.00006 & 0.0948 & 0.00009 & 0.0124 & 0.00001 & 121 & 0.119 \\
\hline S5B & 0.0389 & 0.00004 & 5.09 & 0.00505 & 0.0596 & 0.00006 & 0.0775 & 0.00008 & 0.0114 & 0.00001 & 117 & 0.116 \\
\hline G1A & 0.0402 & 0.00004 & 5.49 & 0.00542 & 0.0544 & 0.00005 & 0.104 & 0.00010 & 0.0126 & 0.00001 & 128 & 0.126 \\
\hline G2A & 0.0375 & 0.00004 & 4.81 & 0.00466 & 0.0607 & 0.00006 & 0.0901 & 0.00009 & 0.00742 & 0.00001 & 133 & 0.129 \\
\hline G4A & 0.0495 & 0.00005 & 3.38 & 0.00325 & 0.0630 & 0.00006 & 0.0397 & 0.00004 & 0.00528 & 0.00001 & 128 & 0.123 \\
\hline G5A & 0.0454 & 0.00004 & 3.22 & 0.00312 & 0.0656 & 0.00006 & 0.0394 & 0.00004 & 0.00762 & 0.00001 & 121 & 0.117 \\
\hline LRM & 0.0664 & 0.00007 & 0.457 & 0.00045 & 0.599 & 0.00059 & 0.496 & 0.00049 & 0.728 & 0.00072 & 147 & 0.145 \\
\hline LRM std. & & 0.0002 & & 0.00051 & & 0.00060 & & 0.00050 & & 0.00070 & & $\begin{array}{c}0.148 \pm \\
0.025\end{array}$ \\
\hline
\end{tabular}

\begin{tabular}{|c|c|c|c|c|c|c|c|c|c|c|c|c|}
\hline & \multicolumn{2}{|c|}{$\mathrm{Ni}$} & \multicolumn{2}{|c|}{$\mathrm{Nd}$} & \multicolumn{2}{|c|}{$P$} & \multicolumn{2}{|c|}{$\mathrm{Pb}$} & \multicolumn{2}{|c|}{$\mathrm{Pr}$} & \multicolumn{2}{|c|}{$\mathrm{Rb}$} \\
\hline & $\mathrm{mg} / \mathrm{L}$ & $f(\mathrm{Ni})$ & $\mathrm{mg} / \mathrm{L}$ & $f(\mathrm{Nd})$ & $\mathrm{mg} / \mathrm{L}$ & $f(\mathrm{P})$ & $\mathrm{mg} / \mathrm{L}$ & $f(\mathrm{~Pb})$ & $\mathrm{mg} / \mathrm{L}$ & $f(\operatorname{Pr})$ & $\mathrm{mg} / \mathrm{L}$ & $f(\mathrm{Rb})$ \\
\hline S1A & 0.124 & 0.00012 & 0.547 & 0.00052 & 0.0656 & 0.00006 & 0.00712 & 0.00001 & 0.171 & 0.00016 & 0.0712 & 0.00007 \\
\hline S2C & 0.0855 & 0.00008 & 0.383 & 0.00037 & 0.0694 & 0.00007 & 0.00736 & 0.00001 & 0.0890 & 0.00009 & 0.102 & 0.00010 \\
\hline S3A & 0.123 & 0.00012 & 0.356 & 0.00035 & 0.0650 & 0.00006 & 0.00674 & 0.00001 & 0.0860 & 0.00009 & 0.166 & 0.00016 \\
\hline S3C & 0.108 & 0.00010 & 0.388 & 0.00038 & 0.0646 & 0.00006 & 0.00409 & 0.00000 & 0.0930 & 0.00009 & 0.168 & 0.00016 \\
\hline S3E & 0.136 & 0.00013 & 0.370 & 0.00036 & 0.0650 & 0.00006 & 0.00632 & 0.00001 & 0.0855 & 0.00008 & 0.169 & 0.00016 \\
\hline S4A & 0.239 & 0.00024 & 0.338 & 0.00034 & 0.0679 & 0.00007 & 0.0123 & 0.00001 & 0.0808 & 0.00008 & 0.193 & 0.00019 \\
\hline S4A dup. & 0.282 & 0.00028 & 0.360 & 0.00035 & 0.0710 & 0.00007 & 0.0101 & 0.00001 & 0.0809 & 0.00008 & 0.192 & 0.00019 \\
\hline S5B & 0.245 & 0.00024 & 0.300 & 0.00030 & 0.0752 & 0.00007 & 0.00694 & 0.00001 & 0.0747 & 0.00007 & 0.228 & 0.00023 \\
\hline G1A & 0.290 & 0.00029 & 0.377 & 0.00037 & 0.0623 & 0.00006 & 0.00369 & 0.00000 & 0.0811 & 0.00008 & 0.240 & 0.00024 \\
\hline G2A & 0.112 & 0.00011 & 0.278 & 0.00027 & 0.0619 & 0.00006 & 0.00409 & 0.00000 & 0.0594 & 0.00006 & 0.226 & 0.00022 \\
\hline G4A & 0.0892 & 0.00009 & 0.414 & 0.00040 & 0.0737 & 0.00007 & 0.00473 & 0.00000 & 0.0985 & 0.00009 & 0.168 & 0.00016 \\
\hline G5A & 0.121 & 0.00012 & 0.426 & 0.00041 & 0.0780 & 0.00008 & 0.00509 & 0.00000 & 0.0977 & 0.00009 & 0.162 & 0.00016 \\
\hline LRM & 1.56 & 0.00154 & 0.0004 & 0.00000 & 3.05 & 0.00300 & 0.83 & 0.00082 & 0.00004 & 0.00000 & 0.00499 & 0.00000 \\
\hline LRM std. & & 0.0015 & & na & & 0.0024 & & 0.00090 & & na & & na \\
\hline
\end{tabular}


Table 6. (continued)

\begin{tabular}{|c|c|c|c|c|c|c|c|c|c|c|c|c|}
\hline & \multicolumn{2}{|c|}{$\mathrm{Si}$} & \multicolumn{2}{|c|}{$\mathrm{Sm}$} & \multicolumn{2}{|c|}{$\mathrm{Sr}$} & \multicolumn{2}{|c|}{$\mathrm{Ti}$} & \multicolumn{2}{|c|}{$\mathrm{Y}$} & \multicolumn{2}{|c|}{$\mathrm{Zr}$} \\
\hline & $\mathrm{mg} / \mathrm{L}$ & $f(\mathrm{Si})$ & $\mathrm{mg} / \mathrm{L}$ & $f(\mathrm{Sm})$ & $\mathrm{mg} / \mathrm{L}$ & $f(\mathrm{Sr})$ & $\mathrm{mg} / \mathrm{L}$ & $f(\mathrm{Ti})$ & $\mathrm{mg} / \mathrm{L}$ & $f(Y)$ & $\mathrm{mg} / \mathrm{L}$ & $f(Z r)$ \\
\hline S1A & 215 & 0.203 & 0.104 & 0.00010 & 0.343 & 0.00032 & 1.29 & 0.00122 & 0.0884 & 0.00008 & 0.302 & 0.00028 \\
\hline S2C & 209 & 0.204 & 0.0926 & 0.00009 & 0.424 & 0.00041 & 1.27 & 0.00124 & 0.0324 & 0.00003 & 0.289 & 0.00028 \\
\hline S3A & 199 & 0.197 & 0.0866 & 0.00009 & 0.524 & 0.00052 & 1.21 & 0.00120 & 0.0297 & 0.00003 & 0.282 & 0.00028 \\
\hline S3C & 206 & 0.200 & 0.0958 & 0.00009 & 0.529 & 0.00051 & 1.25 & 0.00121 & 0.0290 & 0.00003 & 0.290 & 0.00028 \\
\hline S3E & 199 & 0.192 & 0.0946 & 0.00009 & 0.529 & 0.00051 & 1.23 & 0.00119 & 0.0331 & 0.00003 & 0.291 & 0.00028 \\
\hline S4A & 204 & 0.203 & 0.0836 & 0.00008 & 0.568 & 0.00057 & 1.21 & 0.00120 & 0.0261 & 0.00003 & 0.284 & 0.00028 \\
\hline S4A dup. & 202 & 0.199 & 0.0893 & 0.00009 & 0.569 & 0.00056 & 1.20 & 0.00118 & 0.0254 & 0.00002 & 0.285 & 0.00028 \\
\hline S5B & 205 & 0.203 & 0.0858 & 0.00009 & 0.649 & 0.00064 & 1.16 & 0.00115 & 0.0454 & 0.00005 & 0.284 & 0.00028 \\
\hline G1A & 201 & 0.198 & 0.0947 & 0.00009 & 0.636 & 0.00063 & 1.16 & 0.00114 & 0.0357 & 0.00004 & 0.237 & 0.00023 \\
\hline G2A & 202 & 0.196 & 0.0822 & 0.00008 & 0.671 & 0.00065 & 1.21 & 0.00117 & 0.0492 & 0.00005 & 0.262 & 0.00025 \\
\hline G4A & 226 & 0.217 & 0.0996 & 0.00010 & 0.535 & 0.00051 & 1.26 & 0.00121 & 0.0392 & 0.00004 & 0.324 & 0.00031 \\
\hline G5A & 214 & 0.208 & 0.0996 & 0.00010 & 0.541 & 0.00052 & 1.19 & 0.00115 & 0.0300 & 0.00003 & 0.344 & 0.00033 \\
\hline LRM & 231 & 0.227 & 0.00022 & 0.00000 & 0.0247 & 0.00002 & 0.595 & 0.00059 & 0.0149 & 0.00001 & 6.58 & 0.00648 \\
\hline LRM std. & & $\begin{array}{c}0.253 \pm \\
0.019\end{array}$ & & na & & na & & 0.0006 & & na & & $\begin{array}{c}0.0069 \pm \\
0.0014\end{array}$ \\
\hline
\end{tabular}

${ }^{a}$ Duplicate dissolution and analysis of salt-loaded CWF material S4A.

${ }^{b}$ Reproducibility for compositional analysis of LRM standard test material measured in interlaboratory study (Ebert and Wolf, 2000).

${ }^{\mathrm{c}}$ Content of this component in LRM glass was not analyzed in the interlaboratory study. 
Table 7. Data for density measurement and calculated specific surface area

\begin{tabular}{|c|c|c|c|c|c|c|c|c|c|c|c|c|}
\hline & S1A & S2C & S3A & S3C & S3E & S4B & S5A & G1A & G2A & G4A & G5A & $\begin{array}{c}\text { No } \\
\text { heat }\end{array}$ \\
\hline Mass of volumetric flask, $\mathrm{g}$ & $35.01^{a}$ & $34.88^{b}$ & $35.26^{c}$ & $35.01^{a}$ & $34.88^{b}$ & $35.26^{c}$ & $35.01^{a}$ & $34.88^{b}$ & $35.26^{c}$ & $35.01^{a}$ & $34.88^{b}$ & $35.26^{\mathrm{c}}$ \\
\hline Volumetric flask + CWF, g & 38.29 & 37.93 & 38.34 & 38.46 & 38.03 & 38.45 & 38.16 & 37.95 & 38.54 & 38.18 & 38.14 & 38.44 \\
\hline Mass CWF, g & 3.28 & 3.05 & 3.08 & 3.45 & 3.15 & 3.19 & 3.15 & 3.07 & 3.28 & 3.17 & 3.26 & 3.18 \\
\hline $\begin{array}{l}\text { Volumetric flask + CWF } \\
+ \text { DIW, g }\end{array}$ & 86.46 & 86.20 & 86.54 & 86.59 & 86.27 & 86.67 & 86.44 & 86.14 & 86.78 & 86.40 & 86.29 & 86.57 \\
\hline Mass DIW added, g & 48.17 & 48.27 & 48.20 & 48.13 & 48.24 & 48.22 & 48.28 & 48.19 & 48.24 & 48.22 & 48.15 & 48.13 \\
\hline $\begin{array}{l}\text { Volume of volumetric flask, } \\
\mathrm{mL}\end{array}$ & 49.94 & 49.92 & 49.99 & 49.98 & 50.00 & 49.97 & 49.98 & 50.00 & 49.97 & 49.90 & 49.94 & 49.92 \\
\hline Volume DIW added, ${ }^{d} \mathrm{~mL}$ & 48.55 & 48.65 & 48.58 & 48.51 & 48.62 & 48.60 & 48.66 & 48.57 & 48.62 & 48.60 & 48.53 & 48.51 \\
\hline Calculated volume CWF, mL & 1.39 & 1.27 & 1.41 & 1.47 & 1.38 & 1.37 & 1.32 & 1.43 & 1.35 & 1.30 & 1.41 & 1.41 \\
\hline $\begin{array}{l}\text { Calculated density CWF, } \\
\mathrm{g} / \mathrm{cm}^{3}\end{array}$ & 2.36 & 2.40 & 2.18 & 2.34 & 2.28 & 2.33 & 2.39 & 2.15 & 2.43 & 2.44 & 2.31 & 2.25 \\
\hline Specific surface area, $\mathrm{m}^{2} / \mathrm{g}$ & 0.0226 & 0.0222 & 0.0244 & 0.0227 & 0.0234 & 0.0229 & 0.0224 & 0.0249 & 0.0220 & 0.0219 & 0.0231 & 0.0237 \\
\hline
\end{tabular}

${ }^{\mathrm{a}}$ Volumetric flask \#1.

${ }^{\mathrm{b}}$ Volumetric flask \#2.

${ }^{\mathrm{c}}$ Volumetric flask \#3.

${ }^{\mathrm{d}}$ Calculated using density of demineralized water (DIW) at $40^{\circ} \mathrm{C}=0.99224 \mathrm{~g} / \mathrm{mL}$. 
Table 8. XRD patterns of sodalite, nepheline, and halite

\begin{tabular}{|c|c|c|c|c|c|c|c|c|c|c|c|}
\hline \multicolumn{2}{|c|}{ Sodalite } & \multicolumn{2}{|c|}{ Nepheline } & \multicolumn{2}{|c|}{ Halite } & \multicolumn{2}{|c|}{ Sodalite } & \multicolumn{2}{|c|}{ Nepheline } & \multicolumn{2}{|c|}{ Halite } \\
\hline$d(\AA \AA)$ & $\begin{array}{c}\text { I\% peak } \\
\text { height }\end{array}$ & $d(\AA)$ & $\begin{array}{c}1 \% \text { peak } \\
\text { height }\end{array}$ & $d(\AA)$ & $\begin{array}{c}1 \% \text { peak } \\
\text { height }\end{array}$ & $d(\AA)$ & $\begin{array}{c}\text { I\% peak } \\
\text { height }\end{array}$ & $d(\AA)$ & $\begin{array}{c}\text { I\% peak } \\
\text { height }\end{array}$ & $d(\AA)$ & $\begin{array}{c}\text { I\% peak } \\
\text { height }\end{array}$ \\
\hline \multirow[t]{2}{*}{6.28} & 40 & & & & & & & 1.8411 & 2 & & \\
\hline & & 5.0058 & 10 & & & 1.8122 & 2 & & & & \\
\hline \multirow[t]{3}{*}{4.44} & 5 & & & & & & & 1.7923 & 5 & & \\
\hline & & 4.3335 & 35 & & & 1.7413 & 2 & & & & \\
\hline & & 4.1766 & 80 & & & & & 1.6942 & 5 & & \\
\hline \multirow[t]{3}{*}{3.97} & 1 & & & & & & & 1.6346 & 6 & & \\
\hline & & 3.8438 & 100 & & & & & & & 1.628 & 15 \\
\hline & & 3.7614 & 2 & & & 1.621 & 2 & & & & \\
\hline \multirow[t]{7}{*}{3.624} & 100 & & & & & & & 1.615 & 8 & & \\
\hline & & 3.2731 & 70 & & & & & 1.6002 & 4 & & \\
\hline & & & & 3.26 & 13 & 1.5696 & 5 & & & & \\
\hline & & 3.0461 & 18 & & & & & 1.5614 & 14 & & \\
\hline & & 3.0059 & 100 & & & 1.5227 & 3 & & & & \\
\hline & & 2.8864 & 35 & & & 1.4797 & 4 & & & & \\
\hline & & & & 2.821 & 100 & & & & 5 & & \\
\hline 2.807 & 8 & & & & & & & 1.4555 & 3 & & \\
\hline \multirow[t]{2}{*}{2.563} & 16 & & & & & 1.4404 & 5 & & & & \\
\hline & & 2.5 & 14 & & & & & 1.4282 & 7 & & \\
\hline \multirow[t]{3}{*}{2.373} & 16 & & & & & & & & & 1.41 & 6 \\
\hline & & 2.3395 & 35 & & & 1.4038 & 1 & & & & \\
\hline & & 2.3074 & 25 & & & & & 1.3865 & 6 & & \\
\hline \multirow[t]{4}{*}{2.219} & 1 & & & & & 1.3699 & 2 & & & & \\
\hline & & 2.163 & 5 & & & 1.3385 & 2 & & & & \\
\hline & & 2.1188 & 7 & & & 1.3091 & 2 & & & & \\
\hline & & 2.0938 & 5 & & & 1.2814 & 2 & & & & \\
\hline \multirow[t]{2}{*}{2.093} & 20 & & & & & & & 1.279 & 6 & & \\
\hline & & & & 1.994 & 55 & 1.2684 & 1 & & & & \\
\hline \multirow[t]{2}{*}{1.985} & 3 & & & & & 1.2555 & 1 & & & & \\
\hline & & 1.9313 & 6 & & & & & 1.2347 & 4 & & \\
\hline 1.893 & 3 & & & & & 1.2081 & 3 & & & & \\
\hline
\end{tabular}

${ }^{\mathrm{a}}$ Sodalite from PDF No. 37-476; nepheline from PDF No. 15-424; halite from PDF No. 5-628. 
Table 9. Results of XRD analyses of salt-loaded CWF materials S1A, S2C, S4A, and S5B

\begin{tabular}{|c|c|c|c|c|c|c|c|c|c|c|c|c|c|}
\hline \multicolumn{3}{|c|}{ S1A } & \multicolumn{3}{|c|}{ S2C } & \multicolumn{3}{|c|}{ S4A } & \multicolumn{3}{|c|}{ S5B } & \multicolumn{2}{|c|}{ Reference phases $^{\mathrm{a}}$} \\
\hline$d(\AA)$ & $\begin{array}{c}1 \% \text { peak } \\
\text { area }\end{array}$ & $\begin{array}{c}1 \% \text { peak } \\
\text { height }\end{array}$ & $d(\AA)$ & $\begin{array}{c}\text { I\% peak } \\
\text { area }\end{array}$ & $\begin{array}{c}1 \% \text { peak } \\
\text { height }\end{array}$ & $d(\AA)$ & $\begin{array}{c}1 \% \text { peak } \\
\text { area }\end{array}$ & $\begin{array}{c}1 \% \text { peak } \\
\text { height }\end{array}$ & $d(\AA)$ & $\begin{array}{c}1 \% \text { peak } \\
\text { area }\end{array}$ & $\begin{array}{c}1 \% \text { peak } \\
\text { height }\end{array}$ & $\begin{array}{c}1 \% \text { peak } \\
\text { height }\end{array}$ & $d(\AA)$ \\
\hline & & & & & & & & & & & & 2.4 & 8.397 \\
\hline & & & & & & & & & 8.1124 & 0.3 & 2.4 & 2.4 & 8.06 \\
\hline & & & & & & & & & 7.8466 & 0.3 & 2.1 & 2.1 & 7.79 \\
\hline & & & & & & & & & 7.5985 & 0.2 & 2.0 & 2.0 & 7.55 \\
\hline & & & & & & & & & & & & 2.1 & 7.233 \\
\hline & & & & & & & & & & & & 1.9 & 6.920 \\
\hline 6.302 & 24.2 & 25.6 & 6.2935 & 27.4 & 24.2 & 6.3573 & 26.7 & 26.5 & 6.329 & 27.8 & 28.5 & $\mathrm{~S}(40)$ & 6.28 \\
\hline & & & & & & & & & & & & 2.2 & 5.277 \\
\hline & & & & & & & & & & & & 1.9 & 5.156 \\
\hline 5.0072 & 2.5 & 5.2 & 5.0073 & 0.4 & 2.7 & & & & 4.9973 & 0.2 & 2.5 & $\mathrm{~N}(10)$ & 5.0058 \\
\hline & & & & & & & & & 4.789 & 0.3 & 2.5 & 2.5 & 4.77 \\
\hline & & & & & & & & & & & & 2.9 & 4.763 \\
\hline & & & & & & & & & & & & 2.9 & 4.658 \\
\hline & & & & & & & & & 4.5541 & 0.9 & 3.2 & 3.2 & 4.54 \\
\hline 4.4491 & 5.2 & 9.1 & 4.4448 & 6.2 & 8.6 & 4.4722 & 7.6 & 9.3 & 4.4579 & 7.7 & 9.9 & $\mathrm{~S}(5)$ & 4.44 \\
\hline 4.3365 & 8.1 & 9.5 & 4.333 & 1.3 & 4.1 & & & & & & & $\mathrm{~N}(35)$ & 4.3335 \\
\hline 4.1838 & 12.4 & 17 & 4.1845 & 2.1 & 6.2 & 4.1631 & 1.2 & 3.1 & & & & $\mathrm{~N}(80)$ & 4.1766 \\
\hline & & & & & & & & & & & & 3.8 & 4.103 \\
\hline 3.9761 & 0.8 & 4.9 & 3.9763 & 0.8 & 4.5 & 3.9975 & 0.9 & 4.1 & 3.9804 & 0.9 & 4.4 & $\mathrm{~S}(1)$ & 3.97 \\
\hline 3.85 & 20.4 & 23.1 & 3.8474 & 5.3 & 8.1 & 3.8797 & 0.3 & 3.4 & & & & $N(100)$ & 3.8438 \\
\hline 3.7658 & 0.8 & 5.1 & & & & & & & 3.7866 & 0.3 & 4.0 & $\mathrm{~N}(2)$ & 3.7614 \\
\hline 3.6303 & 100 & 100 & 3.6274 & 100 & 100 & 3.6477 & 100 & 100 & 3.6335 & 100 & 100 & $S(100)$ & 3.624 \\
\hline & & & & & & & & & 3.5712 & 0.4 & 4.4 & 4.4 & 3.56 \\
\hline & & & & & & 3.4652 & 0.2 & 3.5 & & & & 3.5 & 3.44 \\
\hline & & & & & & 3.3778 & 0.2 & 3.5 & & & & 3.5 & 3.355 \\
\hline & & & & & & & & & & & & 3.3 & 3.343 \\
\hline 3.2757 & 16.6 & 17.6 & 3.2757 & 3.6 & 6.8 & 3.2873 & 0.7 & 3.8 & 3.2817 & 0.7 & 4.4 & $\mathrm{~N}(70)$ & 3.2731 \\
\hline & & & & & & & & & & & & $\mathrm{H}(13)$ & 3.26 \\
\hline & & & 3.1193 & 0.3 & 3.2 & 3.0951 & 0.2 & 3.1 & & & & 3.2 & 3.084 \\
\hline 3.0515 & 3.8 & 6.0 & 3.047 & 1.4 & 3.7 & & & & & & & $\mathrm{~N}(18)$ & 3.0461 \\
\hline 3.0093 & 23.9 & 23.8 & 3.0078 & 6.1 & 8.3 & 3.058 & 0.4 & 3.2 & 3.0735 & 0.3 & 3.6 & $\mathrm{~N}(100)$ & 3.0059 \\
\hline 2.8894 & 10.6 & 11.8 & 2.8897 & 2.3 & 4.8 & & & & & & & $\mathrm{~N}(35)$ & 2.8864 \\
\hline & & & & & & 2.8398 & 9.9 & 6.8 & 2.8395 & 11.7 & 8.2 & $\mathrm{H}(100)$ & 2.821 \\
\hline 2.8114 & 8.7 & 10.7 & 2.8084 & 8.7 & 10.8 & 2.8185 & 9.7 & 10.5 & 2.8115 & 10.0 & 10.4 & $\mathrm{~S}(8)$ & 2.807 \\
\hline & & & & & & & & & & & & 2.6 & 2.696 \\
\hline & & & & & & & & & & & & 2.5 & 2.665 \\
\hline
\end{tabular}


Table 9. (continued)

\begin{tabular}{|c|c|c|c|c|c|c|c|c|c|c|c|c|c|}
\hline \multicolumn{3}{|c|}{$\mathrm{S} 1 \mathrm{~A}$} & \multicolumn{3}{|c|}{$\mathrm{S} 2 \mathrm{C}$} & \multicolumn{3}{|c|}{ S4A } & \multicolumn{3}{|c|}{ S5B } & \multicolumn{2}{|c|}{ Reference phases } \\
\hline$d(\AA)$ & $\begin{array}{c}\text { I\% peak } \\
\text { area } \\
\end{array}$ & $\begin{array}{c}1 \% \text { peak } \\
\text { height }\end{array}$ & $d(\AA)$ & $\begin{array}{c}\text { I\% peak } \\
\text { area } \\
\end{array}$ & $\begin{array}{c}\text { I\% peak } \\
\text { height }\end{array}$ & $d(\AA)$ & $\begin{array}{c}1 \% \text { peak } \\
\text { area }\end{array}$ & $\begin{array}{c}1 \% \text { peak } \\
\text { height }\end{array}$ & $d(\AA)$ & $\begin{array}{c}1 \% \text { peak } \\
\text { area }\end{array}$ & $\begin{array}{c}1 \% \text { peak } \\
\text { height }\end{array}$ & $\begin{array}{c}\text { I\% peak } \\
\text { height }\end{array}$ & $d(\AA)$ \\
\hline \multirow[t]{2}{*}{2.5657} & 24.9 & 19.8 & 2.5643 & 20.8 & 21.2 & 2.5703 & 19.7 & 19.0 & 2.5644 & 20.4 & 20.0 & $\mathrm{~S}(16)$ & 2.563 \\
\hline & & & & & & & & & & & & 2.7 & 2.526 \\
\hline \multirow[t]{2}{*}{2.5008} & 3.2 & 4.7 & 2.5031 & 0.5 & 2.4 & & & & & & & $\mathrm{~N}(14)$ & 2.5 \\
\hline & & & & & & & & & & & & 2.2 & 2.45 \\
\hline 2.4012 & 2.8 & 4.5 & & & & & & & & & & $\mathrm{~N}(10)$ & 2.4007 \\
\hline 2.3754 & 21.0 & 20.1 & 2.3732 & 20.4 & 19.9 & 2.3792 & 20.7 & 19.7 & 2.3732 & 20.5 & 19.3 & $\mathrm{~S}(16)$ & 2.373 \\
\hline 2.3424 & 9.8 & 11.6 & 2.3435 & 0.8 & 3.9 & & & & & & & $\mathrm{~N}(35)$ & 2.3395 \\
\hline 2.3086 & 6.3 & 7.4 & 2.3077 & 1.3 & 3.1 & & & & & & & $\mathrm{~N}(25)$ & 2.3074 \\
\hline \multirow[t]{2}{*}{2.2193} & 1.4 & 3.3 & 2.2184 & 1.2 & 2.8 & 2.2235 & 1.5 & 2.4 & 2.2201 & 1.1 & 2.7 & $\mathrm{~S}(1)$ & 2.219 \\
\hline & & & & & & & & & & & & 2.1 & 2.203 \\
\hline 2.1622 & 0.8 & 2.8 & & & & & & & 2.1759 & 0.1 & 1.9 & $\mathrm{~N}(5)$ & 2.163 \\
\hline \multirow[t]{2}{*}{2.1214} & 1.9 & 3.9 & 2.1169 & 0.6 & 2.2 & & & & & & & $\mathrm{~N}(7)$ & 2.1188 \\
\hline & & & & & & & & & & & & $\mathrm{N}(5)$ & 2.0938 \\
\hline \multirow[t]{3}{*}{2.0934} & 39.8 & 29.7 & 2.0925 & 34.6 & 29.7 & 2.097 & 32.4 & 27.9 & 2.0924 & 29.9 & 24 & $S(20)$ & 2.093 \\
\hline & & & & & & & & & & & & 2.3 & 2.073 \\
\hline & & & & & & 2.0044 & 3.2 & 3 & 2.0042 & 5.4 & 4.4 & $\mathrm{H}(55)$ & 1.994 \\
\hline 1.9854 & 6.6 & 6.6 & 1.986 & 5.5 & 5.8 & 1.9879 & 5.4 & 5.2 & 1.9829 & 5.2 & 5.3 & $\mathrm{~S}(3)$ & 1.985 \\
\hline 1.9325 & 3.8 & 4.0 & 1.9347 & 0.8 & 2.0 & & & & 1.9162 & 0.1 & 1.6 & $\mathrm{~N}(6)$ & 1.9313 \\
\hline 1.8938 & 5.5 & 5.9 & 1.8923 & 4.1 & 5.0 & 1.8961 & 4.1 & 5.0 & 1.8915 & 4.5 & 4.6 & $S(3)$ & 1.893 \\
\hline 1.842 & 0.8 & 2.2 & 1.8414 & 0.2 & 1.6 & & & & 1.8489 & 0.4 & 1.5 & $\mathrm{~N}(2)$ & 1.8411 \\
\hline 1.8125 & 3.7 & 4.5 & 1.8130 & 4.2 & 4.5 & 1.8157 & 3.4 & 4.0 & 1.8104 & 4.1 & 4.4 & $\mathrm{~S}(2)$ & 1.8122 \\
\hline 1.7937 & 1.9 & 2.7 & & & & & & & & & & $\mathrm{~N}(5)$ & 1.7923 \\
\hline \multirow[t]{2}{*}{1.741} & 3.2 & 4.0 & 1.741 & 3.6 & 4.2 & 1.7433 & 3.8 & 4.1 & 1.7385 & 4.3 & 4.2 & $\mathrm{~S}(2)$ & 1.7413 \\
\hline & & & & & & & & & & & & 1.4 & 1.720 \\
\hline 1.6932 & 1.4 & 2.7 & & & & & & & & & & $\mathrm{~N}(5)$ & 1.6942 \\
\hline \multirow[t]{3}{*}{1.6354} & 0.7 & 2.5 & & & & 1.6348 & 1.0 & 1.8 & 1.6342 & 1.3 & 2.2 & $\mathrm{~N}(6)$ & 1.6346 \\
\hline & & & & & & & & & & & & $\mathrm{H}(15)$ & 1.628 \\
\hline & & & 1.6206 & 4.0 & 4.2 & 1.6222 & 3.7 & 3.4 & & & & $\mathrm{~S}(2)$ & 1.621 \\
\hline 1.6175 & 6.5 & 4.6 & & & & & & & 1.6185 & 2.3 & 3.5 & $\mathrm{~N}(8)$ & 1.615 \\
\hline 1.5999 & 1.3 & 2.5 & & & & & & & & & & $\mathrm{~N}(4)$ & 1.6002 \\
\hline 1.57 & 14.2 & 9.6 & 1.5691 & 13.7 & 10.3 & 1.5705 & 12.5 & 9.8 & 1.5676 & 12.7 & 9.4 & $S(5)$ & 1.5696 \\
\hline \multirow[t]{2}{*}{1.5595} & 7.3 & 5.5 & & & & & & & & & & $\mathrm{~N}(14)$ & 1.5614 \\
\hline & & & & & & & & & & & & 1.8 & 1.531 \\
\hline 1.5231 & 7.4 & 6.2 & 1.5230 & 7.2 & 5.5 & 1.5231 & 6.2 & 5.5 & 1.5199 & 6.1 & 5.3 & $\mathrm{~S}(3)$ & 1.5227 \\
\hline
\end{tabular}


Table 9. (continued)

\begin{tabular}{|c|c|c|c|c|c|c|c|c|c|c|c|c|c|}
\hline \multicolumn{3}{|c|}{$\mathrm{S} 1 \mathrm{~A}$} & \multicolumn{3}{|c|}{ S2C } & \multicolumn{3}{|c|}{ S4A } & \multicolumn{3}{|c|}{ S5B } & \multicolumn{2}{|c|}{ Reference phases } \\
\hline$d(\AA)$ & $\begin{array}{c}\text { I\% peak } \\
\text { area } \\
\end{array}$ & $\begin{array}{c}\text { I\% peak } \\
\text { height }\end{array}$ & $d(\AA)$ & $\begin{array}{c}\text { I\% peak } \\
\text { area } \\
\end{array}$ & $\begin{array}{c}\text { I\% peak } \\
\text { height }\end{array}$ & $d(\AA)$ & $\begin{array}{c}1 \% \text { peak } \\
\text { area }\end{array}$ & $\begin{array}{c}1 \% \text { peak } \\
\text { height }\end{array}$ & $d(\AA)$ & $\begin{array}{c}1 \% \text { peak } \\
\text { area }\end{array}$ & $\begin{array}{c}1 \% \text { peak } \\
\text { height }\end{array}$ & $\begin{array}{c}\text { I\% peak } \\
\text { height }\end{array}$ & $d(\AA)$ \\
\hline 1.4801 & 10.2 & 8.4 & 1.4793 & 10.4 & 8.9 & 1.4798 & 9.2 & 7.6 & 1.4779 & 9.5 & 6.6 & $S(4)$ & 1.4797 \\
\hline 1.4705 & 1.9 & 2.8 & & & & & & & & & & $\mathrm{~N}(5)$ & 1.4687 \\
\hline 1.456 & 0.5 & 2.2 & 1.4591 & 0.2 & 1.6 & & & & & & & $\mathrm{~N}(3)$ & 1.4555 \\
\hline 1.4407 & 10.5 & 8.3 & 1.4399 & 11.8 & 9.3 & 1.4404 & 10.5 & 8.1 & 1.4376 & 10.3 & 7.5 & $\mathrm{~S}(5)$ & 1.4404 \\
\hline 1.4297 & 3.6 & 3.3 & & & & & & & & & & $\mathrm{~N}(7)$ & 1.4282 \\
\hline & & & & & & & & & 1.4139 & 0.3 & 1.5 & $\mathrm{H}(6)$ & 1.41 \\
\hline 1.4037 & 0.4 & 2.1 & 1.4034 & 0.4 & 1.8 & & & & 1.4012 & 0.9 & 1.8 & $S(1)$ & 1.4038 \\
\hline 1.3861 & 5.6 & 4.0 & 1.3857 & 0.8 & 1.8 & & & & & & & $\mathrm{~N}(6)$ & 1.3865 \\
\hline 1.3704 & 5.3 & 4.7 & 1.3694 & 4.3 & 4.1 & 1.3700 & 4.9 & 3.9 & 1.3669 & 3.9 & 3.8 & $\mathrm{~S}(2)$ & 1.3699 \\
\hline 1.3389 & 4.2 & 3.8 & 1.338 & 3.8 & 4.1 & 1.338 & 5.2 & 4.0 & 1.3642 & 2.1 & 2.9 & $\mathrm{~S}(2)$ & 1.3385 \\
\hline & & & & & & 1.335 & 1.4 & 2.5 & 1.3356 & 4.4 & 3.8 & $2.5,3.8$ & 1.333 \\
\hline 1.3092 & 7.2 & 4.0 & 1.3089 & 4.5 & 4.1 & 1.3083 & 4.3 & 3.6 & 1.3058 & 4.2 & 3.4 & $\mathrm{~S}(2)$ & 1.3091 \\
\hline & & & & & & & & & 1.303 & 2.4 & 2.8 & 2.8 & 1.308 \\
\hline 1.2809 & 4.3 & 3.4 & 1.2811 & 3.4 & 3.4 & 1.2811 & 2.3 & 2.8 & 1.2785 & 2.5 & 2.8 & $\mathrm{~S}(2)$ & 1.2814 \\
\hline 1.2787 & 6.0 & 3.5 & & & & & & & & & & $\mathrm{~N}(6)$ & 1.279 \\
\hline 1.2676 & 0.6 & 2.1 & & & & & & & 1.2641 & 1.0 & 1.9 & $S(1)$ & 1.2684 \\
\hline 1.2545 & 0.6 & 2.1 & & & & & & & & & & $\mathrm{~S}(1)$ & 1.2555 \\
\hline 1.2363 & 1.0 & 1.8 & 1.2304 & 0.6 & 1.6 & 1.2301 & 0.7 & 1.5 & 1.2287 & 0.4 & 1.5 & $\mathrm{~N}(4)$ & 1.2347 \\
\hline 1.2082 & 10.5 & 6.8 & 1.2077 & 10.0 & 7.1 & 1.2072 & 7.1 & 6.1 & 1.2054 & 7.8 & 5.3 & $\mathrm{~S}(3)$ & 1.2081 \\
\hline
\end{tabular}

${ }^{\mathrm{a}} \mathrm{S}$ = sodalite, $\mathrm{N}=$ nepheline, $\mathrm{H}=$ halite; the relative heights for reference patterns are given in parentheses. 
Table 10. Results of XRD analyses of salt-loaded CWF materials S3A, S3B, S3C, and S3E

\begin{tabular}{|c|c|c|c|c|c|c|c|c|c|c|c|c|c|}
\hline \multicolumn{3}{|c|}{ S3A } & \multicolumn{3}{|c|}{ S3B } & \multicolumn{3}{|c|}{ S3C } & \multicolumn{3}{|c|}{ S3E } & \multicolumn{2}{|c|}{ Reference phases } \\
\hline$d(\AA)$ & $\begin{array}{c}1 \% \text { peak } \\
\text { area } \\
\end{array}$ & $\begin{array}{c}\text { I\% peak } \\
\text { height }\end{array}$ & $d(\AA)$ & $\begin{array}{c}\text { I\% peak } \\
\text { area } \\
\end{array}$ & $\begin{array}{c}\text { I\% peak } \\
\text { height }\end{array}$ & $d(\AA)$ & $\begin{array}{c}1 \% \text { peak } \\
\text { area }\end{array}$ & $\begin{array}{c}1 \% \text { peak } \\
\text { height }\end{array}$ & $d(\AA)$ & $\begin{array}{c}\text { I\% peak } \\
\text { area } \\
\end{array}$ & $\begin{array}{c}1 \% \text { peak } \\
\text { height }\end{array}$ & $\begin{array}{c}1 \% \text { peak } \\
\text { height }\end{array}$ & $d(\AA)$ \\
\hline & & & & & & & & & & & & 2.4 & 8.397 \\
\hline & & & & & & & & & & & & 2.4 & 8.112 \\
\hline & & & & & & & & & & & & 2.1 & 7.847 \\
\hline & & & & & & & & & & & & 2.0 & 7.599 \\
\hline & & & & & & & & & & & & 2.1 & 7.233 \\
\hline 6.9204 & 0.1 & 1.7 & & & & & & & & & & 1.9 & 6.920 \\
\hline 6.3112 & 24.5 & 25.4 & 6.3567 & 26.1 & 24.0 & 6.3024 & 24.9 & 25.9 & 6.3581 & 26.7 & 25.9 & $\mathrm{~S}(40)$ & 6.28 \\
\hline & & & & & & & & & 5.277 & 0.2 & 2.2 & 2.2 & 5.277 \\
\hline & & & & & & & & & & & & 1.9 & 5.156 \\
\hline & & & & & & & & & 5.0209 & 0.3 & 2.1 & $\mathrm{~N}(10)$ & 5.0058 \\
\hline & & & & & & & & & & & & 2.5 & 4.789 \\
\hline & & & & & & & & & & & & 2.9 & 4.763 \\
\hline & & & & & & & & & & & & 2.9 & 4.658 \\
\hline & & & & & & & & & & & & 3.2 & 4.554 \\
\hline 4.4493 & 6.1 & 8.8 & 4.4759 & 8.0 & 7.1 & 4.4489 & 6.6 & 8.6 & 4.4761 & 7.6 & 9.9 & $\mathrm{~S}(5)$ & 4.44 \\
\hline & & & & & & & & & & & & $\mathrm{N}(35)$ & 4.3335 \\
\hline & & & 4.2221 & 0.5 & 0.5 & & & & 4.2262 & 0.2 & 3.0 & & 4.191 \\
\hline & & & & & & & & & & & & $\mathrm{N}(80)$ & 4.1766 \\
\hline & & & & & & & & & & & & 3.8 & 4.103 \\
\hline 3.9794 & 0.7 & 4.1 & 3.9977 & 1.3 & 1.0 & 3.9759 & 0.9 & 3.7 & 3.9985 & 1.1 & 4.0 & $S(1)$ & 3.97 \\
\hline 3.8537 & 0.7 & 3.7 & 3.8768 & 1.2 & 0.9 & 3.8503 & 0.7 & 3.6 & 3.8706 & 0.2 & 3.5 & $\mathrm{~N}(100)$ & 3.8438 \\
\hline & & & & & & & & & & & & $\mathrm{N}(2)$ & 3.7614 \\
\hline 3.6304 & 100 & 100 & 3.648 & 100 & 100 & 3.6275 & 100 & 100 & 3.6481 & 100 & 100 & $S(100)$ & 3.624 \\
\hline & & & 3.6098 & 1.1 & 0.9 & & & & & & & 4.4 & 3.571 \\
\hline & & & & & & & & & & & & 3.5 & 3.466 \\
\hline & & & & & & & & & & & & 3.5 & 3.378 \\
\hline & & & & & & & & & 3.3428 & 0.7 & 3.3 & 3.3 & 3.323 \\
\hline 3.2732 & 1.0 & 3.9 & 3.2946 & 1.7 & 0.8 & 3.2716 & 0.7 & 3.5 & 3.2876 & 0.6 & 3.6 & $\mathrm{~N}(70)$ & 3.2731 \\
\hline & & & & & & 3.2317 & 0.3 & 3.1 & & & & $\mathrm{H}(13)$ & 3.26 \\
\hline 3.0576 & 0.4 & 3.2 & 3.1204 & 0.4 & 0.3 & 3.1576 & 0.3 & 2.9 & & & & $3.2,2.9$ & 3.149 \\
\hline & & & & & & & & & & & & $\mathrm{N}(18)$ & 3.0461 \\
\hline 3.0142 & 0.5 & 3.3 & 3.0254 & 1.5 & 0.9 & 3.0129 & 0.5 & 3.0 & 3.0261 & 0.5 & 3.0 & $\mathrm{~N}(100)$ & 3.0059 \\
\hline 2.892 & 0.2 & 2.7 & 2.9006 & 0.7 & 0.5 & 2.88 & 0.2 & 2.5 & & & & $\mathrm{~N}(35)$ & 2.8864 \\
\hline 2.829 & 9.5 & 5.3 & 2.8378 & 12.7 & 4.7 & 2.8321 & 8.7 & 5 & 2.8414 & 9.2 & 4.3 & $\mathrm{H}(100)$ & 2.821 \\
\hline 2.8083 & 10.6 & 10.5 & 2.8203 & 11.5 & 8.8 & 2.8082 & 9.9 & 10.8 & 2.8203 & 11.1 & 11.2 & $S(8)$ & 2.807 \\
\hline & & & & & & & & & & & & 2.6 & 2.696 \\
\hline & & & & & & & & & & & & 2.5 & 2.665 \\
\hline
\end{tabular}


Table 10. (continued)

\begin{tabular}{|c|c|c|c|c|c|c|c|c|c|c|c|c|c|}
\hline \multicolumn{3}{|c|}{ S3A } & \multicolumn{3}{|c|}{ S3B } & \multicolumn{3}{|c|}{ S3C } & \multicolumn{3}{|c|}{ S3E } & \multicolumn{2}{|c|}{ Reference phases } \\
\hline$d(\AA)$ & $\begin{array}{c}1 \% \text { peak } \\
\text { area }\end{array}$ & $\begin{array}{c}\text { I\% peak } \\
\text { height }\end{array}$ & $d(\AA)$ & $\begin{array}{c}\text { I\% peak } \\
\text { area }\end{array}$ & $\begin{array}{c}\text { I\% peak } \\
\text { height }\end{array}$ & $d(\AA)$ & $\begin{array}{c}1 \% \text { peak } \\
\text { area }\end{array}$ & $\begin{array}{c}\text { I\% peak } \\
\text { height }\end{array}$ & $d(\AA)$ & $\begin{array}{c}1 \% \text { peak } \\
\text { area }\end{array}$ & $\begin{array}{c}\text { I\% peak } \\
\text { height }\end{array}$ & $\begin{array}{c}\text { I\% peak } \\
\text { height }\end{array}$ & $d(\AA)$ \\
\hline \multirow[t]{5}{*}{2.5631} & 20.0 & 20.8 & 2.5729 & 20.7 & 20.2 & 2.563 & 19.6 & 21.2 & 2.573 & 19.9 & 19.9 & $S(16)$ & 2.563 \\
\hline & & & & & & & & & & & & 2.7 & 2.526 \\
\hline & & & & & & & & & & & & $\mathrm{N}(14)$ & 2.5 \\
\hline & & & & & & & & & & & & 2.2 & 2.45 \\
\hline & & & & & & & & & & & & $\mathrm{N}(10)$ & 2.4007 \\
\hline \multirow[t]{4}{*}{2.3742} & 21.6 & 19.8 & 2.3805 & 21.1 & 20.7 & 2.372 & 21.6 & 20.5 & 2.3805 & 21.1 & 20.5 & $S(16)$ & 2.373 \\
\hline & & & 2.3552 & 0.9 & 0.7 & & & & & & & & 2.348 \\
\hline & & & & & & & & & & & & $\mathrm{N}(35)$ & 2.3395 \\
\hline & & & & & & & & & & & & $\mathrm{N}(25)$ & 2.3074 \\
\hline \multirow[t]{5}{*}{2.2202} & 1.3 & 2.8 & 2.2265 & 1.6 & 1.4 & 2.2182 & 1.2 & 2.7 & 2.2257 & 1.6 & 2.5 & $S(1)$ & 2.219 \\
\hline & & & & & & & & & & & & 2.1 & 2.203 \\
\hline & & & & & & 2.1611 & 0.2 & 1.7 & 2.19 & 0.2 & 1.6 & $\mathrm{~N}(5)$ & 2.163 \\
\hline & & & & & & & & & & & & $\mathrm{N}(7)$ & 2.1188 \\
\hline & & & & & & & & & & & & $N(5)$ & 2.0938 \\
\hline \multirow[t]{2}{*}{2.0924} & 32.4 & 28.7 & 2.098 & 32.4 & 31.1 & 2.0915 & 32.8 & 30.8 & 2.098 & 32.3 & 27.9 & $S(20)$ & 2.093 \\
\hline & & & & & & & & & & & & 2.3 & 2.073 \\
\hline 1.9986 & 2.2 & 2.8 & 2.0036 & 2.9 & 2.0 & 1.9992 & 2.8 & 2.6 & 2.006 & 2.1 & 2.5 & $\mathrm{H}(55)$ & 1.994 \\
\hline \multirow[t]{2}{*}{1.9853} & 6.3 & 5.7 & 1.9902 & 5.2 & 4.9 & 1.9844 & 5.2 & 5.8 & 1.9895 & 5.1 & 5.7 & $S(3)$ & 1.985 \\
\hline & & & & & & & & & & & & $N(6)$ & 1.9313 \\
\hline \multirow[t]{2}{*}{1.8916} & 4.3 & 4.7 & 1.8968 & 4.7 & 4.1 & 1.8916 & 4.2 & 4.9 & 1.8968 & 4.2 & 4.6 & $S(3)$ & 1.893 \\
\hline & & & & & & & & & & & & $N(2)$ & 1.8411 \\
\hline \multirow[t]{2}{*}{1.8112} & 3.8 & 4.2 & 1.8158 & 4.2 & 3.8 & 1.8117 & 3.8 & 4.3 & 1.8152 & 3.6 & 3.8 & $\mathrm{~S}(2)$ & 1.8122 \\
\hline & & & & & & & & & & & & $\mathrm{N}(5)$ & 1.7923 \\
\hline \multirow[t]{5}{*}{1.7409} & 3.9 & 4.1 & 1.744 & 3.9 & 3.8 & 1.7397 & 4.0 & 4.3 & 1.7435 & 3.8 & 3.7 & $\mathrm{~S}(2)$ & 1.7413 \\
\hline & & & & & & & & & 1.7204 & 0.1 & 1.4 & 1.4 & 1.720 \\
\hline & & & & & & & & & 1.7028 & 0.3 & 1.3 & $\mathrm{~N}(5)$ & 1.6942 \\
\hline & & & 1.6338 & 1.1 & 0.6 & & & & 1.6343 & 0.4 & 1.6 & $\mathrm{~N}(6)$ & 1.6346 \\
\hline & & & & & & & & & & & & $\mathrm{H}(15)$ & 1.628 \\
\hline \multirow[t]{3}{*}{1.6200} & 3.7 & 3.7 & 1.6227 & 3.5 & 3.0 & 1.6195 & 3.2 & 3.6 & 1.6232 & 3.3 & 3.3 & $S(2)$ & 1.621 \\
\hline & & & & & & & & & & & & $\mathrm{N}(8)$ & 1.615 \\
\hline & & & & & & & & & & & & $\mathrm{N}(4)$ & 1.6002 \\
\hline \multirow[t]{3}{*}{1.5686} & 13.0 & 10.5 & 1.5711 & 12.8 & 11.0 & 1.5681 & 16.3 & 10.1 & 1.5711 & 12.3 & 10.3 & $S(5)$ & 1.5696 \\
\hline & & & & & & & & & & & & $\mathrm{N}(14)$ & 1.5614 \\
\hline & & & & & & & & & & & & 1.8 & 1.531 \\
\hline 1.5217 & 6.1 & 5.7 & 1.524 & 6.5 & 5.4 & 1.5213 & 7 & 5.7 & 1.5244 & 6.0 & 5.4 & $S(3)$ & 1.5227 \\
\hline
\end{tabular}


Table 10. (continued)

\begin{tabular}{|c|c|c|c|c|c|c|c|c|c|c|c|c|c|}
\hline \multicolumn{3}{|c|}{ S3A } & \multicolumn{3}{|c|}{ S3B } & \multicolumn{3}{|c|}{ S3C } & \multicolumn{3}{|c|}{ S3E } & \multicolumn{2}{|c|}{ Reference phases } \\
\hline$d(\AA)$ & $1 \%$ area & $\begin{array}{c}1 \% \text { peak } \\
\text { height }\end{array}$ & $d(\AA)$ & $1 \%$ area & $\begin{array}{c}\text { I\% peak } \\
\text { height }\end{array}$ & $d(\AA)$ & $1 \%$ area & $\begin{array}{c}\text { I\% peak } \\
\text { height }\end{array}$ & $d(\AA)$ & $\begin{array}{c}1 \% \text { peak } \\
\text { area }\end{array}$ & $\begin{array}{c}\text { I\% peak } \\
\text { height }\end{array}$ & $\begin{array}{c}\text { I\% peak } \\
\text { height }\end{array}$ & $d(\AA)$ \\
\hline \multirow[t]{3}{*}{1.4785} & 10.1 & 8.7 & 1.481 & 10.1 & 8.7 & 1.478 & 8.4 & 8.6 & 1.481 & 10.6 & 8.0 & $S(4)$ & 1.4797 \\
\hline & & & & & & & & & & & & $\mathrm{N}(5)$ & 1.4687 \\
\hline & & & & & & & & & & & & $\mathrm{N}(3)$ & 1.4555 \\
\hline \multirow[t]{3}{*}{1.4388} & 12.6 & 8.5 & 1.4411 & 11.0 & 9.0 & 1.4384 & 11.0 & 8.7 & 1.4415 & 11.3 & 8.4 & $S(5)$ & 1.4404 \\
\hline & & & & & & & & & & & & $\mathrm{N}(7)$ & 1.4282 \\
\hline & & & & & & & & & & & & $\mathrm{H}(6)$ & 1.41 \\
\hline 1.4032 & 0.4 & 1.6 & 1.4049 & 0.8 & 0.5 & 1.4033 & 0.5 & 1.6 & 1.4048 & 0.9 & 1.8 & $S(1)$ & 1.4038 \\
\hline \multirow[t]{2}{*}{1.3683} & 4.0 & 3.9 & 1.3707 & 4.3 & 3.5 & 1.368 & 4.4 & 4.1 & 1.3704 & 4.3 & 3.9 & $\mathrm{~N}(6)$ & 1.3865 \\
\hline & & & & & & & & & & & & $S(2)$ & 1.3699 \\
\hline \multirow[t]{2}{*}{1.337} & 4.6 & 4.1 & 1.339 & 4.3 & 3.4 & 1.3369 & 4.9 & 3.8 & 1.3392 & 4.6 & 3.9 & $\mathrm{~S}(2)$ & 1.3385 \\
\hline & & & & & & & & & & & & $2.5,3.8$ & 1.336 \\
\hline \multirow[t]{2}{*}{1.3082} & 3.4 & 3.7 & 1.3095 & 4.5 & 3.3 & 1.3076 & 4.6 & 3.8 & 1.3095 & 4.0 & 4.0 & $\mathrm{~S}(2)$ & 1.3091 \\
\hline & & & & & & & & & & & & 2.5 & 1.305 \\
\hline \multirow[t]{4}{*}{1.28} & 2.8 & 3.2 & 1.2817 & 3.7 & 2.6 & 1.2799 & 2.5 & 3.1 & 1.2817 & 2.7 & 2.6 & $\mathrm{~S}(2)$ & 1.2814 \\
\hline & & & & & & & & & & & & $\mathrm{N}(6)$ & 1.279 \\
\hline & & & 1.2647 & 1.2 & 0.4 & 1.2632 & 0.2 & 1.2 & & & & $S(1)$ & 1.2684 \\
\hline & & & & & & & & & & & & $S(1)$ & 1.2555 \\
\hline 1.2301 & 1.2 & 1.4 & 1.2314 & 1.1 & 0.7 & 1.2298 & 0.6 & 1.4 & 1.2312 & 0.6 & 1.4 & $\mathrm{~N}(4)$ & 1.2347 \\
\hline 1.2069 & 8.8 & 6.4 & 1.2082 & 10.3 & 7.1 & 1.2066 & 8.3 & 6.1 & 1.2079 & 9.1 & 6.3 & $S(3)$ & 1.2081 \\
\hline
\end{tabular}

${ }^{\mathrm{a}} \mathrm{S}=$ sodalite, $\mathrm{N}=$ nepheline, $\mathrm{H}=$ halite; the relative heights for reference patterns are given in parentheses. 
Table 11. Results of XRD analyses of salt-loaded CWF materials G1A, G2A, G4A, and G5A

\begin{tabular}{|c|c|c|c|c|c|c|c|c|c|c|c|c|c|}
\hline \multicolumn{3}{|c|}{ G1A } & \multicolumn{3}{|c|}{ G2A } & \multicolumn{3}{|c|}{ G4A } & \multicolumn{3}{|c|}{ G5A } & \multicolumn{2}{|c|}{ Reference phases ${ }^{2}$} \\
\hline$d(\AA \AA)$ & $\begin{array}{c}1 \% \text { peak } \\
\text { area }\end{array}$ & $\begin{array}{c}\text { I\% peak } \\
\text { height }\end{array}$ & $d(\AA)$ & $\begin{array}{c}1 \% \text { peak } \\
\text { area }\end{array}$ & $\begin{array}{c}\text { I\% peak } \\
\text { height }\end{array}$ & $d(\AA \AA)$ & $\begin{array}{c}\text { I\% peak } \\
\text { area }\end{array}$ & $\begin{array}{c}\text { I\% peak } \\
\text { height }\end{array}$ & $d(\AA)$ & $\begin{array}{c}\text { I\% peak } \\
\text { area }\end{array}$ & $\begin{array}{c}\text { I\% peak } \\
\text { height }\end{array}$ & $\begin{array}{c}1 \% \text { peak } \\
\text { height }\end{array}$ & $d(\AA)$ \\
\hline & & & 8.3972 & 0.2 & 2.4 & & & & & & & 2.4 & 8.397 \\
\hline & & & & & & & & & & & & 2.4 & 8.112 \\
\hline & & & & & & & & & & & & 2.1 & 7.847 \\
\hline & & & & & & & & & & & & 2 & 7.599 \\
\hline & & & & & & & & & 7.2325 & 0.2 & 2.1 & 2.1 & 7.19 \\
\hline 6.9469 & 0.2 & 1.9 & & & & & & & & & & 1.9 & 6.920 \\
\hline 6.3476 & 29.3 & 31.5 & 6.3651 & 26.5 & 27.5 & 6.3393 & 26.4 & 27.0 & 6.3211 & 24.1 & 25.5 & $\mathrm{~S}(40)$ & 6.28 \\
\hline & & & & & & & & & & & & 2.2 & 5.277 \\
\hline 5.1556 & 0.4 & 1.9 & & & & & & & & & & 1.9 & 5.156 \\
\hline & & & & & & & & & & & & $\mathrm{N}(10)$ & 5.0058 \\
\hline & & & & & & & & & & & & 2.5 & 4.789 \\
\hline & & & & & & & & & 4.7632 & 0.5 & 2.9 & 2.9 & 4.75 \\
\hline & & & & & & & & & 4.6578 & 0.5 & 2.9 & 2.9 & 4.64 \\
\hline & & & & & & & & & & & & 3.2 & 4.554 \\
\hline 4.4669 & 8.2 & 9.7 & 4.4717 & 7.3 & 8.9 & 4.4674 & 6.0 & 9.6 & 4.4582 & 7.4 & 9.0 & $S(5)$ & 4.44 \\
\hline & & & 4.2538 & 0.2 & 2.8 & & & & 4.3236 & 0.5 & 3.5 & $\mathrm{~N}(35)$ & 4.3335 \\
\hline & & & & & & & & & 4.204 & 0.2 & 3.8 & $\mathrm{~N}(80)$ & 4.1766 \\
\hline & & & & & & & & & 4.1028 & 1.3 & 3.8 & 3.8 & 4.092 \\
\hline 3.9929 & 1.0 & 3.6 & 4.0027 & 0.9 & 4.1 & 3.9968 & 0.8 & 4.1 & 3.9813 & 1.0 & 4.8 & $\mathrm{~S}(1)$ & 3.97 \\
\hline & & & 3.8743 & 0.1 & 3.3 & 3.869 & 0.9 & 3.8 & & & & $\mathrm{~N}(100)$ & 3.8438 \\
\hline & & & & & & & & & 3.7951 & 0.3 & 4.2 & $\mathrm{~N}(2)$ & 3.7614 \\
\hline 3.6392 & 100 & 100 & 3.6451 & 100 & 100 & 3.6422 & 100 & 100 & 3.6362 & 100 & 100 & $S(100)$ & 3.624 \\
\hline & & & & & & & & & & & & 4.4 & 3.571 \\
\hline & & & & & & & & & 3.4663 & 0.3 & 4.4 & 3.5 & 3.454 \\
\hline & & & & & & & & & & & & 3.5 & 3.378 \\
\hline & & & & & & & & & & & & 3.3 & 3.343 \\
\hline 3.2913 & 0.6 & 3.4 & 3.2864 & 0.7 & 3.7 & 3.2895 & 1.6 & 4.0 & 3.2714 & 0.9 & 4.7 & $\mathrm{~N}(70)$ & 3.2731 \\
\hline & & & & & & & & & 3.2349 & 0.2 & 3.9 & $\mathrm{H}(13)$ & 3.26 \\
\hline 3.1624 & 0.2 & 3.0 & & & & 3.1553 & 0.2 & 3.4 & 3.1493 & 0.3 & 3.9 & $3,3.4,3.9$ & 3.136 \\
\hline & & & & & & & & & 3.0679 & 0.9 & 3.6 & $\mathrm{~N}(18)$ & 3.0461 \\
\hline 3.0489 & 0.2 & 2.9 & 3.0909 & 0.2 & 3.1 & 3.0199 & 0.3 & 3.5 & 3.0184 & 0.4 & 3.8 & $\mathrm{~N}(100)$ & 3.0059 \\
\hline & & & & & & 2.891 & 0.2 & 2.9 & 2.8642 & 1.3 & 3.3 & $\mathrm{~N}(35)$ & 2.8864 \\
\hline 2.8431 & 7.2 & 6.5 & 2.8446 & 7.4 & 6.7 & 2.8377 & 9.9 & 5.4 & 2.8326 & 6.8 & 6.9 & $\mathrm{H}(100)$ & 2.821 \\
\hline 2.8118 & 9.4 & 10.3 & 2.8169 & 9.9 & 10.5 & 2.8169 & 10.5 & 10.8 & 2.8132 & 12.5 & 10.7 & $\mathrm{~S}(8)$ & 2.807 \\
\hline & & & & & & & & & 2.6964 & 0.3 & 2.6 & 2.6 & 2.690 \\
\hline & & & & & & & & & 2.6647 & 0.4 & 2.5 & 2.5 & 2.660 \\
\hline
\end{tabular}


Table 11. (continued)

\begin{tabular}{|c|c|c|c|c|c|c|c|c|c|c|c|c|c|}
\hline \multicolumn{3}{|c|}{ G1A } & \multicolumn{3}{|c|}{ G2A } & \multicolumn{3}{|c|}{ G4A } & \multicolumn{3}{|c|}{ G5A } & \multicolumn{2}{|c|}{ Reference phases } \\
\hline$d(\AA)$ & $\begin{array}{c}1 \% \text { peak } \\
\text { area }\end{array}$ & $\begin{array}{c}\text { I\% peak } \\
\text { height }\end{array}$ & $d(\AA)$ & $\begin{array}{c}1 \% \text { peak } \\
\text { area }\end{array}$ & $\begin{array}{c}1 \% \text { peak } \\
\text { height }\end{array}$ & $d(\AA)$ & $\begin{array}{c}1 \% \text { peak } \\
\text { area }\end{array}$ & $\begin{array}{c}1 \% \text { peak } \\
\text { height }\end{array}$ & $d(\AA)$ & $\begin{array}{c}1 \% \text { peak } \\
\text { area }\end{array}$ & $\begin{array}{c}1 \% \text { peak } \\
\text { height }\end{array}$ & $\begin{array}{c}1 \% \text { peak } \\
\text { height }\end{array}$ & $d(\AA)$ \\
\hline \multirow[t]{5}{*}{2.5671} & 21.7 & 19.8 & 2.57 & 21.2 & 20.3 & 2.5702 & 19.8 & 20.2 & 2.5673 & 19.7 & 20.1 & $S(16)$ & 2.563 \\
\hline & & & & & & & & & 2.5264 & 1.1 & 2.7 & 2.7 & 2.522 \\
\hline & & & & & & & & & 2.4848 & 0.1 & 2.1 & $\mathrm{~N}(14)$ & 2.5 \\
\hline & & & & & & & & & 2.45 & 0.3 & 2.2 & 2.2 & 2.45 \\
\hline & & & & & & & & & & & & $\mathrm{N}(10)$ & 2.4007 \\
\hline \multirow[t]{3}{*}{2.3744} & 21.4 & 18.5 & 2.3779 & 21.1 & 19.8 & 2.3791 & 21.8 & 19.5 & 2.3767 & 20.7 & 19.6 & $S(16)$ & 2.373 \\
\hline & & & & & & 2.3505 & 0.5 & 2.0 & 2.3503 & 0.9 & 2.4 & $\mathrm{~N}(35)$ & 2.3395 \\
\hline & & & & & & & & & 2.3102 & 0.4 & 2.2 & $\mathrm{~N}(25)$ & 2.3074 \\
\hline \multirow[t]{5}{*}{2.2213} & 1.0 & 2.2 & 2.2234 & 1.3 & 2.8 & 2.2246 & 1.7 & 2.6 & 2.2205 & 1.2 & 2.8 & $S(1)$ & 2.219 \\
\hline & & & & & & & & & 2.2027 & 0.2 & 2.1 & 2.1 & 2.202 \\
\hline & & & & & & & & & & & & $\mathrm{N}(5)$ & 2.163 \\
\hline & & & & & & 2.1207 & 0.3 & 1.9 & & & & $\mathrm{~N}(7)$ & 2.1188 \\
\hline & & & & & & & & & & & & $\mathrm{N}(5)$ & 2.0938 \\
\hline \multirow[t]{2}{*}{2.0933} & 30.2 & 23.8 & 2.096 & 31.6 & 25.5 & 2.097 & 32.2 & 28 & 2.0951 & 32.1 & 28.2 & $S(20)$ & 2.093 \\
\hline & & & & & & & & & 2.0728 & 0.5 & 2.3 & 2.3 & 2.071 \\
\hline 2.0061 & 3.4 & 3.0 & 2.006 & 3.7 & 3.3 & 2.0027 & 2.4 & 2.7 & 1.9987 & 3.6 & 3.1 & $\mathrm{H}(55)$ & 1.994 \\
\hline \multirow[t]{2}{*}{1.9853} & 5.7 & 5.2 & 1.9869 & 5.0 & 5.4 & 1.9892 & 5.6 & 5.3 & 1.9876 & 5.5 & 5.3 & $\mathrm{~S}(3)$ & 1.985 \\
\hline & & & & & & & & & 1.9378 & 0.1 & 1.8 & $\mathrm{~N}(6)$ & 1.9313 \\
\hline \multirow[t]{2}{*}{1.8923} & 4.3 & 4.4 & 1.8939 & 4.4 & 4.8 & 1.8959 & 4.3 & 4.7 & 1.8939 & 4.1 & 4.8 & $S(3)$ & 1.893 \\
\hline & & & & & & & & & & & & $\mathrm{N}(2)$ & 1.8411 \\
\hline \multirow[t]{2}{*}{1.8124} & 3.5 & 3.6 & 1.8131 & 3.7 & 3.6 & 1.8145 & 3.6 & 4.1 & 1.8126 & 3.7 & 4.3 & $S(2)$ & 1.8122 \\
\hline & & & & & & & & & & & & $\mathrm{N}(5)$ & 1.7923 \\
\hline \multirow[t]{6}{*}{1.7385} & 4 & 3.7 & 1.7421 & 4.7 & 4.4 & 1.7439 & 4.2 & 4.2 & 1.7417 & 3.5 & 4.4 & $S(2)$ & 1.7413 \\
\hline & & & & & & & & & & & & 1.4 & 1.720 \\
\hline & & & & & & 1.6512 & 0.3 & 1.3 & & & & $\mathrm{~N}(5)$ & 1.6942 \\
\hline & & & 1.6352 & 1.8 & 2.1 & 1.6328 & 0.8 & 1.7 & 1.6331 & 0.6 & 2.1 & $\mathrm{~N}(6)$ & 1.6346 \\
\hline & & & & & & & & & & & & $\mathrm{H}(15)$ & 1.628 \\
\hline & & & 1.621 & 3.2 & 4 & 1.6217 & 3.8 & 3.7 & 1.6211 & 3.1 & 3.8 & $S(2)$ & 1.621 \\
\hline \multirow[t]{2}{*}{1.6189} & 2.6 & 3.0 & & & & & & & & & & $\mathrm{~N}(8)$ & 1.615 \\
\hline & & & & & & & & & & & & $\mathrm{N}(4)$ & 1.6002 \\
\hline \multirow[t]{3}{*}{1.5672} & 12.5 & 9.1 & 1.5691 & 12.9 & 10.1 & 1.5706 & 12.4 & 10.0 & 1.57 & 12.6 & 9.9 & $\mathrm{~S}(5)$ & 1.5696 \\
\hline & & & & & & & & & & & & $\mathrm{N}(14)$ & 1.5614 \\
\hline & & & & & & & & & 1.5309 & 0.2 & 1.8 & 1.8 & 1.531 \\
\hline 1.5204 & 6.6 & 5.5 & 1.5226 & 6.8 & 5.3 & 1.5235 & 6.2 & 5.1 & 1.5227 & 6.6 & 6.3 & $\mathrm{~S}(3)$ & 1.5227 \\
\hline
\end{tabular}


Table 11. (continued)

\begin{tabular}{|c|c|c|c|c|c|c|c|c|c|c|c|c|c|}
\hline \multicolumn{3}{|c|}{ G1A } & \multicolumn{3}{|c|}{ G2A } & \multicolumn{3}{|c|}{ G4A } & \multicolumn{3}{|c|}{ G5A } & \multicolumn{2}{|c|}{ Reference phases } \\
\hline$d(\AA)$ & $\begin{array}{c}\text { I\% peak } \\
\text { area } \\
\end{array}$ & $\begin{array}{c}\text { I\% peak } \\
\text { height }\end{array}$ & $d(\AA)$ & $\begin{array}{c}\text { I\% peak } \\
\text { area } \\
\end{array}$ & $\begin{array}{c}\text { I\% peak } \\
\text { height }\end{array}$ & $d(\AA)$ & $\begin{array}{c}1 \% \text { peak } \\
\text { area }\end{array}$ & $\begin{array}{c}1 \% \text { peak } \\
\text { height }\end{array}$ & $d(\AA)$ & $\begin{array}{c}1 \% \text { peak } \\
\text { area }\end{array}$ & $\begin{array}{c}1 \% \text { peak } \\
\text { height }\end{array}$ & $\begin{array}{c}1 \% \text { peak } \\
\text { height }\end{array}$ & $d(\AA)$ \\
\hline \multirow[t]{3}{*}{1.478} & 9.5 & 6.7 & 1.4789 & 9.7 & 7.3 & 1.4802 & 10.6 & 7.6 & 1.4797 & 10.3 & 8.3 & $\mathrm{~S}(4)$ & 1.4797 \\
\hline & & & & & & & & & & & & $\mathrm{N}(5)$ & 1.4687 \\
\hline & & & & & & & & & & & & $\mathrm{N}(3)$ & 1.4555 \\
\hline \multirow[t]{5}{*}{1.4376} & 9.7 & 7.1 & 1.4395 & 10.9 & 7.7 & 1.4411 & 9.9 & 8.2 & 1.44 & 9.4 & 8.2 & $S(5)$ & 1.4404 \\
\hline & & & & & & & & & & & & $\mathrm{N}(7)$ & 1.4282 \\
\hline & & & & & & & & & & & & $\mathrm{H}(6)$ & 1.41 \\
\hline & & & 1.4019 & 0.5 & 1.7 & 1.4043 & 0.7 & 1.7 & 1.4033 & 1 & 1.9 & $\mathrm{~S}(1)$ & 1.4038 \\
\hline & & & & & & 1.3704 & 3.4 & 3.6 & 1.383 & 0.3 & 1.7 & $\mathrm{~N}(6)$ & 1.3865 \\
\hline 1.3676 & 4.3 & 3.7 & 1.369 & 4.5 & 3.8 & 1.3663 & 2.6 & 2.5 & 1.3697 & 3.9 & 4 & $\mathrm{~S}(2)$ & 1.3699 \\
\hline \multirow[t]{2}{*}{1.336} & 5 & 3.8 & 1.3376 & 4.8 & 3.8 & 1.3389 & 3.8 & 3.7 & 1.3382 & 4.3 & 4.1 & $\mathrm{~S}(2)$ & 1.3385 \\
\hline & & & & & & & & & & & & 3.8 & 1.336 \\
\hline \multirow[t]{2}{*}{1.3061} & 4.1 & 3.5 & 1.3074 & 5.2 & 3.4 & 1.3092 & 3.2 & 4.1 & 1.3092 & 3.8 & 3.7 & $\mathrm{~S}(2)$ & 1.3091 \\
\hline & & & & & & & & & 1.3052 & 2 & 2.5 & 2.5 & 1.305 \\
\hline \multirow[t]{5}{*}{1.2796} & 1.7 & 2.6 & 1.2805 & 2.8 & 2.8 & 1.2812 & 3.1 & 3 & 1.2806 & 2.5 & 3.3 & $\mathrm{~S}(2)$ & 1.2814 \\
\hline & & & & & & & & & & & & $\mathrm{N}(6)$ & 1.279 \\
\hline & & & 1.2644 & 0.8 & 1.5 & & & & 1.2639 & 0.7 & 1.6 & $S(1)$ & 1.2684 \\
\hline & & & & & & & & & & & & $S(1)$ & 1.2555 \\
\hline & & & 1.2299 & 0.7 & 1.5 & 1.2309 & 0.6 & 1.3 & 1.2303 & 0.4 & 1.5 & $\mathrm{~N}(4)$ & 1.2347 \\
\hline 1.2056 & 7.4 & 5.1 & 1.2066 & 8.5 & 5.5 & 1.2079 & 7.4 & 6.2 & 1.2076 & 8.1 & 6.6 & $\mathrm{~S}(3)$ & 1.2081 \\
\hline
\end{tabular}

${ }^{\mathrm{a}} \mathrm{S}$ = sodalite, $\mathrm{N}=$ nepheline, $\mathrm{H}=$ halite; the relative heights for reference patterns are given in parentheses. 
Table 12. Results of XRD analysis of salt-loaded CWF material S1B

\begin{tabular}{|c|c|c|c|c|c|c|c|c|c|c|c|c|c|c|}
\hline \multicolumn{3}{|c|}{ S1B } & \multicolumn{2}{|c|}{ Reference phases $^{a}$} & \multicolumn{3}{|c|}{ S1B } & \multicolumn{2}{|c|}{ Reference phases } & \multicolumn{3}{|c|}{ S1B } & \multicolumn{2}{|c|}{ Reference phases } \\
\hline$d(\AA)$ & $\begin{array}{c}1 \% \text { peak } \\
\text { area }\end{array}$ & $\begin{array}{c}1 \% \text { peak } \\
\text { height }\end{array}$ & $\begin{array}{c}1 \% \text { peak } \\
\text { height }\end{array}$ & $d(\AA)$ & $d(\AA)$ & $\begin{array}{c}\% \text { peak } \\
\text { area }\end{array}$ & $\begin{array}{c}\text { I\% peak } \\
\text { height }\end{array}$ & $\begin{array}{c}1 \% \text { peak } \\
\text { height }\end{array}$ & $d(\AA)$ & $d(\AA)$ & $\begin{array}{c}1 \% \text { peak } \\
\text { area }\end{array}$ & $\begin{array}{c}\% \text { peak } \\
\text { height }\end{array}$ & $\begin{array}{c}\text { I\% peak } \\
\text { height }\end{array}$ & $d(\AA)$ \\
\hline & & & 2.4 & 8.397 & 3.0215 & 26.2 & 24.1 & $\mathrm{~N}(100)$ & 3.0059 & & & & 1.4 & 1.720 \\
\hline & & & 2.4 & 8.112 & 2.8989 & 11.0 & 9.7 & $\mathrm{~N}(35)$ & 2.8864 & 1.7131 & 0.8 & 0.6 & 0.6 & 1.705 \\
\hline & & & 2.1 & 7.847 & & & & $\mathrm{H}(100)$ & 2.821 & 1.6978 & 2.4 & 1.3 & $\mathrm{~N}(5)$ & 1.6942 \\
\hline & & & 2.0 & 7.599 & 2.8237 & 9.6 & 8.9 & $\mathrm{~S}(8)$ & 2.807 & 1.6391 & 1.9 & 1.2 & $\mathrm{~N}(6)$ & 1.6346 \\
\hline & & & 2.1 & 7.233 & & & & 2.6 & 2.696 & & & & $\mathrm{H}(15)$ & 1.628 \\
\hline & & & 1.9 & 6.920 & & & & 2.5 & 2.665 & 1.6242 & 6.4 & 2.8 & $\mathrm{~S}(2)$ & 1.621 \\
\hline 6.3571 & 25.7 & 23.0 & $\mathrm{~S}(40)$ & 6.28 & 2.5758 & 25.1 & 19.5 & $\mathrm{~S}(16)$ & 2.563 & & & & $\mathrm{~N}(8)$ & 1.615 \\
\hline & & & 2.2 & 5.277 & & & & 2.7 & 2.526 & 1.602 & 2.0 & 1.1 & $\mathrm{~N}(4)$ & 1.6002 \\
\hline & & & 1.9 & 5.156 & 2.5089 & 4.6 & 3.3 & $\mathrm{~N}(14)$ & 2.5 & 1.573 & 13.5 & 9.9 & $\mathrm{~S}(5)$ & 1.5696 \\
\hline 5.0462 & 3.0 & 2.8 & $\mathrm{~N}(10)$ & 5.0058 & 2.4428 & 0.3 & 0.4 & 2.2 & 2.45 & 1.5619 & 12.6 & 4.6 & $\mathrm{~N}(14)$ & 1.5614 \\
\hline & & & 2.5 & 4.789 & 2.41 & 4.8 & 3.0 & $\mathrm{~N}(10)$ & 2.4007 & & & & 1.8 & 1.531 \\
\hline & & & 2.9 & 4.763 & 2.3829 & 21.2 & 20.4 & $\mathrm{~S}(16)$ & 2.373 & 1.5263 & 8.0 & 5.8 & $\mathrm{~S}(3)$ & 1.5227 \\
\hline & & & 2.9 & 4.658 & & & & & 2.348 & 1.4831 & 10.5 & 8.3 & $\mathrm{~S}(4)$ & 1.4797 \\
\hline & & & 3.2 & 4.554 & 2.3505 & 12.6 & 11.6 & $\mathrm{~N}(35)$ & 2.3395 & 1.4725 & 2.3 & 1.4 & $N(5)$ & 1.4687 \\
\hline 4.48 & 7.3 & 6.4 & $\mathrm{~S}(5)$ & 4.44 & 2.3156 & 8.1 & 6.7 & $\mathrm{~N}(25)$ & 2.3074 & 1.4589 & 0.7 & 0.7 & $\mathrm{~N}(3)$ & 1.4555 \\
\hline 4.3586 & 8.1 & 6.1 & $\mathrm{~N}(35)$ & 4.3335 & 2.2286 & 1.5 & 1.2 & $\mathrm{~S}(1)$ & 2.219 & 1.4431 & 10.5 & 8.7 & $S(5)$ & 1.4404 \\
\hline & & & & 4.191 & & & & 2.1 & 2.203 & 1.4317 & 4.2 & 2.4 & $\mathrm{~N}(7)$ & 1.4282 \\
\hline 4.211 & 14.4 & 14.7 & $\mathrm{~N}(80)$ & 4.1766 & 2.1721 & 2.2 & 1.0 & $\mathrm{~N}(5)$ & 2.163 & & & & $\mathrm{H}(6)$ & 1.41 \\
\hline & & & 3.8 & 4.103 & 2.1272 & 3.0 & 2.4 & $\mathrm{~N}(7)$ & 2.1188 & 1.4067 & 1.1 & 0.7 & $S(1)$ & 1.4038 \\
\hline & & & $\mathrm{S}(1)$ & 3.97 & & & & $\mathrm{~N}(5)$ & 2.0938 & 1.3938 & 3.1 & 1.0 & $\mathrm{~N}(6)$ & 1.3865 \\
\hline 3.8702 & 23.2 & 21.5 & $\mathrm{~N}(100)$ & 3.8438 & 2.0999 & 39.8 & 32.3 & $\mathrm{~S}(20)$ & 2.093 & 1.3876 & 6.7 & 3.7 & $S(2)$ & 1.3699 \\
\hline & & & $\mathrm{N}(2)$ & 3.7614 & 1.9919 & 6.6 & 5.7 & 2.3 & 2.073 & 1.3729 & 6.1 & 4.1 & $S(2)$ & 1.3385 \\
\hline 3.6509 & 100 & 100 & $S(100)$ & 3.624 & 1.9372 & 4.4 & 2.5 & $\mathrm{H}(55)$ & 1.994 & 1.3409 & 4.8 & 3.2 & 3.8 & 1.336 \\
\hline 3.6109 & 1.0 & 0.8 & 4.4 & 3.571 & 1.9256 & 2.7 & 0.9 & $\mathrm{~S}(3)$ & 1.985 & 1.3165 & 4.7 & 1.3 & $\mathrm{~S}(2)$ & 1.3091 \\
\hline & & & 3.5 & 3.466 & 1.899 & 6.6 & 3.9 & $\mathrm{~N}(6)$ & 1.9313 & 1.3111 & 7.1 & 3.2 & 2.5 & 1.305 \\
\hline & & & 3.5 & 3.378 & 1.8865 & 3.1 & 1.1 & $S(3)$ & 1.893 & 1.2832 & 6.0 & 2.8 & $\mathrm{~S}(2)$ & 1.2814 \\
\hline & & & 3.3 & 3.323 & 1.8455 & 1.0 & 0.7 & $\mathrm{~N}(2)$ & 1.8411 & & & & $\mathrm{~N}(6)$ & 1.279 \\
\hline 3.2901 & 19.3 & 16.7 & $\mathrm{~N}(70)$ & 3.2731 & 1.8179 & 4.3 & 3.5 & $S(2)$ & 1.8122 & 1.2685 & 1.0 & 0.9 & $S(1)$ & 1.2684 \\
\hline & & & $\mathrm{H}(13)$ & 3.26 & 1.7978 & 2.2 & 1.5 & $\mathrm{~N}(5)$ & 1.7923 & 1.2376 & 1.4 & 0.6 & $\mathrm{~S}(1)$ & 1.2555 \\
\hline 3.2267 & 0.2 & 0.4 & $3.2,2.9$ & 3.149 & 1.7642 & 0.7 & 0.6 & 0.6 & 1.759 & 1.2328 & 1.2 & 0.6 & $\mathrm{~N}(4)$ & 1.2347 \\
\hline 3.0621 & 5.0 & 3.4 & $\mathrm{~N}(18)$ & 3.0461 & 1.7465 & 3.5 & 3.2 & $S(2)$ & 1.7413 & 1.2097 & 10.3 & 7.0 & $S(3)$ & 1.2081 \\
\hline
\end{tabular}

${ }^{\mathrm{a}} \mathrm{S}=$ sodalite, $\mathrm{N}=$ nepheline, $\mathrm{H}=$ halite; the relative heights for reference patterns are given in parentheses. 
Table 13. Compilation of relative peak heights used to identify sodalite, nepheline, and halite in salt-loaded CWF materials, in percent

\begin{tabular}{|c|c|c|c|c|c|c|c|c|c|c|c|c|c|c|}
\hline $\begin{array}{c}d \text {-spacing, } \\
\AA\end{array}$ & $\begin{array}{c}\% \text { peak } \\
\text { height }\end{array}$ & $\mathrm{S} 1 \mathrm{~A}$ & S1B & $\mathrm{S} 2 \mathrm{C}$ & S3A & S3B & S3C & S3E & S4A & S5B & G1A & G2A & G4A & G5A \\
\hline \multicolumn{15}{|c|}{ Halite } \\
\hline 3.26 & 13 & $\mathrm{nd}^{\mathrm{a}}$ & nd & nd & nd & nd & 3.1 & nd & nd & nd & nd & nd & nd & 3.9 \\
\hline 2.821 & 100 & nd & nd & nd & 5.3 & 4.7 & 5.0 & 4.3 & 6.8 & 8.2 & 6.5 & 6.7 & 5.4 & 6.9 \\
\hline 1.994 & 55 & nd & nd & nd & 2.8 & 2.0 & 2.6 & 2.5 & 3.0 & 4.4 & 3.0 & 3.3 & 2.7 & 3.1 \\
\hline 1.628 & 15 & nd & nd & nd & nd & nd & $\mathrm{nd}$ & nd & nd & nd & $\mathrm{nd}$ & $\mathrm{nd}$ & $\mathrm{nd}$ & nd \\
\hline 1.41 & 6 & nd & nd & nd & nd & nd & nd & nd & nd & 1.5 & nd & nd & nd & nd \\
\hline \multicolumn{15}{|c|}{ Sodalite } \\
\hline 6.28 & 40 & 25.6 & 23.0 & 24.2 & 25.4 & 24.0 & 26.0 & 25.9 & 26.5 & 28.5 & 31.5 & 27.5 & 27.0 & 25.5 \\
\hline 3.624 & 100 & 100 & 100 & 100 & 100 & 100 & 100 & 100 & 100 & 100 & 100 & 100 & 100 & 100 \\
\hline 2.563 & 16 & 19.8 & 19.5 & 21.2 & 20.8 & 20.2 & 21.2 & 19.9 & 19.0 & 20.0 & 19.8 & 20.3 & 20.2 & 20.1 \\
\hline 2.373 & 16 & 20.1 & 20.4 & 19.9 & 19.8 & 20.7 & 20.5 & 20.5 & 19.7 & 19.3 & 18.5 & 19.8 & 19.5 & 19.6 \\
\hline 2.093 & 20 & 29.7 & 32.3 & 29.7 & 28.7 & 31.1 & 30.8 & 27.9 & 27.9 & 24.0 & 23.8 & 25.5 & 28.0 & 28.2 \\
\hline \multicolumn{15}{|c|}{ Nepheline } \\
\hline 4.3335 & 35 & 9.5 & 6.1 & 4.1 & nd & nd & nd & nd & nd & nd & nd & 2.8 & nd & 3.5 \\
\hline 4.1766 & 80 & 17.0 & 14.7 & 6.2 & nd & nd & nd & 3 & 3.1 & nd & nd & nd & nd & 3.8 \\
\hline 3.8438 & 100 & 23.1 & 21.5 & 8.1 & 3.7 & nd & 3.6 & 3.5 & 3.4 & nd & nd & 3.3 & 3.8 & nd \\
\hline 3.2731 & 70 & 17.6 & 16.7 & 6.8 & 3.9 & 0.8 & $\mathrm{nd}$ & 3.6 & 3.8 & 4.4 & 3.4 & 3.7 & 4.0 & 4.7 \\
\hline 3.0059 & 100 & 23.8 & 24.1 & 8.3 & 3.3 & 0.9 & 3.0 & 3.0 & 3.2 & 3.6 & 2.9 & 3.1 & 3.5 & 3.8 \\
\hline 2.8864 & 35 & 11.8 & 9.7 & 4.8 & 2.7 & 0.5 & 2.5 & nd & nd & nd & $\mathrm{nd}$ & nd & 2.9 & 3.3 \\
\hline 2.3395 & 35 & 11.6 & 11.6 & 3.9 & nd & 0.7 & nd & nd & nd & nd & nd & nd & 2.0 & 2.4 \\
\hline
\end{tabular}

a "nd" indicates that a quantifiable peak was not detected. 
Table 14. Compilation of relative peak areas used to identify relative amounts of sodalite, nepheline, and halite in the different salt-loaded CWF materials, in percent

\begin{tabular}{|c|c|c|c|c|c|c|c|c|c|c|c|c|c|}
\hline $\begin{array}{c}d \text {-spacing, } \\
\AA\end{array}$ & S1A & S1B & $\mathrm{S} 2 \mathrm{C}$ & S3A & S3B & $\mathrm{S} 3 \mathrm{C}$ & S3E & S4A & S5B & G1A & G2A & G4A & G5A \\
\hline \multicolumn{14}{|c|}{ Halite } \\
\hline 3.26 & $\mathrm{nd}^{\mathrm{a}}$ & nd & nd & nd & nd & 0.3 & nd & nd & nd & nd & nd & nd & 0.2 \\
\hline 2.821 & nd & nd & nd & 9.5 & 12.7 & 8.7 & 9.2 & 9.9 & 11.7 & 7.2 & 7.4 & 9.9 & 6.8 \\
\hline 1.994 & nd & nd & nd & 2.2 & 2.9 & 2.8 & 2.1 & 3.2 & 5.4 & 3.4 & 3.7 & 2.4 & 3.6 \\
\hline 1.628 & nd & nd & nd & nd & nd & nd & nd & nd & nd & nd & nd & nd & nd \\
\hline 1.41 & nd & nd & nd & nd & nd & nd & $\mathrm{nd}$ & nd & 0.3 & nd & nd & $\mathrm{nd}$ & nd \\
\hline \multicolumn{14}{|c|}{ Sodalite } \\
\hline 6.28 & 24.2 & 25.7 & 27.4 & 24.5 & 26.1 & 24.9 & 25.9 & 26.7 & 27.8 & 29.3 & 26.5 & 26.4 & 24.1 \\
\hline 3.624 & 100 & 100 & 100 & 100 & 100 & 100 & 100 & 100 & 100 & 100 & 100 & 100 & 100 \\
\hline 2.563 & 24.9 & 25.1 & 20.8 & 20.0 & 20.7 & 19.6 & 19.9 & 19.7 & 20.0 & 21.7 & 21.2 & 19.8 & 19.7 \\
\hline 2.373 & 21.0 & 21.2 & 20.4 & 21.6 & 21.1 & 21.6 & 21.1 & 20.7 & 20.5 & 21.4 & 21.1 & 21.8 & 20.7 \\
\hline 2.093 & 39.8 & 39.8 & 34.6 & 32.4 & 32.4 & 32.8 & 32.3 & 32.4 & 29.9 & 30.2 & 31.6 & 32.2 & 32.1 \\
\hline \multicolumn{14}{|c|}{ Nepheline } \\
\hline 4.3335 & 8.1 & 8.1 & 1.3 & nd & nd & nd & nd & nd & nd & nd & 0.2 & nd & 0.5 \\
\hline 4.1766 & 12.4 & 14.4 & 2.1 & nd & 0.5 & nd & 0.2 & 1.2 & nd & nd & nd & nd & 0.2 \\
\hline 3.8438 & 20.4 & 23.2 & 5.3 & 0.7 & 1.2 & 0.7 & 0.2 & 0.3 & nd & nd & 0.1 & 0.9 & nd \\
\hline 3.2731 & 16.6 & 19.3 & 3.6 & 1.0 & 1.7 & 0.7 & 0.6 & 0.7 & 0.7 & 0.6 & 0.7 & 1.6 & 0.9 \\
\hline 3.0059 & 23.9 & 26.2 & 6.1 & 0.5 & 1.5 & 0.5 & 0.5 & 0.4 & 0.3 & 0.2 & 0.2 & 0.3 & 0.4 \\
\hline 2.8864 & 10.6 & 11.0 & 2.3 & 0.2 & 0.7 & 0.2 & nd & nd & nd & nd & nd & 0.2 & 1.3 \\
\hline 2.3395 & 9.8 & 12.6 & 0.8 & nd & 0.9 & nd & nd & nd & nd & nd & nd & 0.5 & 0.9 \\
\hline
\end{tabular}

a "nd" indicates that a quantifiable peak was not detected at this $d$-spacing. 
Table 15. Test data for rapid water soluble tests with salt-loaded CWF materials

\begin{tabular}{|c|c|c|c|c|c|c|c|c|c|c|c|c|}
\hline $\begin{array}{c}\text { Material } \\
\text { ID }\end{array}$ & $\begin{array}{c}\text { Beaker } \\
\text { tare, } \mathrm{g}\end{array}$ & $\begin{array}{c}\text { Beaker } \\
+ \text { CWF, } \\
g\end{array}$ & CWF, g & $\begin{array}{c}\text { Target } \\
\text { mass } \\
\text { water, g }\end{array}$ & $\begin{array}{c}\text { Actual } \\
\text { mass } \\
\text { water, g }\end{array}$ & $\begin{array}{c}\text { Water/CWF, } \\
\mathrm{mL} / \mathrm{g}\end{array}$ & $\begin{array}{c}\text { Bottle } 1 \\
\text { tare, } g\end{array}$ & $\begin{array}{c}\text { Bottle } 1 \\
+ \text { RWS } \\
g\end{array}$ & \begin{tabular}{|c|} 
RWS \\
solution in \\
bottle $1, \mathrm{~g}$
\end{tabular} & $\begin{array}{c}\text { Bottle } 2 \\
\text { tare, } \mathrm{g}\end{array}$ & $\begin{array}{c}\text { Bottle } 2 \\
+ \text { RWS } \\
g\end{array}$ & \begin{tabular}{|c} 
RWS \\
solution in \\
bottle $2, \mathrm{~g}$ \\
\end{tabular} \\
\hline S1A & 28.85 & 33.96 & 5.11 & 51.10 & 51.10 & 10.00 & 10.90 & 22.88 & 11.98 & 11.00 & 21.00 & 10.00 \\
\hline S2C & 28.88 & 34.39 & 5.51 & 55.10 & 55.23 & 10.02 & 11.02 & 22.88 & 11.86 & 11.03 & 22.72 & 11.69 \\
\hline S3A & 29.75 & 34.69 & 4.94 & 49.40 & 49.50 & 10.02 & 10.99 & 22.57 & 11.58 & 11.03 & 22.91 & 11.88 \\
\hline S3C & 29.52 & 36.51 & 6.99 & 69.90 & 60.79 & 8.70 & 10.96 & 22.84 & 11.88 & 11.01 & 23.34 & 12.33 \\
\hline S3E & 29.80 & 35.45 & 5.65 & 56.50 & 56.51 & 10.00 & 10.78 & 22.46 & 11.68 & 11.05 & 23.55 & 12.50 \\
\hline S4A & 29.63 & 34.82 & 5.19 & 51.90 & 52.00 & 10.02 & 11.02 & 23.04 & 12.02 & 10.98 & 23.29 & 12.31 \\
\hline S5B & 29.78 & 34.85 & 5.07 & 50.70 & 50.72 & 10.00 & 11.07 & 23.76 & 12.69 & 10.85 & 22.91 & 12.06 \\
\hline G1A & 28.75 & 34.18 & 5.43 & 54.30 & 54.38 & 10.01 & 11.01 & 22.46 & 11.45 & 10.99 & 22.97 & 11.98 \\
\hline G2A & 29.76 & 35.32 & 5.56 & 55.60 & 56.03 & 10.08 & 11.05 & 21.76 & 10.71 & 10.97 & 22.50 & 11.53 \\
\hline G4A & 29.45 & 34.58 & 5.13 & 51.30 & 51.34 & 10.01 & 11.06 & 22.77 & 11.71 & 11.00 & 22.81 & 11.81 \\
\hline G5A & 30.24 & 35.71 & 5.47 & 54.70 & 55.12 & 10.08 & 10.93 & 23.28 & 12.35 & 10.96 & 22.88 & 11.92 \\
\hline
\end{tabular}


Table 16. Results of rapid water soluble tests and free chloride measurements with salt-loaded CWF materials

\begin{tabular}{|c|c|c|c|c|c|c|c|c|}
\hline \multirow{2}{*}{ Material ID } & \multicolumn{3}{|c|}{$\mathrm{Cl}^{-}$in RWS, mg/L } & \multirow{2}{*}{$\mathrm{NL}(\mathrm{Cl}), \mathrm{g} / \mathrm{m}^{2}$} & \multicolumn{4}{|c|}{$\%$ free chloride measurement } \\
\hline & Bottle 1 & Bottle 2 & Average & & 1 & 2 & 3 & Average \\
\hline S1A & 2.19 & 2.02 & 2.105 & 0.0336 & 0.042 & 0.32 & 0.13 & 0.16 \\
\hline S2C & 28.6 & 27.8 & 28.2 & 0.352 & 0.017 & 0.026 & 0.031 & 0.025 \\
\hline S3A & 278 & 271 & 274.5 & 2.77 & 0.19 & 0.42 & 0.47 & 0.36 \\
\hline S3C & 313 & 314 & 313.5 & 2.71 & 0.040 & 0.061 & 0.065 & 0.055 \\
\hline S3E & 305 & 303 & 304 & 2.85 & 0.031 & 0.045 & 0.068 & 0.048 \\
\hline S4A & 469 & 476 & 472.5 & 4.11 & 0.020 & 0.015 & 0.060 & 0.032 \\
\hline S5B & 1030 & 1060 & 1045 & 8.25 & 0.026 & 0.053 & 0.22 & 0.10 \\
\hline G1A & 1430 & 1440 & 1435 & 11.5 & 0.040 & 0.14 & 0.15 & 0.11 \\
\hline G2A & 954 & 985 & 969.5 & 6.98 & 0.056 & 0.12 & 0.15 & 0.11 \\
\hline G4A & 305 & 301 & 303 & 2.51 & 0.020 & 0.042 & 0.089 & 0.050 \\
\hline G5A & 342 & 345 & 343.5 & 3.41 & 0.042 & 0.045 & 0.13 & 0.072 \\
\hline
\end{tabular}


Table 17. Test data for 7-day PCTs with salt-loaded CWF materials

\begin{tabular}{|c|c|c|c|c|c|c|c|c|c|c|c|c|}
\hline \multirow[b]{2}{*}{ Test no. } & \multirow{2}{*}{$\begin{array}{c}\text { CWF } \\
\text { mass, g }\end{array}$} & \multirow{2}{*}{$\begin{array}{l}\text { Water } \\
\text { mass, } g\end{array}$} & \multirow[b]{2}{*}{$\mathrm{S} / \mathrm{V}, \mathrm{m}^{-1}$} & \multicolumn{4}{|c|}{ Test Vessel } & \multirow{2}{*}{$\begin{array}{l}\mathrm{pH} \text { at } \\
25^{\circ} \mathrm{C}\end{array}$} & \multicolumn{3}{|c|}{ Solution bottle } & \multirow{2}{*}{$\begin{array}{c}\text { Dilution } \\
\text { factor }\end{array}$} \\
\hline & & & & $\begin{array}{c}\text { Vessel } \\
\text { no. }\end{array}$ & $\begin{array}{c}\text { Mass in, } \\
\mathrm{g}\end{array}$ & $\begin{array}{c}\text { Mass out, } \\
\mathrm{g}\end{array}$ & $\begin{array}{c}\text { Change, } \\
\text { g }\end{array}$ & & $\begin{array}{c}\text { tare, } \\
\mathrm{g}\end{array}$ & $\begin{array}{c}+ \text { test soln., } \\
\mathrm{g}\end{array}$ & $\begin{array}{l}+ \text { test soln. } \\
+\mathrm{HNO}_{3}, \mathrm{~g}\end{array}$ & \\
\hline PS1A-1 & 1.15 & 11.49 & 2302 & 749 & 323.85 & 323.84 & -0.01 & 8.64 & 11.13 & 21.44 & 31.18 & 1.9447 \\
\hline PS1A-2 & 1.11 & 11.10 & 2300 & 6 & 323.71 & 323.71 & 0.00 & 8.61 & 11.06 & 21.16 & 31.32 & 2.0059 \\
\hline PS1A-3 & 1.20 & 12.01 & 2298 & 960 & 325.27 & 325.26 & -0.01 & 8.59 & 11.10 & 20.73 & 30.96 & 2.0623 \\
\hline PS2C-1 & 1.09 & 10.90 & 2300 & 554 & 324.90 & 324.90 & 0.00 & 8.47 & 11.09 & 21.08 & 31.11 & 2.0040 \\
\hline PS2C-2 & 1.04 & 10.39 & 2302 & 433 & 325.83 & 325.83 & 0.00 & 8.49 & 11.08 & 19.66 & 31.20 & 2.3450 \\
\hline PS2C-3 & 1.19 & 11.89 & 2302 & 920 & 325.01 & 325.01 & 0.00 & 8.51 & 11.19 & 21.92 & 31.13 & 1.8583 \\
\hline PS3A-1 & 1.20 & 12.00 & 2300 & 493 & 329.18 & 329.18 & 0.00 & 8.45 & 11.14 & 21.98 & 31.27 & 1.8570 \\
\hline PS3A-2 & 1.11 & 11.12 & 2296 & 417 & 327.98 & 327.98 & 0.00 & 8.44 & 11.16 & 21.07 & 31.18 & 2.0202 \\
\hline PS3A-3 & 1.08 & 10.82 & 2296 & 953 & 326.28 & 326.27 & -0.01 & 8.45 & 11.14 & 20.95 & 30.66 & 1.9898 \\
\hline PS3C-1 & 1.25 & 12.51 & 2298 & 906 & 326.76 & 326.77 & 0.01 & 8.43 & 11.15 & 22.45 & 30.99 & 1.7558 \\
\hline PS3C-2 & 1.22 & 12.22 & 2296 & 970 & 325.27 & 325.27 & 0.00 & 8.51 & 11.19 & 22.32 & 30.51 & 1.7358 \\
\hline PS3C-3 & 1.13 & 11.31 & 2298 & 911 & 325.71 & 325.71 & 0.00 & 8.49 & 11.18 & 21.34 & 31.18 & 1.9685 \\
\hline PS3E-1 & 1.15 & 11.49 & 2302 & 738 & 326.56 & 326.56 & 0.00 & 8.42 & 11.15 & 21.58 & 31.05 & 1.9080 \\
\hline PS3E-2 & 1.14 & 11.42 & 2296 & 733 & 329.16 & 329.16 & 0.00 & 8.42 & 11.07 & 21.44 & 30.20 & 1.8447 \\
\hline PS3E-3 & 1.17 & 11.71 & 2298 & 711 & 326.43 & 326.43 & 0.00 & 8.40 & 11.10 & 21.59 & 31.19 & 1.9152 \\
\hline PS4A-1 & 1.14 & 11.41 & 2298 & 490 & 326.62 & 326.62 & 0.00 & 8.36 & 11.16 & 21.69 & 30.27 & 1.8148 \\
\hline PS4A-2 & 1.16 & 11.61 & 2298 & 159 & 328.12 & 328.13 & 0.01 & 8.29 & 11.14 & 21.74 & 31.87 & 1.9557 \\
\hline PS4A-3 & 1.13 & 11.33 & 2294 & 47 & 326.15 & 326.15 & 0.00 & 8.33 & 11.11 & 21.38 & 30.41 & 1.8793 \\
\hline PS5B-1 & 1.08 & 10.81 & 2298 & 78 & 325.35 & 325.35 & 0.00 & 8.48 & 11.15 & 20.95 & 31.16 & 2.0418 \\
\hline PS5B-2 & 1.16 & 11.63 & 2294 & 406 & 324.52 & 324.52 & 0.00 & 8.41 & 11.16 & 21.57 & 31.18 & 1.9232 \\
\hline PS5B-3 & 1.03 & 10.30 & 2300 & 760 & 327.28 & 327.28 & 0.00 & 8.39 & 11.13 & 20.44 & 31.30 & 2.1665 \\
\hline PG1A-1 & 1.16 & 11.64 & 2292 & 169 & 326.84 & 326.84 & 0.00 & 8.40 & 11.15 & 21.66 & 31.28 & 1.9153 \\
\hline PG1A-2 & 1.17 & 11.73 & 2294 & 456 & 329.18 & 329.18 & 0.00 & 8.37 & 11.12 & 21.60 & 31.32 & 1.9275 \\
\hline PG1A-3 & 1.05 & 10.53 & 2293 & 247 & 328.09 & 328.09 & 0.00 & 8.44 & 11.16 & 20.82 & 31.27 & 2.0818 \\
\hline PG2A-1 & 1.13 & 11.32 & 2296 & 420 & 329.20 & 329.20 & 0.00 & 8.30 & 11.14 & 21.36 & 31.09 & 1.9521 \\
\hline PG2A-2 & 1.19 & 11.90 & 2300 & 522 & 327.09 & 327.09 & 0.00 & 8.38 & 11.18 & 21.94 & 31.13 & 1.8541 \\
\hline PG2A-3 & 1.16 & 11.61 & 2298 & 163 & 326.32 & 326.32 & 0.00 & 8.37 & 11.15 & 21.53 & 31.19 & 1.9306 \\
\hline PG4A-1 & 1.20 & 12.02 & 2296 & 750 & 327.81 & 327.81 & 0.00 & 8.39 & 11.11 & 22.28 & 31.15 & 1.7941 \\
\hline PG4A-2 & 1.08 & 10.85 & 2289 & 819 & 323.48 & 323.48 & 0.00 & 8.45 & 11.14 & 21.01 & 31.54 & 2.0669 \\
\hline PG4A-3 & 1.17 & 11.73 & 2294 & 726 & 334.12 & 334.12 & 0.00 & 8.37 & 11.18 & 21.92 & 31.69 & 1.9097 \\
\hline PG5A-1 & 1.13 & 11.32 & 2296 & 910 & 326.89 & 326.89 & 0.00 & 8.43 & 11.17 & 21.45 & 30.42 & 1.8726 \\
\hline PG5A-2 & 1.14 & 11.42 & 2296 & 743 & 324.40 & 324.40 & 0.00 & 8.41 & 11.16 & 21.61 & 31.10 & 1.9081 \\
\hline PG5A-3 & 1.22 & 12.24 & 2292 & 734 & 333.06 & 333.06 & 0.00 & 8.43 & 11.17 & 22.30 & 30.99 & 1.7808 \\
\hline PLRM-1 & 1.00 & 10.00 & 2000 & 755 & 321.80 & 321.80 & 0.00 & 10.48 & 11.17 & 20.26 & 30.97 & 2.1782 \\
\hline PLRM-2 & 1.06 & 10.62 & 1996 & 44 & 335.82 & 335.82 & 0.00 & 10.47 & 11.11 & 20.73 & 31.06 & 2.0738 \\
\hline PLRM-3 & 1.04 & 10.42 & 1996 & 904 & 324.32 & 324.31 & -0.01 & 10.47 & 11.14 & 20.70 & 31.36 & 2.1151 \\
\hline PBL-1 & 0.00 & 12.11 & & 553 & 324.70 & 324.70 & 0.00 & Not measured & 11.15 & 22.79 & 22.84 & 1.0043 \\
\hline BBL-2 & 0.00 & 12.15 & & 558 & 325.86 & 325.87 & 0.01 & Not measured & 11.17 & 23.09 & 23.16 & 1.0059 \\
\hline
\end{tabular}


Table 18. Results of 7-day PCTs with salt-loaded CWF materials

\begin{tabular}{|c|c|c|c|c|c|c|c|c|c|c|}
\hline & $\mathrm{Al}, \mathrm{mg} / \mathrm{L}$ & $\mathrm{B}, \mathrm{mg} / \mathrm{L}$ & $N C(\mathrm{~B}), \mathrm{g} / \mathrm{L}$ & $N L(B), g / m^{2}$ & $\mathrm{Na}, \mathrm{mg} / \mathrm{L}$ & $N C(\mathrm{Na}), \mathrm{g} / \mathrm{L}$ & $N L(\mathrm{Na}), \mathrm{g} / \mathrm{m}^{2}$ & $\mathrm{Si}, \mathrm{mg} / \mathrm{L}$ & $N C(\mathrm{Si}), \mathrm{g} / \mathrm{L}$ & $N L(\mathrm{Si}), \mathrm{g} / \mathrm{m}^{2}$ \\
\hline PS1A-1 & 33.64 & 8.87 & 0.645 & 0.280 & 36.8 & 0.283 & 0.123 & 42.4 & 0.209 & 0.0909 \\
\hline PS1A-2 & 34.30 & 9.11 & 0.662 & 0.288 & 37.5 & 0.289 & 0.125 & 43.1 & 0.213 & 0.0926 \\
\hline PS1A-3 & 34.23 & 10.31 & 0.750 & 0.326 & 37.5 & 0.289 & 0.126 & 43.5 & 0.215 & 0.0935 \\
\hline PS1A-avg & & & 0.685 & 0.298 & & 0.287 & 0.125 & & 0.212 & 0.0923 \\
\hline PS2C-1 & 30.66 & 2.91 & 0.201 & 0.087 & 30.1 & 0.235 & 0.102 & 40.7 & 0.199 & 0.0866 \\
\hline PS2C-2 & 30.72 & 2.74 & 0.190 & 0.082 & 28.8 & 0.225 & 0.098 & 40.1 & 0.196 & 0.0853 \\
\hline PS2C-3 & 31.59 & 2.34 & 0.162 & 0.070 & 30.5 & 0.238 & 0.103 & 40.9 & 0.200 & 0.0870 \\
\hline PS2C-avg & & & 0.184 & 0.080 & & 0.233 & 0.101 & & 0.199 & 0.0863 \\
\hline PS3A-1 & 26.74 & 2.01 & 0.140 & 0.061 & 29.9 & 0.243 & 0.106 & 35.3 & 0.179 & 0.0778 \\
\hline PS3A-2 & 27.68 & 1.99 & 0.138 & 0.060 & 31.1 & 0.253 & 0.110 & 36.2 & 0.183 & 0.0799 \\
\hline PS3A-3 & 26.66 & 1.76 & 0.122 & 0.053 & 30.2 & 0.246 & 0.107 & 33.8 & 0.172 & 0.0748 \\
\hline PS3A-avg & & & 0.133 & 0.058 & & 0.248 & 0.108 & & 0.178 & 0.0775 \\
\hline PS3C-1 & 25.28 & 1.98 & 0.136 & 0.059 & 33.2 & 0.265 & 0.116 & 34.4 & 0.172 & 0.0750 \\
\hline PS3C-2 & 26.21 & 1.87 & 0.128 & 0.056 & 31.9 & 0.256 & 0.111 & 34.5 & 0.173 & 0.0754 \\
\hline PS3C-3 & 27.56 & 1.90 & 0.130 & 0.056 & 32.1 & 0.257 & 0.112 & 35.8 & 0.179 & 0.0781 \\
\hline PS3C-avg & & & 0.131 & 0.057 & & 0.259 & 0.113 & & 0.175 & 0.0762 \\
\hline PS3E-1 & 22.51 & 2.16 & 0.148 & 0.064 & 34.2 & 0.308 & 0.134 & 32.8 & 0.171 & 0.0742 \\
\hline PS3E-2 & 23.24 & 2.10 & 0.144 & 0.063 & 33.6 & 0.303 & 0.132 & 33.0 & 0.172 & 0.0749 \\
\hline PS3E-3 & 24.32 & 2.11 & 0.145 & 0.063 & 36.0 & 0.324 & 0.141 & 33.3 & 0.174 & 0.0755 \\
\hline PS3E-avg & & & 0.146 & 0.063 & & 0.312 & 0.136 & & 0.172 & 0.0749 \\
\hline PS4A-1 & 16.30 & 1.87 & 0.122 & 0.053 & 36.1 & 0.290 & 0.126 & 23.8 & 0.117 & 0.0509 \\
\hline PS4A-2 & 18.05 & 1.98 & 0.129 & 0.056 & 39.1 & 0.314 & 0.137 & 25.6 & 0.126 & 0.0549 \\
\hline PS4A-3 & 18.98 & 1.87 & 0.122 & 0.053 & 41.3 & 0.332 & 0.145 & 26.3 & 0.130 & 0.0565 \\
\hline PS4A-avg & & & 0.124 & 0.054 & & 0.312 & 0.136 & & 0.124 & 0.0541 \\
\hline PS5B-1 & 19.03 & 2.72 & 0.185 & 0.081 & 46.1 & 0.398 & 0.173 & 25.7 & 0.127 & 0.0551 \\
\hline PS5B-2 & 18.17 & 2.40 & 0.164 & 0.071 & 43.3 & 0.373 & 0.163 & 25.8 & 0.127 & 0.0553 \\
\hline PS5B-3 & 17.94 & 2.27 & 0.155 & 0.067 & 42.2 & 0.364 & 0.158 & 24.0 & 0.118 & 0.0514 \\
\hline PS5B-avg & & & 0.168 & 0.073 & & 0.378 & 0.165 & & 0.124 & 0.0539 \\
\hline PG1A-1 & 19.13 & 1.83 & 0.155 & 0.067 & 48.5 & 0.384 & 0.167 & 23.6 & 0.119 & 0.0518 \\
\hline PG1A-2 & 18.89 & 1.90 & 0.160 & 0.070 & 48.2 & 0.382 & 0.166 & 23.3 & 0.118 & 0.0513 \\
\hline PG1A-3 & 20.07 & 1.89 & 0.159 & 0.069 & 48.3 & 0.382 & 0.167 & 22.7 & 0.114 & 0.0499 \\
\hline PG1A-avg & & & 0.158 & 0.069 & & 0.383 & 0.167 & & 0.117 & 0.0510 \\
\hline PG2A-1 & 17.61 & 2.17 & 0.165 & 0.072 & 46.7 & 0.361 & 0.157 & 23.8 & 0.121 & 0.0529 \\
\hline PG2A-2 & 18.47 & 2.08 & 0.158 & 0.069 & 43.0 & 0.333 & 0.145 & 24.5 & 0.125 & 0.0542 \\
\hline PG2A-3 & 18.50 & 2.12 & 0.162 & 0.070 & 42.7 & 0.330 & 0.144 & 24.7 & 0.126 & 0.0548 \\
\hline$P G 2 A-a v g$ & & & 0.162 & 0.070 & & 0.341 & 0.149 & & 0.124 & 0.0540 \\
\hline
\end{tabular}


Table 18. (continued)

\begin{tabular}{|c|c|c|c|c|c|c|c|c|c|c|}
\hline & $\mathrm{Al}, \mathrm{mg} / \mathrm{L}$ & $\mathrm{B}, \mathrm{mg} / \mathrm{L}$ & $N C(\mathrm{~B}), \mathrm{g} / \mathrm{L}$ & $N L(\mathrm{~B}), \mathrm{g} / \mathrm{m}^{2}$ & $\mathrm{Na}, \mathrm{mg} / \mathrm{L}$ & $N C(\mathrm{Na}), \mathrm{g} / \mathrm{L}$ & $N L(\mathrm{Na}), \mathrm{g} / \mathrm{m}^{2}$ & $\mathrm{Si}, \mathrm{mg} / \mathrm{L}$ & $N C(\mathrm{Si}), \mathrm{g} / \mathrm{L}$ & $N L(\mathrm{Si}), \mathrm{g} / \mathrm{m}^{2}$ \\
\hline PG4A-1 & 22.43 & 2.06 & 0.123 & 0.054 & 29.6 & 0.240 & 0.105 & 30.7 & 0.141 & 0.0614 \\
\hline PG4A-2 & 23.56 & 2.03 & 0.121 & 0.053 & 41.3 & 0.336 & 0.147 & 31.4 & 0.144 & 0.0631 \\
\hline PG4A-3 & 22.53 & 2.01 & 0.120 & 0.052 & 27.7 & 0.225 & 0.098 & 30.7 & 0.141 & 0.0616 \\
\hline PG4A-avg & & & 0.121 & 0.053 & & 0.267 & 0.116 & & 0.142 & 0.0621 \\
\hline PG5A-1 & 24.34 & 2.42 & 0.138 & 0.060 & 32.4 & 0.276 & 0.120 & 33.0 & 0.159 & 0.0691 \\
\hline PG5A-2 & 23.09 & 2.40 & 0.138 & 0.060 & 30.7 & 0.262 & 0.114 & 31.7 & 0.153 & 0.0664 \\
\hline PG5A-3 & 23.51 & 2.42 & 0.139 & 0.060 & 30.6 & 0.261 & 0.114 & 32.2 & 0.155 & 0.0677 \\
\hline PG5A-avg & & & 0.138 & 0.060 & & 0.266 & 0.116 & & 0.156 & 0.0678 \\
\hline PLRM-1 & 11.41 & 18.21 & 0.797 & 0.399 & 103.5 & 0.715 & 0.357 & 63.6 & 0.280 & 0.0909 \\
\hline PLRM-2 & 11.65 & 19.64 & 0.860 & 0.431 & 109.5 & 0.756 & 0.379 & 64.7 & 0.284 & 0.0926 \\
\hline PLRM-3 & 12.42 & 20.05 & 0.878 & 0.440 & 112.1 & 0.774 & 0.388 & 66.6 & 0.293 & 0.0935 \\
\hline PLRM-avg & 11.83 & 19.30 & 0.845 & 0.423 & 108.4 & 0.749 & 0.375 & 65.0 & 0.286 & 0.0923 \\
\hline PBL-1 & 0.02 & 0.0865 & & & 0.0045 & & & 0.138 & & \\
\hline PBL-2 & 0.01 & 0.0127 & & & 0.0045 & & & 0.138 & & \\
\hline
\end{tabular}


Table 19. Results of XRD analyses of long-term heat-treated CWF materials heated at $400{ }^{\circ} \mathrm{C}$

\begin{tabular}{|c|c|c|c|c|c|c|c|c|c|c|c|c|c|c|}
\hline \multicolumn{4}{|c|}{$400^{\circ} \mathrm{C} \quad 1$ week } & \multicolumn{4}{|c|}{$400^{\circ} \mathrm{C} 2$ weeks } & \multicolumn{4}{|c|}{$400^{\circ} \mathrm{C} 3$ months } & \multicolumn{3}{|c|}{ Reference phases } \\
\hline \multirow[t]{11}{*}{$d(\AA)$} & $\begin{array}{l}\text { Peak } \\
\text { shift }\end{array}$ & $\begin{array}{c}1 \% \text { peak } \\
\text { area }\end{array}$ & $\begin{array}{c}1 \% \text { peak } \\
\text { height }\end{array}$ & $d(\AA)$ & $\begin{array}{l}\text { Peak } \\
\text { shift }\end{array}$ & $\begin{array}{c}1 \% \text { peak } \\
\text { area }\end{array}$ & $\begin{array}{c}\text { I\% peak } \\
\text { height }\end{array}$ & $d(\AA)$ & $\begin{array}{c}\text { Peak } \\
\text { shift }\end{array}$ & $\begin{array}{c}1 \% \text { peak } \\
\text { area }\end{array}$ & $\begin{array}{c}1 \% \text { peak } \\
\text { height }\end{array}$ & Phase & $d(\AA)$ & $\begin{array}{c}\text { I\% peak } \\
\text { height }\end{array}$ \\
\hline & & & & 8.6051 & & 0.3 & 2.9 & & & & & & 8.57 & \\
\hline & & & & & & & & & & & & & 7.71 & \\
\hline & & & & 7.2222 & & 0.2 & 2.8 & & & & & & 7.19 & \\
\hline & & & & & & & & 7.0343 & & 0.3 & 2.3 & & 7.01 & \\
\hline & & & & & & & & 6.9857 & & 0.3 & 2.2 & & 6.98 & \\
\hline & & & & & & & & 6.8711 & & 0.2 & 2 & & 6.85 & \\
\hline & & & & 6.5957 & & 0.5 & 2.9 & 6.535 & & 1.3 & 2.6 & & 6.56 & \\
\hline & & & & 6.5451 & & 1.1 & 3 & & & & & & 6.52 & \\
\hline & & & & 6.511 & & 2.1 & 3.4 & & & & & & 6.48 & \\
\hline & & & & & & & & 6.3277 & & 24.4 & 21.2 & & 6.31 & \\
\hline \multirow[t]{10}{*}{6.3491} & -0.069 & 26.1 & 25.9 & 6.312 & -0.032 & 26.1 & 25.2 & 6.3033 & -0.023 & 27.4 & 26.4 & Sodalite & 6.28 & 40 \\
\hline & & & & 5.4347 & & 0.9 & 3.6 & & & & & & 5.81 & \\
\hline & & & & 5.2327 & & 0.5 & 3.6 & & & & & & 5.64 & \\
\hline & & & & & & & & & & & & & 5.40 & \\
\hline & & & & & & & & & & & & & 5.20 & \\
\hline & & & & & & & & & & & & Nepheline & 5.0058 & 10 \\
\hline & & & & 4.8082 & & 0.4 & 4.2 & & & & & & 4.81 & \\
\hline & & & & 4.7311 & & 0.3 & 4.2 & & & & & & 4.73 & \\
\hline & & & & & & & & 4.5231 & & 1.1 & 3.5 & & 4.51 & \\
\hline & & & & 4.4884 & & 3.2 & 6.5 & & & & & & 4.49 & \\
\hline \multirow[t]{8}{*}{4.4705} & -0.031 & 7 & 7.5 & 4.4414 & -0.001 & 6.5 & 9.7 & 4.4494 & -0.009 & 8 & 9.3 & Sodalite & 4.44 & 5 \\
\hline & & & & & & & & & & & & Nepheline & 4.3335 & 35 \\
\hline & & & & & & & & 4.3019 & & 0.5 & 3.7 & & 4.30 & \\
\hline & & & & & & & & 4.2882 & & 0.5 & 3.9 & & 4.29 & \\
\hline & & & & & & & & 4.2185 & & 0.7 & 3.9 & & 4.22 & \\
\hline & & & & & & & & & & & & Nepheline & 4.1766 & 80 \\
\hline & & & & & & & & 4.1478 & & 1.1 & 3.9 & & 4.15 & \\
\hline & & & & & & & & 4.0081 & & 1 & 4.3 & & 4.01 & \\
\hline \multirow[t]{6}{*}{3.9921} & -0.022 & 1.2 & 1.4 & 3.7918 & 0.178 & 0.3 & 5.4 & 3.9698 & 0.000 & 1 & 4.3 & Sodalite & 3.97 & 1 \\
\hline & & & & & & & & 3.8977 & & 0.5 & 4.2 & & 3.89 & \\
\hline & & & & & & & & & & & & Nepheline & 3.8438 & 100 \\
\hline & & & & & & & & 3.795 & & 0.6 & 4.1 & & 3.79 & \\
\hline & & & & & & & & & & & & Nepheline & 3.7614 & 2 \\
\hline & & & & 3.7005 & & 1 & 6 & & & & & & 3.70 & \\
\hline \multirow[t]{3}{*}{3.6444} & -0.020 & 100 & 100 & 3.6304 & -0.006 & 100 & 100 & 3.6305 & -0.006 & 100 & 100 & Sodalite & 3.624 & 100 \\
\hline & & & & & & & & 3.5788 & & 1.6 & 4.7 & & 3.57 & \\
\hline & & & & 3.3138 & & 1 & 5 & & & & & & 3.31 & \\
\hline
\end{tabular}


Table 19. (continued)

\begin{tabular}{|c|c|c|c|c|c|c|c|c|c|c|c|c|c|c|}
\hline \multicolumn{4}{|c|}{$400^{\circ} \mathrm{C} 1$ week } & \multicolumn{4}{|c|}{$400^{\circ} \mathrm{C} 4$ weeks } & \multicolumn{4}{|c|}{$400^{\circ} \mathrm{C} 3$ months } & \multicolumn{3}{|c|}{ Reference phases } \\
\hline \multirow[t]{13}{*}{$d(\AA)$} & $\begin{array}{l}\text { Peak } \\
\text { shift }\end{array}$ & $\begin{array}{c}\text { I\% peak } \\
\text { area }\end{array}$ & $\begin{array}{c}\text { I\% peak } \\
\text { height }\end{array}$ & $d(\AA \AA)$ & $\begin{array}{c}\text { Peak } \\
\text { shift }\end{array}$ & $\begin{array}{c}1 \% \text { peak } \\
\text { area }\end{array}$ & $\begin{array}{c}\text { I\% peak } \\
\text { height }\end{array}$ & $d(\AA)$ & $\begin{array}{c}\text { Peak } \\
\text { shift }\end{array}$ & $\begin{array}{c}\text { I\% peak } \\
\text { area }\end{array}$ & $\begin{array}{c}\text { I\% peak } \\
\text { height }\end{array}$ & Phase & $d(\AA \AA)$ & $\begin{array}{c}1 \% \text { peak } \\
\text { height }\end{array}$ \\
\hline & & & & 3.279 & & 1.5 & 5.4 & & & & & Nepheline & 3.2731 & 70 \\
\hline & & & & & & & & & & & & Halite & 3.26 & 13 \\
\hline & & & & & & & & & & & & & 3.24 & \\
\hline & & & & & & & & 3.1687 & & 0.2 & 3.7 & & 3.17 & \\
\hline & & & & 3.105 & & 0.5 & 4.8 & & & & & & 3.11 & \\
\hline & & & & 3.0633 & & 0.4 & 4.7 & & & & & & 3.06 & \\
\hline & & & & 3.0461 & & 0.3 & 4.5 & & & & & Nepheline & 3.0461 & 18 \\
\hline & & & & & & & & & & & & Nepheline & 3.0059 & 100 \\
\hline & & & & & & & & & & & & Nepheline & 2.8864 & 35 \\
\hline & & & & 2.8592 & & 0.3 & 4.1 & & & & & & 2.86 & \\
\hline & & & & 2.8375 & & 10.3 & 6.4 & 2.8357 & & 3.4 & 4.9 & & 2.84 & \\
\hline & & & & 2.8306 & & 14.7 & 7.8 & 2.8254 & & 5.9 & 5.8 & Halite & 2.821 & 100 \\
\hline \multirow[t]{5}{*}{2.817} & -0.010 & 11.7 & 8.8 & 2.8099 & -0.003 & 13.2 & 12 & 2.8098 & -0.003 & 12.6 & 9.5 & Sodalite & 2.807 & 8 \\
\hline & & & & & & & & & & & & & 2.76 & \\
\hline & & & & & & & & 2.7142 & & 0.4 & 2.7 & & 2.71 & \\
\hline & & & & & & & & & & & & & 2.66 & \\
\hline & & & & 2.5876 & & 0.4 & 3.3 & 2.5932 & & 0.6 & 2.4 & & 2.59 & \\
\hline \multirow[t]{3}{*}{2.5694} & -0.006 & 19.1 & 18 & 2.5644 & -0.001 & 20.9 & 23.5 & 2.5632 & 0.000 & 19.6 & 18.4 & Sodalite & 2.563 & 16 \\
\hline & & & & & & & & 2.5367 & & 1 & 2.3 & Nepheline & 2.50 & 14 \\
\hline & & & & & & & & 2.3928 & & 0.9 & 2.2 & & 2.39 & \\
\hline \multirow[t]{6}{*}{2.3782} & -0.005 & 23.0 & 21.5 & 2.3721 & 0.001 & 22.3 & 24 & 2.3732 & 0.000 & 20.2 & 18.6 & Sodalite & 2.373 & 16 \\
\hline & & & & 2.3482 & & 1.0 & 2.7 & 2.3516 & & 1.2 & 2.2 & & 2.35 & \\
\hline & & & & & & & & & & & & Nepheline & 2.3395 & 35 \\
\hline & & & & & & & & & & & & Nepheline & 2.3074 & 25 \\
\hline & & & & 2.2538 & & 0.4 & 2.3 & 2.2746 & & 0.2 & 2 & & 2.27 & \\
\hline & & & & 2.2325 & & 0.7 & 2.5 & 2.2287 & & 0.8 & 2 & & 2.23 & \\
\hline \multirow[t]{4}{*}{2.2248} & -0.006 & 2.0 & 1.7 & 2.221 & -0.002 & 1.6 & 3.2 & 2.2221 & -0.003 & 1.6 & 2.8 & Sodalite & 2.219 & 1 \\
\hline & & & & 2.2106 & & 2.2 & 2.6 & & & & & Nepheline & 2.163 & 5 \\
\hline & & & & 2.205 & & 0.8 & 2.5 & & & & & Nepheline & 2.1188 & 7 \\
\hline & & & & & & & & & & & & Nepheline & 2.0938 & 5 \\
\hline \multirow[t]{3}{*}{2.0952} & -0.002 & 40.0 & 35.6 & 2.0924 & 0.001 & 32.9 & 33.6 & 2.0933 & 0.000 & 30.5 & 26.7 & Sodalite & 2.093 & 20 \\
\hline & & & & & & & & & & & & & 2.09 & \\
\hline & & & & & & & & & & & & & 2.07 & \\
\hline 2.0039 & & 4.3 & 2.5 & 1.9995 & & 5.0 & 4.3 & 1.9994 & & 4.1 & 3.4 & Halite & 1.994 & 55 \\
\hline \multirow[t]{3}{*}{1.9892} & -0.004 & 8.7 & 4.8 & 1.9852 & 0.000 & 7.8 & 6.7 & 1.9853 & 0.000 & 6.7 & 5.3 & Sodalite & 1.985 & 3 \\
\hline & & & & & & & & & & & & Nepheline & 1.9313 & 6 \\
\hline & & & & 1.9043 & & 0.5 & 2.5 & & & & & & 1.90 & \\
\hline
\end{tabular}


Table 19. (continued)

\begin{tabular}{|c|c|c|c|c|c|c|c|c|c|c|c|c|c|c|}
\hline \multicolumn{4}{|c|}{$400^{\circ} \mathrm{C} 1$ week } & \multicolumn{4}{|c|}{$400^{\circ} \mathrm{C} 2$ weeks } & \multicolumn{4}{|c|}{$400^{\circ} \mathrm{C} 3$ months } & \multicolumn{3}{|c|}{ Reference phases } \\
\hline$d(\AA)$ & $\begin{array}{c}\text { Peak } \\
\text { shift }\end{array}$ & $\begin{array}{c}\% \text { peak } \\
\text { area } \\
\end{array}$ & $\begin{array}{c}1 \% \text { peak } \\
\text { height }\end{array}$ & $d(\AA)$ & $\begin{array}{c}\text { Peak } \\
\text { shift }\end{array}$ & $\begin{array}{c}1 \% \text { peak } \\
\text { area }\end{array}$ & $\begin{array}{c}1 \% \text { peak } \\
\text { height }\end{array}$ & $d(\AA)$ & $\begin{array}{l}\text { Peak } \\
\text { shift }\end{array}$ & $\begin{array}{c}\% \text { peak } \\
\text { area }\end{array}$ & $\begin{array}{c}1 \% \text { peak } \\
\text { height }\end{array}$ & Phase & $d(\AA)$ & $\begin{array}{c}1 \% \text { peak } \\
\text { height }\end{array}$ \\
\hline \multirow[t]{4}{*}{1.8943} & -0.001 & 4.9 & 4.2 & 1.8923 & 0.001 & 4.5 & 5.8 & 1.8916 & 0.001 & 4.1 & 4.8 & Sodalite & 1.893 & 3 \\
\hline & & & & 1.8887 & & 4.4 & 4.5 & & & & & & 1.89 & \\
\hline & & & & & & & & & & & & Nepheline & 1.8411 & 2 \\
\hline & & & & & & & & 1.8189 & & 0.3 & 1.8 & & 1.82 & \\
\hline \multirow[t]{5}{*}{1.814} & -0.002 & 4.5 & 3.7 & 1.8111 & 0.001 & 3.8 & 4.9 & 1.8124 & 0.000 & 3.1 & 4.2 & Sodalite & 1.8122 & 2 \\
\hline & & & & & & & & & & & & & 1.81 & \\
\hline & & & & & & & & & & & & & 1.80 & \\
\hline & & & & & & & & 1.8066 & & 1 & 2.6 & Nepheline & 1.7923 & 5 \\
\hline & & & & 1.7432 & & 1.6 & 3.7 & & & & & & 1.74 & \\
\hline \multirow[t]{4}{*}{1.742} & -0.001 & 4.3 & 4.2 & 1.7409 & 0.000 & 3.9 & 5.3 & 1.7414 & 0.000 & 3.9 & 4.2 & Sodalite & 1.7413 & 2 \\
\hline & & & & & & & & 1.7362 & & 3.4 & 2.9 & & 1.74 & \\
\hline & & & & & & & & & & & & Nepheline & 1.6942 & 5 \\
\hline & & & & 1.6342 & & 1.6 & 2.3 & & & & & & 1.68 & \\
\hline \multirow[t]{3}{*}{1.6338} & & 1.6 & 0.9 & 1.6308 & & 1.9 & 2.2 & 1.6317 & & 1.6 & 1.9 & Nepheline & 1.6346 & 6 \\
\hline & & & & 1.6247 & & 1.6 & 2.8 & & & & & Halite & 1.628 & 15 \\
\hline & & & & & & & & & & & & & 1.62 & \\
\hline \multirow[t]{3}{*}{1.621} & 0.000 & 4.9 & 3 & 1.6205 & 0.000 & 3.3 & 4.5 & 1.621 & 0.000 & 3.8 & 3.9 & Sodalite & 1.621 & 2 \\
\hline & & & & & & & & 1.615 & & 2.5 & 2.4 & Nepheline & 1.615 & 8 \\
\hline & & & & 1.5862 & & 0.2 & 2.2 & & & & & Nepheline & 1.6002 & 4 \\
\hline \multirow[t]{2}{*}{1.5702} & -0.001 & 14.3 & 11.8 & 1.5682 & 0.001 & 12.4 & 12.2 & 1.569 & 0.001 & 12.9 & 10 & Sodalite & 1.5696 & 5 \\
\hline & & & & 1.5653 & & 9.2 & 7.7 & & & & & Nepheline & 1.5614 & 14 \\
\hline 1.5232 & -0.001 & 7.6 & 5.8 & 1.5225 & 0.000 & 6.6 & 6.8 & 1.5214 & 0.001 & 6.3 & 6 & Sodalite & 1.5227 & 3 \\
\hline \multirow[t]{4}{*}{1.4797} & 0.000 & 11.9 & 8.9 & 1.4788 & 0.001 & 10 & 9.8 & 1.4785 & 0.001 & 10.1 & 7.7 & Sodalite & 1.4797 & 4 \\
\hline & & & & & & & & 1.4755 & & 5.8 & 5.6 & & 1.47 & \\
\hline & & & & & & & & & & & & Nepheline & 1.4687 & 5 \\
\hline & & & & & & & & & & & & Nepheline & 1.4555 & 3 \\
\hline \multirow[t]{4}{*}{1.4405} & 0.000 & 12.5 & 9.2 & 1.4388 & 0.002 & 10.9 & 10.2 & 1.4392 & 0.001 & 10.2 & 8.2 & Sodalite & 1.4404 & 5 \\
\hline & & & & 1.4325 & & 1.1 & 2.5 & & & & & & 1.43 & \\
\hline & & & & & & & & & & & & Nepheline & 1.4282 & 7 \\
\hline & & & & 1.4098 & & 0.3 & 2.2 & & & & & Halite & 1.41 & 6 \\
\hline \multirow[t]{3}{*}{1.4035} & 0.000 & 0.5 & 0.8 & 1.4028 & 0.001 & 0.4 & 2.7 & 1.4023 & 0.001 & 1.4 & 1.9 & Sodalite & 1.4038 & 1 \\
\hline & & & & 1.4005 & & 0.2 & 2.3 & 1.3987 & & 1.4 & 1.6 & & 1.40 & \\
\hline & & & & & & & & 1.3722 & & 1.4 & 1.9 & Nepheline & 1.3865 & 6 \\
\hline 1.3697 & 0.000 & 5.1 & 3.8 & 1.369 & 0.001 & 4.7 & 5 & 1.369 & 0.001 & 4.7 & 4.1 & Sodalite & 1.3699 & 2 \\
\hline
\end{tabular}


Table 19. (continued)

\begin{tabular}{|c|c|c|c|c|c|c|c|c|c|c|c|c|c|c|}
\hline \multicolumn{4}{|c|}{$400^{\circ} \mathrm{C} \quad 1$ week } & \multicolumn{4}{|c|}{$400^{\circ} \mathrm{C} 2$ weeks } & \multicolumn{4}{|c|}{$400^{\circ} \mathrm{C} 3$ months } & \multicolumn{3}{|c|}{ Reference phases } \\
\hline \multirow[t]{2}{*}{$d(\AA)$} & $\begin{array}{l}\text { Peak } \\
\text { shift }\end{array}$ & $\begin{array}{c}1 \% \text { peak } \\
\text { area }\end{array}$ & $\begin{array}{c}\text { I\% peak } \\
\text { height }\end{array}$ & $d(\AA)$ & $\begin{array}{l}\text { Peak } \\
\text { shift }\end{array}$ & $\begin{array}{c}\text { I\% peak } \\
\text { area }\end{array}$ & $\begin{array}{c}1 \% \text { peak } \\
\text { height }\end{array}$ & $d(\AA)$ & $\begin{array}{c}\text { Peak } \\
\text { shift }\end{array}$ & $\begin{array}{c}1 \% \text { peak } \\
\text { area }\end{array}$ & $\begin{array}{c}1 \% \text { peak } \\
\text { height }\end{array}$ & Phase & $d(\AA)$ & $\begin{array}{c}1 \% \text { peak } \\
\text { height }\end{array}$ \\
\hline & & & & & & & & 1.3665 & & 3.9 & 2.9 & & 1.37 & \\
\hline \multirow[t]{2}{*}{1.3387} & 0.000 & 5.7 & 4 & 1.3369 & 0.002 & 4.6 & 4.9 & 1.3373 & 0.001 & 3.8 & 4.2 & Sodalite & 1.3385 & 2 \\
\hline & & & & 1.3293 & & 0.1 & 2 & & & & & & 1.33 & \\
\hline \multirow[t]{2}{*}{1.3088} & 0.000 & 5.1 & 3.9 & 1.3082 & 0.001 & 4.7 & 4.2 & 1.3079 & 0.001 & 4.4 & 4.4 & Sodalite & 1.3091 & 2 \\
\hline & & & & 1.3074 & & 5.1 & 5.2 & 1.3059 & & 5.4 & 2.9 & & 1.30 & \\
\hline \multirow[t]{2}{*}{1.2813} & 0.000 & 3.5 & 2.6 & 1.2799 & 0.002 & 3.3 & 4 & 1.2802 & 0.001 & 2.9 & 3.1 & Sodalite & 1.2814 & 2 \\
\hline & & & & 1.7432 & & 1.6 & 3.7 & 1.8066 & & 1 & 2.6 & Nepheline & 1.279 & 6 \\
\hline
\end{tabular}


Table 19. (continued)

\begin{tabular}{|c|c|c|c|c|c|c|c|c|c|c|}
\hline \multicolumn{4}{|c|}{$400^{\circ} \mathrm{C} 6$ months } & \multicolumn{4}{|c|}{$400^{\circ} \mathrm{C} 1$ year } & \multicolumn{3}{|c|}{ Reference phases } \\
\hline \multirow[t]{11}{*}{$d(\AA)$} & $\begin{array}{c}\text { Peak } \\
\text { shift }\end{array}$ & $\begin{array}{c}1 \% \text { peak } \\
\text { area }\end{array}$ & $\begin{array}{c}1 \% \text { peak } \\
\text { height }\end{array}$ & $d(\AA)$ & $\begin{array}{l}\text { Peak } \\
\text { shift }\end{array}$ & $\begin{array}{c}1 \% \text { peak } \\
\text { area }\end{array}$ & $\begin{array}{c}1 \% \text { peak } \\
\text { height }\end{array}$ & Phase & $d(\mathrm{~A})$ & $\begin{array}{c}\% \text { peak } \\
\text { height }\end{array}$ \\
\hline & & & & & & & & & 8.57 & \\
\hline & & & & & & & & & 7.71 & \\
\hline & & & & & & & & & 7.19 & \\
\hline & & & & & & & & & 7.01 & \\
\hline & & & & & & & & & 6.98 & \\
\hline & & & & & & & & & 6.85 & \\
\hline & & & & & & & & & 6.56 & \\
\hline & & & & & & & & & 6.52 & \\
\hline & & & & & & & & & 6.48 & \\
\hline & & & & & & & & & 6.31 & \\
\hline \multirow[t]{10}{*}{6.2864} & -0.006 & 25.8 & 23.9 & 6.3694 & -0.089 & 29.8 & 29.2 & Sodalite & 6.28 & 40 \\
\hline & & & & & & & & & 5.81 & \\
\hline & & & & & & & & & 5.64 & \\
\hline & & & & & & & & & 5.40 & \\
\hline & & & & & & & & & 5.20 & \\
\hline & & & & & & & & Nepheline & 5.0058 & 10 \\
\hline & & & & & & & & & 4.79 & \\
\hline & & & & & & & & & 4.71 & \\
\hline & & & & & & & & & 4.52 & \\
\hline & & & & & & & & & 4.46 & \\
\hline \multirow[t]{8}{*}{4.4394} & 0.001 & 6.5 & 6.5 & 4.4793 & -0.039 & 6.6 & 7.1 & Sodalite & 4.44 & 5 \\
\hline & & & & & & & & Nepheline & 4.3335 & 35 \\
\hline & & & & & & & & & 4.30 & \\
\hline & & & & & & & & & 4.29 & \\
\hline & & & & & & & & & 4.22 & \\
\hline & & & & & & & & Nepheline & 4.1766 & 80 \\
\hline & & & & & & & & & 4.15 & \\
\hline & & & & & & & & & 4.01 & \\
\hline \multirow[t]{6}{*}{3.972} & -0.002 & 0.5 & 0.9 & 3.9967 & -0.027 & 1.1 & 1 & Sodalite & 3.97 & 1 \\
\hline & & & & & & & & & 3.89 & \\
\hline & & & & & & & & Nepheline & 3.8438 & 100 \\
\hline & & & & & & & & & 3.79 & \\
\hline & & & & & & & & Nepheline & 3.7614 & 2 \\
\hline & & & & & & & & & 3.70 & \\
\hline \multirow[t]{3}{*}{3.6235} & 0.001 & 100 & 100 & 3.6473 & -0.023 & 100 & 100 & Sodalite & 3.624 & 100 \\
\hline & & & & & & & & & 3.57 & \\
\hline & & & & & & & & & 3.31 & \\
\hline
\end{tabular}


Table 19. (continued)

\begin{tabular}{|c|c|c|c|c|c|c|c|c|c|c|}
\hline \multicolumn{4}{|c|}{$400^{\circ} \mathrm{C} 6$ months } & \multicolumn{4}{|c|}{$400^{\circ} \mathrm{C} 1$ year } & \multicolumn{3}{|c|}{ Reference phases } \\
\hline \multirow[t]{12}{*}{$d(\AA)$} & $\begin{array}{l}\text { Peak } \\
\text { shift }\end{array}$ & $\begin{array}{c}1 \% \text { peak } \\
\text { area }\end{array}$ & $\begin{array}{c}1 \% \text { peak } \\
\text { height }\end{array}$ & $d(\AA)$ & $\begin{array}{l}\text { Peak } \\
\text { shift }\end{array}$ & $\begin{array}{c}1 \% \text { peak } \\
\text { area }\end{array}$ & $\begin{array}{c}1 \% \text { peak } \\
\text { height }\end{array}$ & Phase & $d(\mathrm{~A})$ & $\begin{array}{c}1 \% \text { peak } \\
\text { height }\end{array}$ \\
\hline & & & & & & & & Nepheline & 3.2731 & 70 \\
\hline & & & & & & & & Halite & 3.26 & 13 \\
\hline & & & & & & & & & 3.24 & \\
\hline & & & & & & & & & 3.17 & \\
\hline & & & & & & & & & 3.11 & \\
\hline & & & & & & & & & 3.06 & \\
\hline & & & & & & & & Nepheline & 3.0461 & 18 \\
\hline & & & & & & & & Nepheline & 3.0059 & 100 \\
\hline & & & & & & & & Nepheline & 2.8864 & 35 \\
\hline & & & & & & & & & 2.86 & \\
\hline & & & & & & & & & 2.84 & \\
\hline 2.8237 & & 10.3 & 3.3 & 2.8369 & & 12.4 & 4.7 & Halite & 2.821 & 100 \\
\hline \multirow[t]{5}{*}{2.8064} & 0.001 & 11.8 & 7.9 & 2.8204 & -0.013 & 14.7 & 10.2 & Sodalite & 2.807 & 8 \\
\hline & & & & & & & & & 2.76 & \\
\hline & & & & & & & & & 7.71 & \\
\hline & & & & & & & & & 2.66 & \\
\hline & & & & & & & & & 2.59 & \\
\hline \multirow[t]{3}{*}{2.5607} & 0.002 & 19.4 & 17.8 & 2.5721 & -0.009 & 26.8 & 24.6 & Sodalite & 2.563 & 16 \\
\hline & & & & & & & & Nepheline & 2.5 & 14 \\
\hline & & & & & & & & & 2.39 & \\
\hline \multirow[t]{6}{*}{2.3709} & 0.002 & 19.6 & 17 & 2.3804 & -0.007 & 25.8 & 25 & Sodalite & 2.373 & 16 \\
\hline & & & & & & & & & 2.35 & \\
\hline & & & & & & & & Nepheline & 2.3395 & 35 \\
\hline & & & & & & & & Nepheline & 2.3074 & 25 \\
\hline & & & & & & & & & 2.27 & \\
\hline & & & & & & & & & 2.23 & \\
\hline \multirow[t]{4}{*}{2.2172} & 0.002 & 1.1 & 1 & 2.2271 & -0.008 & 2.3 & 1.4 & Sodalite & 2.219 & 1 \\
\hline & & & & & & & & Nepheline & 2.163 & 5 \\
\hline & & & & & & & & Nepheline & 2.1188 & 7 \\
\hline & & & & & & & & Nepheline & 2.0938 & 5 \\
\hline \multirow[t]{3}{*}{2.09} & 0.003 & 31 & 27.6 & 2.0971 & -0.004 & 40.6 & 36.7 & Sodalite & 2.093 & 20 \\
\hline & & & & & & & & & 2.09 & \\
\hline & & & & & & & & & 2.07 & \\
\hline 1.9976 & & 3.1 & 1.6 & 2.0038 & & 4.8 & 2.5 & Halite & 1.994 & 55 \\
\hline 1.9832 & 0.002 & 6.8 & 4 & 1.9894 & -0.004 & 9.7 & 5.6 & Sodalite & 1.985 & 3 \\
\hline
\end{tabular}


Table 19. (continued)

\begin{tabular}{|c|c|c|c|c|c|c|c|c|c|c|}
\hline \multicolumn{4}{|c|}{$400^{\circ} \mathrm{C} 6$ months } & \multicolumn{4}{|c|}{$400^{\circ} \mathrm{C} 1$ year } & \multicolumn{3}{|c|}{ Reference phases } \\
\hline$d(\AA)$ & $\begin{array}{l}\text { Peak } \\
\text { shift }\end{array}$ & $\begin{array}{c}1 \% \text { peak } \\
\text { area }\end{array}$ & $\begin{array}{c}1 \% \text { peak } \\
\text { height }\end{array}$ & $d(\AA)$ & $\begin{array}{l}\text { Peak } \\
\text { shift }\end{array}$ & $\begin{array}{c}1 \% \text { peak } \\
\text { area }\end{array}$ & $\begin{array}{c}1 \% \text { peak } \\
\text { height }\end{array}$ & Phase & $d(\mathrm{~A})$ & $\begin{array}{c}1 \% \text { peak } \\
\text { height }\end{array}$ \\
\hline \multirow[t]{4}{*}{1.8902} & 0.003 & 4.3 & 3.4 & 1.8968 & -0.004 & 5.1 & 4 & Nepheline & 1.9313 & 6 \\
\hline & & & & & & & & & 1.90 & \\
\hline & & & & & & & & Sodalite & 1.893 & 3 \\
\hline & & & & & & & & & 1.89 & \\
\hline \multirow[t]{6}{*}{1.8092} & 0.003 & 3.8 & 2.9 & 1.8144 & -0.002 & 4.4 & 3.1 & Nepheline & 1.8411 & 2 \\
\hline & & & & & & & & & 1.82 & \\
\hline & & & & & & & & Sodalite & 1.8122 & 2 \\
\hline & & & & & & & & & 1.81 & \\
\hline & & & & & & & & & 1.80 & \\
\hline & & & & & & & & Nepheline & 1.7923 & 5 \\
\hline 1.7385 & 0.003 & 3.5 & 2.8 & 1.7432 & -0.002 & 5 & 4.1 & & 1.74 & \\
\hline \multirow[t]{6}{*}{1.7385} & 0.003 & 3.5 & 2.8 & 1.7432 & -0.002 & 5 & 4.1 & Sodalite & 1.7413 & 2 \\
\hline & & & & & & & & & 1.74 & \\
\hline & & & & & & & & Nepheline & 1.6942 & 5 \\
\hline & & & & & & & & & 1.68 & \\
\hline & & & & & & & & Nepheline & 1.6346 & 6 \\
\hline & & & & & & & & Halite & 1.628 & 15 \\
\hline \multirow[t]{3}{*}{1.6184} & 0.003 & 3.7 & 2.3 & 1.6223 & -0.001 & 4.7 & 3.2 & & 1.62 & \\
\hline & & & & & & & & Sodalite & 1.621 & 2 \\
\hline & & & & & & & & Nepheline & 1.615 & 8 \\
\hline \multirow[t]{2}{*}{1.5676} & 0.002 & 11.8 & 8.5 & 1.5705 & -0.001 & 15.3 & 12.7 & Nepheline & 1.6002 & 4 \\
\hline & & & & & & & & Sodalite & 1.5696 & 5 \\
\hline \multirow[t]{2}{*}{1.5207} & 0.002 & 6.2 & 4.1 & 1.5234 & -0.001 & 7.8 & 6.5 & Nepheline & 1.5614 & 14 \\
\hline & & & & & & & & Sodalite & 1.5227 & 3 \\
\hline \multirow[t]{4}{*}{1.4775} & 0.002 & 9.5 & 6.6 & 1.4805 & -0.001 & 12.1 & 9.1 & Sodalite & 1.4797 & 4 \\
\hline & & & & & & & & & 1.48 & \\
\hline & & & & & & & & Nepheline & 1.4687 & 5 \\
\hline & & & & & & & & Nepheline & 1.4555 & 3 \\
\hline \multirow[t]{4}{*}{1.4383} & 0.002 & 9.9 & 7.3 & 1.4407 & 0.000 & 13.3 & 10 & Sodalite & 1.4404 & 5 \\
\hline & & & & & & & & & 1.43 & \\
\hline & & & & & & & & Nepheline & 1.4282 & 7 \\
\hline & & & & & & & & Halite & 1.41 & 6 \\
\hline \multirow[t]{2}{*}{1.4016} & 0.002 & 0.8 & 0.5 & 1.4034 & 0.000 & 1.1 & 0.7 & Sodalite & 1.4038 & 1 \\
\hline & & & & & & & & & 1.40 & \\
\hline
\end{tabular}


Table 19. (continued)

\begin{tabular}{|c|c|c|c|c|c|c|c|c|c|c|}
\hline \multicolumn{4}{|c|}{$400^{\circ} \mathrm{C} 6$ months } & \multicolumn{4}{|c|}{$400^{\circ} \mathrm{C} 1$ year } & \multicolumn{3}{|c|}{ Reference phases } \\
\hline \multirow[t]{2}{*}{$d(\AA)$} & $\begin{array}{l}\text { Peak } \\
\text { shift }\end{array}$ & $\begin{array}{c}1 \% \text { peak } \\
\text { area }\end{array}$ & $\begin{array}{c}\text { I\% peak } \\
\text { height }\end{array}$ & $d(\AA)$ & $\begin{array}{l}\text { Peak } \\
\text { shift }\end{array}$ & $\begin{array}{c}1 \% \text { peak } \\
\text { area }\end{array}$ & $\begin{array}{c}\text { I\% peak } \\
\text { height }\end{array}$ & Phase & $d(\mathrm{~A})$ & $\begin{array}{c}\text { I\% peak } \\
\text { height }\end{array}$ \\
\hline & & & & & & & & Nepheline & 1.3865 & 6 \\
\hline \multirow[t]{2}{*}{1.3679} & 0.002 & 3.7 & 2.6 & 1.3704 & -0.001 & 5.4 & 4.1 & Sodalite & 1.3699 & 2 \\
\hline & & & & & & & & & 1.37 & \\
\hline \multirow[t]{2}{*}{1.3364} & 0.002 & 4.3 & 2.8 & 1.3387 & 0.000 & 6 & 3.9 & Sodalite & 1.3385 & 2 \\
\hline & & & & & & & & & 1.33 & \\
\hline \multirow[t]{3}{*}{1.3068} & 0.002 & 3.9 & 2.5 & 1.3094 & 0.000 & 5.5 & 4.1 & Sodalite & 1.3091 & 2 \\
\hline & & & & & & & & & 1.31 & \\
\hline & & & & & & & & Sodalite & 1.2814 & 2 \\
\hline 1.2794 & 0.002 & 2.7 & 2 & 1.2819 & 0.000 & 3.3 & 2.4 & Nepheline & 1.279 & 6 \\
\hline
\end{tabular}


Table 20. Results of XRD analyses of long-term heat-treated CWF materials heated at $500{ }^{\circ} \mathrm{C}$

\begin{tabular}{|c|c|c|c|c|c|c|c|c|c|c|c|c|c|c|}
\hline \multicolumn{4}{|c|}{$500^{\circ} \mathrm{C} 1$ week } & \multicolumn{4}{|c|}{$500^{\circ} \mathrm{C} 4$ weeks } & \multicolumn{4}{|c|}{$500^{\circ} \mathrm{C} 3$ months } & \multicolumn{3}{|c|}{ Reference phases } \\
\hline \multirow[t]{11}{*}{$d(\AA)$} & $\begin{array}{l}\text { Peak } \\
\text { shift }\end{array}$ & $\begin{array}{c}1 \% \text { peak } \\
\text { area }\end{array}$ & $\begin{array}{c}1 \% \text { peak } \\
\text { height }\end{array}$ & $d(\AA)$ & $\begin{array}{l}\text { Peak } \\
\text { shift }\end{array}$ & $\begin{array}{c}1 \% \text { peak } \\
\text { area }\end{array}$ & $\begin{array}{c}1 \% \text { peak } \\
\text { height }\end{array}$ & $d(\AA)$ & $\begin{array}{l}\text { Peak } \\
\text { shift }\end{array}$ & $\begin{array}{c}1 \% \text { peak } \\
\text { area }\end{array}$ & $\begin{array}{c}1 \% \text { peak } \\
\text { height }\end{array}$ & Phase & $d(\AA)$ & $\begin{array}{c}1 \% \text { peak } \\
\text { height }\end{array}$ \\
\hline & & & & & & & & & & & & & 8.57 & \\
\hline & & & & & & & & 7.7691 & & 0.3 & 2.4 & & 7.71 & \\
\hline & & & & 7.2025 & & 0.2 & 2 & 7.2613 & & 0.3 & 2.5 & & 7.19 & \\
\hline & & & & & & & & & & & & & 7.01 & \\
\hline & & & & & & & & & & & & & 6.98 & \\
\hline & & & & & & & & & & & & & 6.85 & \\
\hline & & & & & & & & & & & & & 6.56 & \\
\hline & & & & & & & & & & & & & 6.52 & \\
\hline & & & & & & & & & & & & & 6.48 & \\
\hline & & & & & & & & & & & & & 6.31 & \\
\hline \multirow[t]{10}{*}{6.3439} & -0.064 & 26.4 & 26.9 & 6.2331 & 0.047 & 29.1 & 24.5 & 6.3297 & -0.050 & 25.2 & 23.1 & Sodalite & 6.28 & 40 \\
\hline & & & & 5.7599 & & 0.2 & 2.3 & 5.7311 & & 1.3 & 2.9 & & 5.81 & \\
\hline & & & & 5.5877 & & 1 & 2.3 & & & & & & 5.64 & \\
\hline & & & & 5.3187 & & 0.6 & 2.5 & & & & & & 5.40 & \\
\hline & & & & & & & & & & & & & 5.20 & \\
\hline & & & & & & & & & & & & Nepheline & 5.0058 & 10 \\
\hline & & & & 4.8873 & & 0.6 & 2.9 & & & & & & 4.81 & \\
\hline & & & & 4.6189 & & 0.3 & 3.4 & & & & & & 4.73 & \\
\hline & & & & 4.5091 & & 1.1 & 3.3 & & & & & & 4.51 & \\
\hline & & & & & & & & & & & & & 4.49 & \\
\hline \multirow[t]{9}{*}{4.4687} & -0.029 & 5.9 & 6.2 & 4.4144 & 0.026 & 7.3 & 8.9 & 4.4621 & -0.022 & 7.3 & 10.3 & Sodalite & 4.44 & 5 \\
\hline & & & & & & & & 4.3699 & & 0.4 & 3.9 & & 4.35 & \\
\hline & & & & & & & & & & & & Nepheline & 4.3335 & 35 \\
\hline & & & & & & & & & & & & & 4.30 & \\
\hline & & & & & & & & & & & & & 4.29 & \\
\hline & & & & & & & & & & & & & 4.22 & \\
\hline & & & & & & & & & & & & Nepheline & 4.1766 & 80 \\
\hline & & & & & & & & & & & & & 4.15 & \\
\hline & & & & 4.0102 & & 0.6 & 4.1 & 4.0027 & & 1.1 & 5.1 & & 4.01 & \\
\hline \multirow[t]{6}{*}{3.9896} & -0.020 & 1.5 & 1.2 & 3.9584 & 0.012 & 1.9 & 4.4 & 3.9828 & -0.013 & 1.1 & 5.1 & Sodalite & 3.97 & 1 \\
\hline & & & & & & & & & & & & & 3.89 & \\
\hline & & & & & & & & & & & & Nepheline & 3.8438 & 100 \\
\hline & & & & & & & & & & & & & 3.79 & \\
\hline & & & & & & & & & & & & Nepheline & 3.7614 & 2 \\
\hline & & & & & & & & & & & & & 3.70 & \\
\hline 3.6404 & -0.016 & 100 & 100 & 3.6098 & 0.014 & 100 & 100 & 3.6389 & -0.015 & 100 & 100 & Sodalite & 3.624 & 100 \\
\hline
\end{tabular}


Table 20. (continued)

\begin{tabular}{|c|c|c|c|c|c|c|c|c|c|c|c|c|c|c|}
\hline \multicolumn{4}{|c|}{$500^{\circ} \mathrm{C} 1$ week } & \multicolumn{4}{|c|}{$500^{\circ} \mathrm{C} 4$ weeks } & \multicolumn{4}{|c|}{$500^{\circ} \mathrm{C} 3$ months } & \multicolumn{3}{|c|}{ Reference phases } \\
\hline \multirow[t]{4}{*}{$d(\AA)$} & $\begin{array}{l}\text { Peak } \\
\text { shift }\end{array}$ & $\begin{array}{c}1 \% \text { peak } \\
\text { area }\end{array}$ & $\begin{array}{c}1 \% \text { peak } \\
\text { height }\end{array}$ & $d(\AA)$ & $\begin{array}{l}\text { Peak } \\
\text { shift }\end{array}$ & $\begin{array}{c}1 \% \text { peak } \\
\text { area }\end{array}$ & $\begin{array}{c}1 \% \text { peak } \\
\text { height }\end{array}$ & $d(\AA)$ & $\begin{array}{c}\text { Peak } \\
\text { shift }\end{array}$ & $\begin{array}{c}1 \% \text { peak } \\
\text { area }\end{array}$ & $\begin{array}{c}1 \% \text { peak } \\
\text { height }\end{array}$ & Phase & $d(\mathrm{~A})$ & $\begin{array}{c}1 \% \text { peak } \\
\text { height }\end{array}$ \\
\hline & & & & 3.5537 & & 2.5 & 4.6 & & & & & & 3.57 & \\
\hline & & & & & & & & & & & & & 3.31 & \\
\hline & & & & & & & & & & & & Nepheline & 3.2731 & 70 \\
\hline \multirow[t]{11}{*}{3.2815} & & 0.8 & 1.1 & 3.2602 & & 0.8 & 4 & 3.2803 & & 0.9 & 4.8 & Halite & 3.26 & 13 \\
\hline & & & & & & & & 3.2554 & & 0.8 & 4.5 & & 3.24 & \\
\hline & & & & & & & & & & & & & 3.17 & \\
\hline & & & & & & & & & & & & & 3.11 & \\
\hline & & & & & & & & & & & & & 3.06 & \\
\hline & & & & & & & & 3.0578 & & 0.6 & 4.2 & Nepheline & 3.0461 & 18 \\
\hline & & & & & & & & 3.0273 & & 0.7 & 3.9 & Nepheline & 3.0059 & 100 \\
\hline & & & & & & & & 2.8939 & & 0.6 & 4 & Nepheline & 2.8864 & 35 \\
\hline & & & & & & & & & & & & & 2.86 & \\
\hline & & & & & & & & & & & & & 2.84 & \\
\hline & & & & 2.8184 & & 6.9 & 6.9 & 2.8341 & & 7.6 & 7.6 & Halite & 2.821 & 100 \\
\hline \multirow[t]{5}{*}{2.8159} & -0.009 & 14.6 & 11.0 & 2.7965 & 0.011 & 13.3 & 11.7 & 2.815 & -0.008 & 13.6 & 11.5 & Sodalite & 2.807 & 8 \\
\hline & & & & 2.7489 & & 0.5 & 2.9 & & & & & & 2.76 & \\
\hline & & & & & & & & & & & & & 2.71 & \\
\hline & & & & 2.6517 & & 0.2 & 2.6 & 2.7213 & & 0.6 & 3.1 & & 2.66 & \\
\hline & & & & & & & & & & & & & 2.59 & \\
\hline \multirow[t]{3}{*}{2.5686} & -0.006 & 24.8 & 23.6 & 2.5544 & 0.009 & 20.4 & 21.5 & 2.5672 & -0.004 & 20.1 & 20.9 & Sodalite & 2.563 & 16 \\
\hline & & & & & & & & 2.5434 & & 1.3 & 2.9 & Nepheline & 2.50 & 14 \\
\hline & & & & & & & & & & & & & 2.39 & \\
\hline \multirow[t]{6}{*}{2.3775} & -0.004 & 26.0 & 25.0 & 2.3657 & 0.007 & 19.9 & 21 & 2.3767 & -0.004 & 21.2 & 22.1 & Sodalite & 2.373 & 16 \\
\hline & & & & & & & & & & & & & 2.35 & \\
\hline & & & & & & & & & & & & Nepheline & 2.3395 & 35 \\
\hline & & & & & & & & & & & & Nepheline & 2.3074 & 25 \\
\hline & & & & & & & & & & & & & 2.27 & \\
\hline & & & & 2.2299 & & 0.8 & 2 & & & & & & 2.23 & \\
\hline \multirow[t]{4}{*}{2.2225} & -0.004 & 1.7 & 1.4 & 2.2136 & 0.005 & 1.3 & 2.9 & 2.2222 & -0.003 & 1.1 & 3.3 & Sodalite & 2.219 & 1 \\
\hline & & & & 2.2078 & & 1.3 & 2.4 & & & & & Nepheline & 2.163 & 5 \\
\hline & & & & 2.124 & & 0.7 & 2.2 & & & & & Nepheline & 2.1188 & 7 \\
\hline & & & & 2.1051 & & 0.7 & 2.3 & & & & & Nepheline & 2.0938 & 5 \\
\hline \multirow[t]{3}{*}{2.095} & -0.002 & 37.6 & 32.1 & 2.086 & 0.007 & 31.4 & 31.3 & 2.0951 & -0.002 & 33.3 & 32.6 & Sodalite & 2.093 & 20 \\
\hline & & & & 2.0826 & & 17 & 18.9 & & & & & & 2.09 & \\
\hline & & & & 2.0675 & & 1.3 & 2.2 & 2.0077 & & 1.7 & 2.6 & & 2.07 & \\
\hline
\end{tabular}


Table 20. (continued)

\begin{tabular}{|c|c|c|c|c|c|c|c|c|c|c|c|c|c|c|}
\hline \multicolumn{4}{|c|}{$500^{\circ} \mathrm{C} 1$ week } & \multicolumn{4}{|c|}{$500{ }^{\circ} \mathrm{C} 4$ weeks } & \multicolumn{4}{|c|}{$500^{\circ} \mathrm{C} 3$ months } & \multicolumn{3}{|c|}{ Reference phases } \\
\hline$d(\AA)$ & $\begin{array}{l}\text { Peak } \\
\text { shift }\end{array}$ & $\begin{array}{c}1 \% \text { peak } \\
\text { area }\end{array}$ & $\begin{array}{c}1 \% \text { peak } \\
\text { height }\end{array}$ & $d(\AA)$ & $\begin{array}{l}\text { Peak } \\
\text { shift }\end{array}$ & $\begin{array}{c}1 \% \text { peak } \\
\text { area }\end{array}$ & $\begin{array}{c}1 \% \text { peak } \\
\text { height }\end{array}$ & $d(\AA)$ & $\begin{array}{c}\text { Peak } \\
\text { shift }\end{array}$ & $\begin{array}{c}\text { I\% peak } \\
\text { area } \\
\end{array}$ & $\begin{array}{c}1 \% \text { peak } \\
\text { height }\end{array}$ & Phase & $d(\AA)$ & $\begin{array}{c}1 \% \text { peak } \\
\text { height }\end{array}$ \\
\hline 2.0021 & & 4.2 & 2.7 & 1.992 & & 3.9 & 3.7 & 2.0011 & & 3.5 & 3.9 & Halite & 1.994 & 55 \\
\hline \multirow[t]{3}{*}{1.9875} & -0.002 & 7.3 & 4.9 & 1.9788 & 0.006 & 7.2 & 5.9 & 1.9869 & -0.002 & 6 & 6.4 & Sodalite & 1.985 & 3 \\
\hline & & & & 1.9756 & & 2.2 & 4.3 & & & & & Nepheline & 1.9313 & 6 \\
\hline & & & & & & & & & & & & & 1.90 & \\
\hline \multirow[t]{4}{*}{1.8951} & -0.002 & 5 & 4.1 & 1.8872 & 0.006 & 3.9 & 5.1 & 1.8946 & -0.002 & 4.2 & 6.1 & Sodalite & 1.893 & 3 \\
\hline & & & & 1.8747 & & 0.5 & 1.9 & 1.8889 & & 2.7 & 3.2 & & 1.89 & \\
\hline & & & & & & & & 1.8702 & & 0.3 & 2 & Nepheline & 1.8411 & 2 \\
\hline & & & & & & & & & & & & & 1.82 & \\
\hline \multirow[t]{5}{*}{1.8137} & -0.002 & 4.3 & 3.3 & 1.8071 & 0.005 & 4.1 & 4.8 & 1.8138 & -0.002 & 4 & 4.5 & Sodalite & 1.8122 & 2 \\
\hline & & & & & & & & 1.8099 & & 4 & 3.6 & & 1.81 & \\
\hline & & & & & & & & 1.8011 & & 0.6 & 2 & & 1.80 & \\
\hline & & & & 1.7697 & & 0.3 & 1.9 & 1.7898 & & 0.3 & 2 & Nepheline & 1.7923 & 5 \\
\hline & & & & & & & & & & & & & 1.74 & \\
\hline \multirow[t]{7}{*}{1.7427} & -0.001 & 4.9 & 4 & 1.7367 & 0.005 & 3.7 & 4.9 & 1.7411 & 0.000 & 4.4 & 5.1 & Sodalite & 1.7413 & 2 \\
\hline & & & & & & & & 1.7386 & & 2.5 & 3.1 & & 1.74 & \\
\hline & & & & & & & & 1.6996 & & 0.4 & 1.9 & Nepheline & 1.6942 & 5 \\
\hline & & & & 1.6288 & & 1.2 & 1.9 & 1.6754 & & 0.3 & 1.8 & & 1.68 & \\
\hline & & & & & & & & & & & & Nepheline & 1.6346 & 6 \\
\hline & & & & 1.6238 & & 1.4 & 1.9 & 1.6333 & & 1.4 & 2 & Halite & 1.628 & 15 \\
\hline & & & & & & & & & & & & & 1.62 & \\
\hline \multirow[t]{3}{*}{1.6219} & -0.001 & 4.6 & 3.3 & 1.617 & 0.004 & 3.6 & 3.9 & 1.6211 & 0.000 & 3.2 & 4.6 & Sodalite & 1.621 & 2 \\
\hline & & & & 1.6123 & & 2.8 & 2.3 & 1.6169 & & 2.5 & 2.6 & Nepheline & 1.615 & 8 \\
\hline & & & & & & & & & & & & Nepheline & 1.6002 & 4 \\
\hline \multirow[t]{2}{*}{1.5701} & 0.000 & 15.1 & 11 & 1.5652 & 0.004 & 12.9 & 11.4 & 1.5696 & 0.000 & 12.6 & 10.8 & Sodalite & 1.5696 & 5 \\
\hline & & & & & & & & & & & & Nepheline & 1.5614 & 14 \\
\hline 1.5231 & 0.000 & 7.5 & 5.3 & 1.5186 & 0.004 & 5.7 & 5.8 & 1.5226 & 0.000 & 6.5 & 6.6 & Sodalite & 1.5227 & 3 \\
\hline \multirow[t]{4}{*}{1.4796} & 0.000 & 11.6 & 8.5 & 1.4759 & 0.004 & 9.5 & 9.2 & 1.4793 & 0.000 & 9.9 & 9.2 & Sodalite & 1.4797 & 4 \\
\hline & & & & & & & & & & & & & 1.47 & \\
\hline & & & & & & & & & & & & Nepheline & 1.4687 & 5 \\
\hline & & & & & & & & & & & & Nepheline & 1.4555 & 3 \\
\hline \multirow[t]{4}{*}{1.4404} & 0.000 & 12.5 & 9.3 & 1.4368 & 0.004 & 10.3 & 10.1 & 1.4396 & 0.001 & 10.9 & 9.5 & Sodalite & 1.4404 & 5 \\
\hline & & & & & & & & & & & & & 1.43 & \\
\hline & & & & & & & & 1.4129 & & 0.3 & 2.1 & Nepheline & 1.4282 & 7 \\
\hline & & & & & & & & 1.4081 & & 0.4 & 1.9 & Halite & 1.41 & 6 \\
\hline
\end{tabular}


Table 20. (continued)

\begin{tabular}{|c|c|c|c|c|c|c|c|c|c|c|c|c|c|c|}
\hline \multicolumn{4}{|c|}{$500^{\circ} \mathrm{C} 1$ week } & \multicolumn{4}{|c|}{$500^{\circ} \mathrm{C} 4$ weeks } & \multicolumn{4}{|c|}{$500^{\circ} \mathrm{C} 3$ months } & \multicolumn{3}{|c|}{ Reference phases } \\
\hline$d(\AA)$ & $\begin{array}{l}\text { Peak } \\
\text { shift }\end{array}$ & $\begin{array}{c}\text { I\% peak } \\
\text { area }\end{array}$ & $\begin{array}{c}1 \% \text { peak } \\
\text { height }\end{array}$ & $d(\AA)$ & $\begin{array}{l}\text { Peak } \\
\text { shift }\end{array}$ & $\begin{array}{c}1 \% \text { peak } \\
\text { area }\end{array}$ & $\begin{array}{c}1 \% \text { peak } \\
\text { height }\end{array}$ & $d(\AA)$ & $\begin{array}{c}\text { Peak } \\
\text { shift }\end{array}$ & $\begin{array}{c}\text { I\% peak } \\
\text { area }\end{array}$ & $\begin{array}{c}1 \% \text { peak } \\
\text { height }\end{array}$ & Phase & $d(\AA)$ & $\begin{array}{c}\text { I\% peak } \\
\text { height }\end{array}$ \\
\hline & & & & & & & & & & & & & 1.40 & \\
\hline \multirow[t]{3}{*}{1.4036} & 0.000 & 0.5 & 0.7 & 1.4011 & 0.003 & 0.9 & 1.9 & 1.4029 & 0.001 & 1.3 & 2.4 & Sodalite & 1.4038 & 1 \\
\hline & & & & 1.3972 & & 0.9 & 1.7 & 1.3978 & & 0.4 & 1.9 & & 1.40 & \\
\hline & & & & & & & & & & & & Nepheline & 1.3865 & 6 \\
\hline \multirow[t]{2}{*}{1.3697} & 0.000 & 5.7 & 3.5 & 1.3668 & 0.003 & 4.1 & 4.3 & 1.3694 & 0.000 & 4.1 & 4.5 & Sodalite & 1.3699 & 2 \\
\hline & & & & & & & & & & & & & 1.37 & \\
\hline \multirow[t]{2}{*}{1.338} & 0.000 & 5.9 & 3.5 & 1.3353 & 0.003 & 3.4 & 4.6 & 1.3379 & 0.001 & 5 & 4.9 & Sodalite & 1.3385 & 2 \\
\hline & & & & & & & & & & & & & 1.33 & \\
\hline \multirow[t]{2}{*}{1.3087} & 0.000 & 5.5 & 3.6 & 1.3063 & 0.003 & 3.3 & 4.4 & 1.308 & 0.001 & 4.7 & 5 & Sodalite & 1.3091 & 2 \\
\hline & & & & & & & & 1.3004 & & 0.4 & 1.8 & & 1.30 & \\
\hline \multirow[t]{2}{*}{1.2811} & 0.000 & 3.1 & 2.4 & 1.2825 & -0.001 & 0.4 & 1.6 & 1.2806 & 0.001 & 3.7 & 3.8 & Sodalite & 1.2814 & 2 \\
\hline & & & & 1.2782 & 0.001 & 3.2 & 3.4 & & & & & Nepheline & 1.279 & 6 \\
\hline
\end{tabular}


Table 20. (continued)

\begin{tabular}{|c|c|c|c|c|c|c|c|c|c|c|}
\hline \multicolumn{4}{|c|}{$500^{\circ} \mathrm{C} 6$ months } & \multicolumn{4}{|c|}{$500^{\circ} \mathrm{C} 1$ year } & \multicolumn{3}{|c|}{ Reference phases } \\
\hline \multirow[t]{11}{*}{$d(\AA)$} & $\begin{array}{l}\text { Peak } \\
\text { shift }\end{array}$ & $\begin{array}{c}1 \% \text { peak } \\
\text { area }\end{array}$ & $\begin{array}{c}1 \% \text { peak } \\
\text { height }\end{array}$ & $d(\AA)$ & $\begin{array}{l}\text { Peak } \\
\text { shift }\end{array}$ & $\begin{array}{c}1 \% \text { peak } \\
\text { area } \\
\end{array}$ & $\begin{array}{c}1 \% \text { peak } \\
\text { height }\end{array}$ & Phase & $d(\AA)$ & $\begin{array}{c}\text { I\% peak } \\
\text { height }\end{array}$ \\
\hline & & & & & & & & & 8.57 & \\
\hline & & & & & & & & & 7.71 & \\
\hline & & & & & & & & & 7.19 & \\
\hline & & & & & & & & & 7.01 & \\
\hline & & & & & & & & & 6.98 & \\
\hline & & & & & & & & & 6.85 & \\
\hline & & & & & & & & & 6.56 & \\
\hline & & & & & & & & & 6.52 & \\
\hline & & & & & & & & & 6.48 & \\
\hline & & & & & & & & & 6.31 & \\
\hline \multirow[t]{10}{*}{6.3458} & -0.066 & 28.6 & 28.9 & 6.2806 & -0.001 & 26.9 & 26.0 & Sodalite & 6.28 & 40 \\
\hline & & & & & & & & & 5.81 & \\
\hline & & & & & & & & & 5.64 & \\
\hline & & & & & & & & & 5.40 & \\
\hline & & & & & & & & & 5.20 & \\
\hline & & & & & & & & Nepheline & 5.0058 & 10 \\
\hline & & & & & & & & & 4.81 & \\
\hline & & & & & & & & & 4.73 & \\
\hline & & & & & & & & & 4.51 & \\
\hline & & & & & & & & & 4.49 & \\
\hline \multirow[t]{9}{*}{4.4695} & -0.029 & 6.7 & 6.7 & 4.4363 & 0.004 & 4.3 & 6.2 & Sodalite & 4.44 & 5 \\
\hline & & & & & & & & & 4.35 & \\
\hline & & & & & & & & Nepheline & 4.3335 & 35 \\
\hline & & & & & & & & & 4.30 & \\
\hline & & & & & & & & & 4.29 & \\
\hline & & & & & & & & & 4.22 & \\
\hline & & & & & & & & Nepheline & 4.1766 & 80 \\
\hline & & & & & & & & & 4.15 & \\
\hline & & & & & & & & & 4.01 & \\
\hline \multirow[t]{6}{*}{3.9936} & -0.024 & 0.5 & 1 & 3.9684 & 0.002 & 1.9 & 1.2 & Sodalite & 3.97 & 1 \\
\hline & & & & & & & & & 3.89 & \\
\hline & & & & & & & & Nepheline & 3.8438 & 100 \\
\hline & & & & & & & & & 3.79 & \\
\hline & & & & & & & & Nepheline & 3.7614 & 2 \\
\hline & & & & & & & & & 3.70 & \\
\hline 3.6434 & -0.019 & 100 & 100 & 3.6211 & 0.003 & 100 & 100 & Sodalite & 3.624 & 100 \\
\hline
\end{tabular}


Table 20. (continued)

\begin{tabular}{|c|c|c|c|c|c|c|c|c|c|c|}
\hline \multicolumn{4}{|c|}{$500^{\circ} \mathrm{C} 6$ months } & \multicolumn{4}{|c|}{$500^{\circ} \mathrm{C} 1$ year } & \multicolumn{3}{|c|}{ Reference phases } \\
\hline \multirow[t]{14}{*}{$d(\AA)$} & $\begin{array}{l}\text { Peak } \\
\text { shift }\end{array}$ & $\begin{array}{c}1 \% \text { peak } \\
\text { area }\end{array}$ & $\begin{array}{c}1 \% \text { peak } \\
\text { height }\end{array}$ & $d(\AA)$ & $\begin{array}{l}\text { Peak } \\
\text { shift }\end{array}$ & $\begin{array}{c}1 \% \text { peak } \\
\text { area }\end{array}$ & $\begin{array}{c}\text { I\% peak } \\
\text { height }\end{array}$ & Phase & $d(\AA)$ & $\begin{array}{c}1 \% \text { peak } \\
\text { height }\end{array}$ \\
\hline & & & & & & & & & 3.57 & \\
\hline & & & & 3.3419 & & 2.4 & 1.9 & & 3.31 & \\
\hline & & & & & & & & Nepheline & 3.2731 & 70 \\
\hline & & & & & & & & Halite & 3.26 & 13 \\
\hline & & & & & & & & & 3.24 & \\
\hline & & & & & & & & & 3.17 & \\
\hline & & & & & & & & & 3.11 & \\
\hline & & & & & & & & & 3.06 & \\
\hline & & & & & & & & Nepheline & 3.0461 & 18 \\
\hline & & & & & & & & Nepheline & 3.0059 & 100 \\
\hline & & & & & & & & Nepheline & 2.8864 & 35 \\
\hline & & & & & & & & & 2.86 & \\
\hline & & & & & & & & & 2.84 & \\
\hline 2.8365 & & 13.9 & 4.4 & 2.8238 & & 6.8 & 4.9 & Halite & 2.821 & 100 \\
\hline \multirow[t]{5}{*}{2.816} & -0.009 & 11.7 & 8.3 & 2.8031 & 0.004 & 10.5 & 9.4 & Sodalite & 2.807 & 8 \\
\hline & & & & & & & & & 2.76 & \\
\hline & & & & & & & & & 2.71 & \\
\hline & & & & & & & & & 2.66 & \\
\hline & & & & & & & & & 2.59 & \\
\hline \multirow[t]{3}{*}{2.569} & -0.006 & 19.9 & 20.1 & 2.5582 & 0.005 & 19.1 & 19.1 & Sodalite & 2.563 & 16 \\
\hline & & & & & & & & Nepheline & 2.50 & 14 \\
\hline & & & & & & & & & 2.39 & \\
\hline \multirow[t]{6}{*}{2.3777} & -0.005 & 21.9 & 20.3 & 2.3686 & 0.004 & 20.8 & 20.1 & Sodalite & 2.373 & 16 \\
\hline & & & & & & & & & 2.35 & \\
\hline & & & & & & & & Nepheline & 2.3395 & 35 \\
\hline & & & & & & & & Nepheline & 2.3074 & 25 \\
\hline & & & & & & & & & 2.27 & \\
\hline & & & & & & & & & 2.23 & \\
\hline \multirow[t]{4}{*}{2.2233} & -0.004 & 0.9 & 1.3 & 2.2148 & 0.004 & 1.3 & 1.0 & Sodalite & 2.219 & 1 \\
\hline & & & & & & & & Nepheline & 2.163 & 5 \\
\hline & & & & & & & & Nepheline & 2.1188 & 7 \\
\hline & & & & & & & & Nepheline & 2.0938 & 5 \\
\hline \multirow[t]{3}{*}{2.0962} & -0.003 & 31.8 & 27.8 & 2.0893 & 0.004 & 31.0 & 26.9 & Sodalite & 2.093 & 20 \\
\hline & & & & & & & & & 2.09 & \\
\hline & & & & & & & & & 2.07 & \\
\hline
\end{tabular}


Table 20. (continued)

\begin{tabular}{|c|c|c|c|c|c|c|c|c|c|c|}
\hline \multicolumn{4}{|c|}{$500^{\circ} \mathrm{C} 6$ months } & \multicolumn{4}{|c|}{$500^{\circ} \mathrm{C} 1$ year } & \multicolumn{3}{|c|}{ Phase ID } \\
\hline$d(\AA)$ & $\begin{array}{l}\text { Peak } \\
\text { shift }\end{array}$ & $\begin{array}{c}\text { I\% peak } \\
\text { area }\end{array}$ & $\begin{array}{c}1 \% \text { peak } \\
\text { height }\end{array}$ & $d(\AA)$ & $\begin{array}{c}\text { Peak } \\
\text { shift }\end{array}$ & $\begin{array}{c}1 \% \text { peak } \\
\text { area }\end{array}$ & $\begin{array}{c}1 \% \text { peak } \\
\text { height }\end{array}$ & Phase & $d(\AA)$ & $\begin{array}{c}1 \% \text { peak } \\
\text { height }\end{array}$ \\
\hline 2.0024 & & 4.9 & 2.2 & 1.9971 & & 3.5 & 2 & Halite & 1.994 & 55 \\
\hline \multirow[t]{3}{*}{1.9876} & -0.003 & 7.0 & 4.2 & 1.9815 & 0.004 & 5.3 & 4.2 & Sodalite & 1.985 & 3 \\
\hline & & & & & & & & Nepheline & 1.9313 & 6 \\
\hline & & & & & & & & & 1.90 & \\
\hline \multirow[t]{4}{*}{1.895} & -0.002 & 4.3 & 3.8 & 1.8897 & 0.003 & 3.9 & 3.7 & Sodalite & 1.893 & 3 \\
\hline & & & & & & & & & 1.89 & \\
\hline & & & & & & & & Nepheline & 1.8411 & 2 \\
\hline & & & & & & & & & 1.82 & \\
\hline \multirow[t]{5}{*}{1.8139} & -0.002 & 3.9 & 3.3 & 1.809 & 0.003 & 3.6 & 2.9 & Sodalite & 1.8122 & 2 \\
\hline & & & & & & & & & 1.81 & \\
\hline & & & & & & & & & 1.80 & \\
\hline & & & & & & & & Nepheline & 1.7923 & 5 \\
\hline & & & & & & & & & 1.74 & \\
\hline \multirow[t]{5}{*}{1.7427} & -0.001 & 3.7 & 2.9 & 1.7383 & 0.003 & 3.4 & 3.3 & Sodalite & 1.7413 & 2 \\
\hline & & & & & & & & & 1.74 & \\
\hline & & & & & & & & Nepheline & 1.6942 & 5 \\
\hline & & & & & & & & & 1.68 & \\
\hline & & & & & & & & Nepheline & 1.6346 & 6 \\
\hline \multirow[t]{2}{*}{1.6332} & & 1.9 & 0.8 & 1.6298 & & 2 & 0.6 & Halite & 1.628 & 15 \\
\hline & & & & & & & & & 1.62 & \\
\hline \multirow[t]{3}{*}{1.6218} & -0.001 & 3.8 & 2.7 & 1.6181 & 0.003 & 3.6 & 2.7 & Sodalite & 1.621 & 2 \\
\hline & & & & & & & & Nepheline & 1.615 & 8 \\
\hline & & & & & & & & Nepheline & 1.6002 & 4 \\
\hline \multirow[t]{2}{*}{1.5701} & 0.000 & 12.9 & 10.5 & 1.5667 & 0.003 & 11.5 & 8.7 & Sodalite & 1.5696 & 5 \\
\hline & & & & & & & & Nepheline & 1.5614 & 14 \\
\hline 1.5231 & 0.000 & 5.8 & 4.9 & 1.5198 & 0.003 & 5.8 & 4.4 & Sodalite & 1.5227 & 3 \\
\hline \multirow[t]{4}{*}{1.4796} & 0.000 & 8.7 & 6.5 & 1.4772 & 0.002 & 9.5 & 7 & Sodalite & 1.4797 & 4 \\
\hline & & & & & & & & & 1.47 & \\
\hline & & & & & & & & Nepheline & 1.4687 & 5 \\
\hline & & & & & & & & Nepheline & 1.4555 & 3 \\
\hline \multirow[t]{5}{*}{1.4404} & 0.000 & 10 & 7.6 & 1.4376 & 0.003 & 10.2 & 7.6 & Sodalite & 1.4404 & 5 \\
\hline & & & & & & & & & 1.43 & \\
\hline & & & & & & & & Nepheline & 1.4282 & 7 \\
\hline & & & & & & & & Halite & 1.41 & 6 \\
\hline & & & & & & & & & 1.4081 & 1.9 \\
\hline
\end{tabular}


Table 20. (continued)

\begin{tabular}{|c|c|c|c|c|c|c|c|c|c|c|}
\hline \multicolumn{4}{|c|}{$500^{\circ} \mathrm{C} 6$ months } & \multicolumn{4}{|c|}{$500^{\circ} \mathrm{C} 1$ year } & \multicolumn{3}{|c|}{ Phase ID } \\
\hline \multirow[t]{4}{*}{$d(\AA)$} & $\begin{array}{l}\text { Peak } \\
\text { shift }\end{array}$ & $\begin{array}{c}1 \% \text { peak } \\
\text { area }\end{array}$ & $\begin{array}{c}1 \% \text { peak } \\
\text { height }\end{array}$ & $d(\AA)$ & $\begin{array}{c}\text { Peak } \\
\text { shift }\end{array}$ & $\begin{array}{c}\text { I\% peak } \\
\text { area }\end{array}$ & $\begin{array}{c}\text { I\% peak } \\
\text { height }\end{array}$ & Phase & $d(\AA)$ & $\begin{array}{c}\text { I\% peak } \\
\text { height }\end{array}$ \\
\hline & & & & 1.4017 & 0.002 & 0.7 & 0.7 & Sodalite & 1.4038 & 1 \\
\hline & & & & & & & & & 1.40 & \\
\hline & & & & & & & & Nepheline & 1.3865 & 6 \\
\hline \multirow[t]{2}{*}{1.3701} & 0.000 & 4.2 & 3.2 & 1.3671 & 0.003 & 4.1 & 2.6 & Sodalite & 1.3699 & 2 \\
\hline & & & & & & & & & 1.37 & \\
\hline \multirow[t]{2}{*}{1.338} & 0.000 & 3.8 & 2.8 & 1.3357 & 0.003 & 4.7 & 2.7 & Sodalite & 1.3385 & 2 \\
\hline & & & & & & & & & 1.33 & \\
\hline \multirow[t]{2}{*}{1.3088} & 0.000 & 4.4 & 3 & 1.3067 & 0.002 & 3.7 & 2.6 & Sodalite & 1.3091 & 2 \\
\hline & & & & & & & & & 1.30 & \\
\hline \multirow[t]{2}{*}{1.2812} & 0.000 & 3 & 2.1 & 1.2792 & 0.002 & 2.2 & 1.7 & Sodalite & 1.2814 & 2 \\
\hline & & & & & & & & Nepheline & 1.279 & 6 \\
\hline
\end{tabular}


Table 21. Compilation of area\% values used to compare relative amounts of sodalite, nepheline, and halite in long-term heat-treated CWF materials

\begin{tabular}{|c|c|c|c|c|c|c|c|c|c|c|c|}
\hline \multirow{2}{*}{$\stackrel{d \text {-spacing, }}{\AA}$} & \multirow{2}{*}{$\begin{array}{l}\text { No-heat } \\
\text { CWF }^{a}\end{array}$} & \multicolumn{5}{|c|}{ Heat-treated at $400^{\circ} \mathrm{C}$} & \multicolumn{5}{|c|}{ Heat-treated at $500^{\circ} \mathrm{C}$} \\
\hline & & 1 week & 4 weeks & 3 months & 6 months & 1 year & 1 week & 4 weeks & 3 months & 6 months & 1 year \\
\hline \multicolumn{12}{|c|}{ Halite } \\
\hline 3.26 & $0.4 \pm 1.0$ & $\mathrm{nd}^{\mathrm{b}}$ & nd & nd & nd & nd & 0.8 & 0.8 & 0.9 & nd & nd \\
\hline 2.821 & $5.5 \pm 1.2$ & Not resolved & $14.7^{c}$ & 5.9 & 10.3 & 12.4 & Not resolved & 6.9 & 7.6 & 13.9 & 6.8 \\
\hline 1.994 & $2.5 \pm 0.3$ & 4.3 & 5.0 & 4.1 & 3.1 & 4.8 & 4.2 & 3.9 & 3.5 & 4.9 & 3.5 \\
\hline 1.628 & $0.7 \pm 0.3$ & nd & 1.6 & nd & nd & nd & nd & 1.4 & 1.4 & 1.9 & 2.0 \\
\hline 1.41 & 0 & nd & 0.3 & nd & nd & nd & nd & nd & 0.4 & nd & nd \\
\hline \multicolumn{12}{|c|}{ Sodalite } \\
\hline 6.28 & $25.5 \pm 3.2$ & 26.1 & 26.1 & 27.4 & 25.8 & 29.8 & 26.4 & 29.1 & 25.2 & 28.6 & 26.9 \\
\hline 3.624 & $100 \pm 0$ & 100 & 100 & 100 & 100 & 100 & 100 & 100 & 100 & 100 & 100 \\
\hline 2.563 & $18.8 \pm 2.2$ & 19.1 & 20.9 & 19.6 & 19.4 & 26.8 & 24.8 & 20.4 & 20.1 & 19.9 & 19.1 \\
\hline 2.373 & $18.9 \pm 1.1$ & 23.0 & 22.3 & 20.2 & 19.6 & 25.8 & 26.0 & 19.9 & 21.2 & 21.9 & 20.8 \\
\hline 2.093 & $27.3 \pm 2.4$ & 40.0 & 32.9 & 30.5 & 30.0 & 40.6 & 37.6 & 31.4 & 33.3 & 31.8 & 31.0 \\
\hline \multicolumn{12}{|c|}{ Nepheline } \\
\hline 4.3335 & 0 & nd & nd & nd & nd & nd & nd & nd & nd & nd & nd \\
\hline 4.1766 & 0 & nd & nd & nd & nd & nd & nd & nd & nd & nd & nd \\
\hline 3.8438 & 0 & nd & nd & nd & nd & nd & nd & nd & nd & nd & nd \\
\hline 3.2731 & 0 & nd & 1.5 & nd & nd & nd & nd & nd & nd & nd & nd \\
\hline 3.0059 & 0 & nd & nd & nd & nd & nd & nd & nd & 0.7 & nd & nd \\
\hline 2.8864 & 0 & nd & nd & nd & nd & nd & nd & nd & 0.6 & nd & nd \\
\hline 2.3395 & 0 & nd & nd & nd & nd & nd & nd & nd & nd & nd & nd \\
\hline
\end{tabular}

${ }^{\mathrm{a}}$ Mean \pm 2 standard deviations from replicate analyses of source CWF material PC10402.

b "nd" indicates that a quantifiable peak was not detected at this $d$-spacing.

${ }^{\mathrm{c}}$ Values shown in bold font exceed the mean 2 standard deviations of I\% peak area for CWF material PC10402. 
Table 22. Results of replicate XRD analyses of CWF source material PC10402

\begin{tabular}{|c|c|c|c|c|c|c|c|c|c|c|c|c|c|c|}
\hline \multicolumn{4}{|c|}{ Analysis 1} & \multicolumn{4}{|c|}{ Analysis 2} & \multicolumn{4}{|c|}{ Analysis 3} & \multicolumn{3}{|c|}{ Reference phase } \\
\hline$d(\AA)$ & Peak shift & $\begin{array}{c}1 \% \text { peak } \\
\text { area }\end{array}$ & $\begin{array}{c}\text { I\% peak } \\
\text { height }\end{array}$ & $d(\AA)$ & Peak shift & $\begin{array}{c}1 \% \text { peak } \\
\text { area }\end{array}$ & $\begin{array}{c}\text { I\% peak } \\
\text { height }\end{array}$ & $d(\AA)$ & Peak shift & $\begin{array}{c}\text { I\% peak } \\
\text { area }\end{array}$ & $\begin{array}{c}1 \% \text { peak } \\
\text { height }\end{array}$ & ID & $d(\AA)$ & $\begin{array}{c}1 \% \text { peak } \\
\text { height }\end{array}$ \\
\hline \multirow[t]{4}{*}{6.2766} & 0.0034 & 23.8 & 24.7 & 6.2848 & -0.0048 & 26.9 & 27.3 & 6.2933 & -0.0133 & 25.8 & 26.5 & Sodalite & 6.28 & 40 \\
\hline & & & & & & & & & & & & & 5.76 & \\
\hline & & & & & & & & & & & & Nepheline & 5.0058 & 10 \\
\hline & & & & & & & & & & & & & 4.86 & \\
\hline \multirow[t]{4}{*}{4.4326} & 0.0074 & 6.7 & 7.0 & 4.4369 & 0.0031 & 7.0 & 7.6 & 4.4444 & -0.0044 & 6.3 & 6.7 & Sodalite & 4.44 & 5 \\
\hline & & & & & & & & & & & & & 4.20 & \\
\hline & & & & & & & & & & & & Nepheline & 4.3335 & 35 \\
\hline & & & & & & & & & & & & Nepheline & 4.1766 & 80 \\
\hline \multirow[t]{5}{*}{3.9629} & 0.0071 & 1.3 & 1.8 & 3.9726 & -0.0026 & 1.0 & 1.5 & 3.9671 & 0.0029 & 1.1 & 1.1 & Sodalite & 3.97 & 1 \\
\hline & & & & & & & & & & & & & 3.9 & \\
\hline & & & & & & & & & & & & Nepheline & 3.8438 & 100 \\
\hline & & & & & & & & & & & & Nepheline & 3.7614 & 2 \\
\hline & & & & & & & & & & & & & 3.70 & \\
\hline \multirow[t]{4}{*}{3.6215} & 0.0025 & 100 & 100 & 3.6244 & -0.0004 & 100 & 100 & 3.6248 & -0.0008 & 100 & 100 & Sodalite & 3.624 & 100 \\
\hline & & & & & & & & & & & & & 3.58 & \\
\hline & & & & & & & & & & & & & 3.53 & \\
\hline & & & & & & & & & & & & Nepheline & 3.2731 & 70 \\
\hline \multirow[t]{5}{*}{3.2592} & & 1.0 & 1.0 & 3.2661 & & 0.9 & 1.9 & & & & & Halite & 3.26 & 13 \\
\hline & & & & & & & & & & & & & 3.15 & \\
\hline & & & & & & & & 3.0407 & & 0.7 & 0.4 & Nepheline & 3.0461 & 18 \\
\hline & & & & & & & & & & & & Nepheline & 3.0059 & 100 \\
\hline & & & & & & & & & & & & Nepheline & 2.8864 & 35 \\
\hline 2.8237 & & 5.6 & 17.5 & 2.8239 & & 6.1 & 9.6 & 2.8286 & & 5.6 & 10.2 & Halite & 2.821 & 100 \\
\hline \multirow[t]{2}{*}{2.8047} & 0.0023 & 9.2 & 15.3 & 2.8035 & 0.0035 & 8.1 & 14.8 & 2.8066 & 0.0004 & 8.4 & 10.9 & Sodalite & 2.807 & 8 \\
\hline & & & & & & & & & & & & & 2.70 & \\
\hline \multirow[t]{4}{*}{2.5601} & 0.0029 & 18.4 & 19.4 & 2.5602 & 0.0028 & 18.5 & 19.2 & 2.5616 & 0.0014 & 18.2 & 20.0 & Sodalite & 2.563 & 16 \\
\hline & & & & & & & & & & & & & 2.54 & \\
\hline & & & & & & & & & & & & Nepheline & 2.5000 & 14 \\
\hline & & & & & & & & & & & & Nepheline & 2.4007 & 10 \\
\hline \multirow[t]{2}{*}{2.3696} & 0.0034 & 18.6 & 20.5 & 2.3707 & 0.0023 & 18.9 & 20.5 & 2.3709 & 0.0021 & 18.3 & 20.2 & Sodalite & 2.373 & 16 \\
\hline & & & & & & & & & & & & Nepheline & 2.3395 & 35 \\
\hline
\end{tabular}


Table 22. (continued)

\begin{tabular}{|c|c|c|c|c|c|c|c|c|c|c|c|c|c|c|}
\hline \multicolumn{4}{|c|}{ Analysis 1} & \multicolumn{4}{|c|}{ Analysis 2} & \multicolumn{4}{|c|}{ Analysis 3} & \multicolumn{3}{|c|}{ Reference phase } \\
\hline \multirow[t]{3}{*}{$d(\AA)$} & Peak shift & $\begin{array}{c}1 \% \text { peak } \\
\text { area }\end{array}$ & $\begin{array}{c}1 \% \text { peak } \\
\text { height }\end{array}$ & $d(\AA)$ & Peak shift & $\begin{array}{c}1 \% \text { peak } \\
\text { area }\end{array}$ & $\begin{array}{c}1 \% \text { peak } \\
\text { height }\end{array}$ & $d(\AA)$ & Peak shift & $\begin{array}{c}1 \% \text { peak } \\
\text { area }\end{array}$ & $\begin{array}{c}\text { I\% peak } \\
\text { height }\end{array}$ & ID & $d(\AA)$ & $\begin{array}{c}1 \% \text { peak } \\
\text { height }\end{array}$ \\
\hline & & & & & & & & & & & & Nepheline & 2.3074 & 25 \\
\hline & & & & & & & & & & & & & 2.289 & \\
\hline \multirow[t]{4}{*}{2.2159} & 0.0031 & 1.1 & 1.6 & 2.2189 & 0.0001 & 1.2 & 1.4 & 2.2191 & -0.0001 & 1.0 & 1.8 & Sodalite & 2.219 & 1 \\
\hline & & & & & & & & & & & & Nepheline & 2.163 & 5 \\
\hline & & & & & & & & & & & & Nepheline & 2.1188 & 7 \\
\hline & & & & & & & & & & & & Nepheline & 2.0938 & 5 \\
\hline \multirow[t]{3}{*}{2.0897} & 0.0033 & 28.2 & 30.9 & 2.0898 & 0.0032 & 27.2 & 31.0 & 2.0906 & 0.0024 & 25.6 & 31.0 & Sodalite & 2.093 & 20 \\
\hline & & & & & & & & & & & & & 2.074 & \\
\hline & & & & & & & & & & & & & 2.064 & \\
\hline 1.9954 & & 2.4 & 6.0 & 1.9992 & & 2.3 & 4.9 & 1.9976 & & 2.6 & 7.1 & Halite & 1.994 & 55 \\
\hline \multirow[t]{2}{*}{1.9827} & 0.0023 & 4.2 & 6.5 & 1.9828 & 0.0022 & 4.3 & 8.8 & 1.9836 & 0.0014 & 4.2 & 7.0 & Sodalite & 1.985 & 3 \\
\hline & & & & & & & & & & & & Nepheline & 1.9313 & 6 \\
\hline \multirow[t]{2}{*}{1.8901} & 0.0029 & 3.6 & 3.7 & 1.8908 & 0.0022 & 3.3 & 3.7 & 1.8909 & 0.0021 & 3.4 & 3.7 & Sodalite & 1.893 & 3 \\
\hline & & & & & & & & & & & & Nepheline & 1.8411 & 2 \\
\hline \multirow[t]{2}{*}{1.8093} & 0.0029 & 3.2 & 3.7 & 1.8103 & 0.0019 & 2.9 & 3.5 & 1.8104 & 0.0018 & 2.8 & 3.7 & Sodalite & 1.8122 & 2 \\
\hline & & & & & & & & & & & & Nepheline & 1.7923 & 5 \\
\hline \multirow[t]{4}{*}{1.7385} & 0.0028 & 3.8 & 3.7 & 1.7391 & 0.0022 & 2.9 & 3.9 & 1.7391 & 0.0022 & 3.0 & 4.0 & Sodalite & 1.7413 & 2 \\
\hline & & & & & & & & & & & & & 1.72 & \\
\hline & & & & & & & & & & & & Nepheline & 1.6942 & 5 \\
\hline & & & & & & & & & & & & Nepheline & 1.6346 & 6 \\
\hline 1.6279 & & 0.6 & 1.1 & 1.63 & & 0.8 & 2.2 & 1.63 & & 0.7 & 2.2 & Halite & 1.628 & 15 \\
\hline \multirow[t]{3}{*}{1.618} & 0.003 & 2.2 & 3.5 & 1.6185 & 0.0025 & 2.7 & 4.0 & 1.619 & 0.002 & 2.1 & 3.8 & Sodalite & 1.621 & 2 \\
\hline & & & & & & & & & & & & Nepheline & 1.615 & 8 \\
\hline & & & & & & & & & & & & Nepheline & 1.6002 & 4 \\
\hline \multirow[t]{2}{*}{1.5667} & 0.0029 & 8.3 & 11.1 & 1.5672 & 0.0024 & 8.8 & 11.7 & 1.5672 & 0.0024 & 8.7 & 11.8 & Sodalite & 1.5696 & 5 \\
\hline & & & & & & & & & & & & Nepheline & 1.5614 & 14 \\
\hline 1.5203 & 0.0024 & 4.4 & 6.3 & 1.5204 & 0.0023 & 4.1 & 5.8 & 1.5204 & 0.0023 & 4.4 & 6.6 & Sodalite & 1.5227 & 3 \\
\hline \multirow[t]{5}{*}{1.4772} & 0.0025 & 6.6 & 9.8 & 1.4772 & 0.0025 & 6.7 & 9.4 & 1.4776 & 0.0021 & 6.2 & 9.3 & Sodalite & 1.4797 & 4 \\
\hline & & & & & & & & & & & & & 1.474 & \\
\hline & & & & & & & & & & & & Nepheline & 1.4687 & 5 \\
\hline & & & & & & & & & & & & & 1.463 & \\
\hline & & & & & & & & & & & & Nepheline & 1.4555 & 3 \\
\hline
\end{tabular}


Table 22. (continued)

\begin{tabular}{|c|c|c|c|c|c|c|c|c|c|c|c|c|c|c|}
\hline \multicolumn{4}{|c|}{ Analysis 1} & \multicolumn{4}{|c|}{ Analysis 2} & \multicolumn{4}{|c|}{ Analysis 3} & \multicolumn{3}{|c|}{ Reference phase } \\
\hline$d(\AA)$ & Peak shift & $\begin{array}{c}1 \% \text { peak } \\
\text { area }\end{array}$ & $\begin{array}{c}\text { I\% peak } \\
\text { height }\end{array}$ & $d(\AA)$ & Peak shift & $\begin{array}{c}1 \% \text { peak } \\
\text { area }\end{array}$ & $\begin{array}{c}\text { I\% peak } \\
\text { height }\end{array}$ & $d(\AA)$ & Peak shift & $\begin{array}{c}\text { I\% peak } \\
\text { area }\end{array}$ & $\begin{array}{c}\text { I\% peak } \\
\text { height }\end{array}$ & ID & $d(\AA)$ & $\begin{array}{c}\text { I\% peak } \\
\text { height }\end{array}$ \\
\hline \multirow[t]{3}{*}{1.4376} & 0.0028 & 7.3 & 10.7 & 1.4383 & 0.0021 & 6.7 & 9.1 & 1.4383 & 0.0021 & 6.2 & 9.3 & Sodalite & 1.4404 & 5 \\
\hline & & & & & & & & & & & & Nepheline & 1.4282 & 7 \\
\hline & & & & & & & & & & & & Halite & 1.41 & 6 \\
\hline \multirow[t]{2}{*}{1.401} & 0.0028 & 0.7 & 0.5 & 1.4008 & 0.003 & 0.6 & 1.3 & 1.4012 & 0.0026 & 0.6 & 0.9 & Sodalite & 1.4038 & 1 \\
\hline & & & & & & & & & & & & Nepheline & 1.3865 & 6 \\
\hline 1.3676 & 0.0023 & 2.6 & 3.9 & 1.3679 & 0.002 & 2.6 & 3.6 & 1.3679 & 0.002 & 2.5 & 4.2 & Sodalite & 1.3699 & 2 \\
\hline \multirow[t]{2}{*}{1.3363} & 0.0022 & 3.1 & 4.2 & 1.336 & 0.0025 & 2.5 & 4.1 & 1.3366 & 0.0019 & 2.3 & 3.9 & Sodalite & 1.3385 & 2 \\
\hline & & & & & & & & & & & & & 1.34 & \\
\hline \multirow[t]{2}{*}{1.3067} & 0.0024 & 2.7 & 4.2 & 1.307 & 0.0021 & 2.5 & 4.3 & 1.3068 & 0.0023 & 2.7 & 4.1 & Sodalite & 1.3091 & 2 \\
\hline & & & & 1.3036 & & 1.7 & 2.3 & & & & & & 1.31 & \\
\hline \multirow[t]{4}{*}{1.2793} & 0.0021 & 2.0 & 2.9 & 1.2791 & 0.0023 & 1.9 & 2.9 & 1.2796 & 0.0018 & 1.9 & 3.0 & Sodalite & 1.2814 & 2 \\
\hline & & & & & & & & & & & & Nepheline & 1.279 & 6 \\
\hline & & & & 1.2622 & 0.0062 & 0.5 & 1.0 & 1.2627 & 0.0057 & 0.6 & 1.2 & Sodalite & 1.2684 & 1 \\
\hline & & & & & & & & & & & & Sodalite & 1.2555 & 1 \\
\hline 1.229 & & 0.5 & 0.9 & & & & & & & & & Nepheline & 1.2347 & 4 \\
\hline 1.2263 & & 0.4 & 0.8 & 1.2293 & & 0.6 & 0.9 & 1.229 & & 0.5 & 1.2 & & 1.23 & \\
\hline 1.2057 & 0.0024 & 5.9 & 8.5 & 1.2061 & 0.002 & 5.7 & 9.7 & 1.2061 & 0.002 & 5.2 & 8.7 & Sodalite & 1.2081 & 3 \\
\hline
\end{tabular}


Table 22. (continued)

\begin{tabular}{|c|c|c|c|c|c|c|c|c|c|c|}
\hline \multicolumn{4}{|c|}{ Analysis 4} & \multicolumn{4}{|c|}{ Analysis 5} & \multicolumn{3}{|c|}{ Reference phase } \\
\hline$d(\AA)$ & Peak shift & $\begin{array}{l}\text { I\% peak } \\
\text { area }\end{array}$ & $\begin{array}{c}\text { I\% peak } \\
\text { height }\end{array}$ & $d(\AA)$ & Peak shift & $\begin{array}{c}1 \% \text { peak } \\
\text { area }\end{array}$ & $\begin{array}{c}\text { I\% peak } \\
\text { height }\end{array}$ & ID & $d(\AA)$ & $\begin{array}{c}1 \% \text { peak } \\
\text { height }\end{array}$ \\
\hline 6.3037 & -0.0237 & 23.9 & 26.6 & 6.3494 & -0.0694 & 27.0 & 31.4 & Sodalite & 6.28 & 40 \\
\hline \multirow[t]{2}{*}{5.2267} & & 0.4 & 0.1 & & & & & & 5.76 & \\
\hline & & & & & & & & Nepheline & 5.0058 & 10 \\
\hline 4.9016 & & 0.5 & 0.7 & & & & & & 4.86 & \\
\hline 4.4494 & -0.0094 & 6.8 & 7.1 & 4.4687 & -0.0287 & 6.7 & 6.5 & Sodalite & 4.44 & 5 \\
\hline \multirow[t]{3}{*}{4.1114} & & 0.6 & 0.2 & & & & & & 4.20 & \\
\hline & & & & & & & & Nepheline & 4.3335 & 35 \\
\hline & & & & & & & & Nepheline & 4.1766 & 80 \\
\hline 3.9738 & -0.0038 & 1.2 & 1.3 & 3.9959 & -0.0259 & 1.0 & 0.9 & Sodalite & 3.97 & 1 \\
\hline \multirow[t]{2}{*}{3.8815} & & 0.6 & 0.6 & & & & & & 3.9 & \\
\hline & & & & & & & & Nepheline & 3.8438 & 100 \\
\hline 3.7539 & & 0.8 & 0.5 & & & & & Nepheline & 3.7614 & 2 \\
\hline 3.7071 & & 0.9 & 0.7 & & & & & & 3.70 & \\
\hline 3.6302 & -0.0062 & 100 & 100 & 3.6449 & -0.0209 & 100 & 100 & Sodalite & 3.624 & 100 \\
\hline 3.4786 & & 0.7 & 0.4 & & & & & & 3.58 & \\
\hline \multirow[t]{3}{*}{3.4464} & & 0.7 & 0.8 & 3.5463 & & 0.6 & 0.2 & & 3.53 & \\
\hline & & & & 3.2813 & & 0.9 & 0.4 & Nepheline & 3.2731 & 70 \\
\hline & & & & & & & & Halite & 3.26 & 13 \\
\hline 3.1857 & & 0.6 & 0.5 & & & & & & 3.15 & \\
\hline 3.0345 & & 0.8 & 1.2 & & & & & Nepheline & 3.0461 & 18 \\
\hline \multirow[t]{2}{*}{3.002} & & 0.6 & 0.4 & & & & & Nepheline & 3.0059 & 100 \\
\hline & & & & & & & & Nepheline & 2.8864 & 35 \\
\hline 2.8274 & & 5.6 & 11.8 & 2.8379 & & 4.5 & 10.2 & Halite & 2.821 & 100 \\
\hline 2.8083 & -0.0013 & 8.9 & 13.5 & 2.8172 & -0.0102 & 8.9 & 10.8 & Sodalite & 2.807 & 8 \\
\hline 2.6954 & & 0.6 & 0.4 & & & & & & 2.70 & \\
\hline \multirow[t]{4}{*}{2.5617} & 0.0013 & 18.3 & 20.1 & 2.5703 & -0.0073 & 20.8 & 20.4 & Sodalite & 2.563 & 16 \\
\hline & & & & & & & & & 2.54 & \\
\hline & & & & & & & & Nepheline & 2.5000 & 14 \\
\hline & & & & & & & & Nepheline & 2.4007 & 10 \\
\hline \multirow[t]{2}{*}{2.3721} & 0.0009 & 19.1 & 20.8 & 2.3792 & -0.0062 & 19.7 & 19.8 & Sodalite & 2.373 & 16 \\
\hline & & & & & & & & Nepheline & 2.3395 & 35 \\
\hline
\end{tabular}


Table 22. (continued)

\begin{tabular}{|c|c|c|c|c|c|c|c|c|c|c|}
\hline \multicolumn{4}{|c|}{ Analysis 4} & \multicolumn{4}{|c|}{ Analysis 5} & \multicolumn{3}{|c|}{ Reference phase } \\
\hline \multirow[t]{2}{*}{$d(\AA)$} & Peak shift & $\begin{array}{c}\text { I\% peak } \\
\text { area }\end{array}$ & $\begin{array}{c}\text { I\% peak } \\
\text { height }\end{array}$ & $d(\AA \AA)$ & Peak shift & $\begin{array}{c}1 \% \text { peak } \\
\text { area }\end{array}$ & $\begin{array}{c}1 \% \text { peak } \\
\text { height }\end{array}$ & ID & $d(\AA)$ & $\begin{array}{c}1 \% \text { peak } \\
\text { height }\end{array}$ \\
\hline & & & & & & & & Nepheline & 2.3074 & 25 \\
\hline 2.2867 & & 0.8 & 0.5 & & & & & & 2.289 & \\
\hline \multirow[t]{4}{*}{2.2171} & 0.0019 & 1.0 & 1.2 & 2.2244 & -0.0054 & 1.3 & 1.0 & Sodalite & 2.219 & 1 \\
\hline & & & & & & & & Nepheline & 2.163 & 5 \\
\hline & & & & & & & & Nepheline & 2.1188 & 7 \\
\hline & & & & & & & & Nepheline & 2.0938 & 5 \\
\hline \multirow[t]{2}{*}{2.0924} & 0.0006 & 27.0 & 31.7 & 2.097 & -0.004 & 28.7 & 30.1 & Sodalite & 2.093 & 20 \\
\hline & & & & 2.078 & & 0.4 & 0.2 & & 2.074 & \\
\hline 2.0635 & & 0.5 & 0.4 & & & & & & 2.064 & \\
\hline 1.9968 & & 2.5 & 4.8 & 2.0044 & & 2.6 & 3.4 & Halite & 1.994 & 55 \\
\hline \multirow[t]{2}{*}{1.9851} & $-1 \mathrm{E}-04$ & 5.0 & 5.8 & 1.9886 & -0.0036 & 5.1 & 4.8 & Sodalite & 1.985 & 3 \\
\hline & & & & & & & & Nepheline & 1.9313 & 6 \\
\hline \multirow[t]{2}{*}{1.8916} & 0.0014 & 3.6 & 3.7 & 1.8959 & -0.0029 & 4.1 & 4.1 & Sodalite & 1.893 & 3 \\
\hline & & & & & & & & Nepheline & 1.8411 & 2 \\
\hline \multirow[t]{2}{*}{1.8099} & 0.0023 & 2.9 & 3.8 & 1.8144 & -0.0022 & 3.8 & 3.4 & Sodalite & 1.8122 & 2 \\
\hline & & & & & & & & Nepheline & 1.7923 & 5 \\
\hline 1.7397 & 0.0016 & 3.4 & 3.9 & 1.7434 & -0.0021 & 3.2 & 3.1 & Sodalite & 1.7413 & 2 \\
\hline \multirow[t]{3}{*}{1.7202} & & 0.6 & 0.3 & & & & & & 1.72 & \\
\hline & & & & & & & & Nepheline & 1.6942 & 5 \\
\hline & & & & & & & & Nepheline & 1.6346 & 6 \\
\hline 1.6338 & & 0.9 & 0.7 & 1.6338 & & 0.6 & 1.2 & Halite & 1.628 & 15 \\
\hline \multirow[t]{3}{*}{1.619} & 0.002 & 2.6 & 3.4 & 1.6221 & -0.0011 & 2.7 & 2.8 & Sodalite & 1.621 & 2 \\
\hline & & & & & & & & Nepheline & 1.615 & 8 \\
\hline & & & & & & & & Nepheline & 1.6002 & 4 \\
\hline \multirow[t]{2}{*}{1.5681} & 0.0015 & 9.7 & 12.5 & 1.5701 & -0.0005 & 10.1 & 11.6 & Sodalite & 1.5696 & 5 \\
\hline & & & & & & & & Nepheline & 1.5614 & 14 \\
\hline 1.5208 & 0.0019 & 4.5 & 6.3 & 1.5235 & -0.0008 & 5.3 & 5.9 & Sodalite & 1.5227 & 3 \\
\hline \multirow[t]{4}{*}{1.478} & 0.0017 & 7.1 & 10.0 & 1.4801 & -0.0004 & 8.6 & 9.2 & Sodalite & 1.4797 & 4 \\
\hline & & & & 1.4746 & & 0.6 & 0.3 & & 1.474 & \\
\hline & & & & 1.4674 & & 0.4 & 0.2 & Nepheline & 1.4687 & 5 \\
\hline & & & & 1.4629 & & 0.6 & 0.4 & & 1.463 & \\
\hline
\end{tabular}


Table 23. Summary of relative XRD peak heights and peak areas for replicate analyses of source material PC10402, in percent

\begin{tabular}{|c|c|c|c|c|c|c|c|c|c|c|c|c|}
\hline \multirow{2}{*}{$d$-spacing, $\AA$} & \multicolumn{6}{|c|}{ I\% peak height } & \multicolumn{6}{|c|}{$1 \%$ peak area } \\
\hline & Analysis 1 & Analysis 2 & Analysis 3 & Analysis 4 & Analysis 5 & Mean $\pm 2 s^{b}$ & Analysis 1 & Analysis 2 & Analysis 3 & Analysis 4 & Analysis 5 & Mean $\pm 2 s$ \\
\hline \multicolumn{13}{|c|}{ Halite } \\
\hline 3.26 & 1.0 & 1.9 & nd & nd & nd & $0.6 \pm 1.7$ & 1.0 & 0.9 & nd & nd & nd & $0.4 \pm 1.0$ \\
\hline 2.821 & 17.5 & 9.6 & 10.2 & 11.8 & 10.2 & $11.9 \pm 6.5$ & 5.6 & 6.1 & 5.6 & 5.6 & 4.5 & $5.5 \pm 1.2$ \\
\hline 1.994 & 6.0 & 4.9 & 7.1 & 4.8 & 3.4 & $5.2 \pm 2.8$ & 2.4 & 2.3 & 2.6 & 2.5 & 2.6 & $2.5 \pm 0.3$ \\
\hline 1.628 & 1.1 & 2.2 & 2.2 & 0.7 & 1.2 & $1.5 \pm 1.4$ & 0.6 & 0.8 & 0.7 & 0.9 & 0.6 & $0.7 \pm 0.3$ \\
\hline 1.41 & nd & nd & nd & nd & nd & 0 & nd & nd & nd & nd & nd & 0 \\
\hline \multicolumn{13}{|c|}{ Sodalite } \\
\hline 6.28 & 24.7 & 27.3 & 26.5 & 26.6 & 31.4 & $27.3 \pm 5.0$ & 23.8 & 26.9 & 25.8 & 23.9 & 27.0 & $25.5 \pm 3.2$ \\
\hline 3.624 & 100 & 100 & 100 & 100 & 100 & $100 \pm 0$ & 100 & 100 & 100 & 100 & 100 & $100 \pm 0$ \\
\hline 2.563 & 19.4 & 19.2 & 20.0 & 20.1 & 20.4 & $19.8 \pm 1.0$ & 18.4 & 18.5 & 18.2 & 18.3 & 20.8 & $18.8 \pm 2.2$ \\
\hline 2.373 & 20.5 & 20.5 & 20.2 & 20.8 & 19.8 & $20.4 \pm 0.8$ & 18.6 & 18.9 & 18.3 & 19.1 & 19.7 & $18.9 \pm 1.1$ \\
\hline 2.093 & 30.9 & 31.0 & 31.0 & 31.7 & 30.1 & $30.9 \pm 1.1$ & 28.2 & 27.2 & 25.6 & 27.0 & 28.7 & $27.3 \pm 2.4$ \\
\hline \multicolumn{13}{|c|}{ Nepheline } \\
\hline 4.3335 & nd & nd & nd & nd & nd & 0 & nd & nd & nd & nd & nd & 0 \\
\hline 4.1766 & nd & nd & nd & nd & nd & 0 & nd & nd & nd & nd & nd & 0 \\
\hline 3.8438 & nd & nd & nd & nd & nd & 0 & nd & nd & nd & nd & nd & 0 \\
\hline 3.2731 & nd & nd & nd & nd & nd & 0 & nd & nd & nd & nd & nd & 0 \\
\hline 3.0059 & nd & $\mathrm{nd}$ & nd & nd & nd & 0 & nd & nd & nd & nd & nd & 0 \\
\hline 2.8864 & nd & nd & nd & nd & nd & 0 & nd & nd & nd & nd & nd & 0 \\
\hline 2.3395 & nd & nd & nd & nd & nd & 0 & nd & nd & nd & nd & nd & 0 \\
\hline
\end{tabular}

a "nd" indicates that a quantifiable peak was not detected at this $d$-spacing.

${ }^{\mathrm{b}}$ Mean and standard deviation for 5 analyses; nd assigned value of 0 . 
Table 24. Results of XRD analyses of short-term heat-treated CWF materials heated at $600{ }^{\circ} \mathrm{C}$

\begin{tabular}{|c|c|c|c|c|c|c|c|c|c|c|c|c|c|c|}
\hline \multicolumn{3}{|c|}{$600^{\circ} \mathrm{C} 4$ hours } & \multicolumn{3}{|c|}{$600^{\circ} \mathrm{C} 28$ hours } & \multicolumn{3}{|c|}{$600^{\circ} \mathrm{C} 52$ hours } & \multicolumn{3}{|c|}{$600^{\circ} \mathrm{C} 100$ hours } & \multicolumn{3}{|c|}{ Reference phase } \\
\hline$d(\AA \AA)$ & $\begin{array}{c}1 \% \text { peak } \\
\text { area }\end{array}$ & $\begin{array}{c}1 \% \text { peak } \\
\text { height }\end{array}$ & $d(\AA)$ & $\begin{array}{c}1 \% \text { peak } \\
\text { area }\end{array}$ & $\begin{array}{c}1 \% \text { peak } \\
\text { height }\end{array}$ & $d(\AA \AA)$ & $\begin{array}{c}1 \% \text { peak } \\
\text { area }\end{array}$ & $\begin{array}{c}1 \% \text { peak } \\
\text { height }\end{array}$ & $d(\AA)$ & $\begin{array}{c}1 \% \text { peak } \\
\text { area }\end{array}$ & $\begin{array}{c}1 \% \text { peak } \\
\text { height }\end{array}$ & ID & $d(\AA)$ & $\begin{array}{c}1 \% \text { peak } \\
\text { height }\end{array}$ \\
\hline & & & & & & & & & & & & & 7.87 & \\
\hline & & & & & & & & & & & & & 7.38 & \\
\hline & & & & & & & & & & & & & 6.95 & \\
\hline & & & & & & & & & & & & & 6.90 & \\
\hline & & & & & & & & & & & & & 6.78 & \\
\hline 6.322 & 25.7 & 25.5 & 6.304 & 26.1 & 26.3 & 6.312 & 26.7 & 28.3 & 6.328 & 25.3 & 26.5 & Sodalite & 6.28 & 40 \\
\hline & & & & & & & & & & & & & 5.76 & \\
\hline & & & & & & 5.587 & 0.5 & 1.8 & & & & & 5.55 & \\
\hline & & & 5.485 & 0.1 & 1.6 & 5.499 & 0.2 & 1.8 & & & & & 5.47 & \\
\hline & & & & & & & & & & & & & 5.40 & \\
\hline & & & 5.324 & 0.3 & 1.7 & & & & & & & & 5.31 & \\
\hline & & & 5.105 & 0.7 & 1.9 & & & & 5.174 & 0.4 & 2.0 & & 5.09 & \\
\hline & & & & & & & & & 4.903 & 0.5 & 2.5 & Nepheline & 5.0058 & 10 \\
\hline & & & & & & & & & & & & & 4.86 & \\
\hline & & & & & & & & & & & & & 4.72 & \\
\hline & & & & & & & & & 4.770 & 0.5 & 2.6 & & 4.75 & \\
\hline & & & & & & & & & & & & & 4.66 & \\
\hline & & & 4.627 & 0.4 & 2.2 & & & & & & & & 4.62 & \\
\hline & & & & & & & & & & & & & 4.53 & \\
\hline 4.458 & 6.5 & 7.1 & 4.453 & 6.8 & 8.7 & 4.457 & 6.6 & 8.9 & 4.458 & 7.6 & 9.7 & Sodalite & 4.44 & 5 \\
\hline & & & & & & 4.368 & 0.4 & 2.7 & & & & & 4.20 & \\
\hline & & & & & & & & & & & & Nepheline & 4.3335 & 35 \\
\hline & & & 4.262 & 0.3 & 2.6 & & & & & & & & 4.25 & \\
\hline & & & 4.201 & 0.5 & 2.7 & & & & & & & & 4.19 & \\
\hline & & & & & & & & & & & & Nepheline & 4.1766 & 80 \\
\hline & & & 4.135 & 0.3 & 2.7 & & & & & & & & 4.12 & \\
\hline & & & & & & & & & & & & & 4.08 & \\
\hline 3.994 & 1.2 & 1.3 & 3.979 & 1.3 & 3.6 & 3.977 & 1.0 & 3.8 & 3.983 & 1.2 & 4.2 & Sodalite & 3.97 & 1 \\
\hline & & & 3.934 & 0.3 & 3.0 & & & & & & & & 3.92 & \\
\hline 3.878 & 0.3 & 0.5 & & & & 3.906 & 0.1 & 2.9 & & & & & 3.9 & \\
\hline & & & & & & & & & & & & Nepheline & 3.8438 & 100 \\
\hline & & & 3.814 & 0.2 & 2.9 & 3.800 & 0.4 & 3.1 & & & & & 3.80 & \\
\hline & & & & & & & & & & & & Nepheline & 3.7614 & 2 \\
\hline & & & & & & & & & & & & & 3.70 & \\
\hline 3.636 & 100 & 100 & 3.630 & 100 & 100 & 3.633 & 100 & 100 & 3.633 & 100 & 100 & Sodalite & 3.624 & 100 \\
\hline & & & & & & & & & & & & & 3.58 & \\
\hline
\end{tabular}


Table 24. (continued)

\begin{tabular}{|c|c|c|c|c|c|c|c|c|c|c|c|c|c|c|}
\hline \multicolumn{3}{|c|}{$600^{\circ} \mathrm{C} 4$ hours } & \multicolumn{3}{|c|}{$600^{\circ} \mathrm{C} 28$ hours } & \multicolumn{3}{|c|}{$600^{\circ} \mathrm{C} 52$ hours } & \multicolumn{3}{|c|}{$600^{\circ} \mathrm{C} 100$ hours } & \multicolumn{3}{|c|}{ Reference phase } \\
\hline$d(\AA)$ & $\begin{array}{c}\% \text { peak } \\
\text { area } \\
\end{array}$ & $\begin{array}{c}\text { I\% peak } \\
\text { height }\end{array}$ & $d(\AA)$ & $\begin{array}{c}\% \text { peak } \\
\text { area }\end{array}$ & $\begin{array}{c}\text { I\% peak } \\
\text { height }\end{array}$ & $d(\AA)$ & $\begin{array}{c}\% \text { peak } \\
\text { area } \\
\end{array}$ & $\begin{array}{c}\% \text { peak } \\
\text { height }\end{array}$ & $d(\AA)$ & $\begin{array}{c}1 \% \text { peak } \\
\text { area } \\
\end{array}$ & $\begin{array}{c}\text { I\% peak } \\
\text { height }\end{array}$ & ID & $d(\AA \AA)$ & $\begin{array}{c}\% \text { peak } \\
\text { height }\end{array}$ \\
\hline & & & & & & & & & 3.537 & 0.2 & 3.9 & & 3.53 & \\
\hline & & & & & & 3.445 & 0.4 & 3.4 & 3.462 & 0.1 & 3.5 & & 3.40 & \\
\hline & & & & & & 3.400 & 0.2 & 3.3 & & & & & 3.38 & \\
\hline & & & 3.342 & 0.4 & 3.0 & & & & & & & & 3.34 & \\
\hline & & & 3.324 & 0.4 & 3.2 & 3.339 & 0.4 & 3.1 & 3.305 & 0.5 & 3.7 & & 3.31 & \\
\hline & & & & & & & & & & & & & 3.30 & \\
\hline & & & & & & & & & & & & Nepheline & 3.2731 & 70 \\
\hline 3.271 & 0.7 & 0.8 & 3.263 & 1.3 & 3.2 & 3.274 & 1.5 & 3.6 & 3.270 & 0.3 & 3.8 & Halite & 3.26 & 13 \\
\hline & & & 3.152 & 0.9 & 2.9 & 3.162 & 0.6 & 3.0 & & & & & 3.15 & \\
\hline & & & & & & & & & & & & & 3.12 & \\
\hline & & & & & & & & & & & & & 3.10 & \\
\hline & & & & & & & & & & & & & 3.07 & \\
\hline & & & & & & & & & & & & Nepheline & 3.0461 & 18 \\
\hline & & & & & & & & & & & & & 3.03 & \\
\hline & & & & & & & & & & & & & 3.01 & \\
\hline & & & & & & & & & 3.008 & 0.5 & 3.2 & Nepheline & 3.0059 & 100 \\
\hline & & & 2.956 & 0.4 & 2.5 & & & & & & & & 2.95 & \\
\hline & & & & & & & & & & & & & 2.90 & \\
\hline & & & & & & & & & & & & Nepheline & 2.8864 & 35 \\
\hline & & & & & & & & & 2.865 & 0.5 & 3.0 & & 2.85 & \\
\hline 2.831 & 6.3 & 4.8 & 2.831 & 11.8 & 6.1 & 2.831 & 11.7 & 5.9 & 2.831 & 8.7 & 8.1 & Halite & 2.821 & 100 \\
\hline 2.812 & 10.9 & 8.7 & 2.810 & 9.3 & 10.1 & 2.812 & 13.0 & 9.6 & 2.810 & 14.8 & 10.6 & Sodalite & 2.807 & 8 \\
\hline & & & & & & & & & & & & & 2.78 & \\
\hline & & & 2.729 & 0.2 & 2.0 & 2.740 & 0.1 & 2.2 & & & & & 2.73 & \\
\hline & & & 2.704 & 0.2 & 1.9 & & & & & & & & 2.70 & \\
\hline & & & & & & & & & 2.680 & 0.2 & 2.2 & & 2.68 & \\
\hline & & & 2.663 & 0.3 & 2.1 & & & & 2.652 & 0.1 & 2.1 & & 2.65 & \\
\hline & & & 2.604 & 0.2 & 1.8 & & & & & & & & 2.60 & \\
\hline 2.567 & 20.0 & 19.0 & 2.564 & 19.7 & 19.6 & 2.566 & 19.6 & 18.9 & 2.566 & 20.1 & 21.4 & Sodalite & 2.563 & 16 \\
\hline & & & & & & & & & & & & & 2.54 & \\
\hline & & & & & & & & & & & & Nepheline & 2.5000 & 14 \\
\hline & & & & & & & & & & & & & 2.49 & \\
\hline & & & & & & & & & & & & & 2.45 & \\
\hline & & & & & & 2.404 & 0.2 & 1.6 & & & & Nepheline & 2.4007 & 10 \\
\hline 2.376 & 21.4 & 19.3 & 2.373 & 20.7 & 20.2 & 2.374 & 19.3 & 18.5 & 2.376 & 20.4 & 20.0 & Sodalite & 2.373 & 16 \\
\hline & & & & & & & & & & & & Nepheline & 2.3395 & 35 \\
\hline
\end{tabular}


Table 24. (continued)

\begin{tabular}{|c|c|c|c|c|c|c|c|c|c|c|c|c|c|c|}
\hline \multicolumn{3}{|c|}{$600^{\circ} \mathrm{C} 4$ hours } & \multicolumn{3}{|c|}{$600^{\circ} \mathrm{C} 28$ hours } & \multicolumn{3}{|c|}{$600^{\circ} \mathrm{C} 52$ hours } & \multicolumn{3}{|c|}{$600^{\circ} \mathrm{C} 100$ hours } & \multicolumn{3}{|c|}{ Reference phase } \\
\hline$d(\AA)$ & $\begin{array}{l}\text { I\% peak } \\
\text { area }\end{array}$ & $\begin{array}{c}1 \% \text { peak } \\
\text { height }\end{array}$ & $d(\AA)$ & $\begin{array}{c}1 \% \text { peak } \\
\text { area }\end{array}$ & $\begin{array}{c}1 \% \text { peak } \\
\text { height }\end{array}$ & $d(\AA)$ & $\begin{array}{c}1 \% \text { peak } \\
\text { area }\end{array}$ & $\begin{array}{c}\text { I\% peak } \\
\text { height }\end{array}$ & $d(\AA)$ & $\begin{array}{c}1 \% \text { peak } \\
\text { area }\end{array}$ & $\begin{array}{c}\text { I\% peak } \\
\text { height }\end{array}$ & ID & $d(\AA)$ & $\begin{array}{c}\text { I\% peak } \\
\text { height }\end{array}$ \\
\hline & & & & & & 2.317 & 0.4 & 1.6 & & & & & 2.31 & \\
\hline & & & & & & 2.305 & 0.7 & 1.6 & & & & Nepheline & 2.3074 & 25 \\
\hline & & & & & & 2.291 & 0.2 & 1.5 & & & & & 2.29 & \\
\hline & & & & & & & & & & & & & 2.26 & \\
\hline 2.222 & 1.3 & 1.1 & 2.220 & 1.8 & 2.3 & 2.220 & 1.4 & 2.4 & 2.220 & 1.0 & 2.5 & Sodalite & 2.219 & 1 \\
\hline & & & & & & & & & & & & Nepheline & 2.163 & \\
\hline & & & & & & & & & & & & Nepheline & 2.1188 & \\
\hline & & & & & & & & & & & & Nepheline & 2.0938 & 5 \\
\hline 2.094 & 32.0 & 26.8 & 2.092 & 31 & 27.7 & 2.093 & 29.6 & 24.2 & 2.093 & 30.6 & 28.6 & Sodalite & 2.093 & 20 \\
\hline 1.999 & 5.1 & 2.1 & 2.000 & 3.1 & 3.0 & 2.000 & 4.5 & 3.5 & 1.999 & 4.6 & 3.8 & Halite & 1.994 & 55 \\
\hline 1.986 & 6.0 & 4.2 & 1.985 & 7 & 4.9 & 1.986 & 5.7 & 5.2 & 1.985 & 6.6 & 5.4 & Sodalite & 1.985 & 3 \\
\hline & & & & & & & & & 1.967 & 0.2 & 1.6 & & 1.97 & \\
\hline & & & & & & & & & 1.957 & 0.3 & 1.7 & & 1.96 & \\
\hline 1.894 & 4.4 & 3.5 & 1.937 & 0.2 & 1.4 & & & & & & & Nepheline & 1.9313 & 6 \\
\hline & & & 1.892 & 4.3 & 4.4 & 1.892 & 3.4 & 4.2 & 1.893 & 4.4 & 5.1 & Sodalite & 1.893 & 3 \\
\hline & & & & & & & & & & & & Nepheline & 1.8411 & 2 \\
\hline 1.813 & 4.2 & 3.3 & 1.812 & 3.6 & 3.7 & 1.812 & 3.4 & 3.4 & 1.812 & 3.7 & 4.2 & Sodalite & 1.8122 & 2 \\
\hline & & & & & & & & & & & & Nepheline & 1.7923 & 5 \\
\hline 1.742 & 4.0 & 3.1 & 1.741 & 4.2 & 4.1 & 1.741 & 3.4 & 3.8 & 1.741 & 3.7 & 4.3 & Sodalite & 1.7413 & 2 \\
\hline & & & & & & & & & & & & & 1.72 & \\
\hline & & & & & & & & & & & & Nepheline & 1.6942 & 5 \\
\hline & & & & & & & & & & & & & 1.67 & \\
\hline & & & 1.646 & 0.1 & 1.3 & & & & & & & & 1.65 & \\
\hline & & & & & & & & & & & & Nepheline & 1.6346 & 6 \\
\hline 1.631 & 1.2 & 0.8 & 1.633 & 1.5 & 1.5 & 1.632 & 2.5 & 1.8 & 1.629 & 2.4 & 1.8 & Halite & 1.628 & 15 \\
\hline 1.621 & 3.5 & 2.6 & 1.620 & 4.0 & 3.2 & 1.620 & 3.4 & 3.3 & 1.621 & 3.8 & 3.7 & Sodalite & 1.621 & 2 \\
\hline & & & & & & 1.569 & 11.0 & 8.9 & 1.590 & 0.3 & 1.6 & Nepheline & 1.615 & 8 \\
\hline & & & & & & & & & & & & Nepheline & 1.6002 & 4 \\
\hline 1.569 & 12.4 & 9.0 & 1.568 & 11.6 & 9.4 & 1.569 & 11.0 & 8.9 & 1.569 & 12.2 & 10.5 & Sodalite & 1.5696 & 5 \\
\hline & & & & & & & & & & & & Nepheline & 1.5614 & 14 \\
\hline 1.522 & 6.3 & 4.9 & 1.521 & 6.3 & 5.0 & 1.522 & 5.8 & 5.1 & 1.521 & 6.3 & 5.4 & Sodalite & 1.5227 & 3 \\
\hline & & & 1.507 & 0.2 & 1.2 & & & & & & & & 1.51 & \\
\hline 1.479 & 10.0 & 7.5 & 1.478 & 9.6 & 7.2 & 1.479 & 8.2 & 7.1 & 1.479 & 9.4 & 8.3 & Sodalite & 1.4797 & 4 \\
\hline & & & & & & & & & & & & Nepheline & 1.4687 & 5 \\
\hline & & & & & & & & & & & & Nepheline & 1.4555 & 3 \\
\hline 1.440 & 10.3 & 7.0 & 1.439 & 10.1 & 7.5 & 1.439 & 8.7 & 7.3 & 1.439 & 10.4 & 9.1 & Sodalite & 1.4404 & 5 \\
\hline
\end{tabular}


Table 24. (continued)

\begin{tabular}{|c|c|c|c|c|c|c|c|c|c|c|c|c|c|c|}
\hline \multicolumn{3}{|c|}{$600^{\circ} \mathrm{C} 4$ hours } & \multicolumn{3}{|c|}{$600^{\circ} \mathrm{C} 28$ hours } & \multicolumn{3}{|c|}{$600^{\circ} \mathrm{C} 52$ hours } & \multicolumn{3}{|c|}{$600^{\circ} \mathrm{C} 100$ hours } & \multicolumn{3}{|c|}{ Reference phase } \\
\hline$d(\AA)$ & $\begin{array}{c}1 \% \text { peak } \\
\text { area }\end{array}$ & $\begin{array}{c}1 \% \text { peak } \\
\text { height }\end{array}$ & $d(\AA)$ & $\begin{array}{c}1 \% \text { peak } \\
\text { area }\end{array}$ & $\begin{array}{c}1 \% \text { peak } \\
\text { height }\end{array}$ & $d(\AA)$ & $\begin{array}{c}\text { I\% peak } \\
\text { area }\end{array}$ & $\begin{array}{c}\text { I\% peak } \\
\text { height }\end{array}$ & $d(\AA)$ & $\begin{array}{c}1 \% \text { peak } \\
\text { area }\end{array}$ & $\begin{array}{c}1 \% \text { peak } \\
\text { height }\end{array}$ & ID & $d(\AA)$ & $\begin{array}{c}1 \% \text { peak } \\
\text { height }\end{array}$ \\
\hline & & & & & & & & & & & & Nepheline & 1.4282 & 7 \\
\hline & & & & & & & & & & & & Halite & 1.41 & 6 \\
\hline 1.403 & 0.5 & 0.6 & 1.402 & 0.8 & 1.7 & 1.403 & 0.5 & 1.7 & 1.402 & 1.4 & 1.7 & Sodalite & 1.4038 & 1 \\
\hline & & & & & & & & & & & & & 1.40 & \\
\hline & & & & & & & & & 1.399 & 1.2 & 1.5 & Nepheline & 1.3865 & 6 \\
\hline 1.369 & 3.5 & 2.9 & 1.368 & 4.4 & 3.5 & 1.369 & 3.5 & 3.1 & 1.369 & 4.0 & 4.1 & Sodalite & 1.3699 & 6 \\
\hline 1.337 & 4.5 & 2.7 & 1.337 & 4.5 & 3.5 & 1.337 & 3.7 & 3.7 & 1.338 & 4.5 & 4.3 & Sodalite & 1.3385 & 2 \\
\hline & & & & & & 1.335 & 3.6 & 2.2 & & & & & 1.34 & \\
\hline 1.308 & 4.4 & 2.9 & 1.308 & 4.5 & 3.6 & 1.308 & 3.2 & 3.4 & 1.308 & 3.7 & 3.8 & Sodalite & 1.3091 & 2 \\
\hline & & & & & & 1.305 & 2.7 & 2 & & & & & 1.31 & \\
\hline 1.281 & 2.6 & 2.0 & 1.279 & 3.4 & 2.8 & 1.280 & 2.5 & 2.5 & 1.280 & 3.1 & 3.1 & Sodalite & 1.2814 & 2 \\
\hline & & & & & & & & & & & & Nepheline & 1.279 & 6 \\
\hline 1.263 & 0.8 & 0.6 & 1.264 & 0.6 & 1.4 & & & & 1.264 & 0.8 & 1.5 & Sodalite & 1.2684 & 1 \\
\hline & & & 1.251 & 0.2 & 1.0 & & & & & & & Sodalite & 1.2555 & 1 \\
\hline 1.231 & 0.8 & 0.5 & 1.229 & 0.8 & 1.2 & 1.229 & 0.6 & 1.2 & 1.230 & 0.9 & 1.6 & Nepheline & 1.2347 & 4 \\
\hline & & & & & & & & & & & & & 1.23 & \\
\hline 1.207 & 7.3 & 5.8 & 1.207 & 7.6 & 6.1 & 1.207 & 7.5 & 5.3 & 1.207 & 9.2 & 6.8 & Sodalite & 1.2081 & 3 \\
\hline
\end{tabular}


Table 25. Results of XRD analyses of short-term heat-treated CWF materials heated at $700{ }^{\circ} \mathrm{C}$

\begin{tabular}{|c|c|c|c|c|c|c|c|c|c|c|c|c|c|c|}
\hline \multicolumn{3}{|c|}{$700^{\circ} \mathrm{C} 4$ hours } & \multicolumn{3}{|c|}{$700^{\circ} \mathrm{C} 28$ hours } & \multicolumn{3}{|c|}{$700^{\circ} \mathrm{C} 52$ hours } & \multicolumn{3}{|c|}{$700^{\circ} \mathrm{C} 100$ hours } & \multicolumn{3}{|c|}{ Reference phase } \\
\hline$d(\AA)$ & $\begin{array}{c}I \% \text { peak } \\
\text { area }\end{array}$ & $\begin{array}{c}1 \% \text { peak } \\
\text { height }\end{array}$ & $d(\AA)$ & $\begin{array}{c}\text { I\% peak } \\
\text { area }\end{array}$ & $\begin{array}{c}1 \% \text { peak } \\
\text { height }\end{array}$ & $d(\AA)$ & $\begin{array}{c}1 \% \text { peak } \\
\text { area }\end{array}$ & $\begin{array}{c}1 \% \text { peak } \\
\text { height }\end{array}$ & $d(\AA \AA)$ & $\begin{array}{c}1 \% \text { peak } \\
\text { area }\end{array}$ & $\begin{array}{c}1 \% \text { peak } \\
\text { height }\end{array}$ & ID & $d(\AA)$ & $\begin{array}{c}\text { I\% peak } \\
\text { height }\end{array}$ \\
\hline & & & & & & & & & & & & & 7.87 & \\
\hline & & & & & & & & & & & & & 7.38 & \\
\hline & & & & & & & & & 7.028 & 0.2 & 1.5 & & 6.95 & \\
\hline & & & 6.927 & 0.2 & 1.5 & & & & & & & & 6.90 & \\
\hline & & & & & & & & & & & & & 6.78 & \\
\hline 6.319 & 26.5 & 25.9 & 6.311 & 27.2 & 25.2 & 6.321 & 24.1 & 22.8 & 6.348 & 26.0 & 26.7 & Sodalite & 6.28 & 40 \\
\hline & & & & & & & & & & & & & 5.76 & \\
\hline & & & & & & & & & 5.701 & 0.2 & 1.6 & & 5.55 & \\
\hline & & & & & & & & & & & & & 5.47 & \\
\hline & & & & & & & & & & & & & 5.40 & \\
\hline & & & & & & & & & & & & & 5.31 & \\
\hline & & & & & & & & & & & & & 5.09 & \\
\hline & & & & & & & & & & & & Nepheline & 5.0058 & 10 \\
\hline & & & & & & & & & & & & & 4.86 & \\
\hline & & & 4.726 & 0.1 & 2.0 & & & & & & & & 4.72 & \\
\hline & & & & & & & & & & & & & 4.75 & \\
\hline & & & 4.676 & 0.2 & 2.2 & & & & & & & & 4.66 & \\
\hline & & & & & & & & & & & & & 4.62 & \\
\hline & & & & & & & & & & & & & 4.53 & \\
\hline 4.454 & 6.5 & 6.7 & 4.449 & 7.1 & 8.9 & 4.458 & 6.7 & 7.6 & 4.471 & 7.3 & 8.9 & Sodalite & 4.44 & 5 \\
\hline & & & & & & & & & & & & & 4.20 & \\
\hline & & & & & & & & & & & & Nepheline & 4.3335 & 35 \\
\hline & & & & & & & & & & & & & 4.25 & \\
\hline & & & & & & & & & & & & & 4.19 & \\
\hline & & & & & & & & & & & & Nepheline & 4.1766 & 80 \\
\hline & & & 4.123 & 0.1 & 2.7 & & & & & & & & 4.12 & \\
\hline & & & & & & & & & & & & & 4.08 & \\
\hline 3.977 & 1.3 & 1.2 & 3.971 & 0.9 & 3.6 & 3.987 & 1.5 & 2.0 & 3.991 & 0.8 & 3 & Sodalite & 3.97 & 1 \\
\hline & & & & & & & & & & & & & 3.92 & \\
\hline & & & & & & & & & & & & & 3.9 & \\
\hline & & & & & & & & & 3.857 & 0.6 & 2.9 & Nepheline & 3.8438 & 100 \\
\hline & & & & & & & & & & & & & 3.80 & \\
\hline & & & & & & & & & & & & Nepheline & 3.7614 & 2 \\
\hline & & & & & & & & & & & & & 3.70 & \\
\hline 3.633 & 100 & 100 & 3.630 & 100 & 100 & 3.636 & 100 & 100 & 3.645 & 100 & 100 & Sodalite & 3.624 & 100 \\
\hline & & & & & & 3.590 & 1 & 2 & & & & & 3.58 & \\
\hline
\end{tabular}


Table 25. (continued)

\begin{tabular}{|c|c|c|c|c|c|c|c|c|c|c|c|c|c|c|}
\hline \multicolumn{3}{|c|}{$700^{\circ} \mathrm{C} 4$ hours } & \multicolumn{3}{|c|}{$700^{\circ} \mathrm{C} 28$ hours } & \multicolumn{3}{|c|}{$700^{\circ} \mathrm{C} 52$ hours } & \multicolumn{3}{|c|}{$700^{\circ} \mathrm{C} \quad 100$ hours } & \multicolumn{3}{|c|}{ Reference phase } \\
\hline$d(\AA)$ & $\begin{array}{c}1 \% \text { peak } \\
\text { area }\end{array}$ & $\begin{array}{c}\text { I\% peak } \\
\text { height }\end{array}$ & $d(\AA)$ & $\begin{array}{c}\text { I\% peak } \\
\text { area }\end{array}$ & $\begin{array}{c}\text { I\% peak } \\
\text { height }\end{array}$ & $d(\AA)$ & $\begin{array}{c}1 \% \text { peak } \\
\text { area }\end{array}$ & $\begin{array}{c}\text { I\% peak } \\
\text { height }\end{array}$ & $d(\AA)$ & $\begin{array}{c}\text { I\% peak } \\
\text { area }\end{array}$ & $\begin{array}{c}\text { I\% peak } \\
\text { height }\end{array}$ & ID & $d(\AA)$ & $\begin{array}{c}\text { I\% peak } \\
\text { height }\end{array}$ \\
\hline & & & & & & 3.530 & 0.2 & 1.5 & & & & & 3.53 & \\
\hline 3.447 & 0.4 & 0.4 & & & & & & & & & & & 3.40 & \\
\hline & & & & & & 3.346 & 0.3 & 1.4 & 3.386 & 0.6 & 2.9 & & 3.38 & \\
\hline & & & & & & & & & & & & & 3.34 & \\
\hline & & & & & & & & & & & & & 3.31 & \\
\hline & & & & & & & & & & & & & 3.30 & \\
\hline & & & & & & & & & & & & Nepheline & 3.2731 & 70 \\
\hline 3.273 & 0.6 & 0.6 & 3.266 & 0.5 & 3.2 & & & & 3.283 & 0.8 & 2.7 & Halite & 3.26 & 13 \\
\hline 3.110 & 0.3 & 0.5 & & & & 3.147 & 0.5 & 1.1 & & & & & 3.15 & \\
\hline & & & & & & & & & & & & & 3.12 & \\
\hline & & & & & & & & & & & & & 3.10 & \\
\hline & & & & & & & & & & & & & 3.07 & \\
\hline & & & & & & & & & & & & Nepheline & 3.0461 & 18 \\
\hline & & & & & & & & & & & & & 3.03 & \\
\hline & & & & & & & & & 3.023 & 0.3 & 2.1 & & 3.01 & \\
\hline & & & & & & & & & & & & Nepheline & 3.0059 & 100 \\
\hline & & & & & & & & & & & & & 2.95 & \\
\hline & & & & & & & & & & & & & 2.90 & \\
\hline & & & & & & & & & & & & Nepheline & 2.8864 & 35 \\
\hline & & & & & & & & & & & & & 2.85 & \\
\hline 2.831 & 11.4 & 4.3 & 2.829 & 4.9 & 5.8 & 2.833 & 8.0 & 4.1 & 2.839 & 6.6 & 4.6 & Halite & 2.821 & 100 \\
\hline 2.812 & 11.6 & 8.3 & 2.808 & 9.9 & 10.9 & 2.813 & 12.3 & 9.1 & 2.817 & 11.2 & 9.7 & Sodalite & 2.807 & 8 \\
\hline & & & 2.777 & 0.1 & 2.1 & & & & & & & & 2.78 & \\
\hline & & & & & & & & & & & & & 2.73 & \\
\hline & & & & & & & & & & & & & 2.70 & \\
\hline & & & & & & & & & & & & & 2.68 & \\
\hline & & & & & & 2.671 & 0.1 & 0.4 & & & & & 2.65 & \\
\hline & & & & & & & & & & & & & 2.60 & \\
\hline 2.566 & 19.6 & 17.7 & 2.563 & 20.8 & 20.0 & 2.567 & 19.9 & 20 & 2.569 & 20.1 & 18.4 & Sodalite & 2.563 & 16 \\
\hline & & & & & & & & & & & & & 2.54 & \\
\hline & & & & & & & & & & & & Nepheline & 2.5000 & 14 \\
\hline & & & & & & & & & & & & & 2.49 & \\
\hline & & & & & & 2.446 & 0.2 & 0.3 & & & & & 2.45 & \\
\hline & & & & & & & & & & & & Nepheline & 2.4007 & 10 \\
\hline 2.375 & 20.1 & 18.0 & 2.373 & 21.1 & 20.4 & 2.376 & 21 & 20.1 & 2.378 & 20.3 & 18.5 & Sodalite & 2.373 & 16 \\
\hline & & & & & & & & & & & & Nepheline & 2.3395 & 35 \\
\hline
\end{tabular}


Table 25. (continued)

\begin{tabular}{|c|c|c|c|c|c|c|c|c|c|c|c|c|c|c|}
\hline \multicolumn{3}{|c|}{$700^{\circ} \mathrm{C} 4$ hours } & \multicolumn{3}{|c|}{$700^{\circ} \mathrm{C} 28$ hours } & \multicolumn{3}{|c|}{$700^{\circ} \mathrm{C} 52$ hours } & \multicolumn{3}{|c|}{$700^{\circ} \mathrm{C} 100$ hours } & \multicolumn{3}{|c|}{ Reference phase } \\
\hline$d(\AA \AA)$ & $\begin{array}{c}\text { I\% peak } \\
\text { area }\end{array}$ & $\begin{array}{c}\text { I\% peak } \\
\text { height }\end{array}$ & $d(\AA)$ & $\begin{array}{c}\text { I\% peak } \\
\text { area }\end{array}$ & $\begin{array}{c}\text { I\% peak } \\
\text { height }\end{array}$ & $d(\AA)$ & $\begin{array}{c}\text { I\% peak } \\
\text { area }\end{array}$ & $\begin{array}{c}\text { I\% peak } \\
\text { height }\end{array}$ & $d(\AA)$ & $\begin{array}{c}\text { I\% peak } \\
\text { area }\end{array}$ & $\begin{array}{c}\text { I\% peak } \\
\text { height }\end{array}$ & ID & $d(\AA)$ & $\begin{array}{c}\text { I\% peak } \\
\text { height }\end{array}$ \\
\hline & & & & & & & & & & & & & 2.31 & \\
\hline & & & & & & & & & & & & Nepheline & 2.3074 & 25 \\
\hline & & & & & & & & & & & & & 2.29 & \\
\hline & & & & & & & & & & & & & 2.26 & \\
\hline 2.220 & 1.5 & 1.1 & 2.218 & 1.5 & 2.6 & 2.221 & 1.6 & 1.4 & 2.224 & 1.2 & 2.0 & Sodalite & 2.219 & 1 \\
\hline 2.194 & 0.2 & 0.3 & & & & & & & & & & Nepheline & 2.163 & \\
\hline & & & & & & & & & & & & Nepheline & 2.1188 & \\
\hline & & & & & & & & & & & & Nepheline & 2.0938 & 5 \\
\hline 2.093 & 30.4 & 26.1 & 2.092 & 32.1 & 28.7 & 2.094 & 30.3 & 30.0 & 2.096 & 31.2 & 26.1 & Sodalite & 2.093 & 20 \\
\hline 2.000 & 3.8 & 2.2 & 1.999 & 3.4 & 3.1 & 2.002 & 2.2 & 1.8 & 2.003 & 2.1 & 2.2 & Halite & 1.994 & 55 \\
\hline 1.985 & 5.0 & 4.3 & 1.984 & 5.7 & 5.6 & 1.986 & 4.6 & 4.6 & 1.988 & 5.1 & 4.9 & Sodalite & 1.985 & 3 \\
\hline & & & & & & & & & & & & & 1.97 & \\
\hline & & & & & & & & & & & & & 1.96 & \\
\hline & & & & & & & & & & & & Nepheline & 1.9313 & 6 \\
\hline 1.894 & 4.1 & 3 & 1.892 & 4.3 & 4.4 & 1.893 & 4.1 & 4.0 & 1.895 & 4.1 & 4.2 & Sodalite & 1.893 & 3 \\
\hline & & & & & & 1.837 & 0.3 & 0.3 & & & & Nepheline & 1.8411 & 2 \\
\hline 1.812 & 3.5 & 2.9 & 1.811 & 3.7 & 3.7 & 1.813 & 3.6 & 3.6 & 1.814 & 3.6 & 3.6 & Sodalite & 1.8122 & 2 \\
\hline & & & & & & 1.760 & 0.1 & 0.4 & & & & Nepheline & 1.7923 & 5 \\
\hline 1.741 & 4.0 & 3.0 & 1.740 & 4.1 & 4.4 & 1.741 & 4.1 & 3.8 & 1.742 & 4.2 & 3.6 & Sodalite & 1.7413 & 2 \\
\hline & & & & & & & & & & & & & 1.72 & \\
\hline & & & & & & 1.691 & 0.3 & 0.4 & 1.696 & 0.2 & 1.1 & Nepheline & 1.6942 & 5 \\
\hline & & & & & & 1.669 & 0.3 & 0.4 & & & & & 1.67 & \\
\hline & & & & & & & & & & & & & 1.65 & \\
\hline 1.634 & 1.0 & 0.6 & & & & & & & & & & Nepheline & 1.6346 & 6 \\
\hline & & & 1.631 & 0.9 & 1.7 & 1.634 & 1.0 & 0.8 & 1.632 & 0.7 & 1.2 & Halite & 1.628 & 15 \\
\hline 1.620 & 3.0 & 2.4 & 1.619 & 3.2 & 3.4 & 1.621 & 3.4 & 2.8 & 1.621 & 3.0 & 3.0 & Sodalite & 1.621 & 2 \\
\hline & & & & & & & & & & & & Nepheline & 1.615 & 8 \\
\hline & & & & & & & & & & & & Nepheline & 1.6002 & 4 \\
\hline 1.569 & 12.0 & 8.8 & 1.568 & 12.3 & 10.1 & 1.569 & 11.9 & 11.5 & 1.570 & 11.8 & 8.6 & Sodalite & 1.5696 & 5 \\
\hline & & & & & & & & & & & & Nepheline & 1.5614 & 14 \\
\hline 1.522 & 5.9 & 4.3 & 1.521 & 6.8 & 5.6 & 1.522 & 6.2 & 5.7 & 1.523 & 6.3 & 4.7 & Sodalite & 1.5227 & 3 \\
\hline & & & & & & & & & & & & & 1.51 & \\
\hline 1.479 & 9.1 & 6.5 & 1.478 & 11.3 & 7.9 & 1.479 & 9.6 & 8.6 & 1.479 & 9.6 & 7.1 & Sodalite & 1.4797 & 4 \\
\hline & & & & & & & & & & & & Nepheline & 1.4687 & 5 \\
\hline & & & & & & & & & & & & Nepheline & 1.4555 & 3 \\
\hline 1.440 & 10.1 & 7.0 & 1.439 & 11.1 & 8.3 & 1.440 & 10.6 & 9.6 & 1.440 & 10.0 & 7.4 & Sodalite & 1.4404 & 5 \\
\hline
\end{tabular}


Table 25. (continued)

\begin{tabular}{|c|c|c|c|c|c|c|c|c|c|c|c|c|c|c|}
\hline \multicolumn{3}{|c|}{$700^{\circ} \mathrm{C} 4$ hours } & \multicolumn{3}{|c|}{$700^{\circ} \mathrm{C} 28$ hours } & \multicolumn{3}{|c|}{$700^{\circ} \mathrm{C} 52$ hours } & \multicolumn{3}{|c|}{$700^{\circ} \mathrm{C} 100$ hours } & \multicolumn{3}{|c|}{ Reference phase } \\
\hline$d(\AA)$ & $\begin{array}{c}1 \% \text { peak } \\
\text { area }\end{array}$ & $\begin{array}{c}\text { I\% peak } \\
\text { height }\end{array}$ & $d(\AA)$ & $\begin{array}{c}\text { I\% peak } \\
\text { area }\end{array}$ & $\begin{array}{c}\text { I\% peak } \\
\text { height }\end{array}$ & $d(\AA ̊)$ & $\begin{array}{c}1 \% \text { peak } \\
\text { area }\end{array}$ & $\begin{array}{c}\text { I\% peak } \\
\text { height }\end{array}$ & $d(\AA \AA)$ & $\begin{array}{c}1 \% \text { peak } \\
\text { area }\end{array}$ & $\begin{array}{c}1 \% \text { peak } \\
\text { height }\end{array}$ & ID & $d(\AA ̊)$ & $\begin{array}{c}\text { I\% peak } \\
\text { height }\end{array}$ \\
\hline & & & & & & 1.433 & 0.4 & 0.4 & & & & Nepheline & 1.4282 & 7 \\
\hline 1.414 & 0.2 & 0.3 & & & & & & & & & & Halite & 1.41 & 6 \\
\hline 1.402 & 0.8 & 0.6 & 1.403 & 0.4 & 1.3 & 1.403 & 0.9 & 0.8 & 1.404 & 0.7 & 1.4 & Sodalite & 1.4038 & 1 \\
\hline & & & & & & & & & & & & & 1.40 & \\
\hline & & & & & & & & & & & & Nepheline & 1.3865 & 6 \\
\hline 1.369 & 3.6 & 2.9 & 1.368 & 3.7 & 4.0 & 1.369 & 4.1 & 3.8 & 1.370 & 4.0 & 3.3 & Sodalite & 1.3699 & 6 \\
\hline 1.338 & 4.2 & 2.7 & 1.336 & 4.8 & 3.8 & 1.338 & 4.6 & 3.8 & 1.338 & 3.6 & 3.6 & Sodalite & 1.3385 & 2 \\
\hline & & & & & & 1.333 & 0.7 & 0.6 & & & & & 1.34 & \\
\hline 1.307 & 3.5 & 2.6 & 1.307 & 3.5 & 3.7 & 1.308 & 4.4 & 4.2 & 1.308 & 3.7 & 3.3 & Sodalite & 1.3091 & 2 \\
\hline & & & & & & & & & & & & & 1.31 & \\
\hline 1.280 & 2.6 & 1.9 & 1.280 & 3.1 & 2.9 & 1.281 & 3.3 & 2.7 & 1.281 & 2.7 & 2.6 & Sodalite & 1.2814 & 2 \\
\hline & & & & & & & & & & & & Nepheline & 1.279 & 6 \\
\hline 1.264 & 0.9 & 0.6 & & & & & & & & & & Sodalite & 1.2684 & 1 \\
\hline & & & & & & & & & & & & Sodalite & 1.2555 & 1 \\
\hline & & & 1.229 & 0.5 & 1.3 & 1.230 & 0.9 & 0.7 & 1.230 & 0.6 & 1.1 & Nepheline & 1.2347 & 4 \\
\hline 1.230 & 0.4 & 0.4 & & & & 1.225 & 0.1 & 0.3 & & & & & 1.23 & \\
\hline 1.207 & 7.1 & 5.9 & 1.206 & 7.7 & 6.1 & 1.207 & 8.8 & 7.7 & 1.207 & 8.5 & 5.8 & Sodalite & 1.2081 & 3 \\
\hline
\end{tabular}


Table 26. Results of XRD analyses of short-term heat-treated CWF materials heated at $800{ }^{\circ} \mathrm{C}$

\begin{tabular}{|c|c|c|c|c|c|c|c|c|c|c|c|c|c|c|}
\hline \multicolumn{3}{|c|}{$800^{\circ} \mathrm{C} 4$ hours } & \multicolumn{3}{|c|}{$800^{\circ} \mathrm{C} 28$ hours } & \multicolumn{3}{|c|}{$800^{\circ} \mathrm{C} 52$ hours } & \multicolumn{3}{|c|}{$800^{\circ} \mathrm{C} 100$ hours } & \multicolumn{3}{|c|}{ Reference phase } \\
\hline$d(\AA \AA)$ & $\begin{array}{c}1 \% \text { peak } \\
\text { area }\end{array}$ & $\begin{array}{c}\text { I\% peak } \\
\text { height }\end{array}$ & $d(\AA)$ & $\begin{array}{c}\text { I\% peak } \\
\text { area }\end{array}$ & $\begin{array}{c}\text { I\% peak } \\
\text { height }\end{array}$ & $d(\AA)$ & $\begin{array}{c}1 \% \text { peak } \\
\text { area }\end{array}$ & $\begin{array}{c}\text { I\% peak } \\
\text { height }\end{array}$ & $d(\AA)$ & $\begin{array}{c}\text { I\% peak } \\
\text { area }\end{array}$ & $\begin{array}{c}\text { I\% peak } \\
\text { height }\end{array}$ & ID & $d(\AA)$ & $\begin{array}{c}\text { I\% peak } \\
\text { height }\end{array}$ \\
\hline 6.3295 & 26.2 & 26.6 & & & & & & & & & & & 7.87 & \\
\hline & & & & & & & & & & & & & 7.38 & \\
\hline & & & & & & & & & & & & & 6.95 & \\
\hline & & & & & & & & & & & & & 6.90 & \\
\hline & & & & & & & & & & & & & 6.78 & \\
\hline 6.330 & 26.2 & 26.6 & 6.330 & 27.7 & 26.9 & 6.329 & 26.3 & 30.4 & 6.331 & 26.5 & 29.1 & Sodalite & 6.28 & 40 \\
\hline & & & & & & 5.811 & 0.1 & 1.8 & & & & & 5.76 & \\
\hline & & & & & & & & & & & & & 5.55 & \\
\hline & & & & & & 5.546 & 0.1 & 1.8 & & & & & 5.47 & \\
\hline & & & & & & & & & & & & & 5.40 & \\
\hline & & & & & & & & & & & & & 5.31 & \\
\hline 5.136 & 0.2 & 0.4 & 5.146 & 0.2 & 1.7 & & & & & & & & 5.09 & \\
\hline & & & 5.073 & 0.1 & 1.8 & 5.017 & 0.3 & 2.2 & & & & Nepheline & 5.0058 & 10 \\
\hline & & & & & & & & & & & & & 4.86 & \\
\hline & & & & & & & & & & & & & 4.72 & \\
\hline & & & 4.900 & 0.1 & 1.8 & & & & & & & & 4.75 & \\
\hline & & & 4.849 & 0.1 & 2 & & & & & & & & 4.66 & \\
\hline & & & 4.631 & 0.1 & 2 & & & & & & & & 4.62 & \\
\hline & & & & & & & & & & & & & 4.53 & \\
\hline 4.462 & 7.1 & 7.3 & 4.463 & 7.0 & 9.0 & 4.462 & 7.2 & 9.7 & 4.466 & 7.6 & 9.2 & Sodalite & 4.44 & 5 \\
\hline & & & & & & & & & & & & & 4.20 & \\
\hline & & & & & & 4.349 & 0.3 & 2.7 & 4.346 & 0.3 & 2.8 & Nepheline & 4.3335 & 35 \\
\hline & & & & & & 4.199 & 0.6 & 2.9 & & & & & 4.25 & \\
\hline & & & 4.196 & 0.4 & 2.7 & & & & 4.211 & 1.2 & 3.2 & & 4.19 & \\
\hline & & & & & & & & & & & & Nepheline & 4.1766 & 80 \\
\hline & & & & & & & & & & & & & 4.12 & \\
\hline & & & 4.111 & 0.6 & 2.6 & & & & 4.108 & 0.6 & 2.8 & & 4.08 & \\
\hline 3.987 & 0.9 & 1.4 & 3.980 & 1.5 & 3.4 & 3.987 & 1.1 & 3.8 & 3.993 & 1.0 & 3.8 & Sodalite & 3.97 & 1 \\
\hline & & & & & & & & & & & & & 3.92 & \\
\hline & & & & & & 3.890 & 0.2 & 3.2 & & & & & 3.9 & \\
\hline & & & 3.865 & 0.3 & 3.1 & 3.865 & 0.7 & 3.4 & 3.858 & 0.7 & 3.5 & Nepheline & 3.8438 & 100 \\
\hline & & & & & & 3.782 & 0.3 & 3.3 & & & & & 3.80 & \\
\hline & & & & & & & & & & & & Nepheline & 3.7614 & 2 \\
\hline & & & & & & & & & & & & & 3.70 & \\
\hline
\end{tabular}


Table 26. (continued)

\begin{tabular}{|c|c|c|c|c|c|c|c|c|c|c|c|c|c|c|}
\hline \multicolumn{3}{|c|}{$800^{\circ} \mathrm{C} 4$ hours } & \multicolumn{3}{|c|}{$800^{\circ} \mathrm{C} 28$ hours } & \multicolumn{3}{|c|}{$800^{\circ} \mathrm{C} 52$ hours } & \multicolumn{3}{|c|}{$800^{\circ} \mathrm{C} 100$ hours } & \multicolumn{3}{|c|}{ Reference phase } \\
\hline$d(\AA)$ & $\begin{array}{c}\text { I\% peak } \\
\text { area }\end{array}$ & $\begin{array}{c}\text { I\% peak } \\
\text { height }\end{array}$ & $d(\AA)$ & $\begin{array}{c}\text { I\% peak } \\
\text { area }\end{array}$ & $\begin{array}{c}\text { I\% peak } \\
\text { height }\end{array}$ & $d(\AA)$ & $\begin{array}{c}\text { I\% peak } \\
\text { area }\end{array}$ & $\begin{array}{c}1 \% \text { peak } \\
\text { height }\end{array}$ & $d(\AA)$ & $\begin{array}{c}\text { I\% peak } \\
\text { area }\end{array}$ & $\begin{array}{c}\text { I\% peak } \\
\text { height }\end{array}$ & ID & $d(\AA)$ & $\begin{array}{c}\text { I\% peak } \\
\text { height }\end{array}$ \\
\hline 3.636 & 100 & 100 & 3.639 & 100 & 100 & 3.636 & 100 & 100 & 3.639 & 100 & 100 & Sodalite & 3.624 & 100 \\
\hline \multirow[t]{8}{*}{3.442} & 0.2 & 0.6 & & & & & & & & & & & 3.58 & \\
\hline & & & & & & & & & & & & & 3.53 & \\
\hline & & & & & & & & & & & & & 3.40 & \\
\hline & & & & & & & & & & & & & 3.38 & \\
\hline & & & & & & & & & & & & & 3.34 & \\
\hline & & & & & & & & & 3.328 & 0.4 & 2.9 & & 3.31 & \\
\hline & & & 3.319 & 0.3 & 2.8 & & & & & & & & 3.30 & \\
\hline & & & & & & & & & & & & Nepheline & 3.2731 & 70 \\
\hline 3.279 & 0.4 & 0.6 & 3.278 & 0.9 & 3.0 & 3.281 & 0.8 & 3.5 & 3.274 & 1.2 & 3.6 & Halite & 3.26 & 13 \\
\hline \multirow[t]{6}{*}{3.196} & 0.4 & 0.4 & & & & 3.164 & 0.3 & 2.9 & & & & & 3.15 & \\
\hline & & & & & & 3.136 & 0.1 & 2.8 & & & & & 3.12 & \\
\hline & & & & & & & & & & & & & 3.10 & \\
\hline & & & & & & & & & 3.085 & 0.2 & 2.6 & & 3.07 & \\
\hline & & & 3.056 & 0.5 & 2.5 & 3.058 & 0.2 & 2.7 & 3.063 & 0.7 & 2.9 & Nepheline & 3.0461 & 18 \\
\hline & & & & & & & & & & & & & 3.03 & \\
\hline \multirow[t]{2}{*}{3.015} & 0.4 & 0.4 & & & & & & & & & & & 3.01 & \\
\hline & & & 3.021 & 0.9 & 2.6 & 3.013 & 0.2 & 2.8 & 3.016 & 0.7 & 2.9 & Nepheline & 3.0059 & 100 \\
\hline \multirow[t]{4}{*}{2.939} & 0.3 & 0.3 & & & & & & & & & & & 2.95 & \\
\hline & & & & & & & & & & & & & 2.90 & \\
\hline & & & 2.888 & 0.3 & 2.3 & & & & & & & Nepheline & 2.8864 & 35 \\
\hline & & & 2.868 & 0.2 & 2.1 & & & & & & & & 2.85 & \\
\hline 2.832 & 8.9 & 4.0 & 2.838 & 11.5 & 4.5 & 2.831 & 10.3 & 4.5 & 2.832 & 7.0 & 4.3 & Halite & 2.821 & 100 \\
\hline \multirow[t]{7}{*}{2.813} & 10.2 & 9.0 & 2.814 & 11.8 & 10.3 & 2.812 & 10.5 & 9.8 & 2.813 & 10.5 & 10.4 & Sodalite & 2.807 & 8 \\
\hline & & & & & & & & & & & & & 2.78 & \\
\hline & & & & & & & & & & & & & 2.73 & \\
\hline & & & & & & & & & 2.720 & 0.2 & 2.0 & & 2.70 & \\
\hline & & & & & & & & & & & & & 2.68 & \\
\hline & & & & & & & & & & & & & 2.65 & \\
\hline & & & & & & & & & & & & & 2.60 & \\
\hline \multirow[t]{5}{*}{2.567} & 19.8 & 19.5 & 2.569 & 20.0 & 19.2 & 2.567 & 19.9 & 18.4 & 2.567 & 20.6 & 20.8 & Sodalite & 2.563 & 16 \\
\hline & & & & & & & & & & & & & 2.54 & \\
\hline & & & 2.509 & 0.3 & 1.5 & 2.539 & 0.2 & 2.1 & & & & Nepheline & 2.5000 & 14 \\
\hline & & & & & & & & & & & & & 2.49 & \\
\hline & & & & & & & & & & & & & 2.45 & \\
\hline
\end{tabular}


Table 26. (continued)

\begin{tabular}{|c|c|c|c|c|c|c|c|c|c|c|c|c|c|c|}
\hline \multicolumn{3}{|c|}{$800^{\circ} \mathrm{C} 4$ hours } & \multicolumn{3}{|c|}{$800^{\circ} \mathrm{C} 28$ hours } & \multicolumn{3}{|c|}{$800^{\circ} \mathrm{C} 52$ hours } & \multicolumn{3}{|c|}{$800^{\circ} \mathrm{C} 100$ hours } & \multicolumn{3}{|c|}{ Reference phase } \\
\hline$d(\AA)$ & $\begin{array}{c}\text { I\% peak } \\
\text { area }\end{array}$ & $\begin{array}{c}\text { I\% peak } \\
\text { height }\end{array}$ & $d(\AA)$ & $\begin{array}{c}1 \% \text { peak } \\
\text { area }\end{array}$ & $\begin{array}{c}\text { I\% peak } \\
\text { height }\end{array}$ & $d(\AA)$ & $\begin{array}{c}\text { I\% peak } \\
\text { area }\end{array}$ & $\begin{array}{c}\text { I\% peak } \\
\text { height }\end{array}$ & $d(\AA)$ & $\begin{array}{c}\text { I\% peak } \\
\text { area }\end{array}$ & $\begin{array}{c}\text { I\% peak } \\
\text { height }\end{array}$ & ID & $d(\AA)$ & $\begin{array}{c}1 \% \text { peak } \\
\text { height }\end{array}$ \\
\hline & & & & & & & & & & & & Nepheline & 2.4007 & 10 \\
\hline \multirow[t]{6}{*}{2.376} & 20.5 & 19.7 & 2.377 & 20.7 & 18.6 & 2.376 & 20.8 & 17.9 & 2.376 & 20.3 & 19.8 & Sodalite & 2.373 & 16 \\
\hline & & & 2.343 & 0.3 & 1.5 & & & & & & & Nepheline & 2.3395 & 35 \\
\hline & & & & & & & & & & & & & 2.31 & \\
\hline & & & & & & & & & & & & Nepheline & 2.3074 & 25 \\
\hline & & & & & & & & & & & & & 2.29 & \\
\hline & & & 2.256 & 0.1 & 1.3 & & & & & & & & 2.26 & \\
\hline \multirow[t]{4}{*}{2.222} & 1.2 & 1.3 & 2.221 & 1.2 & 2.2 & 2.219 & 1.1 & 2.3 & 2.220 & 1.3 & 2.5 & Sodalite & 2.219 & 1 \\
\hline & & & & & & & & & & & & Nepheline & 2.163 & \\
\hline & & & & & & & & & & & & Nepheline & 2.1188 & \\
\hline & & & & & & & & & & & & Nepheline & 2.0938 & 5 \\
\hline 2.094 & 31.5 & 27.8 & 2.094 & 31.6 & 26.7 & 2.094 & 30.6 & 25 & 2.093 & 31.4 & 28.2 & Sodalite & 2.093 & 20 \\
\hline 2.000 & 3.4 & 2.0 & 2.002 & 1.9 & 2.1 & 2.000 & 1.2 & 2.3 & 2.002 & 1.6 & 2.2 & Halite & 1.994 & 55 \\
\hline \multirow[t]{4}{*}{1.986} & 5.0 & 4.4 & 1.987 & 5.4 & 5 & 1.985 & 5.4 & 4.7 & 1.986 & 5.4 & 5.4 & Sodalite & 1.985 & 3 \\
\hline & & & & & & & & & & & & & 1.97 & \\
\hline & & & & & & & & & & & & & 1.96 & \\
\hline & & & & & & & & & 1.938 & 0.2 & 1.5 & Nepheline & 1.9313 & 6 \\
\hline \multirow[t]{2}{*}{1.893} & 3.9 & 3.8 & 1.894 & 3.9 & 4.1 & 1.893 & 3.4 & 4.4 & 1.893 & 4.2 & 4.7 & Sodalite & 1.893 & 3 \\
\hline & & & & & & & & & & & & Nepheline & 1.8411 & 2 \\
\hline \multirow[t]{2}{*}{1.813} & 4.0 & 3.0 & 1.813 & 3.7 & 3.7 & 1.813 & 3.8 & 3.8 & 1.812 & 3.7 & 4.3 & Sodalite & 1.8122 & 2 \\
\hline & & & & & & & & & & & & Nepheline & 1.7923 & 5 \\
\hline \multirow[t]{6}{*}{1.742} & 3.7 & 3.5 & 1.742 & 3.7 & 3.9 & 1.742 & 3.9 & 3.8 & 1.742 & 4.4 & 4.5 & Sodalite & 1.7413 & 2 \\
\hline & & & & & & & & & & & & & 1.72 & \\
\hline & & & & & & & & & & & & Nepheline & 1.6942 & 5 \\
\hline & & & & & & & & & & & & & 1.67 & \\
\hline & & & & & & & & & & & & & 1.65 & \\
\hline & & & & & & 1.633 & 0.5 & 1.5 & & & & Nepheline & 1.6346 & 6 \\
\hline 1.634 & 1.0 & 0.5 & & & & & & & & & & Halite & 1.628 & 15 \\
\hline \multirow[t]{3}{*}{1.621} & 3.3 & 2.5 & 1.621 & 3.3 & 3.2 & 1.620 & 3.3 & 3.2 & 1.620 & 3.5 & 3.7 & \begin{tabular}{|l|} 
Sodalite \\
\end{tabular} & 1.621 & 2 \\
\hline & & & & & & & & & & & & Nepheline & 1.615 & 8 \\
\hline & & & & & & & & & & & & Nepheline & 1.6002 & 4 \\
\hline \multirow[t]{2}{*}{1.569} & 12.3 & 8.9 & 1.569 & 12.3 & 9.1 & 1.569 & 12.6 & 9.0 & 1.569 & 12.7 & 10.4 & Sodalite & 1.5696 & 5 \\
\hline & & & & & & & & & & & & Nepheline & 1.5614 & 14 \\
\hline \multirow[t]{2}{*}{1.523} & 6.2 & 4.2 & 1.522 & 5.8 & 5.3 & 1.522 & 5.9 & 5.2 & 1.522 & 6.5 & 5.8 & Sodalite & 1.5227 & 3 \\
\hline & & & & & & & & & & & & & 1.51 & \\
\hline 1.479 & 9.5 & 6.8 & 1.479 & 9.5 & 7.2 & 1.479 & 9.6 & 7.2 & 1.479 & 9.8 & 8.4 & Sodalite & 1.4797 & 4 \\
\hline
\end{tabular}


Table 26. (continued)

\begin{tabular}{|c|c|c|c|c|c|c|c|c|c|c|c|c|c|c|}
\hline \multicolumn{3}{|c|}{$800^{\circ} \mathrm{C} 4$ hours } & \multicolumn{3}{|c|}{$800^{\circ} \mathrm{C} 28$ hours } & \multicolumn{3}{|c|}{$800^{\circ} \mathrm{C} 52$ hours } & \multicolumn{3}{|c|}{$800^{\circ} \mathrm{C} 100$ hours } & \multicolumn{3}{|c|}{ Reference phase } \\
\hline$d(\AA)$ & $\begin{array}{c}\text { I\% peak } \\
\text { area }\end{array}$ & $\begin{array}{c}1 \% \text { peak } \\
\text { height }\end{array}$ & $d(\AA)$ & $\begin{array}{c}1 \% \text { peak } \\
\text { area }\end{array}$ & $\begin{array}{c}1 \% \text { peak } \\
\text { height }\end{array}$ & $d(\AA)$ & $\begin{array}{c}1 \% \text { peak } \\
\text { area }\end{array}$ & $\begin{array}{c}1 \% \text { peak } \\
\text { height }\end{array}$ & $d(\AA)$ & $\begin{array}{c}1 \% \text { peak } \\
\text { area }\end{array}$ & $\begin{array}{c}1 \% \text { peak } \\
\text { height }\end{array}$ & ID & $d(\AA)$ & $\begin{array}{c}1 \% \text { peak } \\
\text { height }\end{array}$ \\
\hline & & & & & & & & & & & & Nepheline & 1.4687 & 5 \\
\hline & & & & & & & & & & & & Nepheline & 1.4555 & 3 \\
\hline 1.439 & 10.7 & 7.3 & 1.440 & 10.3 & 7.6 & 1.439 & 10.9 & 7.5 & 1.439 & 10.2 & 8.2 & Sodalite & 1.4404 & 5 \\
\hline & & & & & & & & & & & & Nepheline & 1.4282 & 7 \\
\hline & & & & & & 1.413 & 0.4 & 1.3 & 1.413 & 0.3 & 1.3 & Halite & 1.41 & 6 \\
\hline 1.403 & 0.7 & 0.6 & 1.403 & 0.8 & 1.4 & 1.403 & 0.7 & 1.6 & 1.402 & 0.4 & 1.6 & Sodalite & 1.4038 & 1 \\
\hline & & & & & & & & & & & & & 1.40 & \\
\hline & & & & & & & & & & & & Nepheline & 1.3865 & 6 \\
\hline 1.369 & 4.3 & 2.6 & 1.369 & 4.1 & 3.2 & 1.368 & 4.1 & 3.4 & 1.369 & 4.0 & 4.0 & Sodalite & 1.3699 & 6 \\
\hline 1.338 & 4.6 & 3.3 & 1.337 & 4.6 & 3.7 & 1.338 & 4.3 & 3.6 & 1.337 & 4.4 & 3.9 & Sodalite & 1.3385 & 2 \\
\hline & & & & & & & & & & & & & 1.34 & \\
\hline 1.308 & 4.1 & 2.7 & 1.308 & 3.9 & 3.7 & 1.308 & 3.9 & 3.6 & 1.308 & 3.7 & 3.8 & Sodalite & 1.3091 & 2 \\
\hline & & & & & & & & & & & & & 1.31 & \\
\hline 1.281 & 3.4 & 1.9 & 1.280 & 3.5 & 2.8 & 1.281 & 3.0 & 2.8 & 1.280 & 2.6 & 3.2 & Sodalite & 1.2814 & 2 \\
\hline 1.277 & 2.2 & 1.1 & 1.278 & 2.8 & 1.7 & & & & & & & Nepheline & 1.279 & 6 \\
\hline 1.263 & 0.7 & 0.5 & & & & & & & & & & Sodalite & 1.2684 & 1 \\
\hline 1.255 & 0.4 & 0.3 & & & & & & & & & & Sodalite & 1.2555 & 1 \\
\hline & & & 1.231 & 1.2 & 1.2 & 1.230 & 0.5 & 1.3 & 1.230 & 0.4 & 1.2 & Nepheline & 1.2347 & 4 \\
\hline 1.230 & 0.6 & 0.6 & & & & & & & & & & & 1.23 & \\
\hline 1.207 & 9.5 & 5.4 & 1.207 & 7.3 & 5.9 & 1.207 & 8.6 & 6.0 & 1.207 & 9.1 & 6.5 & Sodalite & 1.2081 & 3 \\
\hline
\end{tabular}


Table 27. Results of XRD analyses of short-term heat-treated CWF materials heated at $850{ }^{\circ} \mathrm{C}$

\begin{tabular}{|c|c|c|c|c|c|c|c|c|c|c|c|c|c|c|}
\hline \multicolumn{3}{|c|}{$850^{\circ} \mathrm{C} 4$ hours } & \multicolumn{3}{|c|}{$850^{\circ} \mathrm{C} 28$ hours } & \multicolumn{3}{|c|}{$850^{\circ} \mathrm{C} 52$ hours } & \multicolumn{3}{|c|}{$850^{\circ} \mathrm{C} 100$ hours } & \multicolumn{3}{|c|}{ Reference phase } \\
\hline$d(\AA)$ & $\begin{array}{c}1 \% \text { peak } \\
\text { area }\end{array}$ & $\begin{array}{c}\text { I\% peak } \\
\text { height }\end{array}$ & $d(\AA)$ & $\begin{array}{c}1 \% \text { peak } \\
\text { area }\end{array}$ & $\begin{array}{c}\text { I\% peak } \\
\text { height }\end{array}$ & $d(\AA)$ & $\begin{array}{c}\text { I\% peak } \\
\text { area }\end{array}$ & $\begin{array}{c}1 \% \text { peak } \\
\text { height }\end{array}$ & $d(\AA)$ & $\begin{array}{c}1 \% \text { peak } \\
\text { area }\end{array}$ & $\begin{array}{c}1 \% \text { peak } \\
\text { height }\end{array}$ & ID & $d(\AA)$ & $\begin{array}{c}1 \% \text { peak } \\
\text { height }\end{array}$ \\
\hline & & & & & & & & & 7.946 & 0.2 & 1.9 & & 7.87 & \\
\hline & & & 7.417 & 0.1 & 1.5 & & & & & & & & 7.38 & \\
\hline & & & & & & & & & & & & & 6.95 & \\
\hline & & & & & & & & & & & & & 6.90 & \\
\hline & & & & & & & & & & & & & 6.78 & \\
\hline 6.216 & 30.3 & 20.4 & 6.321 & 24.7 & 25.8 & 6.321 & 29 & 28.5 & 6.348 & 25.4 & 23.8 & Sodalite & 6.28 & 40 \\
\hline & & & & & & & & & & & & & 5.76 & \\
\hline & & & & & & & & & & & & & 5.55 & \\
\hline & & & & & & 5.501 & 0.2 & 1.6 & & & & & 5.47 & \\
\hline & & & 5.444 & 0.1 & 1.6 & & & & & & & & 5.40 & \\
\hline & & & 5.298 & 0.3 & 1.8 & & & & & & & & 5.31 & \\
\hline & & & 5.100 & 0.2 & 1.7 & & & & & & & & 5.09 & \\
\hline & & & 5.018 & 0.1 & 1.7 & 5.027 & 0.2 & 2.0 & 5.040 & 0.1 & 2.0 & Nepheline & 5.0058 & 10 \\
\hline & & & & & & 4.874 & 0.2 & 2.0 & 4.909 & 0.2 & 1.9 & & 4.86 & \\
\hline & & & & & & & & & & & & & 4.72 & \\
\hline & & & & & & & & & & & & & 4.75 & \\
\hline & & & & & & & & & & & & & 4.66 & \\
\hline & & & & & & & & & & & & & 4.62 & \\
\hline & & & 4.555 & 0.2 & 2.3 & & & & & & & & 4.53 & \\
\hline 4.410 & 7.2 & 6.3 & 4.458 & 7.1 & 9.1 & 4.458 & 6.8 & 8.9 & 4.471 & 6.8 & 8.7 & Sodalite & 4.44 & 5 \\
\hline & & & & & & & & & & & & & 4.20 & \\
\hline 4.301 & 0.2 & 0.3 & 4.353 & 0.3 & 2.6 & & & & & & & Nepheline & 4.3335 & 35 \\
\hline & & & & & & & & & & & & & 4.25 & \\
\hline & & & & & & & & & & & & & 4.19 & \\
\hline & & & 4.198 & 0.6 & 3.0 & 4.201 & 0.8 & 3.1 & 4.207 & 0.5 & 3.3 & Nepheline & 4.1766 & 80 \\
\hline & & & & & & 4.134 & 0.2 & 2.8 & & & & & 4.12 & \\
\hline & & & & & & & & & & & & & 4.08 & \\
\hline 3.939 & 1.0 & 1.0 & 3.987 & 0.8 & 3.4 & 3.989 & 0.8 & 3.6 & 3.997 & 0.9 & 3.7 & Sodalite & 3.97 & 1 \\
\hline & & & & & & & & & & & & & 3.92 & \\
\hline & & & & & & & & & & & & & 3.9 & \\
\hline 3.815 & 0.3 & 0.3 & 3.867 & 0.4 & 3.2 & 3.860 & 1.0 & 3.8 & 3.867 & 1.0 & 3.7 & Nepheline & 3.8438 & 100 \\
\hline & & & & & & & & & & & & & 3.80 & \\
\hline & & & & & & & & & & & & Nepheline & 3.7614 & 2 \\
\hline & & & & & & & & & & & & & 3.70 & \\
\hline 3.601 & 100 & 100 & 3.636 & 100 & 100 & 3.636 & 100 & 100 & 3.645 & 100 & 100 & Sodalite & 3.624 & 100 \\
\hline
\end{tabular}


Table 27. (continued)

\begin{tabular}{|c|c|c|c|c|c|c|c|c|c|c|c|c|c|c|}
\hline \multicolumn{3}{|c|}{$850^{\circ} \mathrm{C} 4$ hours } & \multicolumn{3}{|c|}{$850^{\circ} \mathrm{C} 28$ hours } & \multicolumn{3}{|c|}{$850^{\circ} \mathrm{C} 52$ hours } & \multicolumn{3}{|c|}{$850^{\circ} \mathrm{C} 100$ hours } & \multicolumn{3}{|c|}{ Reference phase } \\
\hline$d(\AA)$ & $\begin{array}{c}\% \text { peak } \\
\text { area }\end{array}$ & $\begin{array}{c}\% \text { peak } \\
\text { height }\end{array}$ & $d(\AA)$ & $\begin{array}{c}1 \% \text { peak } \\
\text { area }\end{array}$ & $\begin{array}{c}1 \% \text { peak } \\
\text { height }\end{array}$ & $d(\AA)$ & $\begin{array}{c}1 \% \text { peak } \\
\text { area }\end{array}$ & $\begin{array}{c}1 \% \text { peak } \\
\text { height }\end{array}$ & $d(\AA)$ & $\begin{array}{c}\text { I\% peak } \\
\text { area }\end{array}$ & $\begin{array}{c}1 \% \text { peak } \\
\text { height }\end{array}$ & ID & $d(\AA)$ & $\begin{array}{c}1 \% \text { peak } \\
\text { height }\end{array}$ \\
\hline & & & & & & & & & & & & & 3.58 & \\
\hline & & & & & & & & & & & & & 3.53 & \\
\hline & & & & & & & & & & & & & 3.40 & \\
\hline & & & & & & & & & & & & & 3.38 & \\
\hline & & & 3.350 & 0.2 & 2.8 & & & & & & & & 3.34 & \\
\hline & & & & & & & & & & & & & 3.31 & \\
\hline & & & & & & & & & & & & & 3.30 & \\
\hline & & & & & & & & & & & & Nepheline & 3.2731 & 70 \\
\hline 3.245 & 0.3 & 0.7 & 3.279 & 1.2 & 3.3 & 3.283 & 1.4 & 3.4 & 3.291 & 1.1 & 3.8 & Halite & 3.26 & 13 \\
\hline & & & & & & & & & 3.233 & 0.3 & 3.0 & & 3.15 & \\
\hline & & & 3.144 & 0.2 & 2.8 & & & & & & & & 3.12 & \\
\hline & & & & & & 3.118 & 0.2 & 2.5 & 3.123 & 0.2 & 2.6 & & 3.10 & \\
\hline & & & & & & 3.097 & 0.2 & 2.4 & & & & & 3.07 & \\
\hline & & & & & & 3.063 & 0.6 & 2.7 & 3.063 & 0.3 & 2.8 & Nepheline & 3.0461 & 18 \\
\hline & & & & & & & & & & & & & 3.03 & \\
\hline & & & & & & & & & & & & & 3.01 & \\
\hline & & & & & & 3.013 & 1.0 & 2.8 & 3.016 & 0.9 & 3.2 & Nepheline & 3.0059 & 100 \\
\hline & & & & & & 2.995 & 0.2 & 2.4 & & & & & 2.95 & \\
\hline & & & & & & 2.914 & 0.2 & 2.3 & & & & & 2.90 & \\
\hline & & & 2.893 & 0.2 & 2.3 & 2.898 & 0.4 & 2.3 & 2.896 & 0.4 & 2.5 & Nepheline & 2.8864 & 35 \\
\hline & & & & & & & & & & & & & 2.85 & \\
\hline 2.812 & 11.1 & 3.9 & 2.833 & 7.4 & 5.4 & 2.832 & 9.3 & 5.0 & 2.838 & 10.4 & 4.2 & Halite & 2.821 & 100 \\
\hline 2.793 & 11.4 & 9.4 & 2.813 & 10.4 & 10.0 & 2.813 & 10.1 & 9.6 & 2.817 & 10.8 & 10.5 & Sodalite & 2.807 & 8 \\
\hline & & & & & & & & & & & & & 2.78 & \\
\hline & & & 2.760 & 0.1 & 1.9 & 2.769 & 0.2 & 1.9 & & & & & 2.73 & \\
\hline & & & & & & & & & & & & & 2.70 & \\
\hline & & & & & & & & & & & & & 2.68 & \\
\hline & & & & & & & & & & & & & 2.65 & \\
\hline & & & & & & & & & & & & & 2.60 & \\
\hline 2.550 & 19.1 & 19.2 & 2.567 & 19.3 & 18.6 & 2.567 & 19.5 & 18.6 & 2.570 & 20.1 & 20.3 & Sodalite & 2.563 & 16 \\
\hline & & & & & & & & & & & & & 2.54 & \\
\hline & & & & & & & & & & & & Nepheline & 2.5000 & 14 \\
\hline & & & & & & & & & & & & & 2.49 & \\
\hline & & & & & & & & & 2.494 & 0.2 & 1.7 & & 2.45 & \\
\hline
\end{tabular}


Table 27. (continued)

\begin{tabular}{|c|c|c|c|c|c|c|c|c|c|c|c|c|c|c|}
\hline \multicolumn{3}{|c|}{$850^{\circ} \mathrm{C} 4$ hours } & \multicolumn{3}{|c|}{$850^{\circ} \mathrm{C} 28$ hours } & \multicolumn{3}{|c|}{$850^{\circ} \mathrm{C} 52$ hours } & \multicolumn{3}{|c|}{$850^{\circ} \mathrm{C} 100$ hours } & \multicolumn{3}{|c|}{ Reference phase } \\
\hline$d(\AA)$ & $\begin{array}{c}1 \% \text { peak } \\
\text { area }\end{array}$ & $\begin{array}{c}1 \% \text { peak } \\
\text { height }\end{array}$ & $d(\AA)$ & $\begin{array}{c}\text { I\% peak } \\
\text { area }\end{array}$ & $\begin{array}{c}1 \% \text { peak } \\
\text { height }\end{array}$ & $d(\AA)$ & $\begin{array}{c}1 \% \text { peak } \\
\text { area }\end{array}$ & $\begin{array}{c}1 \% \text { peak } \\
\text { height }\end{array}$ & $d(\AA)$ & $\begin{array}{c}1 \% \text { peak } \\
\text { area }\end{array}$ & $\begin{array}{c}\text { I\% peak } \\
\text { height }\end{array}$ & ID & $d(\AA)$ & $\begin{array}{c}1 \% \text { peak } \\
\text { height }\end{array}$ \\
\hline & & & & & & & & & & & & Nepheline & 2.4007 & 10 \\
\hline \multirow[t]{6}{*}{2.361} & 19.7 & 20.0 & 2.376 & 19.8 & 18.5 & 2.376 & 20.3 & 18.6 & 2.379 & 21.3 & 20.3 & Sodalite & 2.373 & 16 \\
\hline & & & 2.353 & 0.4 & 1.6 & 2.347 & 0.4 & 1.6 & 2.350 & 0.6 & 1.8 & Nepheline & 2.3395 & 35 \\
\hline & & & & & & & & & & & & & 2.31 & \\
\hline & & & & & & 2.310 & 0.2 & 1.4 & 2.315 & 0.2 & 1.6 & Nepheline & 2.3074 & 25 \\
\hline & & & & & & & & & & & & & 2.29 & \\
\hline & & & & & & & & & & & & & 2.26 & \\
\hline \multirow[t]{4}{*}{2.210} & 1.0 & 1.3 & 2.222 & 1.7 & 2.3 & 2.221 & 1.0 & 2.2 & 2.224 & 1.1 & 2.3 & Sodalite & 2.219 & 1 \\
\hline & & & & & & & & & & & & Nepheline & 2.163 & \\
\hline & & & & & & & & & & & & Nepheline & 2.1188 & \\
\hline & & & & & & & & & & & & Nepheline & 2.0938 & 5 \\
\hline 2.083 & 29.5 & 29.1 & 2.094 & 31.0 & 26.0 & 2.094 & 30.1 & 25.6 & 2.097 & 32.4 & 27.8 & Sodalite & 2.093 & 20 \\
\hline 1.991 & 2.8 & 1.7 & 2.000 & 3.0 & 2.5 & 2.000 & 2.5 & 2.4 & 2.003 & 2.6 & 2.2 & Halite & 1.994 & 55 \\
\hline \multirow[t]{4}{*}{1.976} & 4.9 & 4.8 & 1.987 & 5.3 & 4.8 & 1.986 & 4.9 & 5.0 & 1.989 & 5.6 & 5.3 & Sodalite & 1.985 & 3 \\
\hline & & & & & & & & & & & & & 1.97 & \\
\hline & & & & & & & & & & & & & 1.96 & \\
\hline & & & & & & & & & 1.937 & 0.1 & 1.4 & Nepheline & 1.9313 & 6 \\
\hline \multirow[t]{2}{*}{1.885} & 4.1 & 3.7 & 1.894 & 3.8 & 4.1 & 1.894 & 3.8 & 3.9 & 1.895 & 4.0 & 4.5 & Sodalite & 1.893 & 3 \\
\hline & & & & & & & & & 1.861 & 0.1 & 1.2 & Nepheline & 1.8411 & 2 \\
\hline \multirow[t]{2}{*}{1.805} & 3.0 & 3.1 & 1.813 & 3.9 & 3.4 & 1.813 & 3.2 & 3.6 & 1.815 & 3.6 & 3.8 & Sodalite & 1.8122 & 2 \\
\hline & & & & & & & & & & & & Nepheline & 1.7923 & 5 \\
\hline \multirow[t]{5}{*}{1.734} & 3.6 & 3.3 & 1.742 & 3.9 & 3.8 & 1.742 & 3.5 & 3.4 & 1.743 & 4.1 & 4.3 & Sodalite & 1.7413 & 2 \\
\hline & & & & & & & & & & & & & 1.72 & \\
\hline & & & & & & & & & & & & Nepheline & 1.6942 & 5 \\
\hline & & & & & & & & & & & & & 1.67 & \\
\hline & & & & & & & & & & & & & 1.65 & \\
\hline \multirow[t]{2}{*}{1.627} & 0.6 & 0.6 & & & & 1.633 & 0.9 & 1.5 & & & & Nepheline & 1.6346 & 6 \\
\hline & & & & & & & & & & & & Halite & 1.628 & 15 \\
\hline \multirow[t]{3}{*}{1.614} & 3.1 & 2.5 & 1.621 & 3.3 & 3.0 & 1.620 & 3.0 & 3.1 & 1.622 & 3.6 & 3.2 & Sodalite & 1.621 & 2 \\
\hline & & & & & & & & & & & & Nepheline & 1.615 & 8 \\
\hline & & & & & & & & & & & & Nepheline & 1.6002 & 4 \\
\hline \multirow[t]{2}{*}{1.564} & 13 & 9.6 & 1.570 & 11.8 & 8.8 & 1.569 & 12.3 & 9.2 & 1.571 & 12.7 & 9.5 & Sodalite & 1.5696 & 5 \\
\hline & & & & & & & & & & & & Nepheline & 1.5614 & 14 \\
\hline \multirow[t]{2}{*}{1.517} & 5.6 & 4.8 & 1.522 & 6.0 & 4.9 & 1.522 & 5.9 & 4.9 & 1.524 & 5.7 & 5.3 & Sodalite & 1.5227 & 3 \\
\hline & & & & & & & & & & & & & 1.51 & \\
\hline 1.475 & 9 & 7.5 & 1.479 & 9.5 & 6.9 & 1.479 & 9.5 & 7.1 & 1.480 & 9.1 & 7.7 & Sodalite & 1.4797 & 4 \\
\hline
\end{tabular}


Table 27. (continued)

\begin{tabular}{|c|c|c|c|c|c|c|c|c|c|c|c|c|c|c|}
\hline \multicolumn{3}{|c|}{$850^{\circ} \mathrm{C} 4$ hours } & \multicolumn{3}{|c|}{$850^{\circ} \mathrm{C} 28$ hours } & \multicolumn{3}{|c|}{$850^{\circ} \mathrm{C} 52$ hours } & \multicolumn{3}{|c|}{$850^{\circ} \mathrm{C} 100$ hours } & \multicolumn{3}{|c|}{ Reference phase } \\
\hline$d(\AA)$ & $\begin{array}{c}1 \% \text { peak } \\
\text { area }\end{array}$ & $\begin{array}{c}1 \% \text { peak } \\
\text { height }\end{array}$ & $d(\AA)$ & $\begin{array}{c}1 \% \text { peak } \\
\text { area }\end{array}$ & $\begin{array}{c}1 \% \text { peak } \\
\text { height }\end{array}$ & $d(\AA)$ & $\begin{array}{c}\text { I\% peak } \\
\text { area }\end{array}$ & $\begin{array}{c}1 \% \text { peak } \\
\text { height }\end{array}$ & $d(\AA)$ & $\begin{array}{c}1 \% \text { peak } \\
\text { area }\end{array}$ & $\begin{array}{c}1 \% \text { peak } \\
\text { height }\end{array}$ & ID & $d(\AA)$ & $\begin{array}{c}\text { I\% peak } \\
\text { height }\end{array}$ \\
\hline & & & & & & & & & & & & Nepheline & 1.4687 & 5 \\
\hline & & & & & & & & & & & & Nepheline & 1.4555 & 3 \\
\hline 1.435 & 11.6 & 7.6 & 1.440 & 10.3 & 7.4 & 1.440 & 10.0 & 7.3 & 1.440 & 12.6 & 8.0 & Sodalite & 1.4404 & 5 \\
\hline & & & & & & & & & & & & Nepheline & 1.4282 & 7 \\
\hline & & & & & & & & & & & & Halite & 1.41 & 6 \\
\hline & & & 1.403 & 0.7 & 1.4 & 1.403 & 0.8 & 1.3 & 1.404 & 0.7 & 1.4 & Sodalite & 1.4038 & 1 \\
\hline 1.399 & 0.6 & 0.7 & & & & 1.399 & 0.3 & 1.2 & & & & & 1.40 & \\
\hline 1.366 & 3.3 & 2.8 & & & & & & & & & & Nepheline & 1.3865 & 6 \\
\hline & & & 1.369 & 3.9 & 3.4 & 1.369 & 4.0 & 3.4 & 1.370 & 3.8 & 3.9 & Sodalite & 1.3699 & 6 \\
\hline 1.334 & 3.7 & 3.0 & & & & & & & & & & Sodalite & 1.3385 & 2 \\
\hline & & & 1.338 & 4.1 & 3.4 & 1.337 & 3.9 & 3.5 & 1.339 & 3.7 & 3.5 & & 1.34 & \\
\hline 1.305 & 4.0 & 2.9 & 1.309 & 4.0 & 3.2 & 1.309 & 3.9 & 3.2 & 1.309 & 3.9 & 3.5 & Sodalite & 1.3091 & 2 \\
\hline & & & & & & & & & & & & & 1.31 & \\
\hline & & & 1.281 & 2.3 & 2.5 & 1.280 & 2.7 & 2.5 & 1.282 & 3.0 & 2.7 & Sodalite & 1.2814 & 2 \\
\hline & & & & & & & & & & & & Nepheline & 1.279 & 6 \\
\hline 1.278 & 3.0 & 2.2 & & & & & & & 1.264 & 0.3 & 1.1 & Sodalite & 1.2684 & 1 \\
\hline & & & & & & 1.254 & 0.1 & 1.0 & & & & Sodalite & 1.2555 & 1 \\
\hline 1.227 & 0.8 & 0.6 & 1.230 & 0.6 & 1.1 & 1.230 & 0.2 & 1.1 & 1.231 & 0.5 & 1.4 & Nepheline & 1.2347 & 4 \\
\hline & & & & & & & & & & & & & 1.23 & \\
\hline 1.205 & 6.4 & 5.8 & 1.207 & 6.7 & 5.4 & 1.207 & 7.4 & 5.7 & 1.208 & 9.1 & 6.6 & Sodalite & 1.2081 & 3 \\
\hline
\end{tabular}


Table 28. Peak heights used to identify sodalite, nepheline, and halite in XRD spectra of short-term heat-treated CWF samples

\begin{tabular}{|c|c|c|c|c|c|c|c|c|c|c|c|c|c|c|c|c|}
\hline $\begin{array}{c}\text { Reference } \\
\text { phase }\end{array}$ & \multicolumn{16}{|c|}{ Heat-treated CWF } \\
\hline $\begin{array}{c}d \text {-spacing, } \\
\AA\end{array}$ & $\begin{array}{c}600^{\circ} \mathrm{C} \\
4 \mathrm{~h}\end{array}$ & $\begin{array}{c}600^{\circ} \mathrm{C} \\
28 \mathrm{~h}\end{array}$ & $\begin{array}{c}600^{\circ} \mathrm{C} \\
52 \mathrm{~h}\end{array}$ & $\begin{array}{c}600^{\circ} \mathrm{C} \\
100 \mathrm{~h}\end{array}$ & $\begin{array}{c}700^{\circ} \mathrm{C} \\
4 \mathrm{~h}\end{array}$ & $\begin{array}{c}700^{\circ} \mathrm{C} \\
28 \mathrm{~h}\end{array}$ & $\begin{array}{c}700^{\circ} \mathrm{C} \\
52 \mathrm{~h} \\
\end{array}$ & $\begin{array}{c}700^{\circ} \mathrm{C} \\
100 \mathrm{~h}\end{array}$ & $\begin{array}{c}800^{\circ} \mathrm{C} \\
4 \mathrm{~h}\end{array}$ & $\begin{array}{c}800^{\circ} \mathrm{C} \\
28 \mathrm{~h}\end{array}$ & $\begin{array}{c}800^{\circ} \mathrm{C} \\
52 \mathrm{~h}\end{array}$ & $\begin{array}{c}800^{\circ} \mathrm{C} \\
100 \mathrm{~h}\end{array}$ & $\begin{array}{c}850^{\circ} \mathrm{C} \\
4 \mathrm{~h}\end{array}$ & $\begin{array}{c}850^{\circ} \mathrm{C} \\
28 \mathrm{~h}\end{array}$ & \begin{tabular}{|c|}
$850^{\circ} \mathrm{C}$ \\
$52 \mathrm{~h}$ \\
\end{tabular} & $\begin{array}{c}850^{\circ} \mathrm{C} \\
100 \mathrm{~h}\end{array}$ \\
\hline \multicolumn{17}{|c|}{ Halite } \\
\hline 3.26 & 0.8 & 3.2 & 3.6 & 3.8 & 0.5 & 3.2 & $\mathrm{nd}^{\mathrm{a}}$ & 2.7 & 0.6 & 3.0 & 3.5 & 3.6 & 0.7 & 3.3 & 3.4 & 3.8 \\
\hline 2.821 & 4.8 & 6.1 & 5.9 & 8.1 & 4.3 & 5.8 & 4.1 & 4.6 & 4.0 & 4.5 & 4.5 & 4.3 & 3.9 & 5.4 & 5.0 & 4.2 \\
\hline 1.994 & 2.1 & 3.0 & 3.5 & 3.8 & 2.2 & 3.1 & 1.8 & 2.2 & 2.0 & 2.1 & 2.3 & 2.2 & 1.7 & 2.5 & 2.4 & 2.2 \\
\hline 1.628 & 0.8 & 1.5 & 1.8 & 1.8 & nd & 1.7 & 0.8 & 1.2 & 0.5 & nd & nd & nd & nd & nd & nd & nd \\
\hline 1.41 & nd & nd & nd & 1.7 & 0.3 & nd & nd & nd & nd & nd & 1.3 & 1.3 & nd & nd & nd & nd \\
\hline \multicolumn{17}{|c|}{ Sodalite } \\
\hline 6.28 & 25.5 & 26.3 & 28.3 & 26.5 & 25.9 & 25.2 & 22.8 & 26.7 & 26.6 & 26.9 & 30.4 & 29.1 & 20.4 & 25.8 & 28.5 & 23.8 \\
\hline 3.624 & 100 & 100 & 100 & 100 & 100 & 100 & 100 & 100 & 100 & 100 & 100 & 100 & 100 & 100 & 100 & 100 \\
\hline 2.563 & 19.0 & 19.6 & 18.9 & 21.4 & 17.7 & 20.0 & 20.0 & 18.4 & 19.5 & 19.2 & 18.4 & 20.8 & 19.2 & 18.6 & 18.6 & 20.3 \\
\hline 2.373 & 19.3 & 20.2 & 18.5 & 20.0 & 18.0 & 20.4 & 20.1 & 18.5 & 19.7 & 18.6 & 17.9 & 19.8 & 20.0 & 18.5 & 18.6 & 20.3 \\
\hline 2.093 & 26.8 & 27.7 & 24.2 & 28.6 & 26.1 & 28.7 & 30.0 & 26.1 & 27.8 & 26.7 & 25.0 & 28.2 & 29.1 & 26.0 & 25.6 & 27.8 \\
\hline \multicolumn{17}{|c|}{ Nepheline } \\
\hline 4.3335 & nd & nd & nd & nd & nd & nd & nd & nd & nd & nd & 2.7 & 2.8 & 0.3 & 2.6 & nd & nd \\
\hline 4.1766 & nd & nd & nd & nd & nd & nd & nd & $\mathrm{nd}$ & nd & nd & nd & nd & nd & 3.0 & 3.1 & 3.3 \\
\hline 3.8438 & nd & nd & nd & nd & nd & nd & nd & 2.9 & nd & 3.1 & 3.4 & 3.5 & 0.3 & 3.2 & 3.8 & 3.7 \\
\hline 3.2731 & nd & nd & nd & nd & nd & nd & nd & nd & nd & nd & nd & nd & nd & nd & nd & nd \\
\hline 3.0059 & nd & nd & nd & 3.2 & nd & nd & nd & nd & nd & nd & 2.8 & 2.9 & nd & nd & 2.8 & 3.2 \\
\hline 2.8864 & nd & nd & nd & nd & nd & nd & nd & nd & nd & nd & nd & nd & nd & 2.3 & 2.3 & 2.5 \\
\hline 2.3395 & nd & nd & nd & nd & nd & nd & nd & nd & nd & 1.5 & nd & nd & nd & 1.6 & 1.6 & 1.8 \\
\hline
\end{tabular}

a "nd" indicates that a quantifiable peak was not detected at this $d$-spacing. 
Table 29. Compilation of area $\%$ values used to compare amounts of sodalite, nepheline, and halite in no-heat and heat-treated CWF samples ${ }^{\mathrm{a}, \mathrm{b}}$

\begin{tabular}{|c|c|c|c|c|c|c|c|c|c|c|c|c|c|c|c|c|}
\hline $\begin{array}{c}\text { Reference } \\
\text { phase }\end{array}$ & \multicolumn{16}{|c|}{ Heat-treated CWF } \\
\hline $\begin{array}{c}d \text {-spacing, } \\
\AA\end{array}$ & $\begin{array}{c}600^{\circ} \mathrm{C} \\
4 \mathrm{~h}\end{array}$ & $\begin{array}{c}600^{\circ} \mathrm{C} \\
28 \mathrm{~h} \\
\end{array}$ & $\begin{array}{c}600^{\circ} \mathrm{C} \\
52 \mathrm{~h} \\
\end{array}$ & $\begin{array}{c}600^{\circ} \mathrm{C} \\
100 \mathrm{~h}\end{array}$ & $\begin{array}{c}700^{\circ} \mathrm{C} \\
4 \mathrm{~h}\end{array}$ & $\begin{array}{c}700^{\circ} \mathrm{C} \\
28 \mathrm{~h} \\
\end{array}$ & $\begin{array}{c}700{ }^{\circ} \mathrm{C} \\
52 \mathrm{~h} \\
\end{array}$ & $\begin{array}{c}700^{\circ} \mathrm{C} \\
100 \mathrm{~h} \\
\end{array}$ & $\begin{array}{c}800^{\circ} \mathrm{C} \\
4 \mathrm{~h}\end{array}$ & $\begin{array}{c}800^{\circ} \mathrm{C} \\
28 \mathrm{~h}\end{array}$ & $\begin{array}{c}800^{\circ} \mathrm{C} \\
52 \mathrm{~h}\end{array}$ & \begin{tabular}{|c|}
$800^{\circ} \mathrm{C}$ \\
$100 \mathrm{~h}$ \\
\end{tabular} & $\begin{array}{c}850^{\circ} \mathrm{C} \\
4 \mathrm{~h}\end{array}$ & $\begin{array}{c}850^{\circ} \mathrm{C} \\
28 \mathrm{~h} \\
\end{array}$ & $\begin{array}{c}850^{\circ} \mathrm{C} \\
52 \mathrm{~h} \\
\end{array}$ & $\begin{array}{c}850^{\circ} \mathrm{C} \\
100 \mathrm{~h} \\
\end{array}$ \\
\hline \multicolumn{17}{|c|}{ Halite } \\
\hline 3.26 & 0.7 & 1.3 & 1.5 & 0.3 & 0.6 & 0.5 & nd & 0.8 & 0.4 & 0.9 & 0.8 & 1.2 & 0.3 & 1.2 & 1.4 & 1.1 \\
\hline 2.821 & 6.3 & 11.8 & 11.7 & 8.7 & 11.4 & 4.9 & 8.0 & 6.6 & 8.9 & 11.5 & 10.3 & 7.0 & 11.1 & 4.4 & 9.3 & 10.4 \\
\hline 1.994 & 5.1 & 3.1 & 4.5 & 4.6 & 3.8 & 3.4 & 2.2 & 2.1 & 3.4 & 1.9 & 1.2 & 1.6 & 2.8 & 3.0 & 2.5 & 2.6 \\
\hline 1.628 & 1.2 & 1.5 & 2.4 & 2.4 & nd & 0.9 & 1.0 & 0.7 & 1.0 & nd & nd & nd & nd & nd & nd & nd \\
\hline 1.41 & nd & nd & nd & nd & 0.2 & nd & nd & nd & nd & nd & 0.4 & 0.3 & nd & nd & nd & nd \\
\hline \multicolumn{17}{|c|}{ Sodalite } \\
\hline 6.28 & 25.7 & 26.1 & 26.7 & 25.3 & 26.5 & 27.2 & 24.1 & 26.0 & 26.2 & 27.7 & 26.3 & 26.5 & 30.3 & 24.7 & 29.0 & 25.4 \\
\hline 3.624 & 100 & 100 & 100 & 100 & 100 & 100 & 100 & 100 & 100 & 100 & 100 & 100 & 100 & 100 & 100 & 100 \\
\hline 2.563 & 20.0 & 19.7 & 19.6 & 20.1 & 19.6 & 20.8 & 19.9 & 20.1 & 19.8 & 20.0 & 19.9 & 20.6 & 19.1 & 19.3 & 19.5 & 20.1 \\
\hline 2.373 & 21.4 & 20.7 & 19.3 & 20.4 & 20.1 & 21.1 & 21.0 & 20.3 & 20.5 & 20.7 & 20.8 & 20.3 & 19.7 & 19.8 & 20.3 & 21.3 \\
\hline 2.093 & 32.0 & 31.0 & 29.6 & 30.6 & 30.4 & 32.1 & 30.3 & 31.2 & 31.5 & 31.6 & 30.6 & 31.4 & 29.5 & 31.0 & 30.1 & 32.4 \\
\hline \multicolumn{17}{|c|}{ Nepheline } \\
\hline 4.3335 & nd & nd & nd & nd & nd & nd & nd & nd & nd & nd & 0.3 & 0.3 & 0.2 & 0.3 & nd & nd \\
\hline 4.1766 & nd & nd & nd & nd & nd & nd & nd & nd & nd & nd & nd & nd & nd & 0.6 & 0.8 & 0.5 \\
\hline 3.8438 & nd & nd & nd & nd & nd & nd & nd & 0.6 & nd & 0.3 & 0.7 & 0.7 & 0.3 & 0.4 & 1.0 & 1.0 \\
\hline 3.2731 & nd & nd & nd & nd & nd & nd & nd & nd & nd & nd & nd & nd & nd & nd & nd & nd \\
\hline 3.0059 & nd & nd & nd & 0.5 & nd & nd & nd & nd & nd & nd & 0.2 & 0.7 & nd & nd & 1.0 & 0.9 \\
\hline 2.8864 & nd & nd & nd & nd & nd & nd & nd & nd & nd & 0.3 & nd & nd & nd & 0.2 & 0.4 & 0.4 \\
\hline 2.3395 & nd & nd & nd & nd & nd & nd & nd & nd & nd & 0.3 & nd & nd & nd & 0.4 & 0.4 & 0.6 \\
\hline
\end{tabular}

a "nd" indicates that a quantifiable peak was not detected at this $d$-spacing.

${ }^{\mathrm{b}}$ Values shown in bold font exceed the mean +2 standard deviations of I\% peak area for CWF material PC10402. 
Table 30. Test data for rapid water soluble tests with heat-treated CWF samples

\begin{tabular}{|c|c|c|c|c|c|c|c|c|c|c|}
\hline Material ID & $\begin{array}{c}\text { Beaker tare, } \\
\mathrm{g}\end{array}$ & $\begin{array}{c}\text { Beaker + } \\
\text { CWF, g }\end{array}$ & CWF, g & $\begin{array}{c}\text { Actual } \\
\text { mass } \\
\text { water, g }\end{array}$ & $\begin{array}{c}\text { Mass } \\
\text { water/CWF, } \\
\mathrm{mL} / \mathrm{g}\end{array}$ & Bottle tare, $\mathrm{g}$ & $\begin{array}{l}\text { Bottle + } \\
\text { RWS, g }\end{array}$ & $\begin{array}{c}\text { RWS } \\
\text { solution, g }\end{array}$ & $\begin{array}{c}\text { Bottle + } \\
\text { solution + } \\
\text { DIW, g } \\
\end{array}$ & $\begin{array}{c}\text { Dilution } \\
\text { factor }\end{array}$ \\
\hline \multicolumn{11}{|c|}{ Long-term heat-treated CWF } \\
\hline $400-1 w$ & 28.7104 & 29.0524 & 0.3420 & 3.43 & 10.03 & 11.14 & 14.17 & 3.03 & 21.14 & 3.3003 \\
\hline $400-4 w$ & 29.1916 & 29.9940 & 0.8024 & 8.35 & 10.41 & 11.16 & 18.76 & 7.60 & 21.08 & 1.3053 \\
\hline $400-3 m$ & 29.7664 & 30.0881 & 0.3217 & 3.23 & 10.04 & 11.15 & 13.99 & 2.84 & 21.12 & 3.5106 \\
\hline $400-6 m$ & 29.5204 & 31.0317 & 1.5113 & 15.20 & 10.06 & 11.14 & 25.21 & 14.07 & 25.21 & 1.0000 \\
\hline $400-1 y$ & 28.8831 & 30.1871 & 1.3040 & 13.09 & 10.04 & 11.13 & 23.07 & 11.94 & 23.07 & 1.0000 \\
\hline $500-1 w$ & 29.1887 & 29.4211 & 0.2324 & 2.30 & 9.90 & 11.13 & 13.04 & 1.91 & 20.86 & 5.0942 \\
\hline $500-4 w$ & 30.1792 & 31.0339 & 0.8547 & 8.56 & 10.02 & 11.20 & 19.00 & 7.80 & 21.19 & 1.2808 \\
\hline $500-3 m$ & 29.4514 & 30.0573 & 0.6059 & 6.86 & 11.32 & 11.13 & 17.38 & 6.25 & 21.16 & 1.6048 \\
\hline $500-6 m$ & 30.2380 & 31.5914 & 1.3534 & 13.58 & 10.03 & 11.19 & 23.55 & 12.36 & 23.55 & 1.0000 \\
\hline $500-1 y$ & 29.7511 & 31.0992 & 1.3481 & 13.53 & 10.04 & 11.18 & 23.52 & 12.34 & 23.52 & 1.0000 \\
\hline \multicolumn{11}{|c|}{ Short-term heat-treated CWF } \\
\hline No heat- $1^{a}$ & \multirow{3}{*}{29.76} & \multirow{3}{*}{33.83} & \multirow{3}{*}{4.07} & \multirow{3}{*}{40.77} & \multirow{3}{*}{10.02} & 10.98 & 21.78 & 10.80 & Not diluted & 1.0000 \\
\hline No heat-2 & & & & & & 11.10 & 22.22 & 11.12 & Not diluted & 1.0000 \\
\hline No heat-3 & & & & & & 11.08 & 22.86 & 11.78 & Not diluted & 1.0000 \\
\hline $600-28$ & 30.17 & 31.39 & 1.22 & 9.95 & 8.16 & 10.99 & 19.93 & 8.94 & Not diluted & 1.0000 \\
\hline $600-52$ & 29.18 & 30.51 & 1.33 & 13.33 & 10.02 & 10.94 & 22.71 & 11.77 & Not diluted & 1.0000 \\
\hline $600-100$ & 28.70 & 29.67 & 0.97 & 12.31 & 12.69 & 10.97 & 22.34 & 11.37 & Not diluted & 1.0000 \\
\hline $700-28$ & 29.80 & 31.04 & 1.24 & 12.39 & 9.99 & 10.99 & 21.97 & 10.98 & Not diluted & 1.0000 \\
\hline $700-52$ & 29.63 & 31.00 & 1.37 & 13.73 & 10.02 & 10.94 & 22.80 & 11.86 & Not diluted & 1.0000 \\
\hline $700-100$ & 30.24 & 31.30 & 1.06 & 10.61 & 10.01 & 10.97 & 21.71 & 10.74 & Not diluted & 1.0000 \\
\hline $800-28$ & 29.75 & 31.08 & 1.33 & 13.32 & 10.02 & 10.98 & 23.09 & 12.11 & Not diluted & 1.0000 \\
\hline $800-52$ & 29.45 & 30.92 & 1.47 & 14.81 & 10.07 & 11.01 & 22.79 & 11.78 & Not diluted & 1.0000 \\
\hline $800-100$ & 28.85 & 30.18 & 1.33 & 13.34 & 10.03 & 10.94 & 22.74 & 11.80 & Not diluted & 1.0000 \\
\hline $850-28$ & 28.88 & 30.19 & 1.31 & 13.09 & 9.99 & 10.93 & 22.83 & 11.90 & Not diluted & 1.0000 \\
\hline $850-52$ & 29.52 & 30.73 & 1.21 & 12.19 & 10.07 & 11.05 & 22.17 & 11.12 & Not diluted & 1.0000 \\
\hline $850-100$ & 29.20 & 30.25 & 1.05 & 10.52 & 10.02 & 11.04 & 20.67 & 9.63 & Not diluted & 1.0000 \\
\hline
\end{tabular}

${ }^{\mathrm{a}}$ A single RWS solution was passed through 3 filters into 3 bottles for separate analyses. 
Table 31. Test data for 7-day PCTs with heat-treated CWF samples

\begin{tabular}{|c|c|c|c|c|c|c|c|c|c|c|c|c|}
\hline \multirow{2}{*}{ Test no. } & \multirow{2}{*}{$\begin{array}{c}\text { CWF } \\
\text { mass, g }\end{array}$} & \multirow{2}{*}{$\begin{array}{l}\text { Water } \\
\text { mass, g }\end{array}$} & \multirow{2}{*}{$\mathrm{S} / \mathrm{V}, \mathrm{m}^{-1}$} & \multicolumn{4}{|c|}{ Test vessel, g } & \multirow{2}{*}{$\begin{array}{l}\mathrm{pH} \text { at } \\
25^{\circ} \mathrm{C}\end{array}$} & \multicolumn{3}{|c|}{ Solution bottle, $\mathrm{g}$} & \multirow{2}{*}{$\begin{array}{c}\text { Dilution } \\
\text { factor }\end{array}$} \\
\hline & & & & $\begin{array}{c}\text { Vessel } \\
\text { no. }\end{array}$ & Mass in & $\begin{array}{c}\text { Mass } \\
\text { out }\end{array}$ & Change & & tare & $\begin{array}{c}+ \\
\text { leachate } \\
\end{array}$ & $\begin{array}{c}+\mathrm{HNO}_{3}+ \\
\text { leachate }\end{array}$ & \\
\hline \multicolumn{13}{|c|}{ Long-term heat-treated CWF } \\
\hline $400-1 w$ & 0.2803 & 2.7615 & 2335 & 44 & 315.10 & 315.09 & -0.01 & 8.42 & 11.20 & 13.63 & 21.29 & 4.1523 \\
\hline $400-4 w$ & 0.7338 & 7.5268 & 2242 & 490 & 322.84 & 322.83 & -0.01 & 8.26 & 11.19 & 18.22 & 21.49 & 1.4651 \\
\hline $400-3 m$ & 0.2673 & 2.7632 & 2225 & 120 & 319.50 & 319.49 & -0.01 & 8.35 & 11.20 & 13.66 & 21.28 & 4.0976 \\
\hline $400-6 m$ & 1.1138 & 11.23 & 2281 & 734 & 336.82 & 336.82 & 0.00 & 8.66 & 11.16 & 21.51 & 29.79 & 1.8000 \\
\hline $400-1 y$ & 1.2172 & 12.22 & 2291 & 960 & 327.09 & 327.09 & 0.00 & 8.69 & 11.15 & 22.50 & 32.94 & 1.9198 \\
\hline $500-1 w$ & 0.1937 & 1.9819 & 2248 & 904 & 312.84 & 312.84 & 0.00 & 8.35 & 11.17 & 12.81 & 21.43 & 6.2561 \\
\hline $500-4 w$ & 0.7787 & 7.8187 & 2291 & 159 & 324.82 & 324.82 & 0.00 & 8.43 & 11.13 & 18.20 & 22.59 & 1.6209 \\
\hline $500-3 \mathrm{~m}$ & 0.5337 & 5.3813 & 2281 & 733 & 329.36 & 329.35 & -0.01 & 8.44 & 11.15 & 15.80 & 21.40 & 2.2043 \\
\hline $500-6 \mathrm{~m}$ & 1.2589 & 12.62 & 2294 & 755 & 329.16 & 329.15 & -0.01 & 8.79 & 11.13 & 22.76 & 32.68 & 1.8530 \\
\hline $500-1 y$ & 1.2443 & 12.43 & 2302 & 726 & 327.69 & 327.70 & 0.01 & 8.76 & 11.13 & 22.48 & 33.45 & 1.9665 \\
\hline \multicolumn{13}{|c|}{ Short-term heat-treated CWF } \\
\hline Pnoheat-1 & 1.01 & 10.11 & 2298 & 910 & 327.71 & 327.70 & -0.01 & 8.74 & 11.14 & 20.24 & 30.38 & 2.1143 \\
\hline Pnoheat-2 & 1.06 & 10.61 & 2298 & 760 & 327.55 & 327.55 & 0.00 & 8.72 & 11.12 & 20.52 & 30.18 & 2.0277 \\
\hline Pnoheat-3 & 1.16 & 11.61 & 2298 & 456 & 325.78 & 325.78 & 0.00 & 8.71 & 11.18 & 21.66 & 30.29 & 1.8235 \\
\hline P600-28 & 1.23 & 12.35 & 2291 & 819 & 324.25 & 324.26 & 0.01 & 8.71 & 11.10 & 22.45 & 30.74 & 1.7304 \\
\hline P600-52 & 1.21 & 12.10 & 2300 & 906 & 327.75 & 327.76 & 0.01 & 8.75 & 11.14 & 22.15 & 30.20 & 1.7312 \\
\hline P600-100 & 0.93 & 9.35 & 2288 & 920 & 322.89 & 322.90 & 0.01 & 8.66 & 11.20 & 19.78 & 30.14 & 2.2075 \\
\hline P700-28 & 1.20 & 12.00 & 2300 & 749 & 324.57 & 324.57 & 0.00 & 8.77 & 11.14 & 22.11 & 30.28 & 1.7448 \\
\hline P700-52 & 1.30 & 13.02 & 2296 & 953 & 327.26 & 327.27 & 0.01 & 8.79 & 11.19 & 22.43 & 30.42 & 1.7109 \\
\hline P700-100 & 0.95 & 9.52 & 2295 & 420 & 326.37 & 326.37 & 0.00 & 8.72 & 11.10 & 19.66 & 30.09 & 2.2185 \\
\hline P800-28 & 1.28 & 12.81 & 2298 & 726 & 326.13 & 326.14 & 0.01 & 8.71 & 11.16 & 22.74 & 30.29 & 1.6520 \\
\hline P800-52 & 1.42 & 14.20 & 2300 & 490 & 328.94 & 328.94 & 0.00 & 8.77 & 11.18 & 23.65 & 30.23 & 1.5277 \\
\hline P800-100 & 1.21 & 12.10 & 2300 & 159 & 329.13 & 329.13 & 0.00 & 8.72 & 11.14 & 21.97 & 30.89 & 1.8236 \\
\hline P850-28 & 1.22 & 12.21 & 2298 & 755 & 328.92 & 328.93 & 0.01 & 8.79 & 11.21 & 22.20 & 30.44 & 1.7498 \\
\hline P850-52 & 1.12 & 11.20 & 2300 & 44 & 326.25 & 326.25 & 0.00 & 8.67 & 11.12 & 21.17 & 30.21 & 1.8995 \\
\hline P850-100 & 1.02 & 10.21 & 2298 & 904 & 333.20 & 333.21 & 0.01 & 8.78 & 11.16 & 20.25 & 30.19 & 2.0935 \\
\hline PLRM-4 & 1.14 & 11.42 & 1996 & 732 & 337.22 & 337.24 & 0.02 & 10.69 & 11.15 & 21.51 & 30.79 & 1.8958 \\
\hline PLRM-5 & 1.05 & 10.53 & 1994 & 733 & 325.11 & 325.12 & 0.01 & 10.68 & 11.10 & 20.71 & 30.82 & 2.0520 \\
\hline PLRM-6 & 1.12 & 11.23 & 1995 & 960 & 326.36 & 326.38 & 0.02 & 10.70 & 11.16 & 21.50 & 30.37 & 1.8578 \\
\hline PBL-3 & 0.00 & 12.38 & & 970 & 324.74 & 324.74 & 0.00 & Not measured & 11.18 & 23.38 & 23.43 & 1.0041 \\
\hline PBL-4 & 0.00 & 12.28 & & 743 & 325.87 & 325.89 & 0.02 & Not measured & 11.13 & 23.23 & 23.30 & 1.0058 \\
\hline
\end{tabular}


Table 32. Results of RWS tests with short-term and long-term heat-treated CWF samples

\begin{tabular}{|c|c|c|c|}
\hline Material ID & $\begin{array}{c}\text { Measured } \mathrm{Cl}^{-}, \\
\mathrm{mg} / \mathrm{L}\end{array}$ & $\begin{array}{c}\mathrm{Cl}^{-} \text {in RWS, } \\
\mathrm{mg} / \mathrm{L}\end{array}$ & $N L(\mathrm{Cl}), \mathrm{g} / \mathrm{m}^{2}$ \\
\hline \multicolumn{4}{|c|}{ Long-term heat-treated CWF } \\
\hline $400-1 w$ & 60.7 & 200 & 1.99 \\
\hline $400-4 w$ & 136 & 178 & 1.83 \\
\hline $400-3 m$ & 34.0 & 119 & 1.18 \\
\hline $400-6 m$ & 226 & 226 & 2.25 \\
\hline $400-1 y$ & 251 & 251 & 2.49 \\
\hline $500-1 w$ & 44.4 & 226 & 2.21 \\
\hline $500-4 w$ & 190 & 243 & 2.41 \\
\hline $500-3 m$ & 74.2 & 119 & 1.33 \\
\hline $500-6 m$ & 247 & 247 & 2.45 \\
\hline $500-1 y$ & 281 & 281 & 2.79 \\
\hline \multicolumn{4}{|c|}{ Short-term heat-treated CWF } \\
\hline $600-28$ & 261 & 261 & 2.10 \\
\hline $600-52$ & 301 & 301 & 2.98 \\
\hline $600-100$ & 354 & 354 & 4.44 \\
\hline $700-28$ & 270 & 270 & 2.67 \\
\hline $700-52$ & 285 & 285 & 2.82 \\
\hline $700-100$ & 206 & 206 & 2.04 \\
\hline $800-28$ & 233 & 233 & 2.31 \\
\hline $800-52$ & 199 & 199 & 1.98 \\
\hline $800-100$ & 151 & 151 & 1.50 \\
\hline $850-28$ & 244 & 244 & 2.41 \\
\hline $850-52$ & 224 & 224 & 2.23 \\
\hline $850-100$ & 132 & 132 & 1.31 \\
\hline No heat-1 & 303 & 303 & 3.00 \\
\hline No heat-2 & 308 & 308 & 3.05 \\
\hline No heat-3 & 306 & 306 & 3.03 \\
\hline
\end{tabular}


Table 33. Results of 7-day PCTs with short-term and long-term heat-treated CWF materials ${ }^{\mathrm{a}}$

\begin{tabular}{|c|c|c|c|c|c|c|c|}
\hline & $\mathrm{Al}, \mathrm{mg} / \mathrm{L}$ & $\mathrm{B}, \mathrm{mg} / \mathrm{L}$ & $N L(\mathrm{~B}), \mathrm{g} / \mathrm{m}^{2}$ & $\mathrm{Na}, \mathrm{mg} / \mathrm{L}$ & $N L(\mathrm{Na}), \mathrm{g} / \mathrm{m}^{2}$ & $\mathrm{Si}, \mathrm{mg} / \mathrm{L}$ & $N L(\mathrm{Si}), \mathrm{g} / \mathrm{m}^{2}$ \\
\hline \multicolumn{8}{|c|}{ Long-term heat-treated CWF } \\
\hline $400-1 w$ & 13.7 & 0.752 & 0.0219 & 23.7 & 0.0867 & 16.8 & 0.0819 \\
\hline $400-4 w$ & 10.6 & 1.83 & 0.0551 & 18.4 & 0.0700 & 12.2 & 0.0594 \\
\hline $400-3 m$ & 12.4 & 0.902 & 0.0263 & 23.6 & 0.0865 & 16.1 & 0.0788 \\
\hline $400-6 m$ & 7.05 & 0.807 & 0.0235 & 10.3 & 0.0378 & 10.1 & 0.0493 \\
\hline $400-1 y$ & 7.61 & 0.868 & 0.0253 & 10.7 & 0.0392 & 11.6 & 0.0566 \\
\hline $500-1 w$ & 10.3 & 0.902 & 0.0259 & 17.5 & 0.0634 & 14.0 & 0.0683 \\
\hline $500-4 w$ & 12.4 & 1.45 & 0.0420 & 20.7 & 0.0759 & 16.0 & 0.0781 \\
\hline $500-3 m$ & 12.0 & 1.20 & 0.0392 & 18.5 & 0.0763 & 16.7 & 0.0814 \\
\hline $500-6 \mathrm{~m}$ & 8.24 & 1.06 & 0.0308 & 9.62 & 0.0353 & 12.7 & 0.0620 \\
\hline $500-1 y$ & 6.44 & 0.868 & 0.0253 & 9.28 & 0.0340 & 9.68 & 0.0472 \\
\hline \multicolumn{8}{|c|}{ Short-term heat-treated CWF } \\
\hline No heat-1 & 26.4 & 1.71 & 0.0493 & 27.7 & 0.101 & 33.6 & 0.0713 \\
\hline No heat-2 & 25.8 & 1.73 & 0.0498 & 26.6 & 0.0971 & 33.7 & 0.0714 \\
\hline No heat-3 & 23.9 & 1.62 & 0.0468 & 24.8 & 0.0906 & 31.4 & 0.0666 \\
\hline Average: & & & 0.0486 & & 0.0963 & & 0.0698 \\
\hline $600-28$ & 22.7 & 1.70 & 0.0491 & 27.3 & 0.100 & 30.6 & 0.0652 \\
\hline $600-52$ & 19.9 & 1.52 & 0.0437 & 19.9 & 0.0727 & 26.5 & 0.0562 \\
\hline $600-100$ & 20.9 & 1.57 & 0.0456 & 22.1 & 0.0810 & 27.6 & 0.0588 \\
\hline $700-28$ & 26.0 & 1.56 & 0.0450 & 29.0 & 0.106 & 33.8 & 0.0718 \\
\hline $700-52$ & 24.8 & 1.64 & 0.0474 & 28.7 & 0.105 & 32.2 & 0.0683 \\
\hline $700-100$ & 26.8 & 1.72 & 0.0498 & 29.7 & 0.109 & 33.3 & 0.0707 \\
\hline $800-28$ & 22.6 & 1.50 & 0.0431 & 26.1 & 0.0954 & 29.4 & 0.0624 \\
\hline $800-52$ & 22.9 & 1.44 & 0.0414 & 23.5 & 0.0859 & 29.3 & 0.0622 \\
\hline $800-100$ & 24.3 & 1.48 & 0.0427 & 24.4 & 0.0892 & 30.5 & 0.0646 \\
\hline $850-28$ & 25.9 & 1.60 & 0.0460 & 28.2 & 0.103 & 33.9 & 0.0720 \\
\hline $850-52$ & 21.3 & 1.47 & 0.0422 & 29.3 & 0.107 & 28.7 & 0.0608 \\
\hline $850-100$ & 27.8 & 1.46 & 0.0422 & 29.3 & 0.107 & 35.0 & 0.0742 \\
\hline LRM-4 & 11.8 & 20.7 & 0.424 & 120 & 0.406 & 65.6 & 0.129 \\
\hline LRM-5 & 10.1 & 18.9 & 0.389 & 106 & 0.360 & 56.8 & 0.113 \\
\hline LRM-6 & 12.0 & 20.8 & 0.427 & 119 & 0.403 & 64.5 & 0.127 \\
\hline Average: & 11.33 & 20.1 & 0.413 & 115 & 0.390 & 62.3 & 0.123 \\
\hline BL-3 & $<0.02$ & 0.01 & & $<0.02$ & & 0.18 & \\
\hline BL-4 & $<0.02$ & 0.01 & & $<0.02$ & & 0.46 & \\
\hline
\end{tabular}

${ }^{\mathrm{a}}$ For CWF: $f(\mathrm{~B})=0.0150 ; f(\mathrm{Na})=0.119 ; f(\mathrm{Si})=0.205$; for LRM: $f(\mathrm{~B})=0.0244, f(\mathrm{Na})=0.148$, and $f(\mathrm{Si})=0.253$. 
Table 34. Calculated crystalline phase composition based on stoichiometry

\begin{tabular}{|l|c|c|c|c|c|c|c|}
\hline & S1A & S2B & S3A & S3C & S3E & S4A & S5B \\
\hline Cl per formula & 1.5 & 2.32 & 3.42 & 3.42 & 3.42 & 4.08 & 5.04 \\
\hline Moles sodalite & 0.75 & 1.16 & 1.71 & 1.71 & 1.71 & 2.04 & 2.52 \\
\hline Moles nepheline & 1.88 & 1.26 & 0.44 & 0.44 & 0.44 & 0 & 0 \\
\hline Moles excess halite & 0 & 0 & 0 & 0 & 0 & 0.08 & 1.04 \\
\hline g sodalite & 726.92 & 1124.30 & 1657.38 & 1657.38 & 1657.38 & 1977.23 & 2442.45 \\
\hline g nepheline & 1065.44 & 715.97 & 247.18 & 247.18 & 247.18 & 0 & 0 \\
\hline g excess halite & 0 & 0 & 0 & 0 & 0 & 4.68 & 60.78 \\
\hline & & & & & & & \\
\hline Mass\% sodalite & 41 & 61 & 87 & 87 & 87 & 99.8 & 97.6 \\
\hline Mass\% nepheline & 59 & 39 & 13 & 13 & 13 & 0 & 0 \\
\hline Mass\% halite & 0 & 0 & 0 & 0 & 0 & 0.20 & 2.4 \\
\hline
\end{tabular}

Table 35. Calculated fractions of $\mathrm{B}, \mathrm{Na}$, and $\mathrm{Si}$ in binder glass and sodalite, and mass fractions in $\mathrm{CWF}$

\begin{tabular}{|c|c|c|c|c|c|c|c|c|c|}
\hline & \multicolumn{3}{|c|}{ Binder glass } & \multicolumn{3}{c|}{ Sodalite } & \multicolumn{3}{c|}{ CWF } \\
\hline & $\mathrm{B}$ & $\mathrm{Na}$ & $\mathrm{Si}$ & $\mathrm{B}$ & $\mathrm{Na}$ & $\mathrm{Si}$ & $f(\mathrm{~B})$ & $f(\mathrm{Na})$ & $f(\mathrm{Si})$ \\
\hline S1A & 1.000 & 0.074 & 0.345 & 0.000 & 0.926 & 0.655 & 0.014 & 0.130 & 0.203 \\
\hline S2C & 1.000 & 0.074 & 0.345 & 0.000 & 0.926 & 0.655 & 0.015 & 0.128 & 0.204 \\
\hline S3A & 1.000 & 0.074 & 0.345 & 0.000 & 0.926 & 0.655 & 0.014 & 0.123 & 0.197 \\
\hline S3C & 1.000 & 0.074 & 0.345 & 0.000 & 0.926 & 0.655 & 0.015 & 0.125 & 0.200 \\
\hline S3E & 1.000 & 0.074 & 0.345 & 0.000 & 0.926 & 0.655 & 0.015 & 0.111 & 0.192 \\
\hline S4A & 1.000 & 0.074 & 0.345 & 0.000 & 0.926 & 0.655 & 0.015 & 0.122 & 0.201 \\
\hline S5B & 1.000 & 0.074 & 0.345 & 0.000 & 0.926 & 0.655 & 0.015 & 0.116 & 0.203 \\
\hline G1A & 1.000 & 0.056 & 0.283 & 0.000 & 0.944 & 0.717 & 0.012 & 0.126 & 0.198 \\
\hline G2A & 1.000 & 0.065 & 0.314 & 0.000 & 0.935 & 0.686 & 0.013 & 0.129 & 0.196 \\
\hline G4A & 1.000 & 0.083 & 0.375 & 0.000 & 0.917 & 0.625 & 0.017 & 0.123 & 0.217 \\
\hline G5A & 1.000 & 0.093 & 0.403 & 0.000 & 0.907 & 0.597 & 0.018 & 0.117 & 0.208 \\
\hline
\end{tabular}

Table 36. Data for standard additions of $\mathrm{NaCl}$ to CWF material PC10402

\begin{tabular}{|l|c|c|c|}
\hline & Salt mix 1 & Salt mix 2 & Salt mix 1 \\
\hline Vial tare, g & 16.8086 & 16.7291 & 16.7348 \\
\hline Mass vial + CWF, g & 17.5848 & 17.7471 & 17.3277 \\
\hline Mass vial + CWF +salt, g & 17.6330 & 17.7995 & 17.3784 \\
\hline Mass vial after heating, g & 17.6306 & 17.7971 & 17.3764 \\
\hline Calculated mass CWF, g & 0.7762 & 1.0180 & 0.5929 \\
\hline Calculated mass dried salt, g & 0.0458 & 0.0500 & 0.0487 \\
\hline Mass visible salt removed by sieving, g & 0.0010 & 0.0013 & 0.0020 \\
\hline Total mass after sieving, g & 17.6061 & 17.7656 & 17.3451 \\
\hline Final mass - mass after heating, g & -0.0245 & -0.0315 & -0.0313 \\
\hline Adjusted mass CWF, g & 0.7527 & 0.9878 & 0.5636 \\
\hline Adjusted mass salt, g & 0.0448 & 0.0487 & 0.0467 \\
\hline Mass\% salt & $5.62 \%$ & $4.70 \%$ & $7.65 \%$ \\
\hline
\end{tabular}


Table 37. Results of XRD analyses of source CWF material PC10402 with added $\mathrm{NaCl}$

\begin{tabular}{|c|c|c|c|c|c|c|c|c|c|c|c|c|c|c|}
\hline \multicolumn{3}{|c|}{ CWF PC10402 ${ }^{a}$} & \multicolumn{3}{|c|}{$\mathrm{CWF}+4.57 \% \mathrm{NaCl}$} & \multicolumn{3}{|c|}{$\mathrm{CWF}+5.46 \% \mathrm{NaCl}$} & \multicolumn{3}{|c|}{$\mathrm{CWF}+7.30 \% \mathrm{NaCl}$} & \multicolumn{3}{|c|}{ Reference phases } \\
\hline$d(\AA)$ & $\begin{array}{c}\text { I\% peak } \\
\text { area }\end{array}$ & $\begin{array}{c}\text { I\% peak } \\
\text { height }\end{array}$ & $d(\AA)$ & $\begin{array}{c}1 \% \text { peak } \\
\text { area }\end{array}$ & $\begin{array}{c}1 \% \text { peak } \\
\text { height }\end{array}$ & $d(\AA)$ & $\begin{array}{c}1 \% \text { peak } \\
\text { area }\end{array}$ & $\begin{array}{c}\text { I\% peak } \\
\text { height }\end{array}$ & $d(\AA)$ & $\begin{array}{c}1 \% \text { peak } \\
\text { area }\end{array}$ & $\begin{array}{c}1 \% \text { peak } \\
\text { height }\end{array}$ & ID & $d(\AA)$ & $\begin{array}{c}1 \% \text { peak } \\
\text { height }\end{array}$ \\
\hline \multirow[t]{4}{*}{6.2766} & 23.8 & 24.7 & 6.3478 & 26.6 & 25.2 & 6.3651 & 28.0 & 25.7 & 6.3561 & 27.3 & 24.7 & Sodalite & 6.28 & 40 \\
\hline & & & & & & & & & & & & & 5.76 & \\
\hline & & & & & & & & & & & & Nepheline & 5.0058 & 10 \\
\hline & & & & & & & & & & & & & 4.86 & \\
\hline \multirow[t]{4}{*}{4.4326} & 6.7 & 7.0 & 4.4714 & 7.3 & 6.7 & 4.476 & 7.8 & 6.8 & 4.4755 & 7.3 & 6.8 & Sodalite & 4.44 & 5 \\
\hline & & & & & & & & & & & & & 4.20 & \\
\hline & & & & & & & & & & & & Nepheline & 4.3335 & 35 \\
\hline & & & & & & & & & & & & Nepheline & 4.1766 & 80 \\
\hline \multirow[t]{5}{*}{3.9629} & 1.3 & 1.8 & 3.9972 & 1.2 & 1.0 & 4.0043 & 1.5 & 1.1 & 3.9974 & 1.3 & 1.0 & Sodalite & 3.97 & 1 \\
\hline & & & & & & & & & & & & & 3.9 & \\
\hline & & & & & & 3.8804 & 0.3 & 0.2 & & & & Nepheline & 3.8438 & 100 \\
\hline & & & & & & & & & & & & Nepheline & 3.7614 & 2 \\
\hline & & & & & & & & & & & & & 3.70 & \\
\hline \multirow[t]{4}{*}{3.6215} & 100 & 100 & 3.6448 & 100 & 100 & 3.648 & 100 & 100 & 3.645 & 100 & 100 & Sodalite & 3.624 & 100 \\
\hline & & & 3.6023 & 1.6 & 0.9 & 3.6099 & 1.1 & 0.8 & 3.6071 & 1.1 & 0.8 & & 3.58 & \\
\hline & & & & & & & & & & & & & 3.53 & \\
\hline & & & & & & & & & & & & Nepheline & 3.2731 & 70 \\
\hline \multirow[t]{5}{*}{3.2592} & 1.0 & 1.0 & 3.2783 & 1.8 & 1.6 & 3.2828 & 2.4 & 2.1 & 3.2804 & 3.8 & 2.5 & Halite & 3.26 & 13 \\
\hline & & & & & & 3.1592 & 0.2 & 0.2 & & & & & 3.15 & \\
\hline & & & & & & & & & & & & Nepheline & 3.0461 & 18 \\
\hline & & & & & & & & & & & & Nepheline & 3.0059 & 100 \\
\hline & & & & & & & & & & & & Nepheline & 2.8864 & 35 \\
\hline 2.8237 & 5.6 & 17.5 & 2.8377 & 17.3 & 15.5 & 2.8395 & 24.9 & 20.6 & 2.8377 & 27.4 & 21.2 & Halite & 2.821 & 100 \\
\hline \multirow[t]{2}{*}{2.8047} & 9.2 & 15.3 & 2.8168 & 11.9 & 9.1 & 2.8202 & 12.0 & 9.0 & 2.8184 & 11.0 & 8.9 & Sodalite & 2.807 & 8 \\
\hline & & & & & & 2.7383 & 0.4 & 0.3 & & & & & 2.70 & \\
\hline \multirow[t]{4}{*}{2.5601} & 18.4 & 19.4 & 2.5701 & 20.0 & 20.9 & 2.5729 & 20.1 & 20.1 & 2.5714 & 20.2 & 20.2 & Sodalite & 2.563 & 16 \\
\hline & & & & & & 2.5504 & 0.3 & 0.3 & 2.5474 & 0.4 & 0.2 & & 2.54 & \\
\hline & & & & & & & & & & & & Nepheline & 2.5000 & 14 \\
\hline & & & & & & & & & & & & Nepheline & 2.4007 & 10 \\
\hline \multirow[t]{2}{*}{2.3696} & 18.6 & 20.5 & 2.378 & 21.5 & 22.3 & 2.3805 & 20.4 & 20.4 & 2.3792 & 21.3 & 21.2 & Sodalite & 2.373 & 16 \\
\hline & & & & & & & & & & & & Nepheline & 2.3395 & 35 \\
\hline
\end{tabular}


Table 37. (continued)

\begin{tabular}{|c|c|c|c|c|c|c|c|c|c|c|c|c|c|c|}
\hline \multicolumn{3}{|c|}{ CWF PC10402 } & \multicolumn{3}{|c|}{$\mathrm{CWF}+4.57 \% \mathrm{NaCl}$} & \multicolumn{3}{|c|}{$\mathrm{CWF}+5.46 \% \mathrm{NaCl}$} & \multicolumn{3}{|c|}{$\mathrm{CWF}+7.30 \% \mathrm{NaCl}$} & \multicolumn{3}{|c|}{ Reference phases } \\
\hline \multirow[t]{3}{*}{$d(\AA)$} & $\begin{array}{c}1 \% \text { peak } \\
\text { area }\end{array}$ & $\begin{array}{c}1 \% \text { peak } \\
\text { height }\end{array}$ & $d(\AA)$ & $\begin{array}{c}1 \% \text { peak } \\
\text { area }\end{array}$ & $\begin{array}{c}\text { I\% peak } \\
\text { height }\end{array}$ & $d(\AA \AA)$ & $\begin{array}{c}1 \% \text { peak } \\
\text { area }\end{array}$ & $\begin{array}{c}\text { I\% peak } \\
\text { height }\end{array}$ & $d(\AA)$ & $\begin{array}{c}1 \% \text { peak } \\
\text { area }\end{array}$ & $\begin{array}{c}1 \% \text { peak } \\
\text { height }\end{array}$ & ID & $d(\AA)$ & $\begin{array}{c}\text { I\% peak } \\
\text { height }\end{array}$ \\
\hline & & & & & & & & & & & & \begin{tabular}{|l|} 
Nepheline \\
\end{tabular} & 2.3074 & 25 \\
\hline & & & & & & & & & & & & & 2.289 & \\
\hline \multirow[t]{4}{*}{2.2159} & 1.1 & 1.6 & 2.2234 & 1.6 & 1.3 & 2.2255 & 1.3 & 1.3 & 2.2235 & 1.3 & 1.3 & Sodalite & 2.219 & 1 \\
\hline & & & & & & & & & & & & Nepheline & 2.163 & 5 \\
\hline & & & & & & & & & & & & Nepheline & 2.1188 & 7 \\
\hline & & & & & & & & & & & & Nepheline & 2.0938 & 5 \\
\hline \multirow[t]{3}{*}{2.0897} & 28.2 & 30.9 & 2.0961 & 33.5 & 34.0 & 2.098 & 31.5 & 30.6 & 2.097 & 32.3 & 31.1 & Sodalite & 2.093 & 20 \\
\hline & & & & & & & & & & & & & 2.074 & \\
\hline & & & & & & & & & & & & & 2.064 & \\
\hline 1.9954 & 2.4 & 6.0 & 2.0019 & 10.9 & 10.0 & 2.0035 & 11.7 & 10.7 & 2.0027 & 14.0 & 12.2 & Halite & 1.994 & 55 \\
\hline \multirow[t]{2}{*}{1.9827} & 4.2 & 6.5 & 1.9877 & 5.1 & 5.5 & 1.9902 & 5.6 & 4.7 & 1.9886 & 5 & 5 & Sodalite & 1.985 & 3 \\
\hline & & & & & & & & & & & & Nepheline & 1.9313 & 6 \\
\hline \multirow[t]{2}{*}{1.8901} & 3.6 & 3.7 & 1.8946 & 4.6 & 4.6 & 1.8967 & 4.1 & 3.8 & 1.8953 & 4.9 & 4.1 & Sodalite & 1.893 & 3 \\
\hline & & & & & & & & & & & & Nepheline & 1.8411 & 2 \\
\hline \multirow[t]{2}{*}{1.8093} & 3.2 & 3.7 & 1.8138 & 4.0 & 4.0 & 1.8152 & 3.6 & 3.5 & 1.8145 & 3.9 & 3.6 & Sodalite & 1.8122 & 2 \\
\hline & & & & & & & & & & & & Nepheline & 1.7923 & 5 \\
\hline \multirow[t]{4}{*}{1.7385} & 3.8 & 3.7 & 1.7422 & 4.3 & 4.2 & 1.744 & 4.0 & 3.6 & 1.7428 & 4.1 & 3.6 & Sodalite & 1.7413 & 2 \\
\hline & & & & & & & & & & & & & 1.72 & \\
\hline & & & 1.7061 & 0.5 & 0.4 & 1.7072 & 0.7 & 0.5 & 1.706 & 0.8 & 0.5 & Nepheline & 1.6942 & 5 \\
\hline & & & 1.6478 & 0.7 & 0.5 & 1.651 & 0.3 & 0.3 & 1.6494 & 0.5 & 0.4 & Nepheline & 1.6346 & 6 \\
\hline 1.6279 & 0.6 & 1.1 & 1.6332 & 2.5 & 2.4 & 1.6343 & 4.4 & 4.1 & 1.6332 & 4.6 & 3.8 & Halite & 1.628 & 15 \\
\hline \multirow[t]{3}{*}{1.618} & 2.2 & 3.5 & 1.6216 & 3.5 & 3.5 & 1.6227 & 3.8 & 3.1 & 1.6221 & 3.9 & 2.8 & Sodalite & 1.621 & 2 \\
\hline & & & & & & & & & & & & Nepheline & 1.615 & 8 \\
\hline & & & & & & & & & & & & Nepheline & 1.6002 & 4 \\
\hline \multirow[t]{2}{*}{1.5667} & 8.3 & 11.1 & 1.5696 & 13.7 & 13.1 & 1.571 & 12.1 & 11.1 & 1.5705 & 12.8 & 11.5 & Sodalite & 1.5696 & 5 \\
\hline & & & & & & & & & & & & Nepheline & 1.5614 & 14 \\
\hline 1.5203 & 4.4 & 6.3 & 1.5227 & 7.0 & 6.5 & 1.524 & 6.2 & 5.5 & 1.5231 & 6.8 & 5.6 & Sodalite & 1.5227 & 3 \\
\hline \multirow[t]{4}{*}{1.4772} & 6.6 & 9.8 & 1.4797 & 10.4 & 9.9 & 1.4806 & 9.8 & 8.8 & 1.4801 & 10 & 8.8 & Sodalite & 1.4797 & 4 \\
\hline & & & & & & & & & & & & & 1.474 & \\
\hline & & & & & & & & & & & & Nepheline & 1.4687 & 5 \\
\hline & & & & & & & & & & & & & 1.463 & \\
\hline
\end{tabular}


Table 37. (continued)

\begin{tabular}{|c|c|c|c|c|c|c|c|c|c|c|c|c|c|c|}
\hline \multicolumn{3}{|c|}{ CWF PC10402 } & \multicolumn{3}{|c|}{$\mathrm{CWF}+4.57 \% \mathrm{NaCl}$} & \multicolumn{3}{|c|}{$\mathrm{CWF}+5.46 \% \mathrm{NaCl}$} & \multicolumn{3}{|c|}{$\mathrm{CWF}+7.30 \% \mathrm{NaCl}$} & \multicolumn{3}{|c|}{ Reference phases } \\
\hline & & & $d(\AA)$ & $\begin{array}{c}1 \% \text { peak } \\
\text { area }\end{array}$ & $\begin{array}{c}1 \% \text { peak } \\
\text { height }\end{array}$ & ID & $d(\AA)$ & $\begin{array}{c}\text { I\% peak } \\
\text { area }\end{array}$ & $\begin{array}{c}1 \% \text { peak } \\
\text { height }\end{array}$ & ID & $d(\AA)$ & $\begin{array}{c}1 \% \text { peak } \\
\text { area }\end{array}$ & $\begin{array}{c}\text { I\% peak } \\
\text { height }\end{array}$ & ID \\
\hline & & & & & & & & & & & & Nepheline & 1.4555 & 3 \\
\hline \multirow[t]{3}{*}{1.4376} & 7.3 & 10.7 & 1.44 & 11.4 & 10.8 & 1.4411 & 10.3 & 9.2 & 1.4404 & 10.8 & 9.6 & Sodalite & 1.4404 & 5 \\
\hline & & & & & & & & & & & & Nepheline & 1.4282 & 7 \\
\hline & & & 1.4132 & 1.3 & 1.3 & 1.4143 & 1.3 & 1.3 & 1.4139 & 1.8 & 1.5 & Halite & 1.41 & 6 \\
\hline \multirow[t]{2}{*}{1.401} & 0.7 & 0.5 & 1.4034 & 1.1 & 0.8 & 1.4041 & 0.9 & 0.6 & 1.4045 & 0.9 & 0.6 & Sodalite & 1.4038 & 1 \\
\hline & & & & & & & & & & & & Nepheline & 1.3865 & 6 \\
\hline \multirow[t]{2}{*}{1.3676} & 2.6 & 3.9 & 1.3697 & 4.8 & 4.3 & 1.3704 & 4.1 & 3.7 & 1.37 & 4.4 & 3.7 & Sodalite & 1.3699 & 2 \\
\hline & & & 1.352 & 0.2 & 0.3 & & & & & & & & 1.352 & \\
\hline \multirow[t]{2}{*}{1.3363} & 3.1 & 4.2 & 1.3379 & 4.9 & 4.2 & 1.3389 & 4.7 & 3.8 & 1.3383 & 4.4 & 3.7 & Sodalite & 1.3385 & 2 \\
\hline & & & & & & & & & & & & & 1.34 & \\
\hline \multirow[t]{2}{*}{1.3067} & 2.7 & 4.2 & 1.3086 & 4.7 & 4.1 & 1.3092 & 4.2 & 3.7 & 1.3086 & 3.9 & 3.3 & Sodalite & 1.3091 & 2 \\
\hline & & & & & & & & & & & & & 1.31 & \\
\hline \multirow[t]{5}{*}{1.2793} & 2.0 & 2.9 & 1.2808 & 3.3 & 2.8 & 1.2814 & 3.2 & 2.6 & 1.2811 & 3.0 & 2.5 & Sodalite & 1.2814 & 2 \\
\hline & & & & & & & & & & & & Nepheline & 1.279 & 6 \\
\hline & & & 1.2636 & 3.1 & 2.6 & 1.2642 & 4.9 & 3.8 & 1.2639 & 3.9 & 2.7 & Sodalite & 1.2684 & 1 \\
\hline & & & & & & & & & & & & Sodalite & 1.2555 & 1 \\
\hline & & & & & & & & & & & & Nepheline & 1.2347 & 4 \\
\hline 1.229 & 0.5 & 0.9 & 1.2304 & 1.1 & 0.8 & 1.2306 & 1.1 & 0.8 & 1.2309 & 1.1 & 0.7 & & 1.23 & \\
\hline 1.2263 & 0.4 & 0.8 & & & & & & & & & & & & \\
\hline 1.2057 & 5.9 & 8.5 & 1.2074 & 10.3 & 8.6 & 1.2079 & 9.5 & 7.1 & 1.2076 & 9.5 & 7.6 & Sodalite & 1.2081 & 3 \\
\hline
\end{tabular}

${ }^{\mathrm{a}}$ Results from Analysis 1 . 
Table 38. Calculated concentrations of halite in various CWF samples, in mass $\%{ }^{\mathrm{a}}$

\begin{tabular}{|c|c|c|c|c|c|c|c|}
\hline \multicolumn{8}{|c|}{ Salt-loaded CWF products } \\
\hline $\begin{array}{c}d \text {-spacing, } \\
\AA\end{array}$ & S1A & S1B & S2C & S3A & S3B & S3C & S3E \\
\hline 2.821 & $<0.03$ & $<0.03$ & $<0.03$ & 2.40 & 3.21 & 2.20 & 2.33 \\
\hline 1.994 & $<0.05$ & $<0.05$ & $<0.05$ & 1.07 & 1.41 & 1.36 & 1.02 \\
\hline $\begin{array}{c}d \text {-spacing, } \\
\AA\end{array}$ & S4A & S5B & G1A & G2A & G4A & G5A & \\
\hline 2.821 & 2.50 & 2.96 & 1.94 & 1.93 & 2.42 & 1.60 & \\
\hline 1.994 & 1.56 & 2.63 & 1.77 & 1.86 & 1.13 & 1.64 & \\
\hline \multicolumn{8}{|c|}{ Long-term heat-treated CWF samples } \\
\hline $\begin{array}{c}d \text {-spacing, } \\
\AA\end{array}$ & $\begin{array}{l}400^{\circ} \mathrm{C} \\
1 \text { week }\end{array}$ & $\begin{array}{l}400^{\circ} \mathrm{C} \\
4 \text { weeks }\end{array}$ & $\begin{array}{l}400^{\circ} \mathrm{C} \\
3 \text { months }\end{array}$ & $\begin{array}{l}400^{\circ} \mathrm{C} \\
6 \text { months }\end{array}$ & $\begin{array}{c}400^{\circ} \mathrm{C} \\
1 \text { year }\end{array}$ & & \\
\hline 2.821 & $\mathrm{nr}^{\mathrm{b}}$ & 3.72 & 1.49 & 2.60 & 3.13 & & \\
\hline 1.994 & 2.09 & 2.43 & 2.00 & 1.51 & 2.34 & & \\
\hline $\begin{array}{c}d \text {-spacing, } \\
\AA\end{array}$ & $\begin{array}{l}500^{\circ} \mathrm{C} \\
1 \text { week }\end{array}$ & $\begin{array}{l}500^{\circ} \mathrm{C} \\
4 \text { weeks }\end{array}$ & $\begin{array}{l}500^{\circ} \mathrm{C} \\
3 \text { months }\end{array}$ & $\begin{array}{l}500^{\circ} \mathrm{C} \\
6 \text { months }\end{array}$ & $\begin{array}{c}500^{\circ} \mathrm{C} \\
1 \text { year }\end{array}$ & & \\
\hline 2.821 & $\mathrm{nr}$ & 1.74 & 1.92 & 3.51 & 1.72 & & \\
\hline 1.994 & 2.04 & 1.90 & 1.70 & 2.39 & 1.70 & & \\
\hline \multicolumn{8}{|c|}{ Short-term heat-treated CWF samples } \\
\hline $\begin{array}{c}d \text {-spacing, } \\
\AA\end{array}$ & $\begin{array}{c}600^{\circ} \mathrm{C} \\
28 \text { hours }\end{array}$ & $\begin{array}{c}600^{\circ} \mathrm{C} \\
52 \text { hours }\end{array}$ & $\begin{array}{c}600^{\circ} \mathrm{C} \\
100 \text { hours }\end{array}$ & $\begin{array}{c}700^{\circ} \mathrm{C} \\
28 \text { hours }\end{array}$ & $\begin{array}{c}700^{\circ} \mathrm{C} \\
52 \text { hours }\end{array}$ & $\begin{array}{c}700^{\circ} \mathrm{C} \\
100 \text { hours }\end{array}$ & \\
\hline 2.821 & 2.98 & 2.96 & 2.20 & 1.24 & 2.02 & 1.67 & \\
\hline 1.994 & 1.51 & 2.19 & 2.24 & 1.65 & 1.07 & 1.02 & \\
\hline $\begin{array}{c}d \text {-spacing, } \\
\AA\end{array}$ & $\begin{array}{c}800^{\circ} \mathrm{C} \\
28 \text { hours }\end{array}$ & $\begin{array}{c}800^{\circ} \mathrm{C} \\
52 \text { hours }\end{array}$ & $\begin{array}{c}800{ }^{\circ} \mathrm{C} \\
100 \text { hours }\end{array}$ & $\begin{array}{c}850^{\circ} \mathrm{C} \\
28 \text { hours }\end{array}$ & $\begin{array}{c}850^{\circ} \mathrm{C} \\
52 \text { hours }\end{array}$ & $\begin{array}{c}850^{\circ} \mathrm{C} \\
100 \text { hours }\end{array}$ & \\
\hline 2.821 & 2.91 & 2.60 & 1.77 & 1.11 & 2.35 & 2.63 & \\
\hline 1.994 & 0.92 & 0.58 & 0.78 & 1.46 & 1.22 & 1.27 & \\
\hline \multicolumn{8}{|c|}{ Replicate analyses of CWF material PC10402 } \\
\hline $\begin{array}{c}d \text {-spacing, } \\
\AA\end{array}$ & Analysis 1 & Analysis 2 & Analysis 3 & Analysis 4 & Analysis 5 & \multicolumn{2}{|c|}{ Mean $2 \pm \sigma$} \\
\hline 2.821 & 1.42 & 1.54 & 1.42 & 1.42 & 1.14 & \multicolumn{2}{|c|}{$1.39 \pm 0.30$} \\
\hline 1.994 & 1.17 & 1.12 & 1.27 & 1.22 & 1.27 & \multicolumn{2}{|c|}{$1.22 \pm 0.15$} \\
\hline
\end{tabular}

${ }^{\mathrm{a}}$ Detection limits calculated for 0.1 area $\%$.

${ }^{\mathrm{b}}$ Peak not resolved. 
Table 39. Results of replicate PCTs with EA glass and salt-loaded CWF materials

\begin{tabular}{|c|c|c|c|c|c|}
\hline & $\mathrm{pH}$ & $N C(\mathrm{~B}), \mathrm{g} / \mathrm{L}$ & $N C(\mathrm{Li}), \mathrm{g} / \mathrm{L}$ & $N C(\mathrm{Na}), \mathrm{mg} / \mathrm{L}$ & $N C(\mathrm{Si}), \mathrm{g} / \mathrm{L}$ \\
\hline \multicolumn{6}{|c|}{ EA glass } \\
\hline $\mathrm{SRNL}^{\mathrm{a}}$ & 11.85 & $16.9 \pm 1.2$ & $9.69 \pm 0.71$ & $13.3 \pm 0.9$ & $3.92 \pm 0.38$ \\
\hline $\mathrm{PNNL}^{\mathrm{b}}$ & 11.92 & $15.7 \pm 0.9$ & $7.39 \pm 0.61$ & $12.3 \pm 0.5$ & $2.78 \pm 0.25$ \\
\hline $\mathrm{ANL}^{\mathrm{C}}$ & 11.83 & $15.2 \pm 3.9$ & $9.54 \pm 2.50$ & $12.2 \pm 2.8$ & $3.89 \pm 0.70$ \\
\hline \multicolumn{6}{|c|}{ Salt-loaded CWF } \\
\hline$S 1 A^{d}$ & 8.61 & $0.685 \pm 0.056$ & Not analyzed & $0.287 \pm 0.003$ & $0.212 \pm 0.003$ \\
\hline$S 2 B^{d}$ & 8.49 & $0.184 \pm 0.020$ & Not analyzed & $0.233 \pm 0.007$ & $0.199 \pm 0.002$ \\
\hline S3A $A^{d}$ & 8.45 & $0.133 \pm 0.010$ & Not analyzed & $0.248 \pm 0.005$ & $0.178 \pm 0.006$ \\
\hline S3C ${ }^{d}$ & 8.48 & $0.131 \pm 0.004$ & Not analyzed & $0.259 \pm 0.005$ & $0.175 \pm 0.004$ \\
\hline S3E ${ }^{d}$ & 8.41 & $0.146 \pm 0.002$ & Not analyzed & $0.312 \pm 0.011$ & $0.172 \pm 0.001$ \\
\hline$S 4 A^{d}$ & 8.33 & $0.124 \pm 0.004$ & Not analyzed & $0.312 \pm 0.021$ & $0.124 \pm 0.006$ \\
\hline $\mathrm{S} \mathrm{B}^{\mathrm{d}}$ & 8.43 & $0.168 \pm 0.015$ & Not analyzed & $0.378 \pm 0.017$ & $0.124 \pm 0.005$ \\
\hline $\mathrm{G}_{1 A^{\mathrm{d}}}$ & 8.40 & $0.158 \pm 0.003$ & Not analyzed & $0.383 \pm 0.001$ & $0.117 \pm 0.002$ \\
\hline $\mathrm{G}^{2} \mathrm{~A}^{\mathrm{d}}$ & 8.35 & $0.162 \pm 0.003$ & Not analyzed & $0.341 \pm 0.017$ & $0.124 \pm 0.002$ \\
\hline $\mathrm{G}_{4} \mathrm{~A}^{\mathrm{d}}$ & 8.40 & $0.121 \pm 0.002$ & Not analyzed & $0.267 \pm 0.060$ & $0.142 \pm 0.002$ \\
\hline $\mathrm{G} \mathrm{A}^{\mathrm{d}}$ & 8.42 & $0.138 \pm 0.001$ & Not analyzed & $0.288 \pm 0.008$ & $0.155 \pm 0.003$ \\
\hline \multicolumn{6}{|c|}{ Heat-treated CWF } \\
\hline No heat $^{d}$ & 8.72 & $0.112 \pm 0.004$ & Not analyzed & $0.221 \pm 0.012$ & $0.160 \pm 0.006$ \\
\hline $600^{e}$ & 8.71 & $0.106 \pm 0.006$ & Not analyzed & $0.192 \pm 0.032$ & $0.138 \pm 0.010$ \\
\hline $700^{e}$ & 8.76 & $0.110 \pm 0.005$ & Not analyzed & $0.250 \pm 0.004$ & $0.161 \pm 0.004$ \\
\hline $800^{\mathrm{e}}$ & 8.74 & $0.098 \pm 0.002$ & Not analyzed & $0.207 \pm 0.011$ & $0.145 \pm 0.003$ \\
\hline $850^{\mathrm{e}}$ & 8.75 & $0.101 \pm 0.005$ & Not analyzed & $0.243 \pm 0.005$ & $0.159 \pm 0.016$ \\
\hline
\end{tabular}

${ }^{\mathrm{a}}$ Andrews and Bibler 1993 (mean and standard deviation of 42 replicate tests).

${ }^{\mathrm{b}}$ Olson et al. 1995 (mean and standard deviation of 14 replicate tests).

${ }^{\mathrm{c}}$ Ebert et al. 1998 (mean and standard deviation of 9 replicate tests).

${ }^{\mathrm{d}}$ Mean and standard deviation of triplicate tests.

${ }^{\mathrm{e}}$ Mean and standard deviation of materials heated for 28, 52, and 100 hours. 
Table 40. Glass compositions on an oxide basis, as total mass $\%$

\begin{tabular}{|c|c|c|c|c|c|c|c|c|c|c|c|}
\hline S1A & S2C & S3A & S3C & S3E & S4A & S4A dup. & S5B & G1A & G2A & G3A & G4A \\
\hline 99.0 & 99.1 & 97.1 & 98.2 & 91.6 & 100 & 97.5 & 98.7 & 101 & 100 & 103 & 97.5 \\
\hline
\end{tabular}




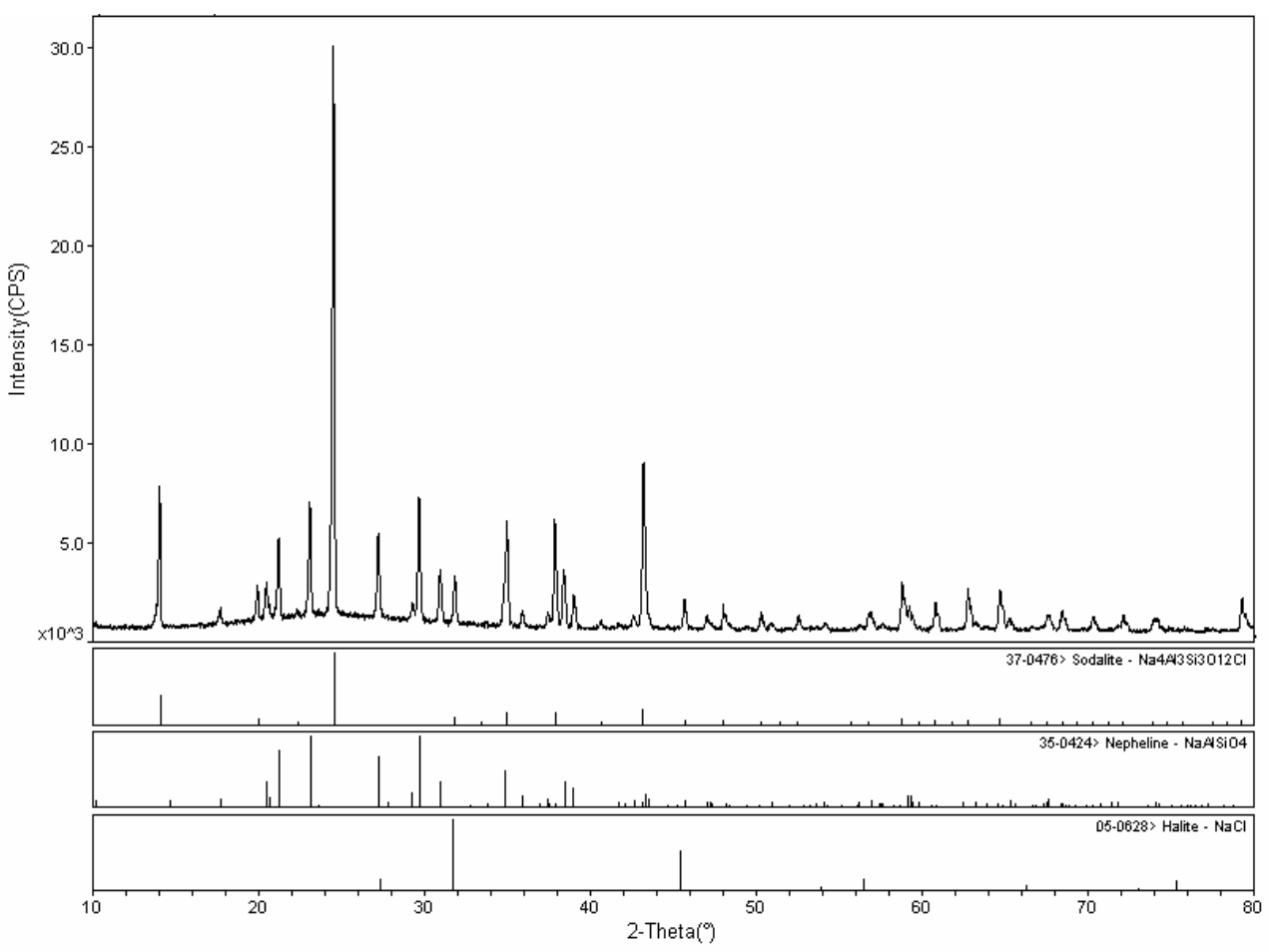

(a) S1A

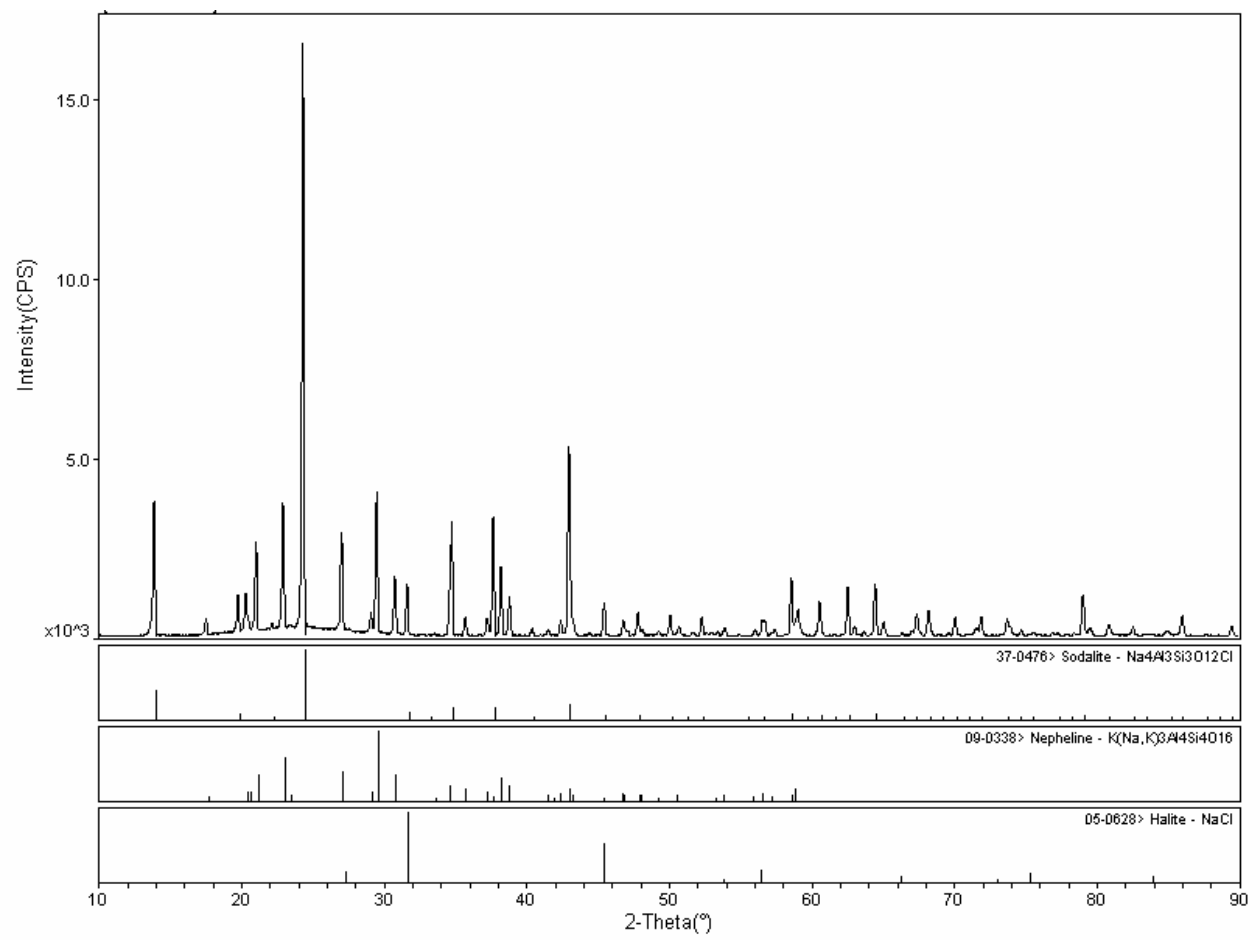

(b) S1B

Fig. 1. XRD spectra of salt-loaded CWF products: (a) S1A, (b) S1B, (c) S2C, (d) S3A, (e) S3B, (f) S3C, (g) S3E, (h) S4A, (i) S5B, (j) G1A, (k) G2A, (1) G4A, and (m) G5A. 


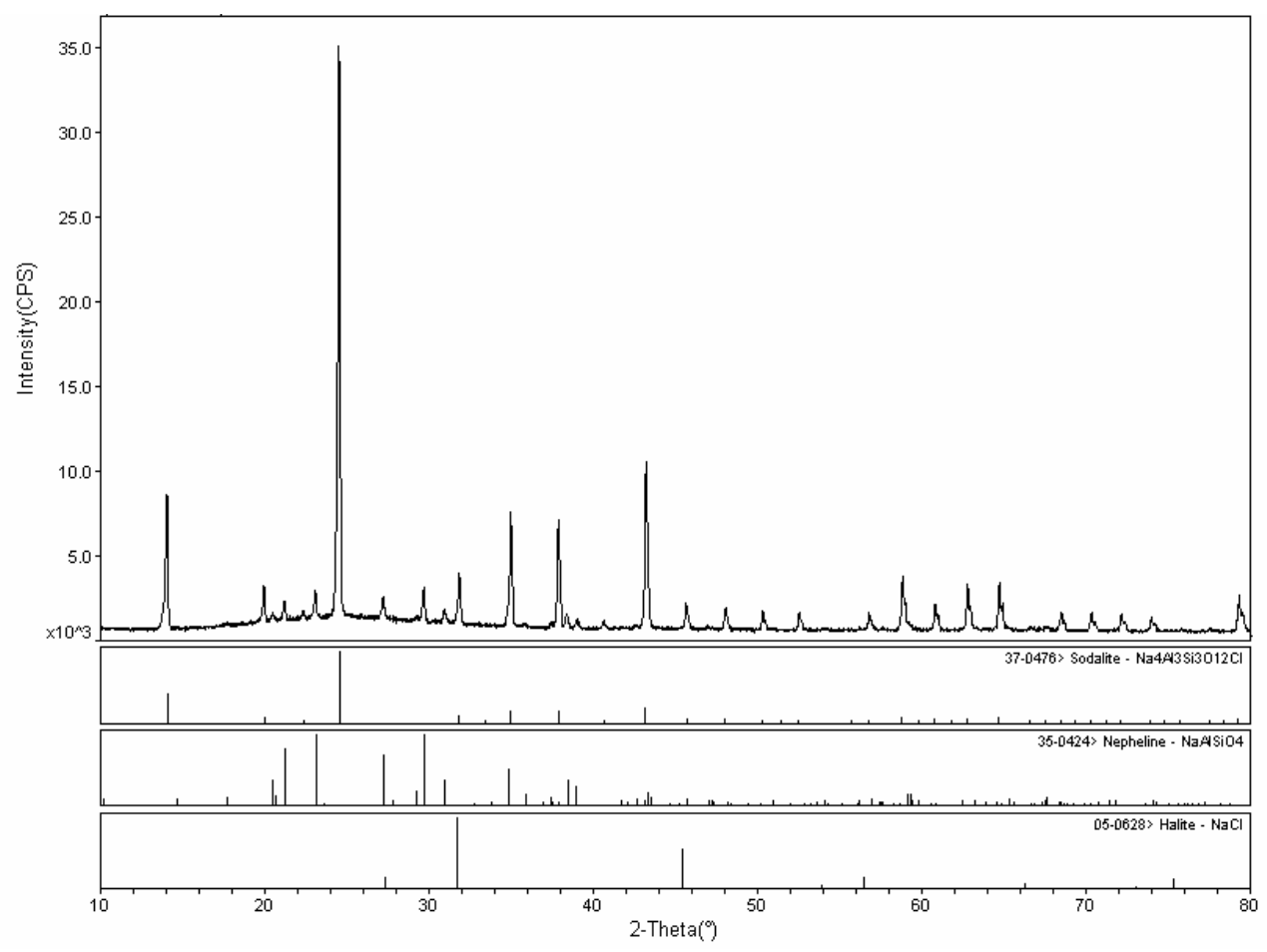

(c) $\mathrm{S} 2 \mathrm{C}$

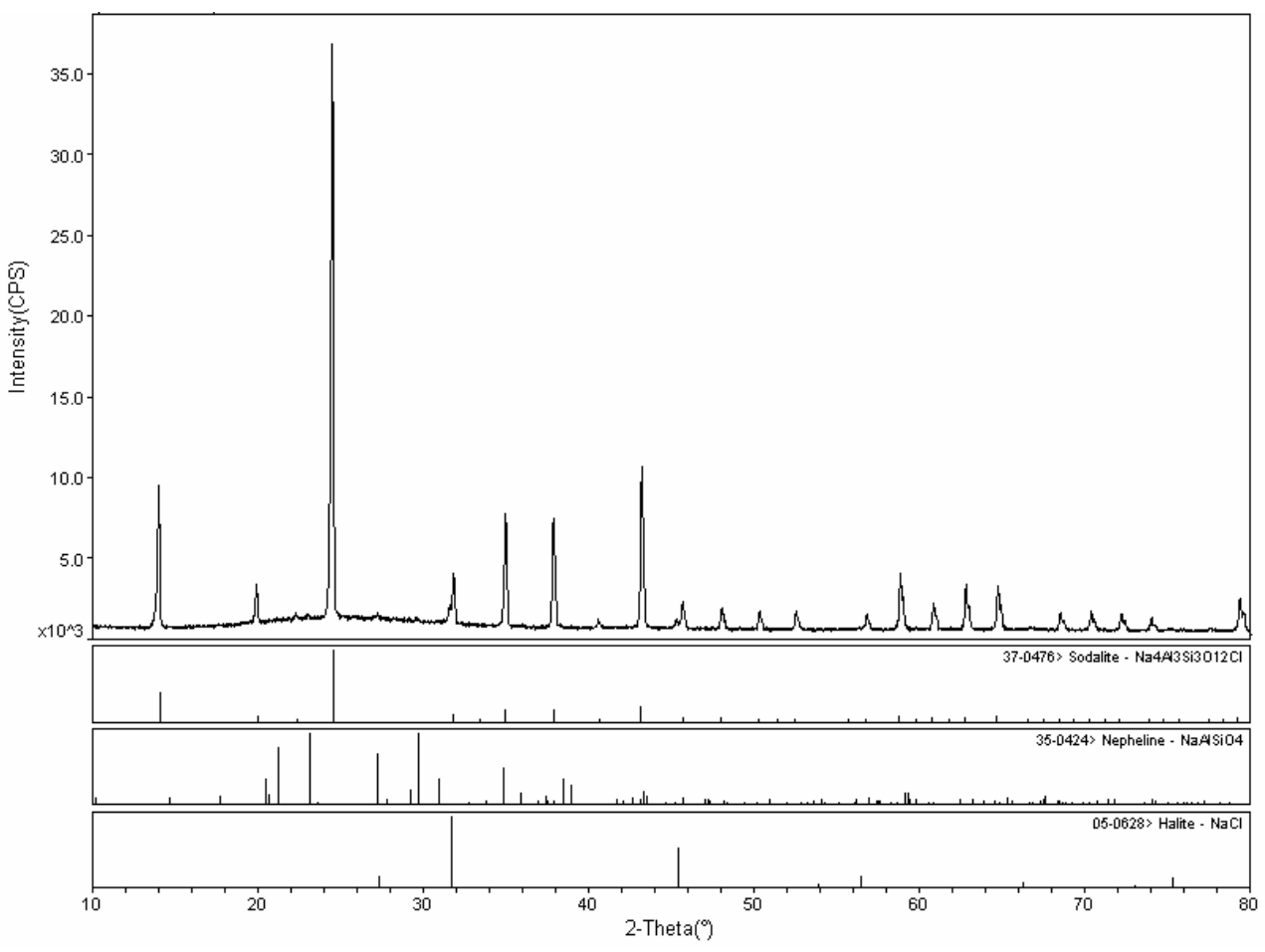

(d) $\mathrm{S} 3 \mathrm{~A}$

Fig. 1 (continued) 


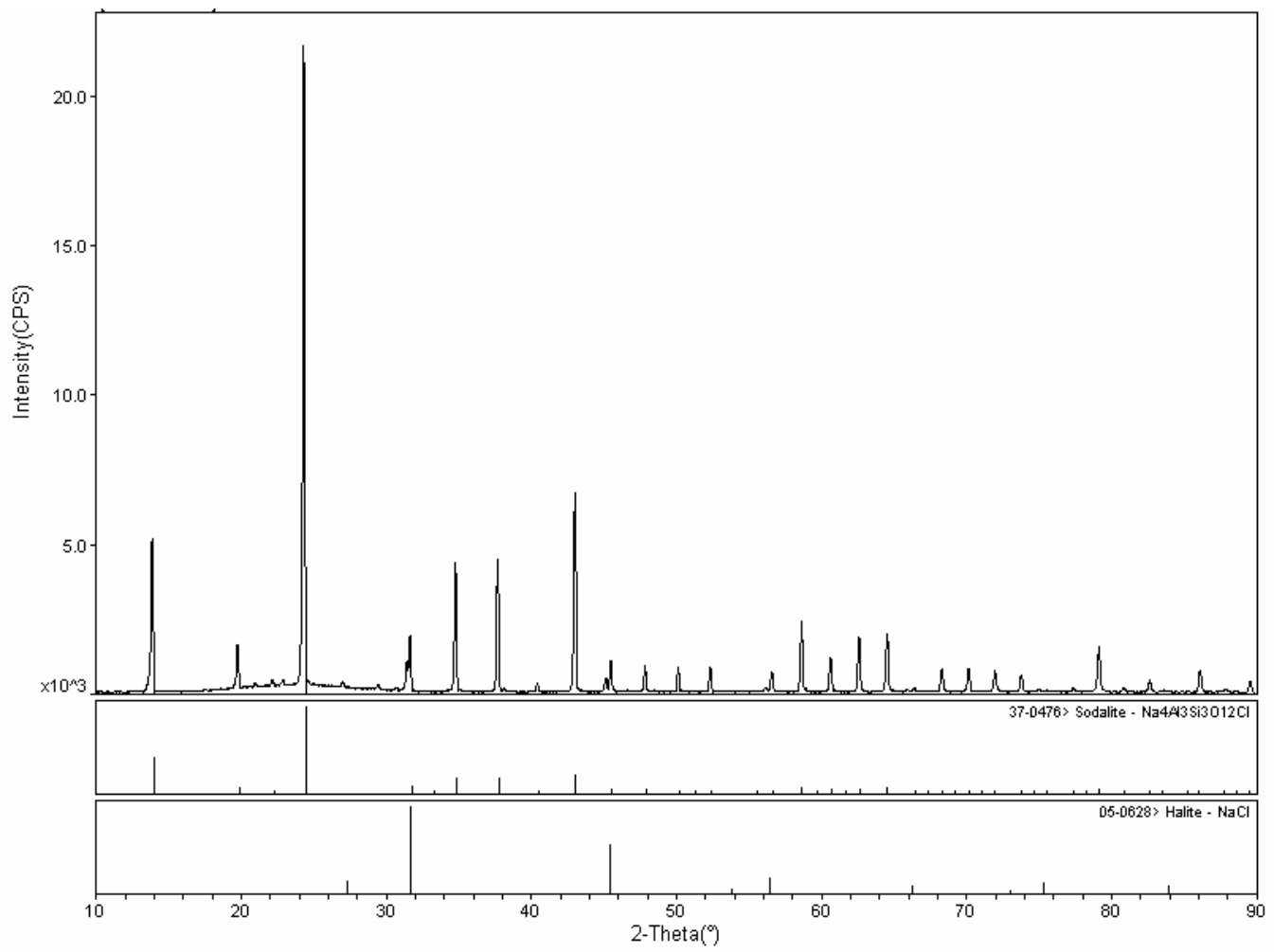

(e) $\mathrm{S} 3 \mathrm{~B}$

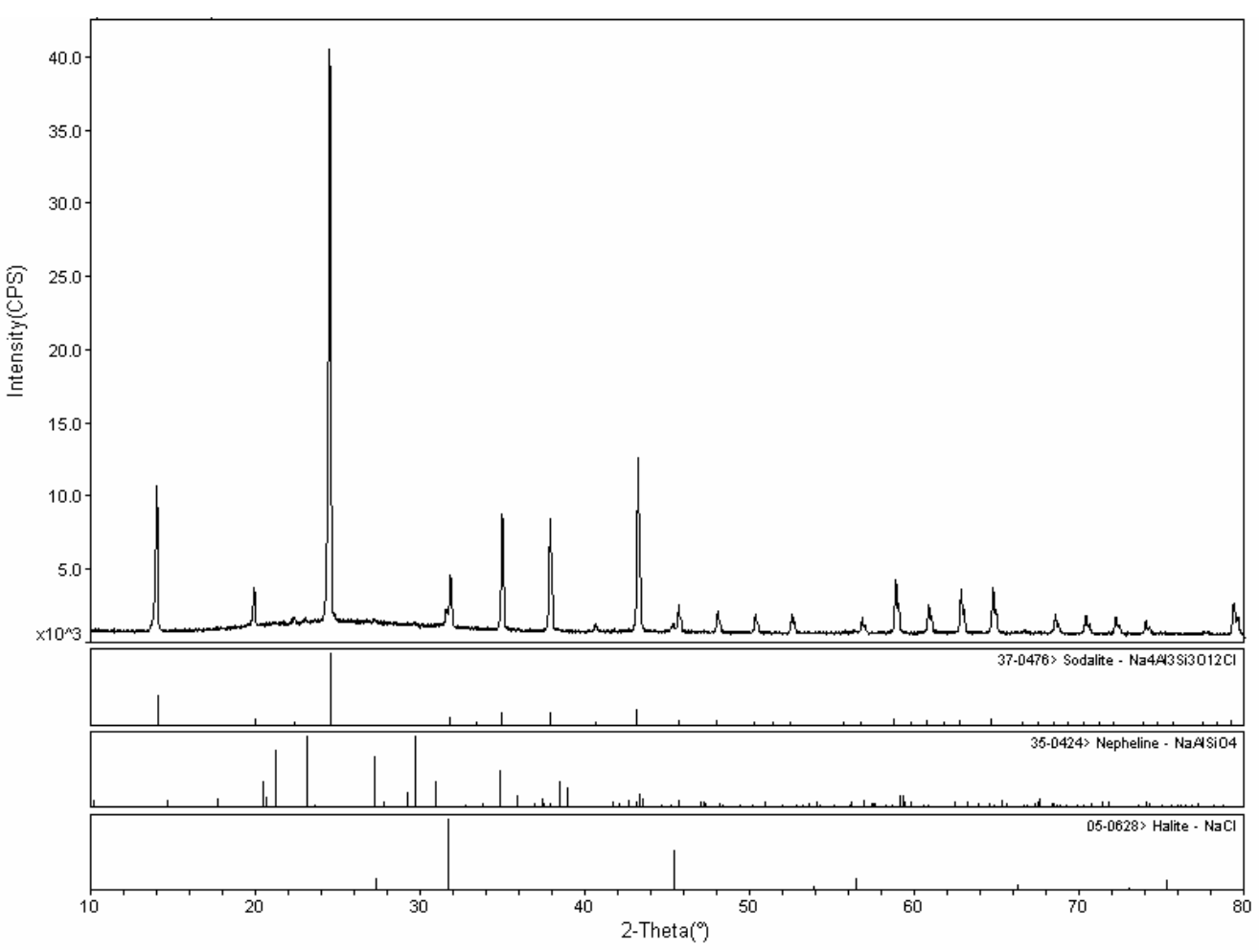

(f) $\mathrm{S} 3 \mathrm{C}$

Fig. 1. (continued) 


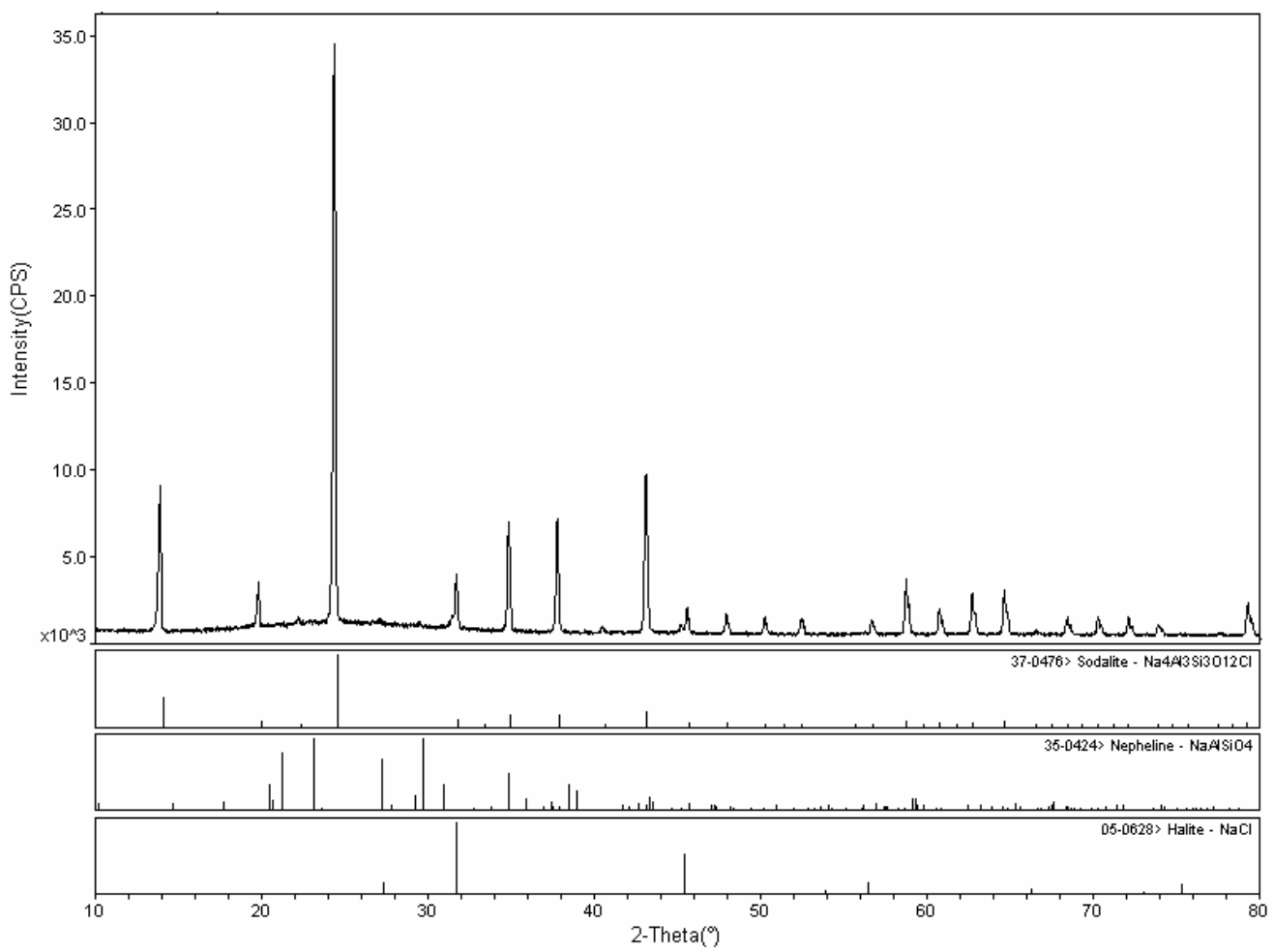

(g) $\mathrm{S} 3 \mathrm{E}$

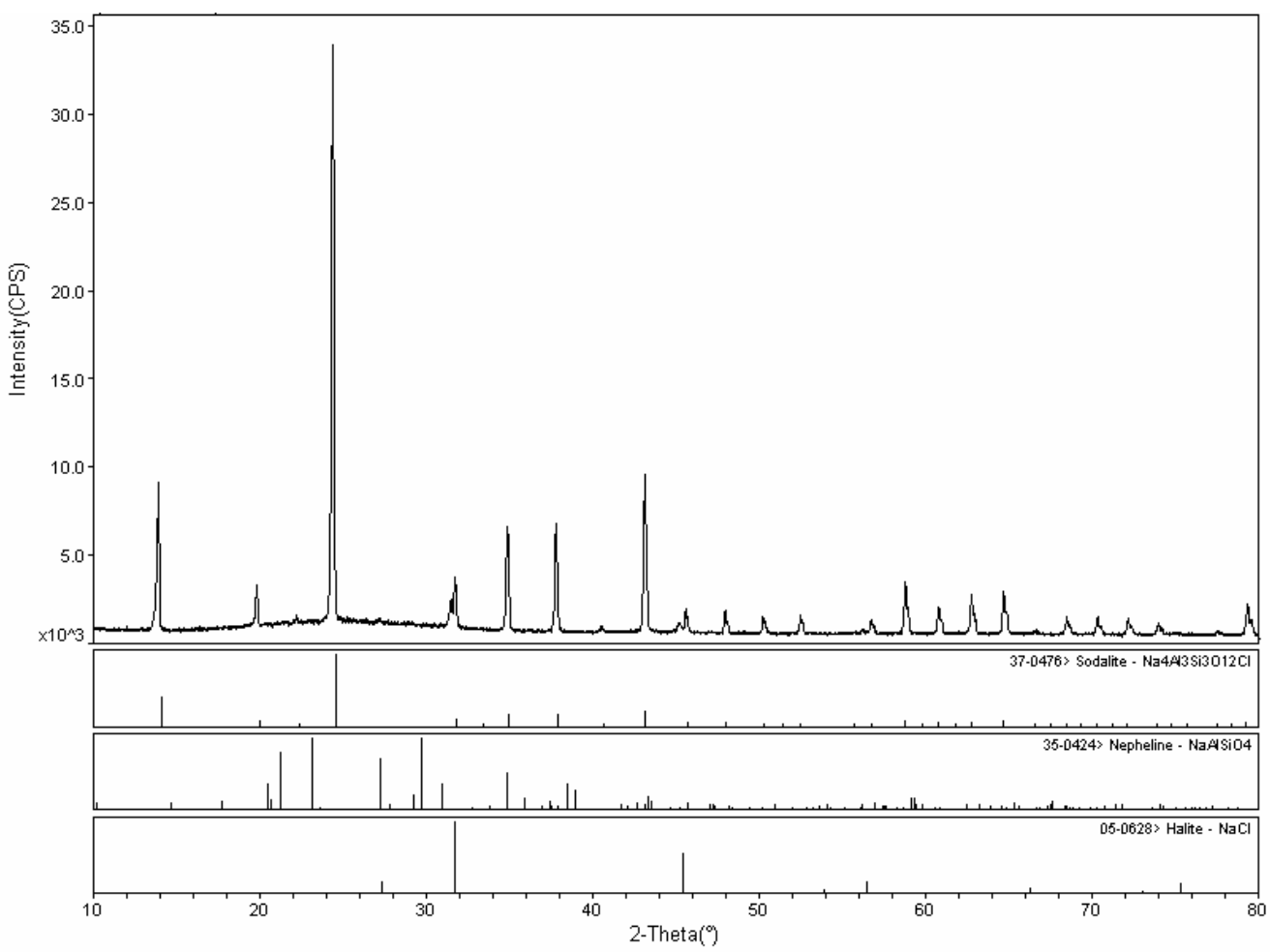

(h) $\mathrm{S} 4 \mathrm{~A}$

Fig. 1. (continued) 


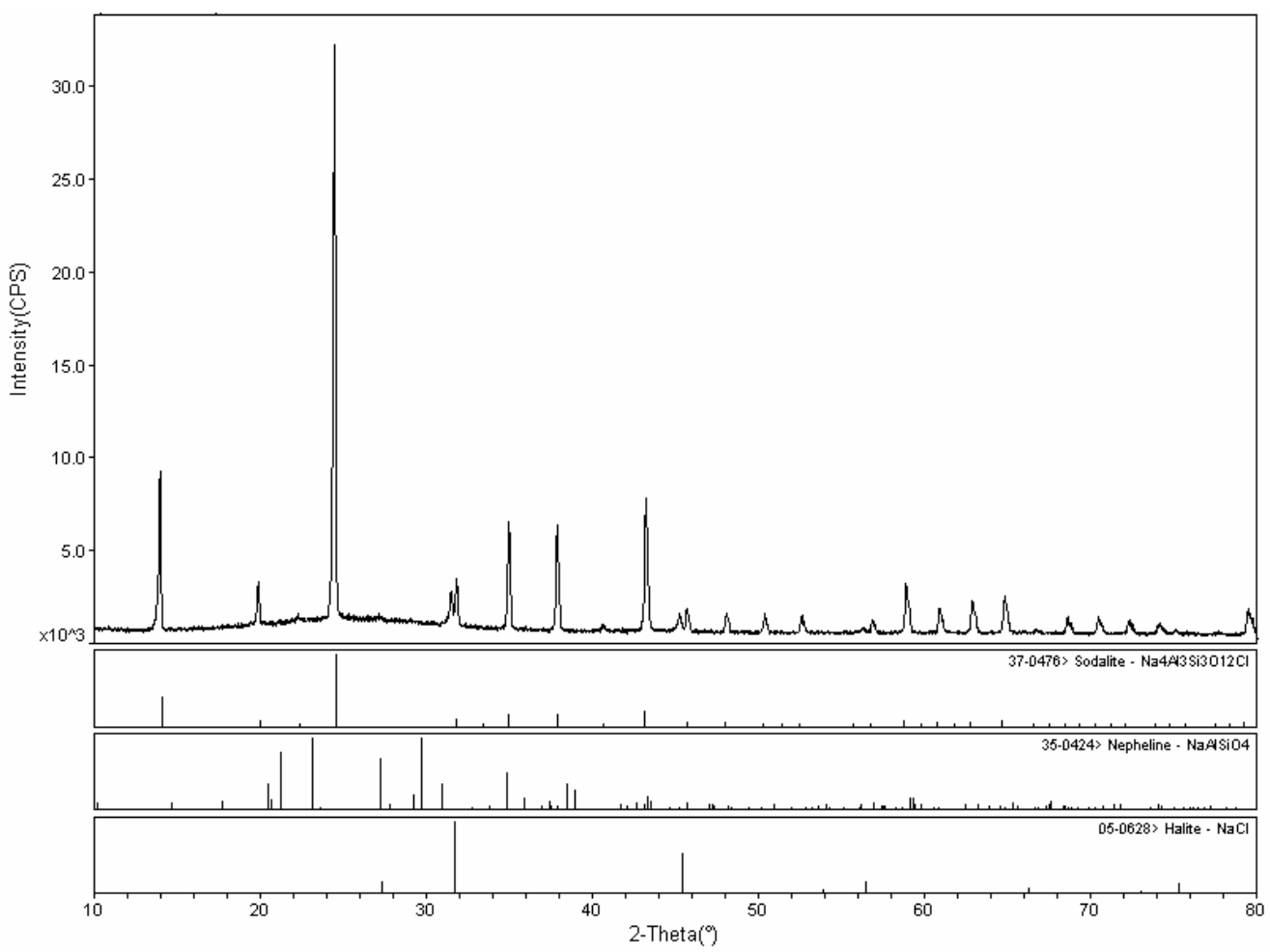

(i) $\mathrm{S} 5 \mathrm{~B}$

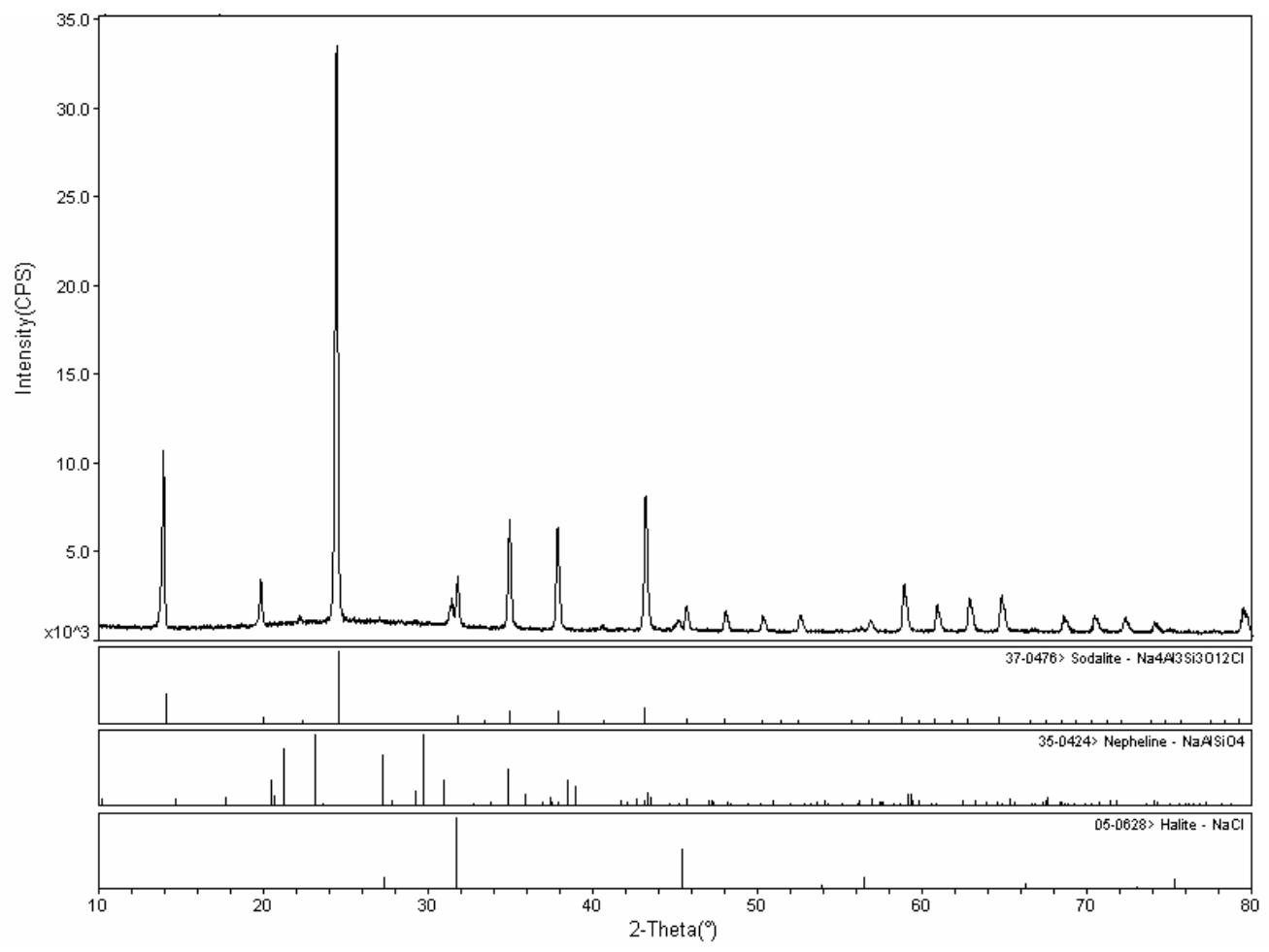

(j) G1A

Fig. 1. (continued) 


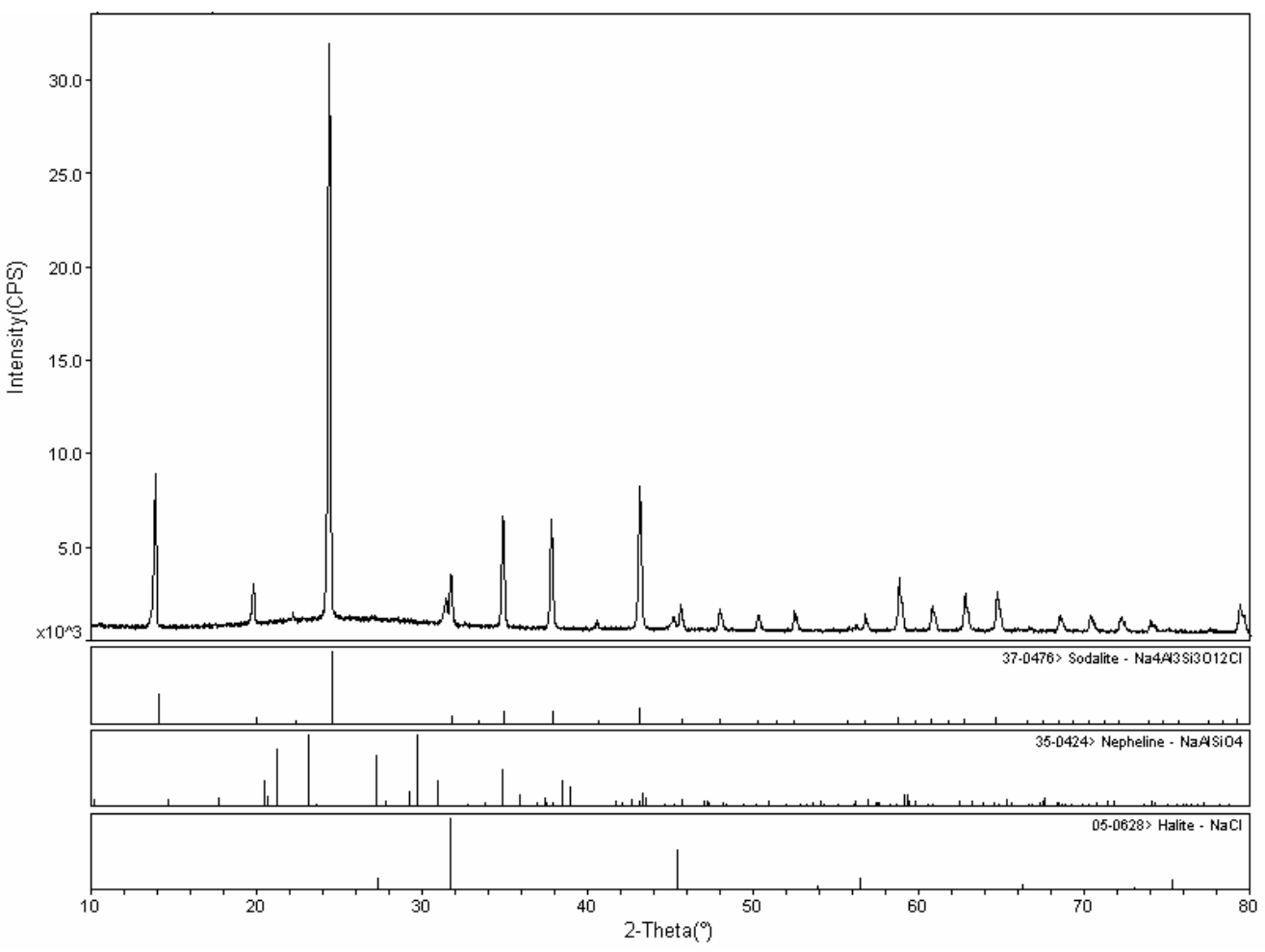

(k) G2A

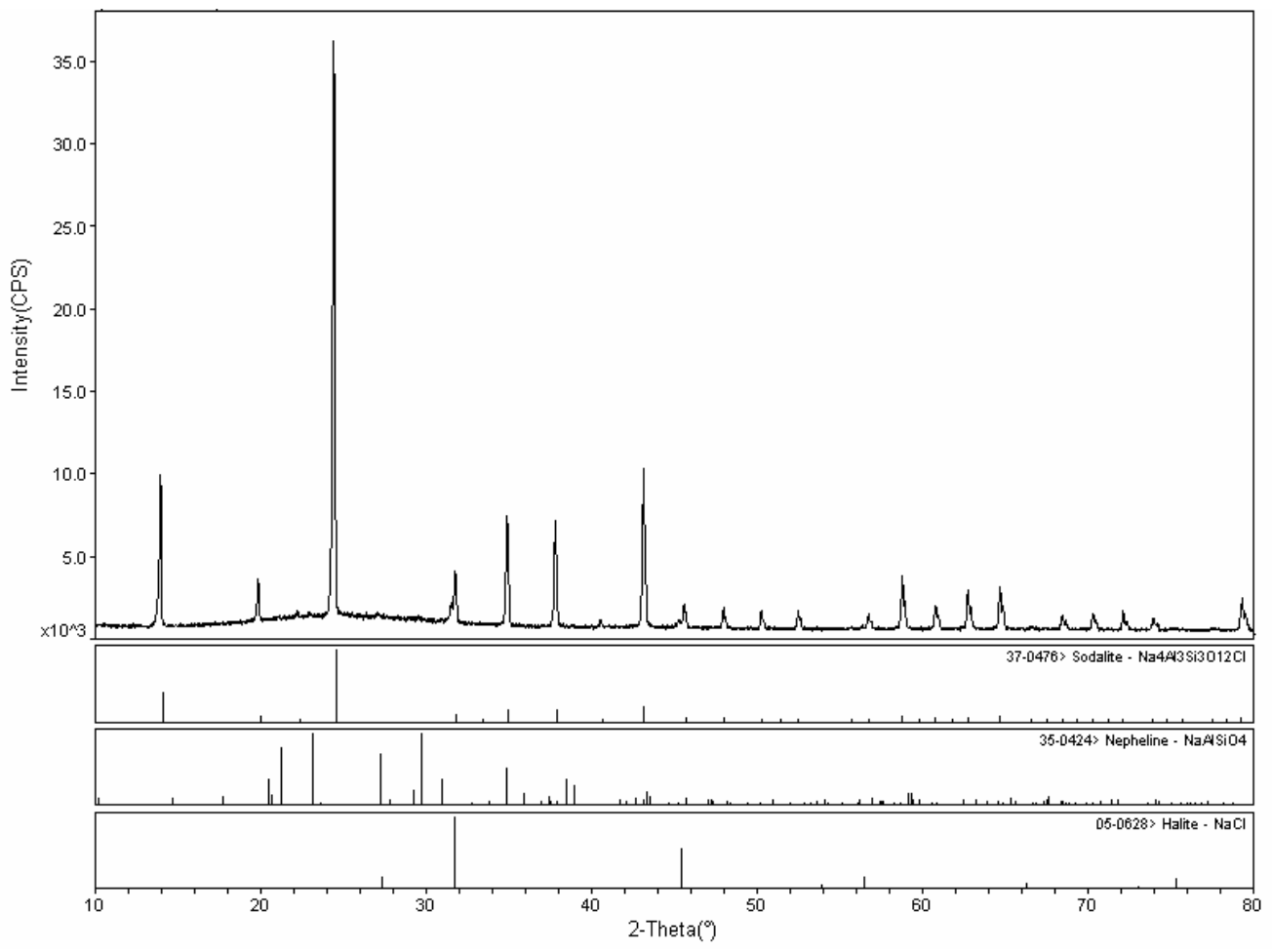

(1) $\mathrm{G} 4 \mathrm{~A}$

Fig. 1. (continued) 


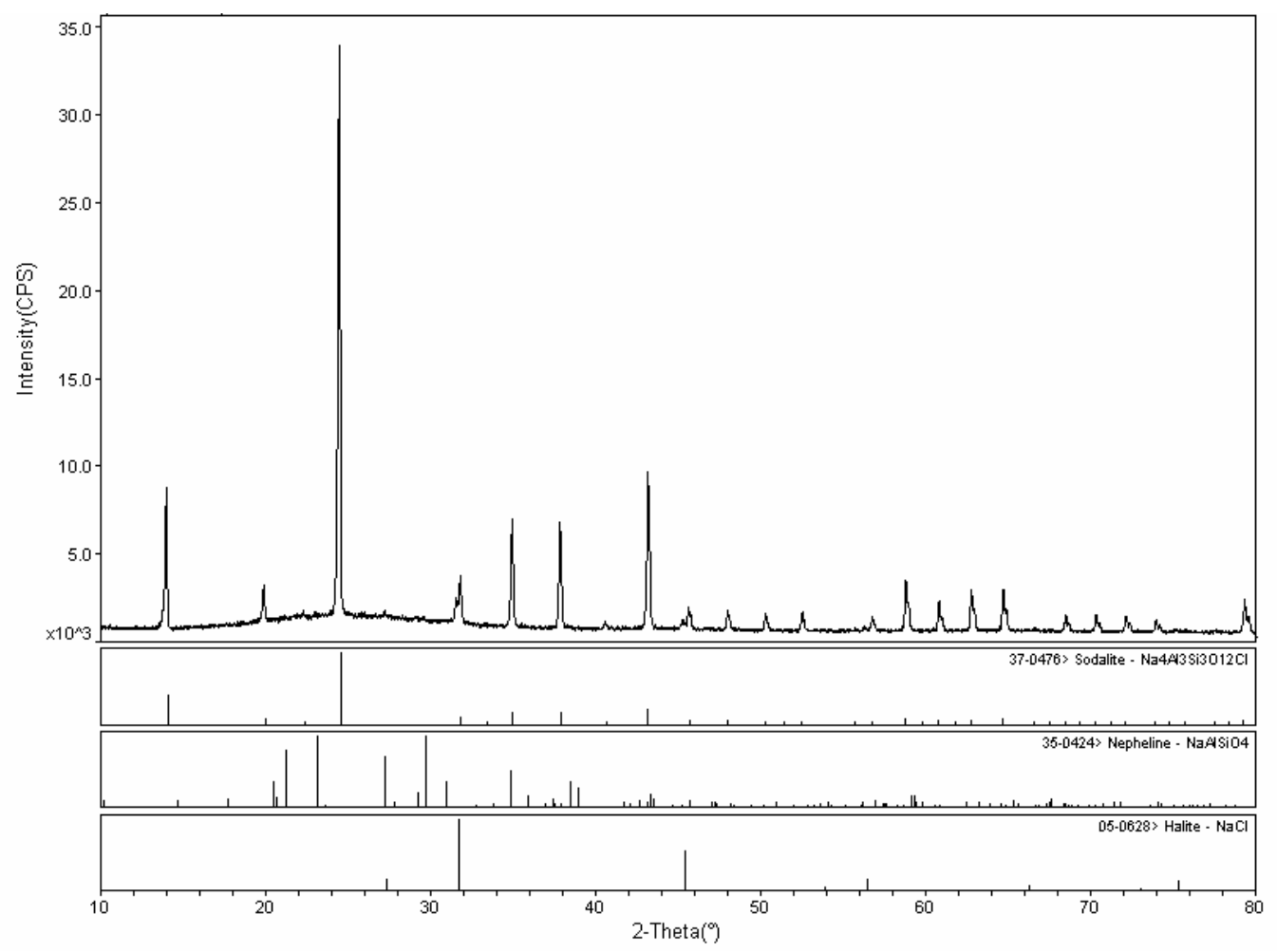

(m) $\mathrm{G} 5 \mathrm{~A}$

Fig. 1. (continued) 


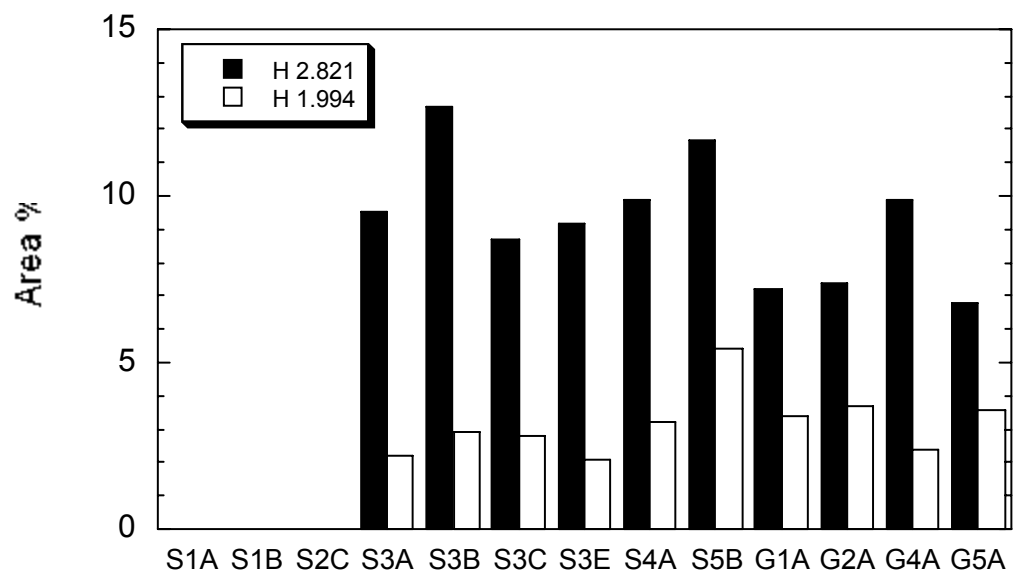

(a)

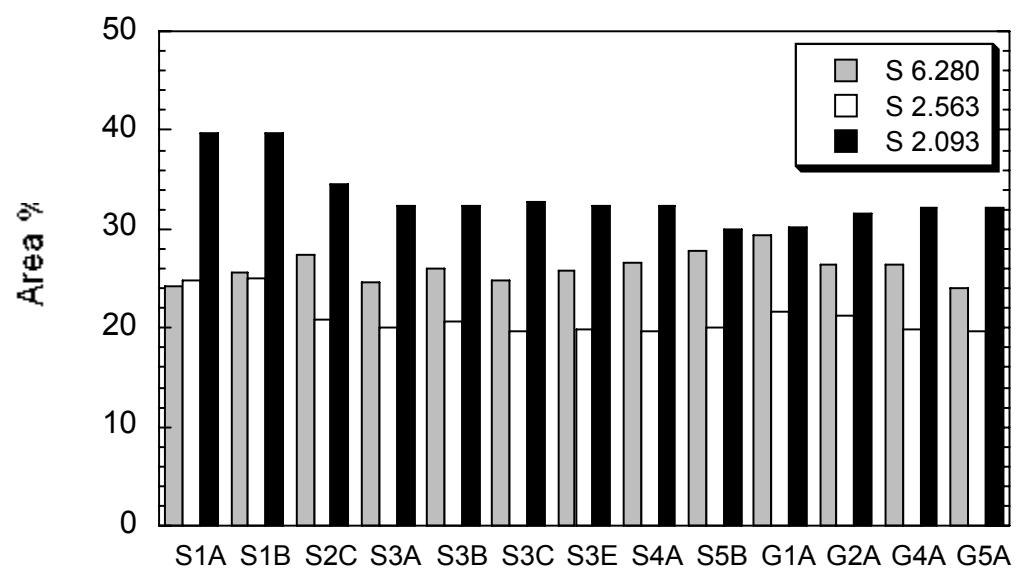

(b)

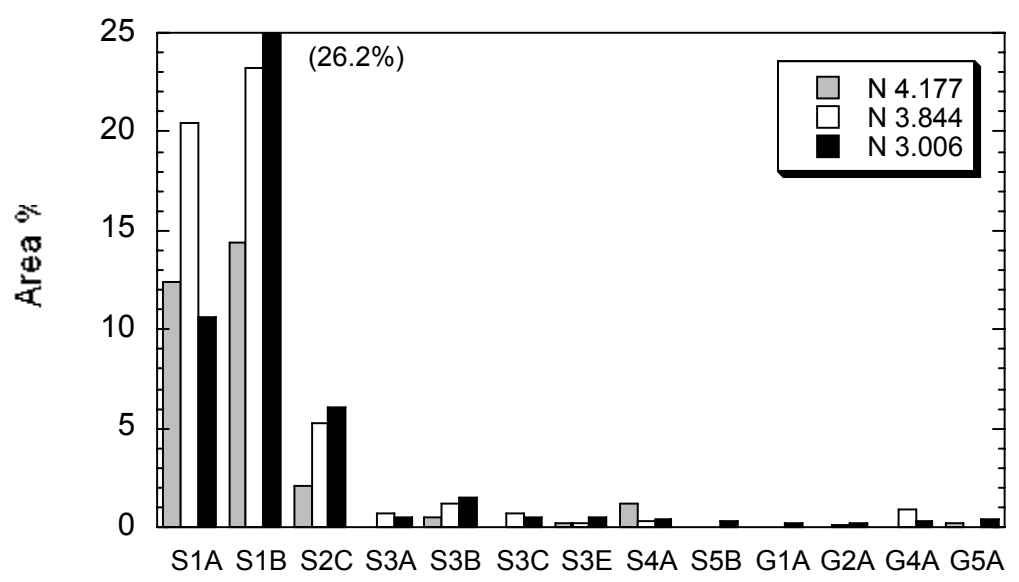

(c)

Fig. 2. Relative amounts of (a) halite, (b) sodalite, and (c) nepheline formed in salt-loaded CWF products. Amounts were determined as area $\%$ of several XRD peaks. 


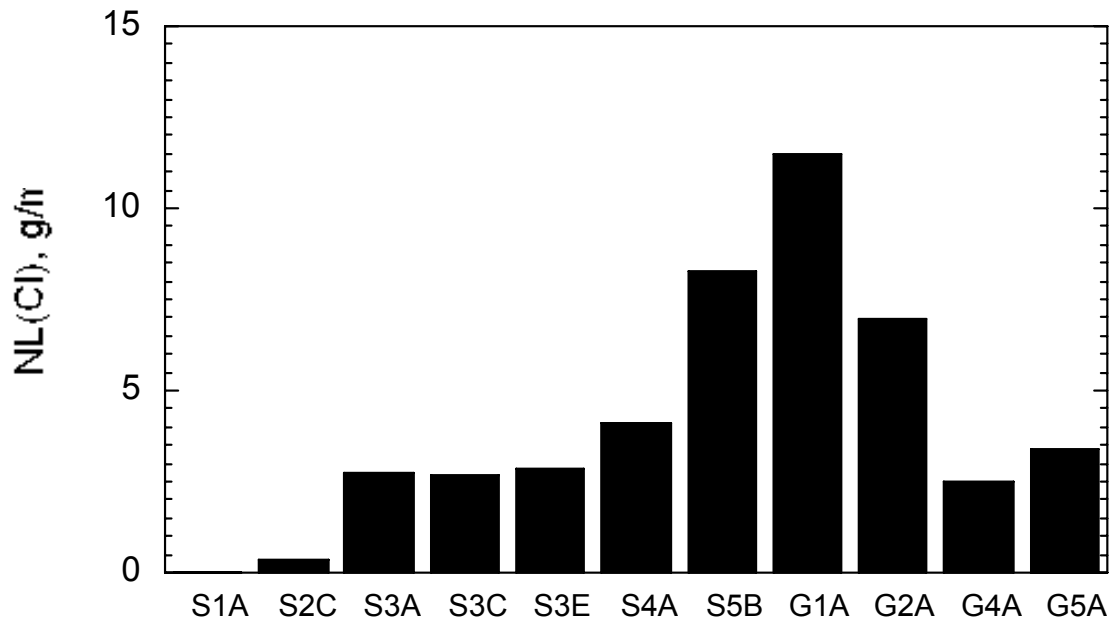

Fig. 3. Chloride release in RWS tests with salt-loaded CWF products.

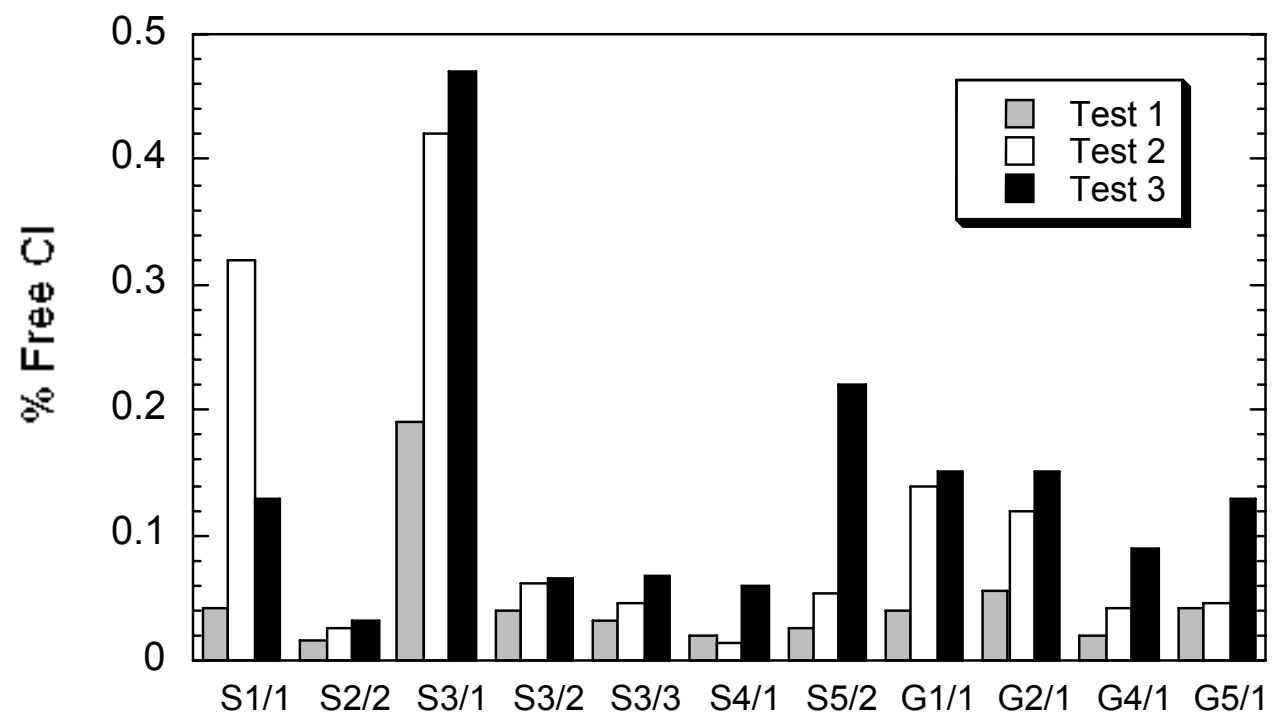

Fig. 4. Free chloride measured for batches of SLZs used to make salt-loaded CWF products. 


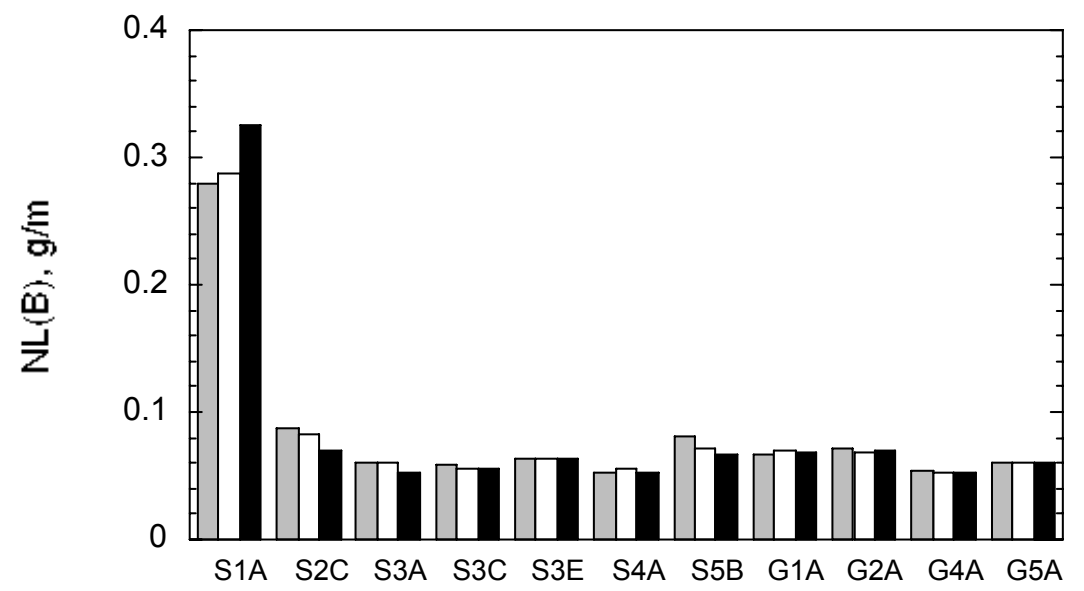

(a)

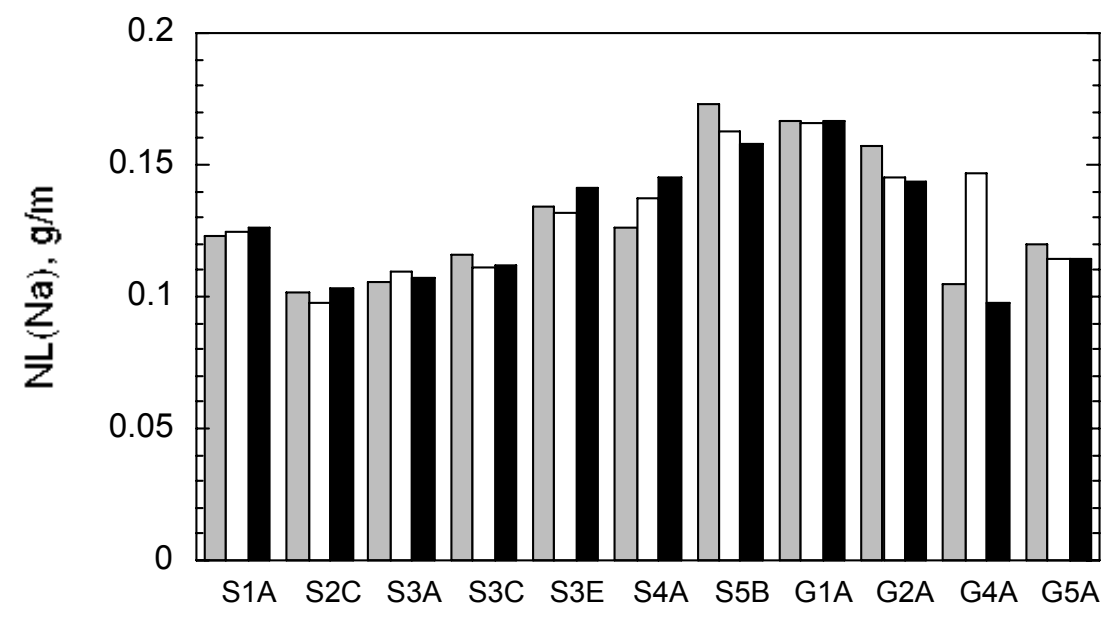

(b)

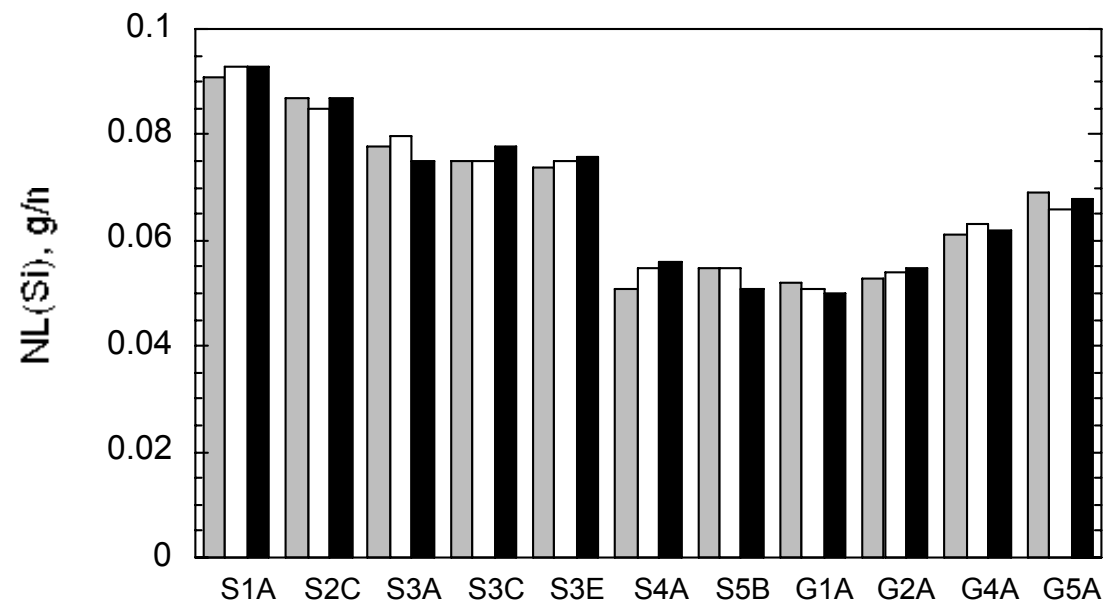

(c)

Fig. 5. Normalized elemental mass losses in 7-day PCT with salt-loaded CWF products: (a) $N L(\mathrm{~B})(\mathrm{b}) N L(\mathrm{Na})$, and (c) $N L(\mathrm{Si})$ for different salt loadings. 


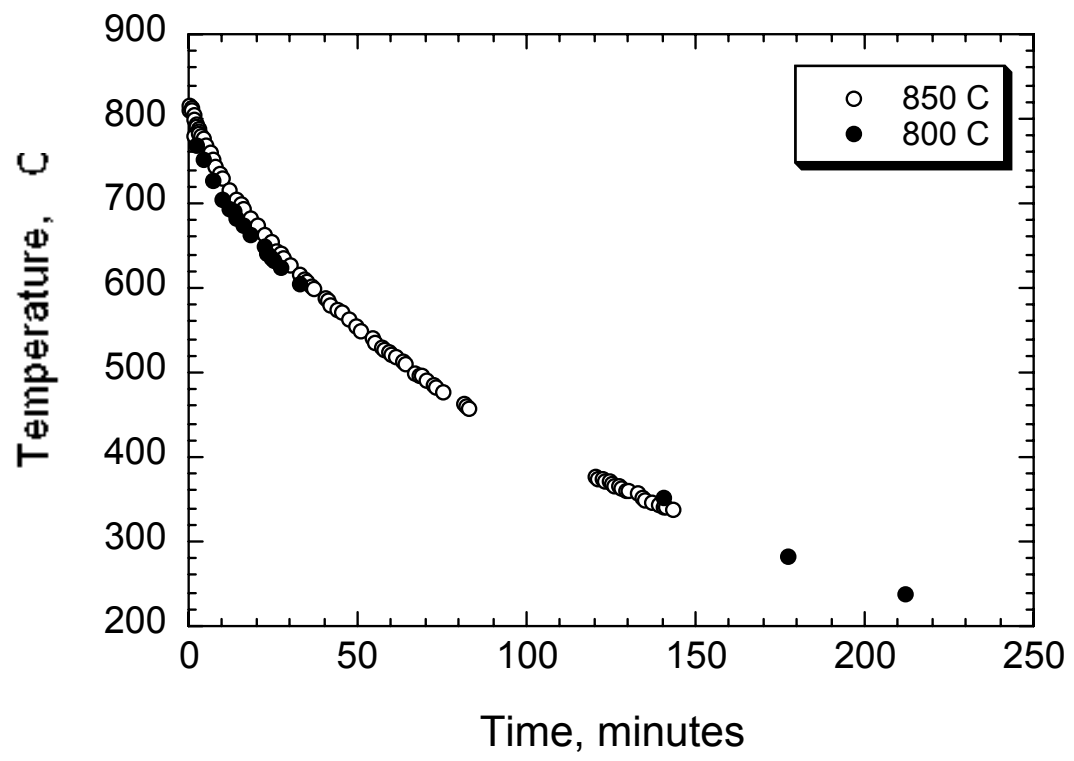

Fig. 6. Oven cooling curves after heat treatments at 800 and $850{ }^{\circ} \mathrm{C}$. 


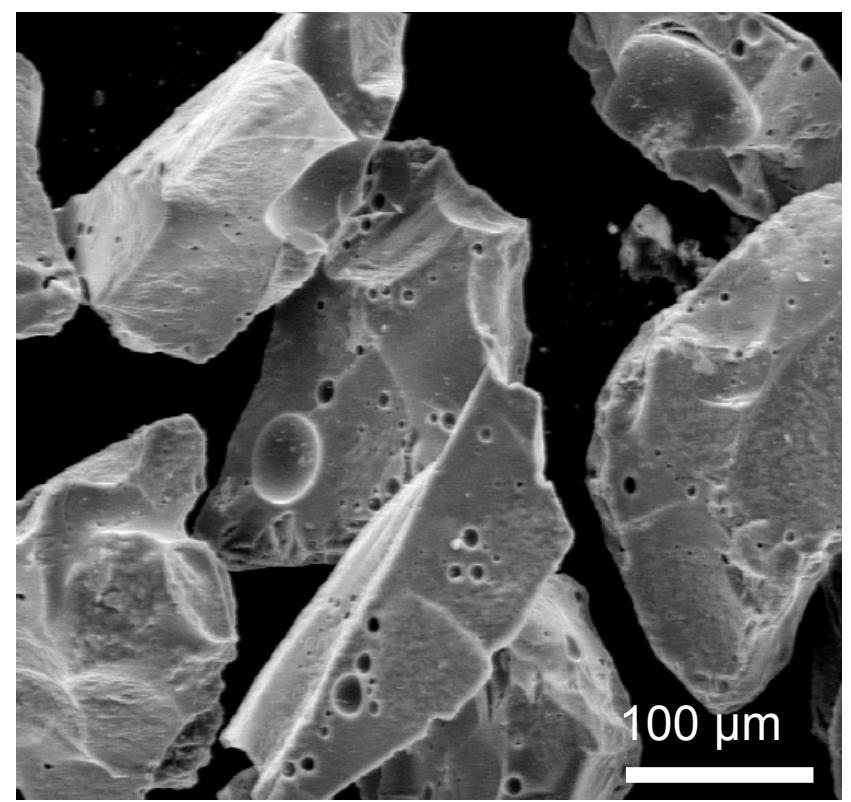

(a)

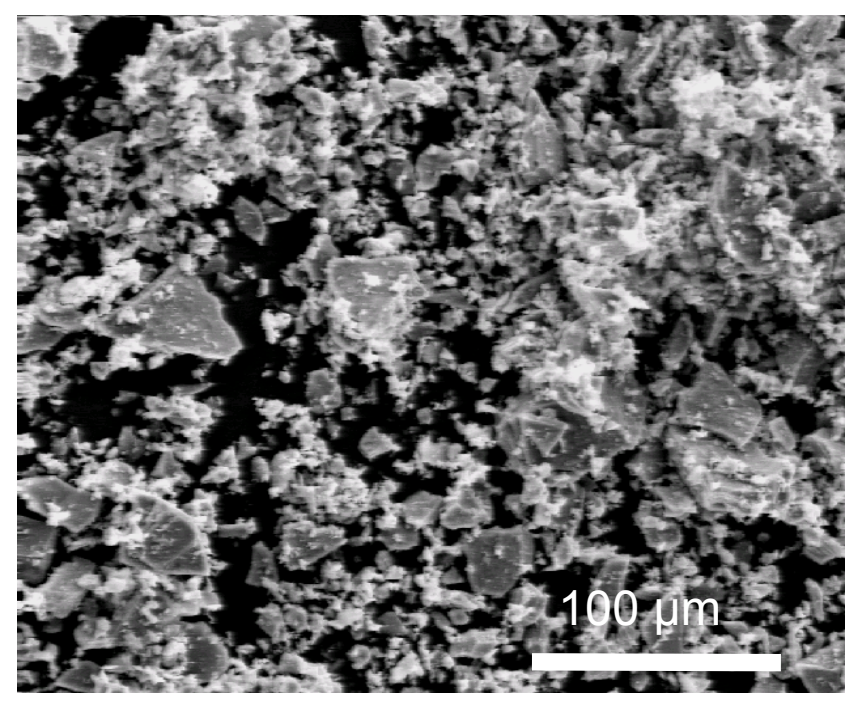

(c)

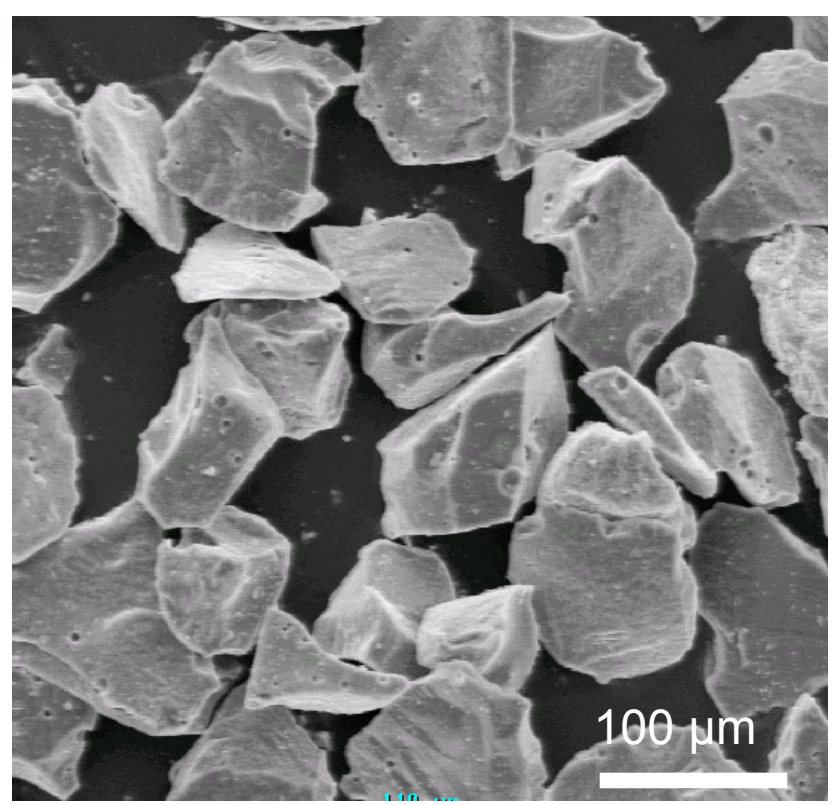

(b)

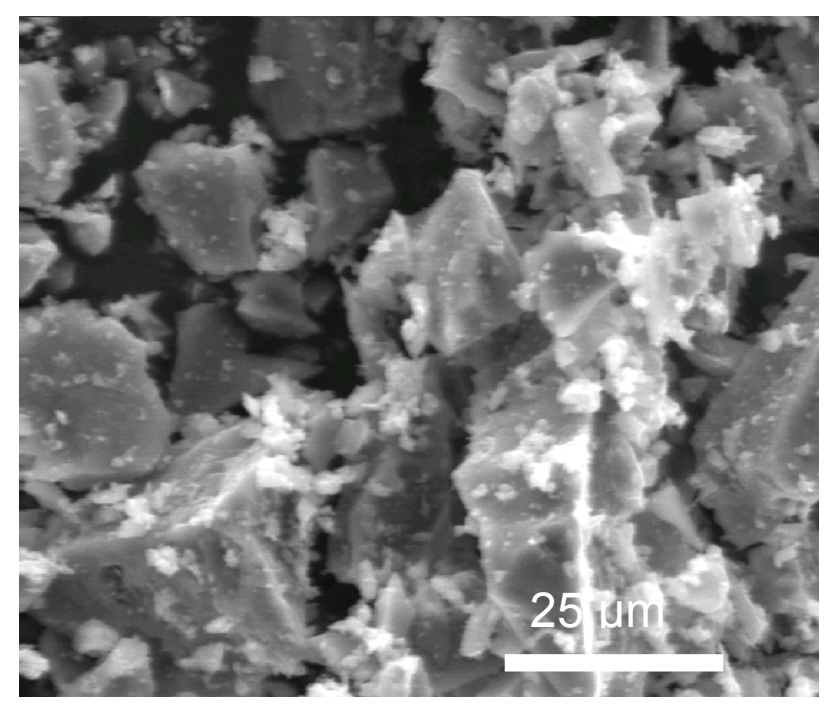

(d)

Fig. 7. Crushed heat-treated CWF samples: (a) $-100+200$ mesh size fraction, (b) $-200+325$ mesh size fraction, and pulverized material at (c) low magnification and (d) high magnification. The large particles are glass, and most of the small particles are sodalite and halite. 


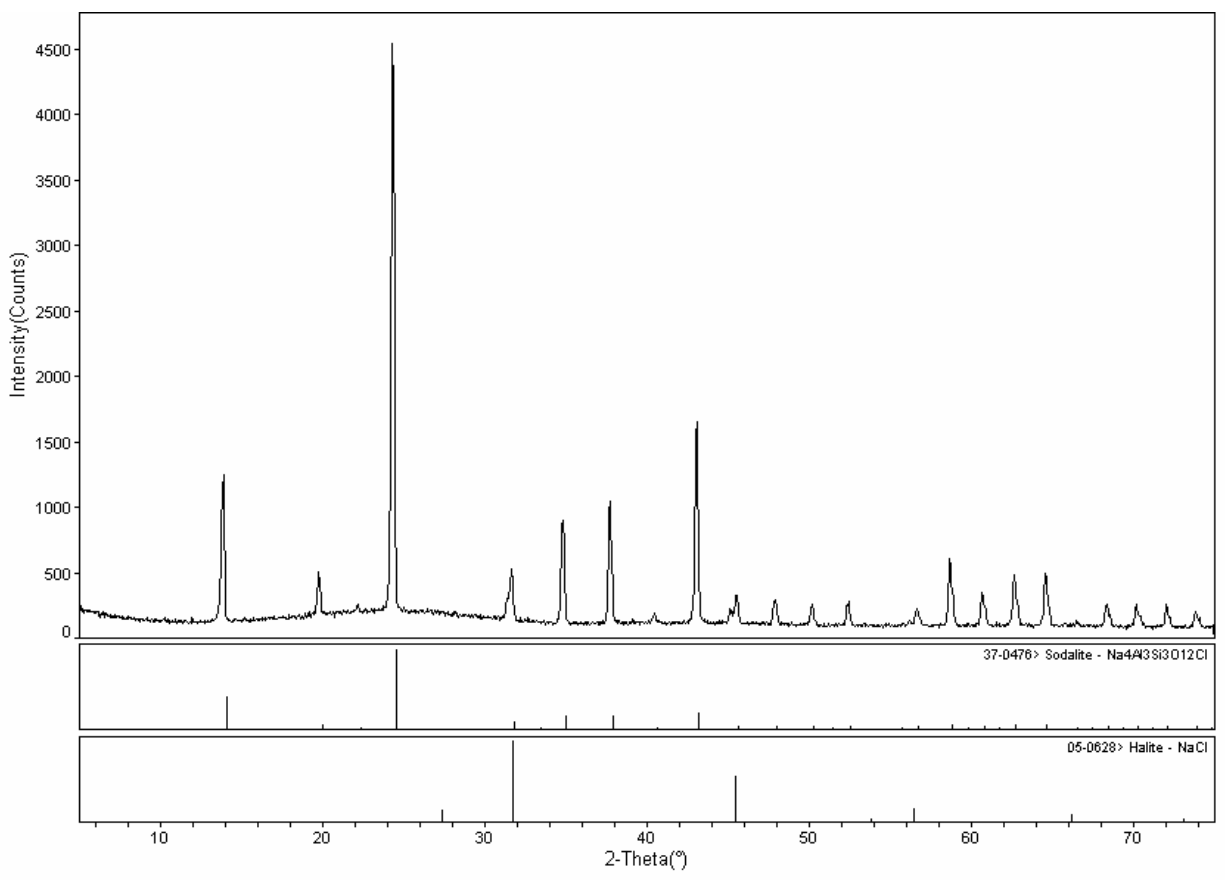

(a)

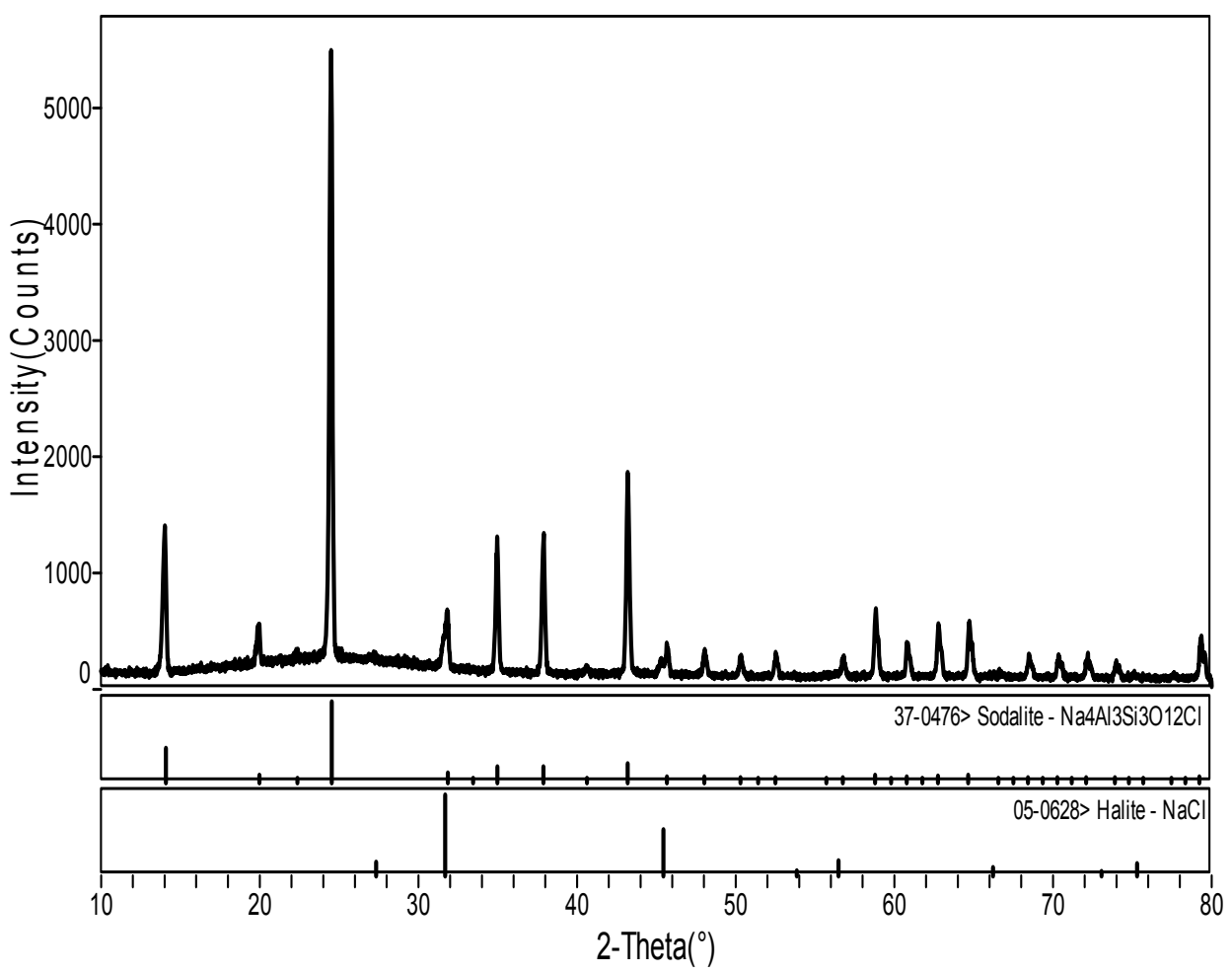

(b)

Fig. 8. XRD spectra of long-term heat-treated CWF samples heated at $400{ }^{\circ} \mathrm{C}$ : (a) 1 week, (b) 4 weeks, (c) 3 months, (d) 6 months, and (e) 1 year. 


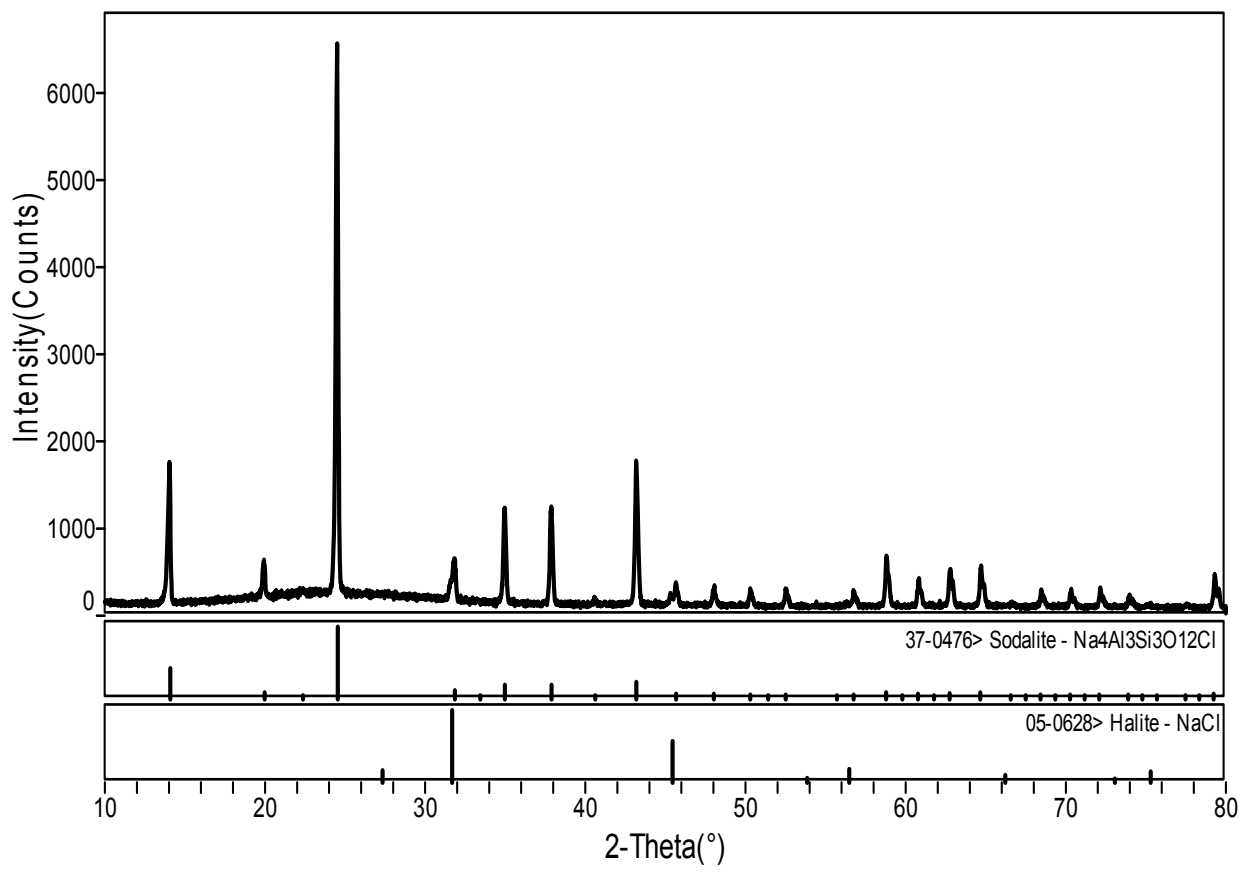

(c)

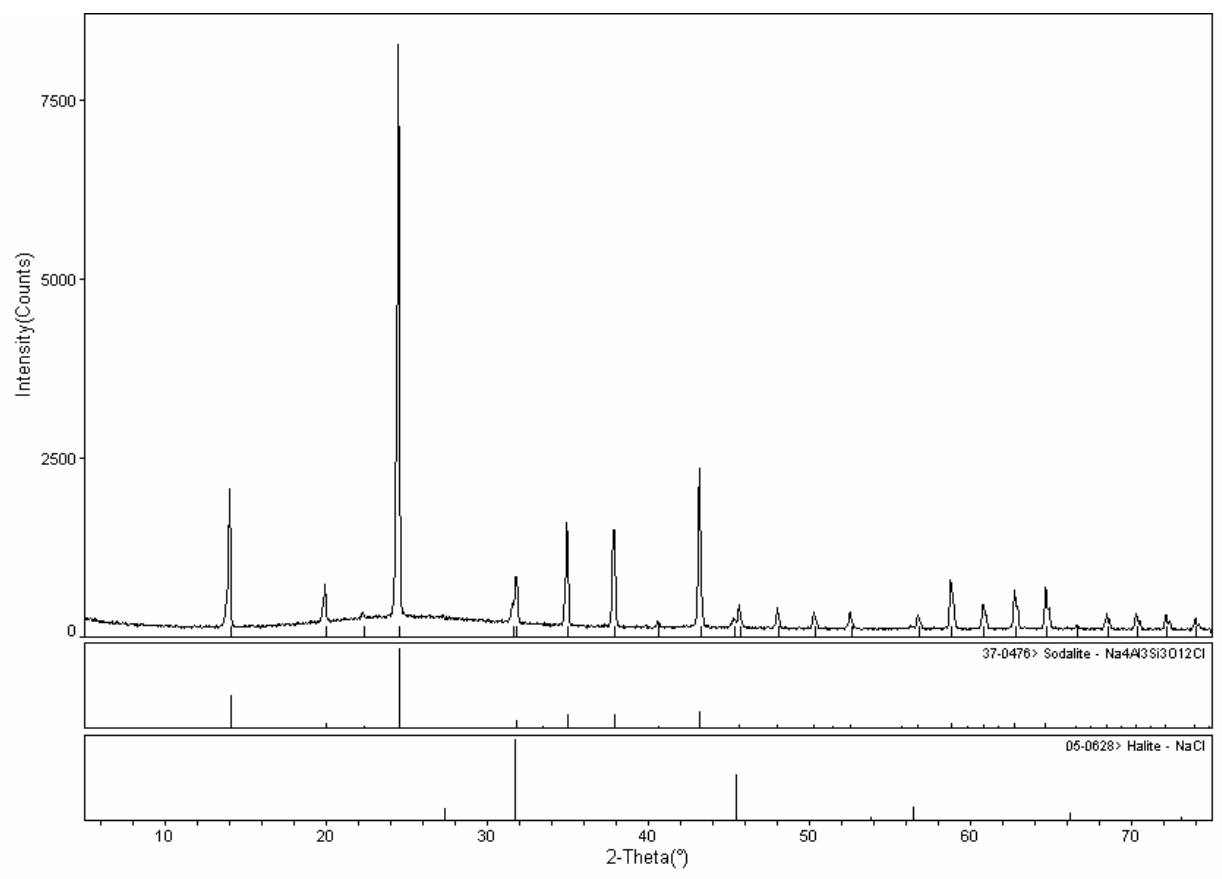

(d)

Fig. 8. (continued) 


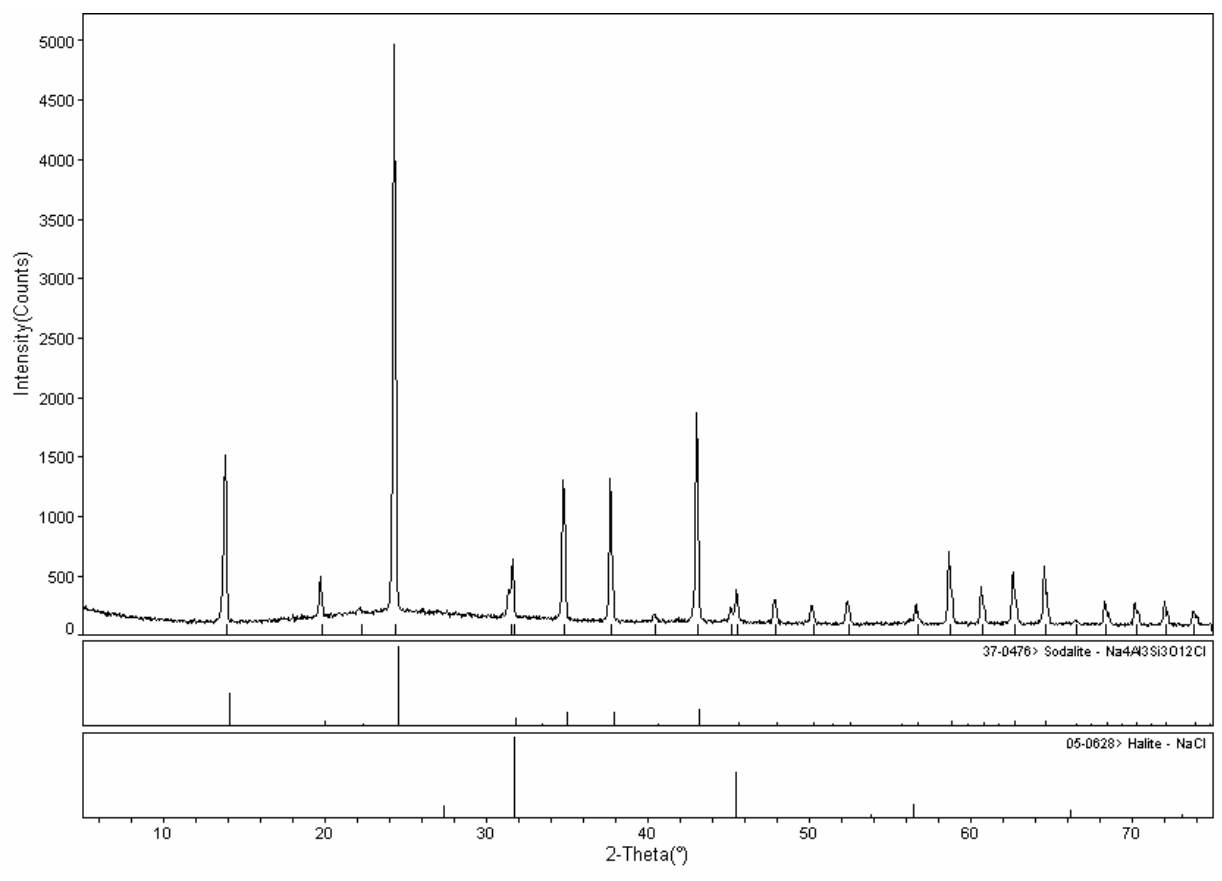

(e)

Fig. 8. (continued) 


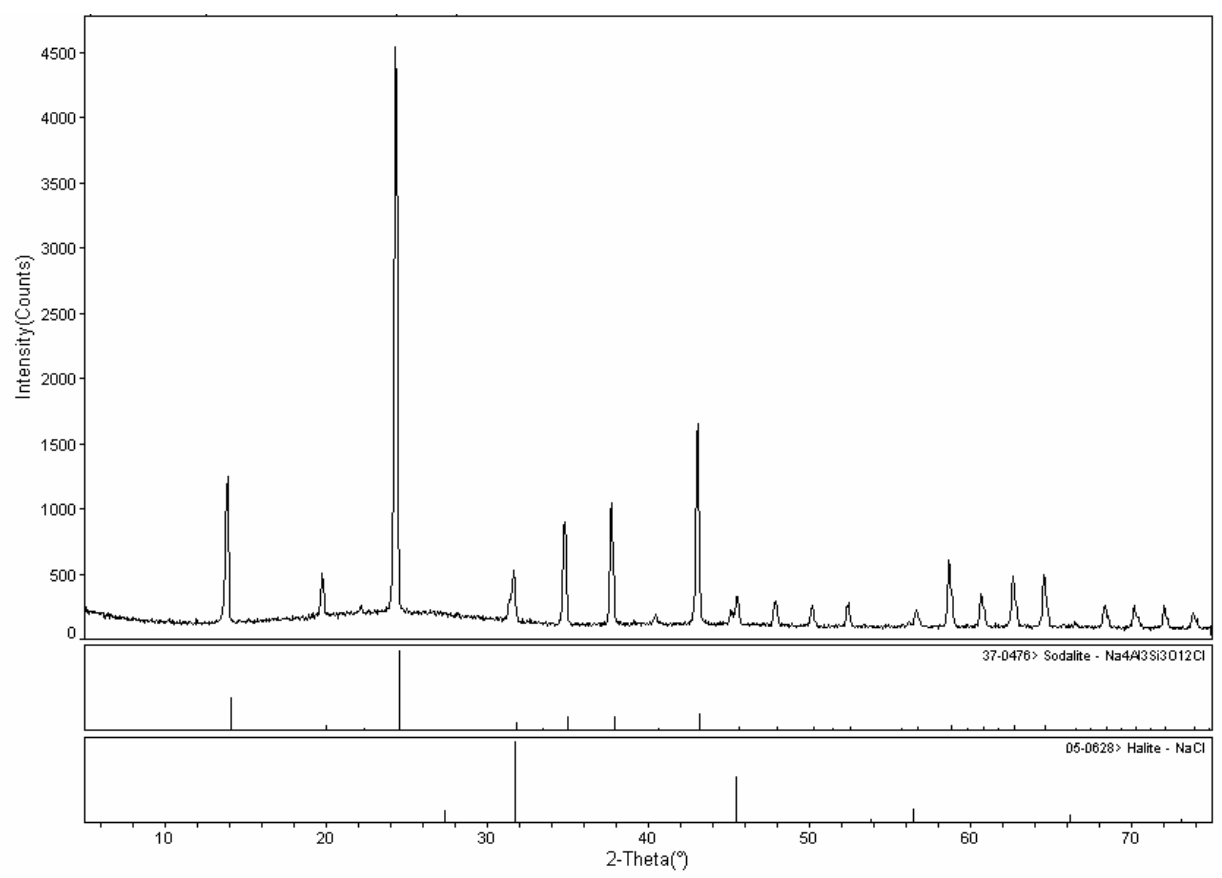

(a)

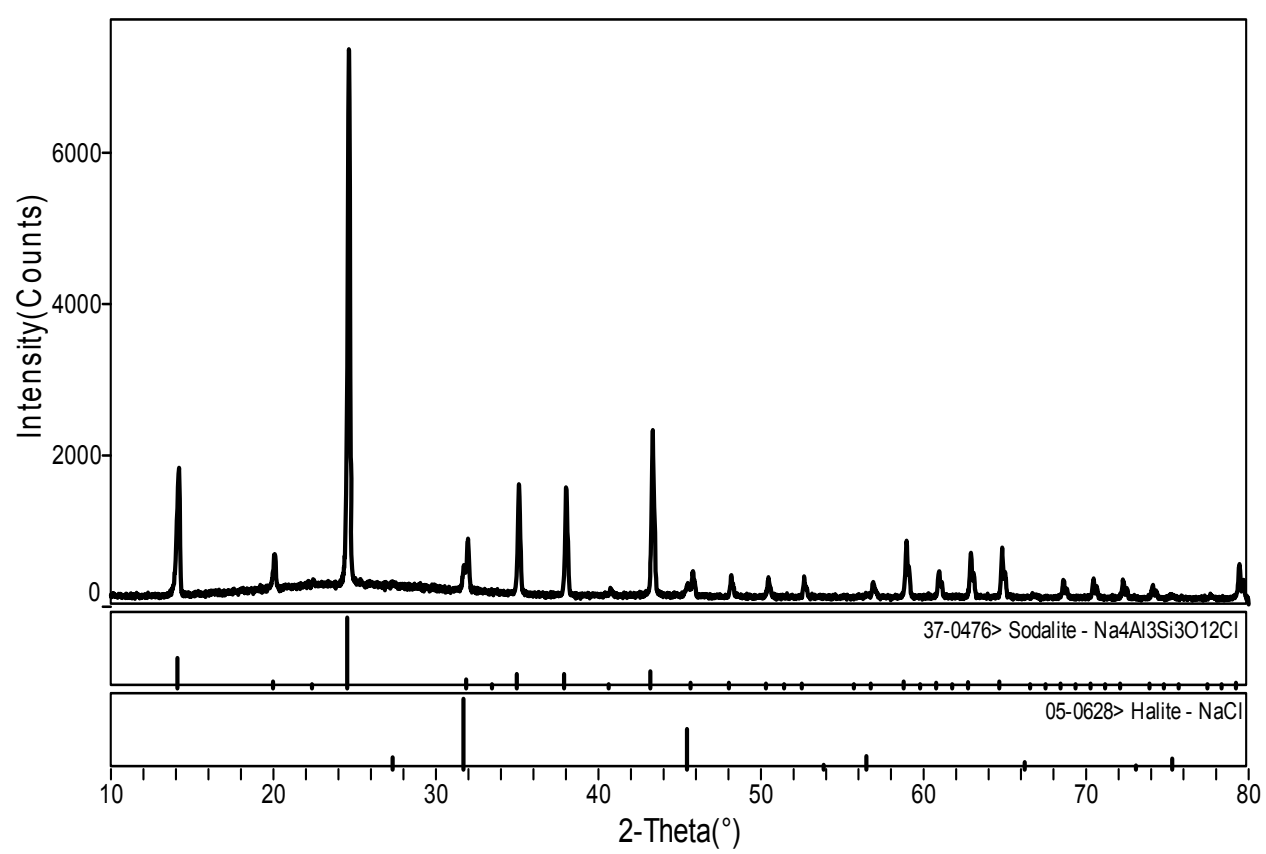

(b)

Fig. 9. XRD spectra of long-term heat-treated CWF samples heated at $500{ }^{\circ} \mathrm{C}$ : (a) 1 week, (b) 4 weeks, (c) 3 months, (d) 6 months, and (e) 1 year. 


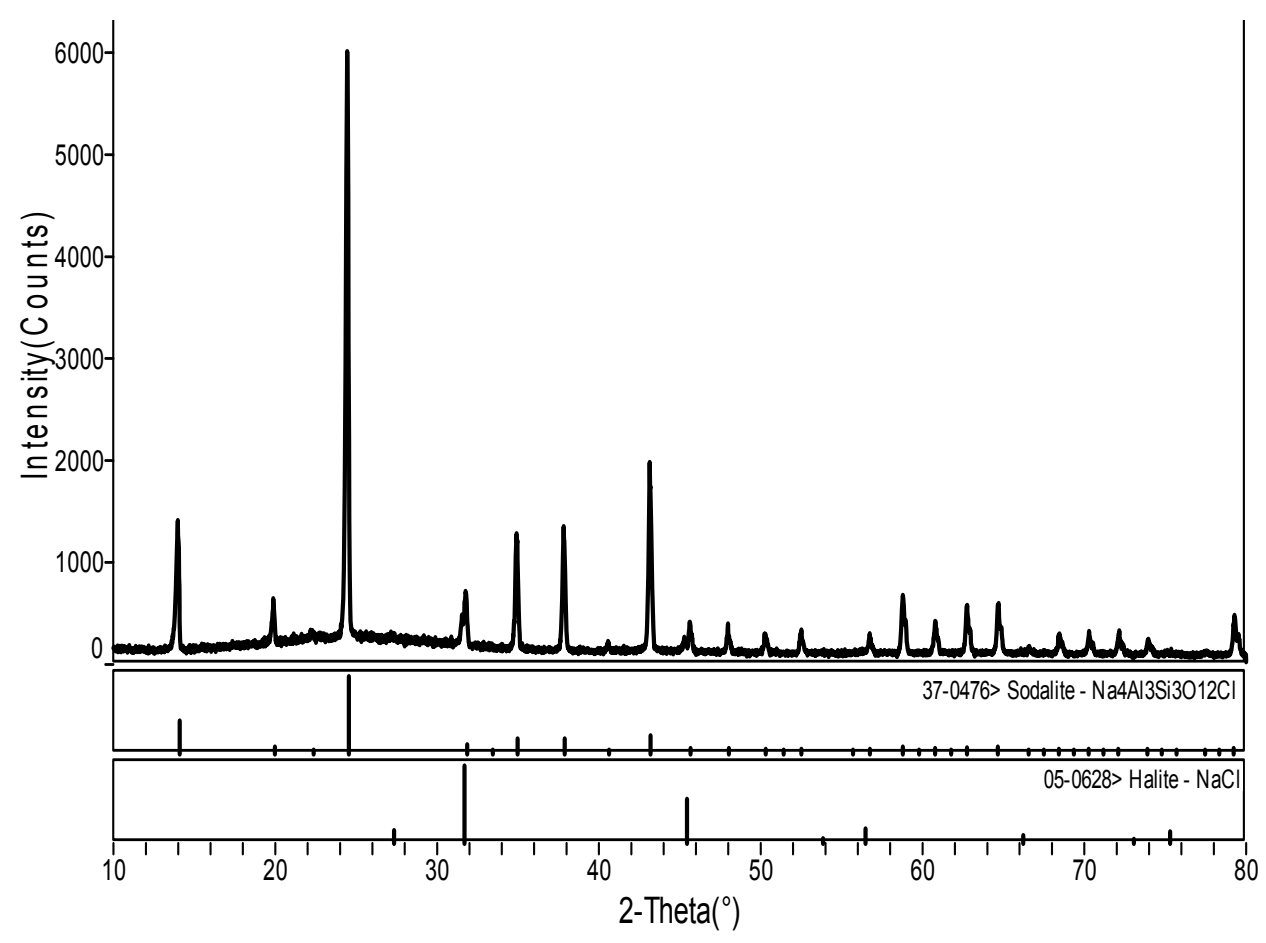

(c)

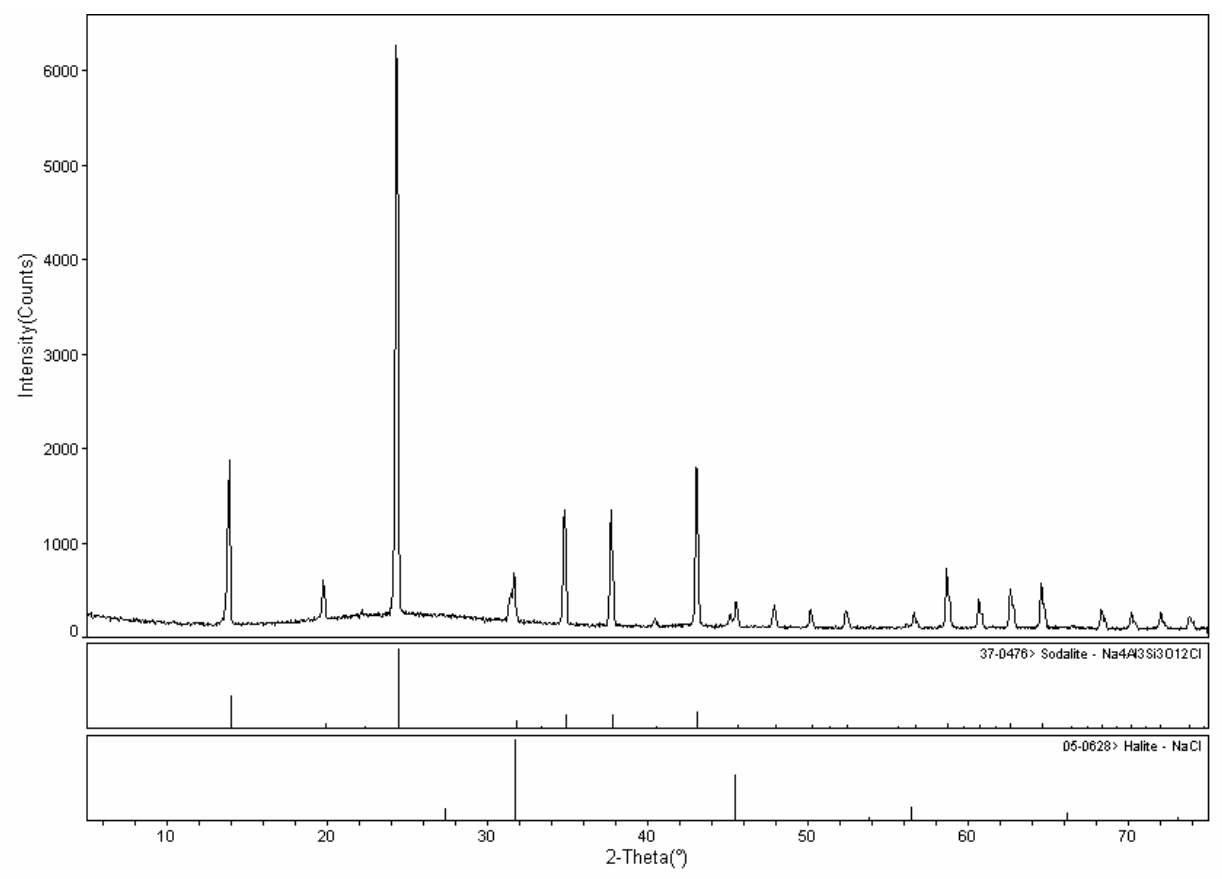

(d)

Fig. 9. (continued) 


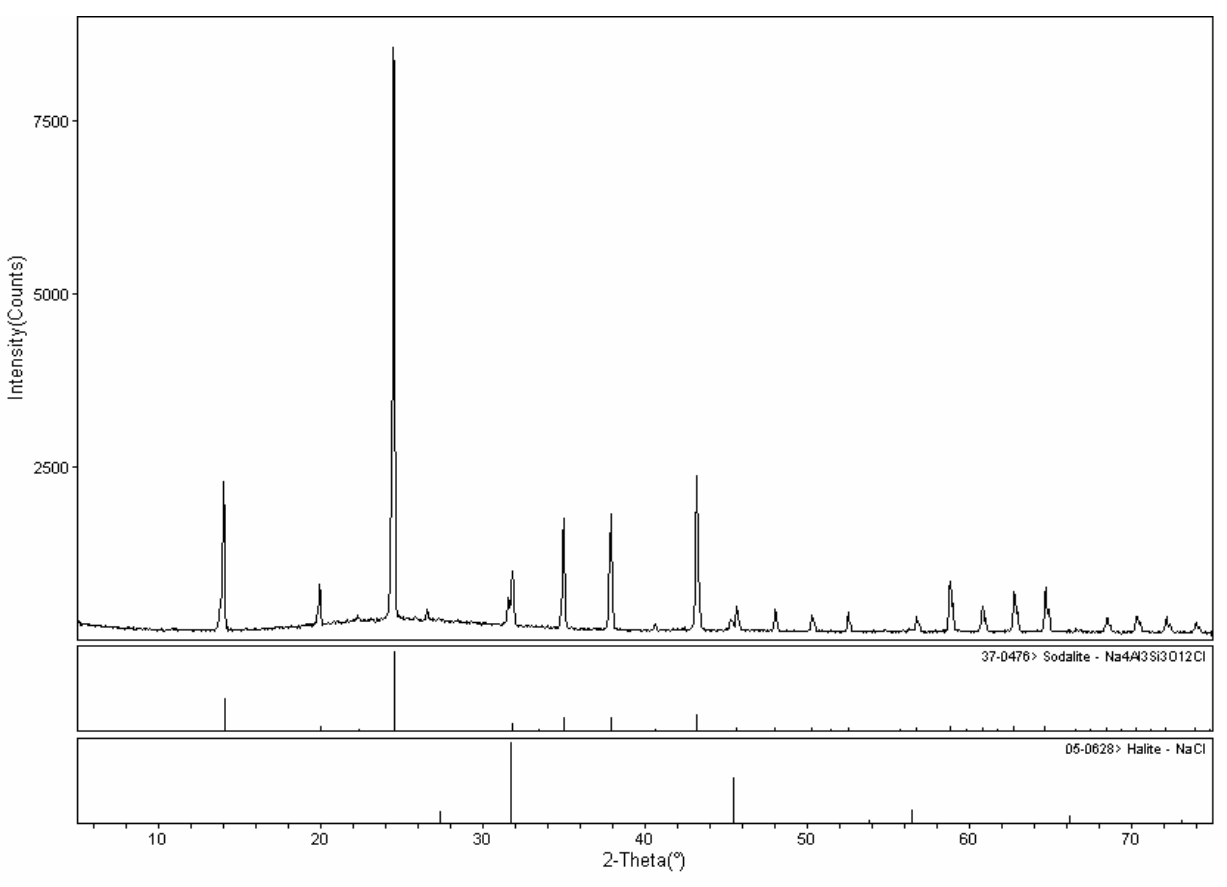

(e)

Fig. 9. (continued) 


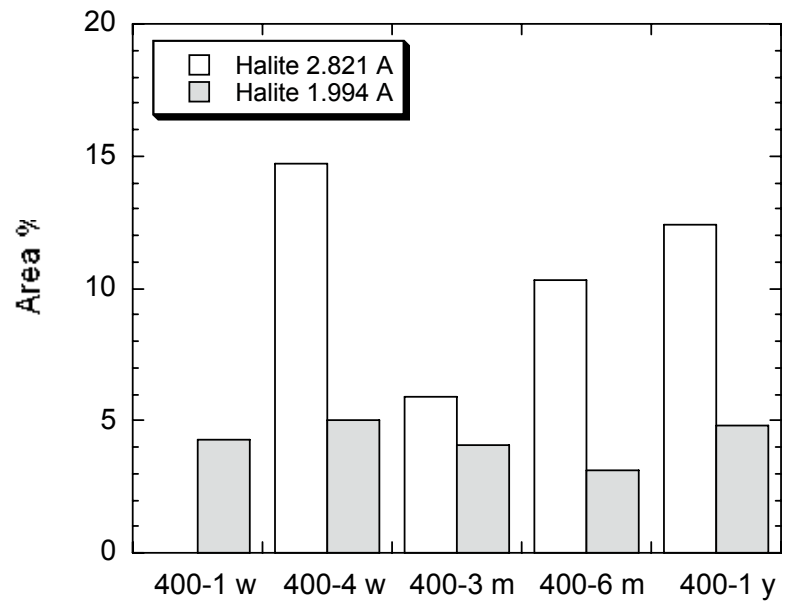

(a)

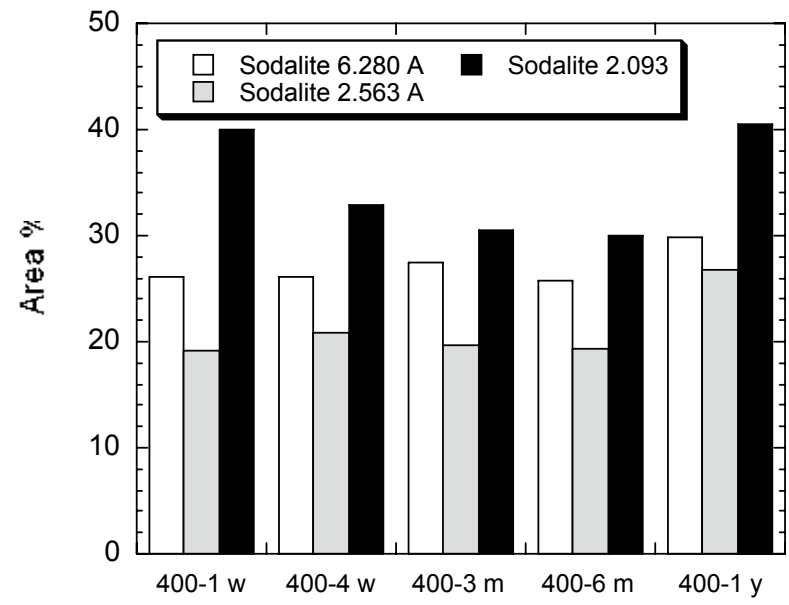

(c)

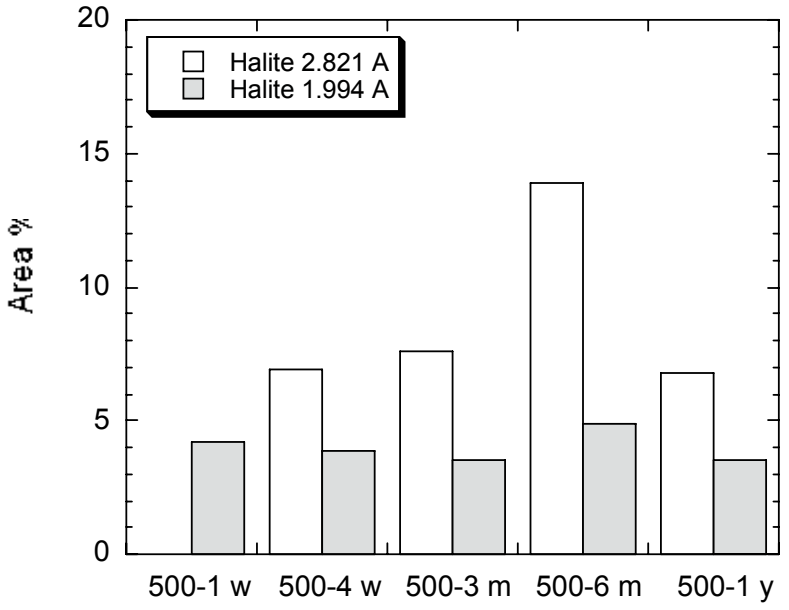

(b)

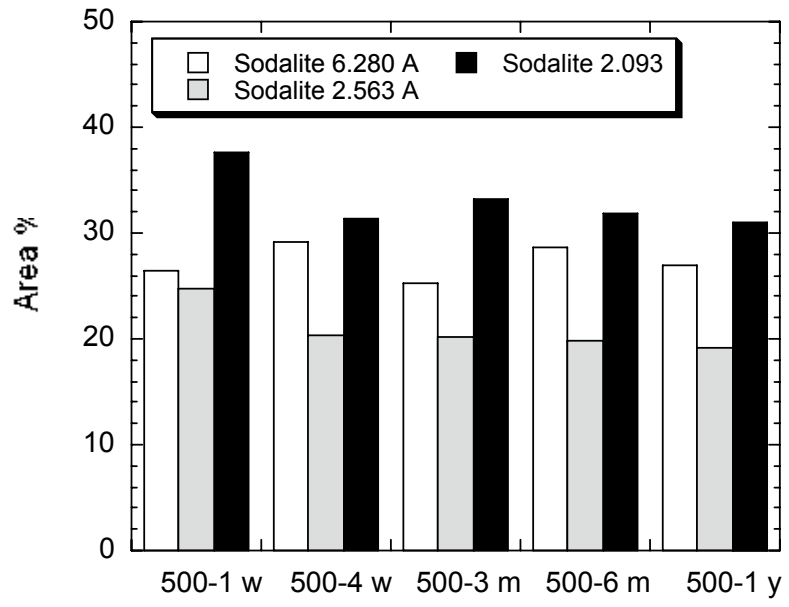

(d)

Fig. 10. Amounts of halite and sodalite in long-term heat-treated CWF samples heated for 1 week, 4 weeks, 3 months, 6 months, and 1 year (based on area\%): halite in samples heated at (a) $400{ }^{\circ} \mathrm{C}$ and (b) $500{ }^{\circ} \mathrm{C}$, and sodalite in samples heated at (c) $400{ }^{\circ} \mathrm{C}$ and (d) $500{ }^{\circ} \mathrm{C}$. 


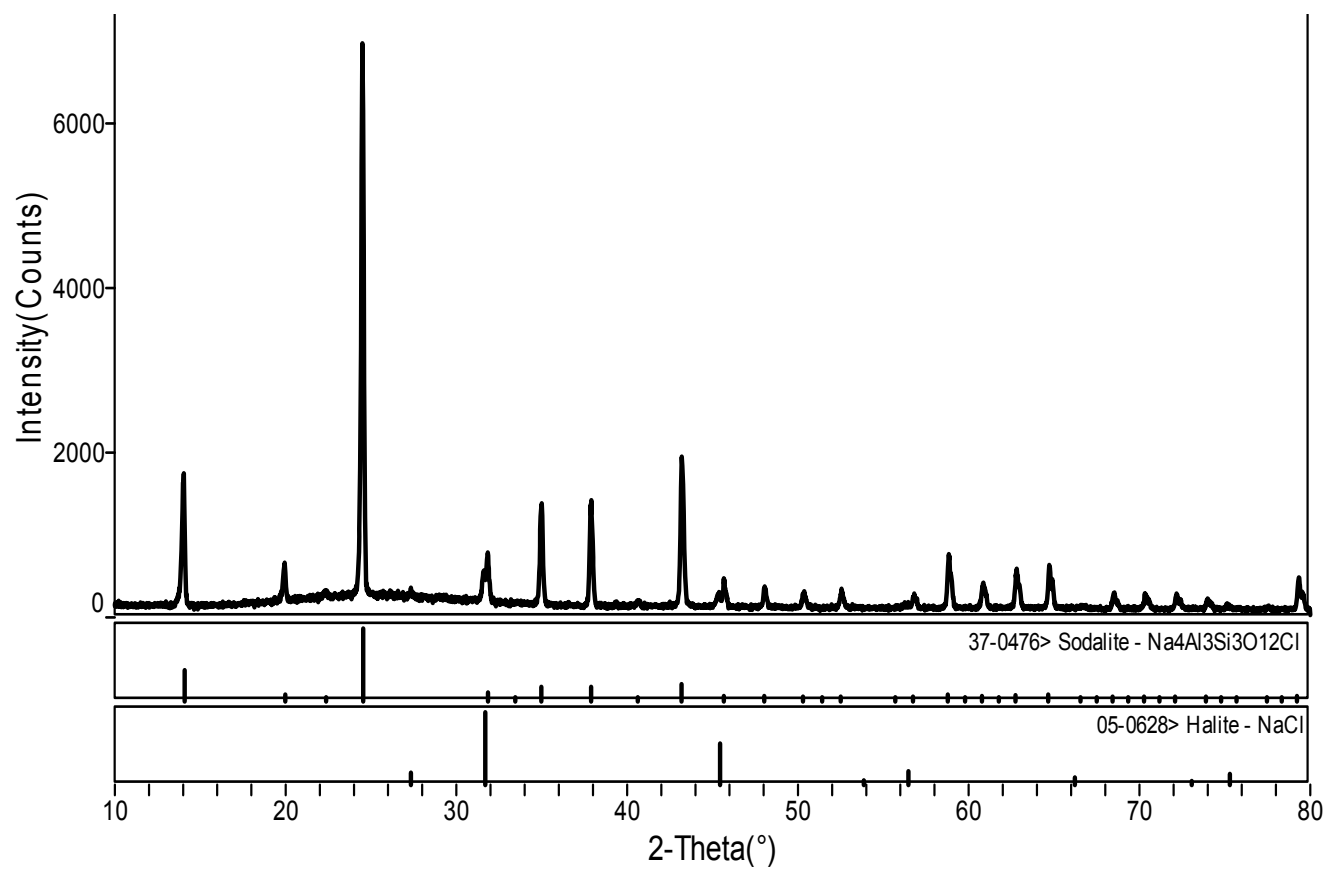

Fig. 11. XRD spectrum of CWF source material PC10402 that was not heat-treated. 


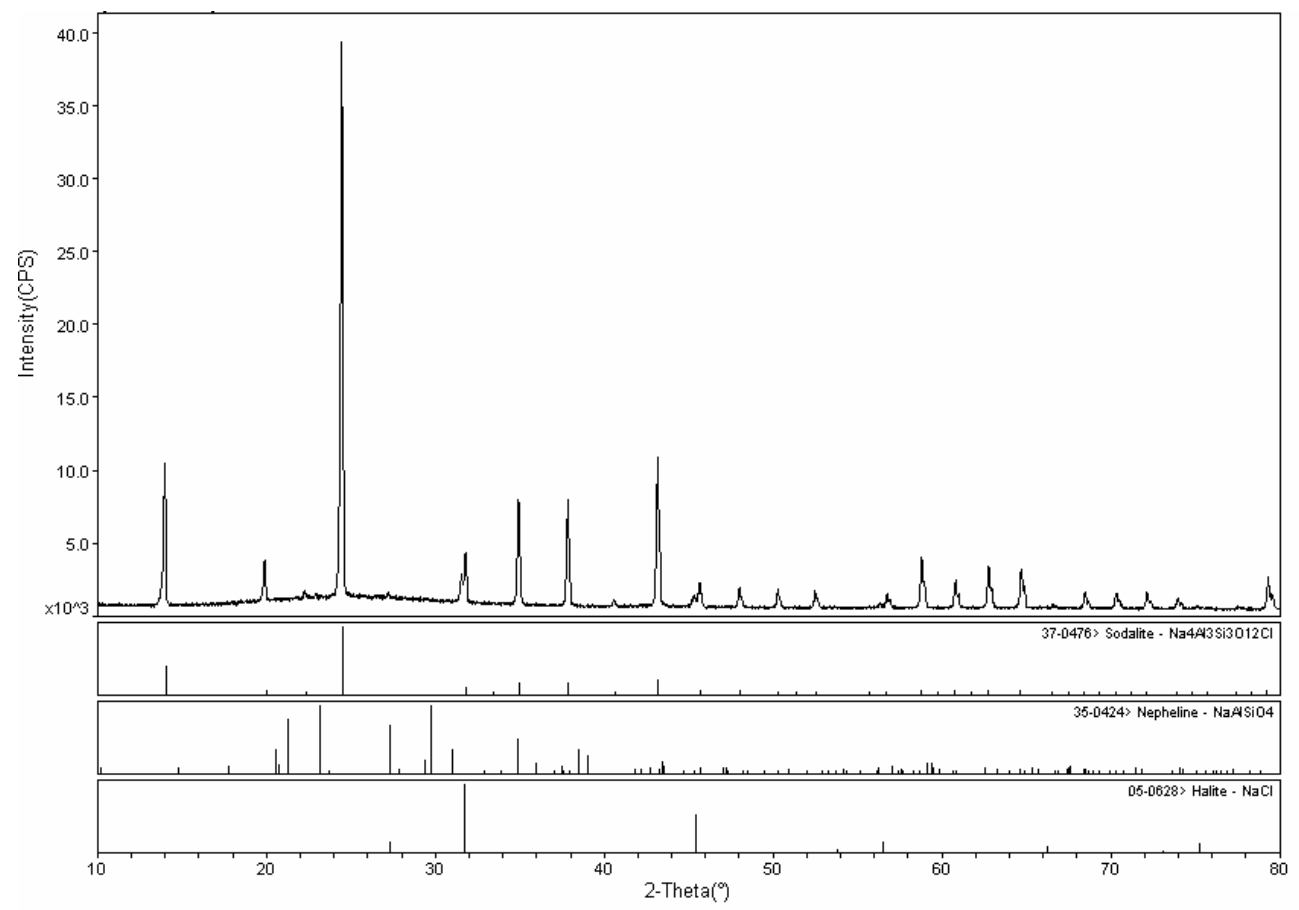

(a)

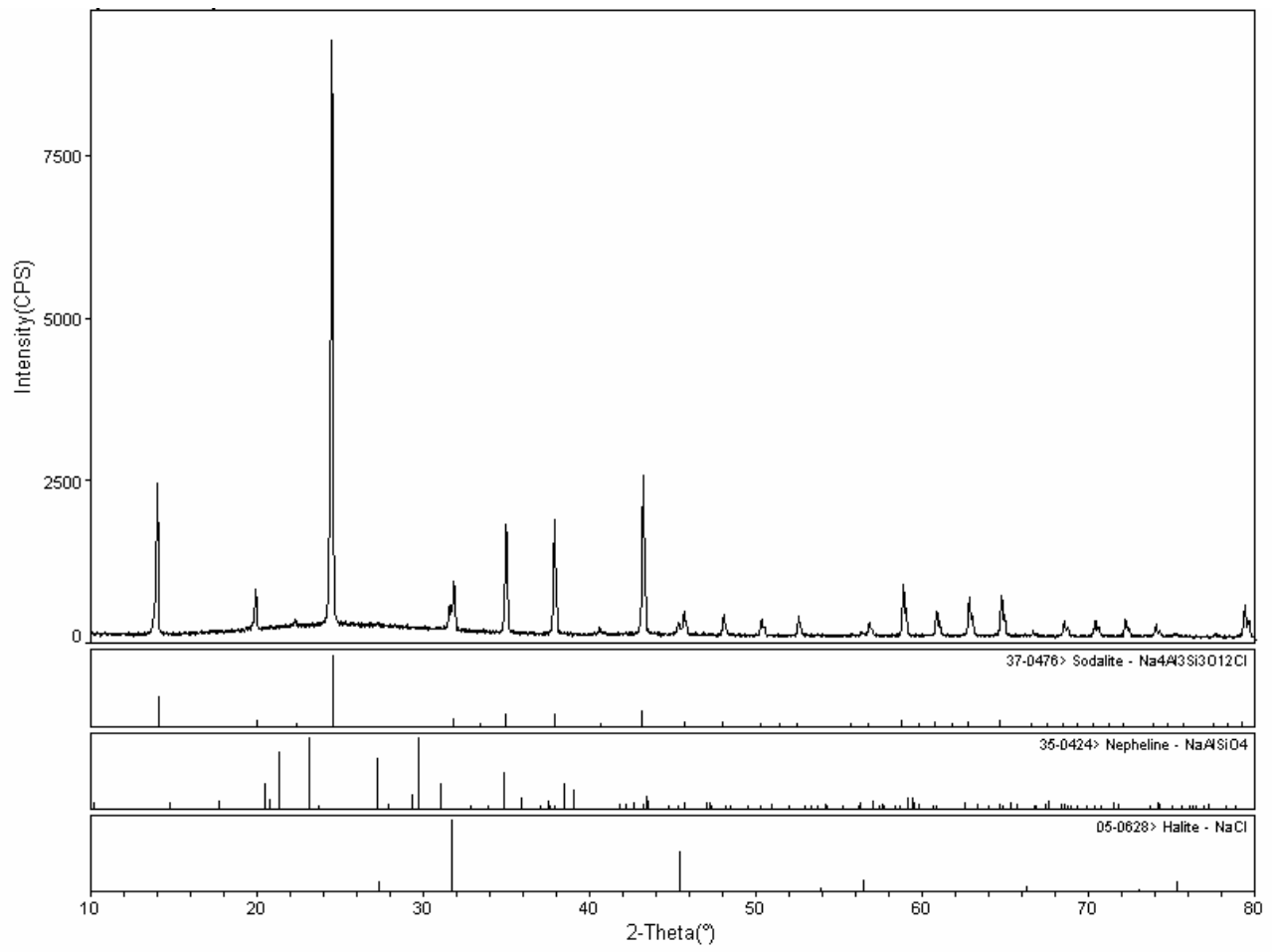

(b)

Fig. 12. XRD spectra of short-term heat-treated CWF samples heated at $600{ }^{\circ} \mathrm{C}$ : (a) 4 hours, (b) 28 hours, (c) 52 hours, and (d) 100 hours. 


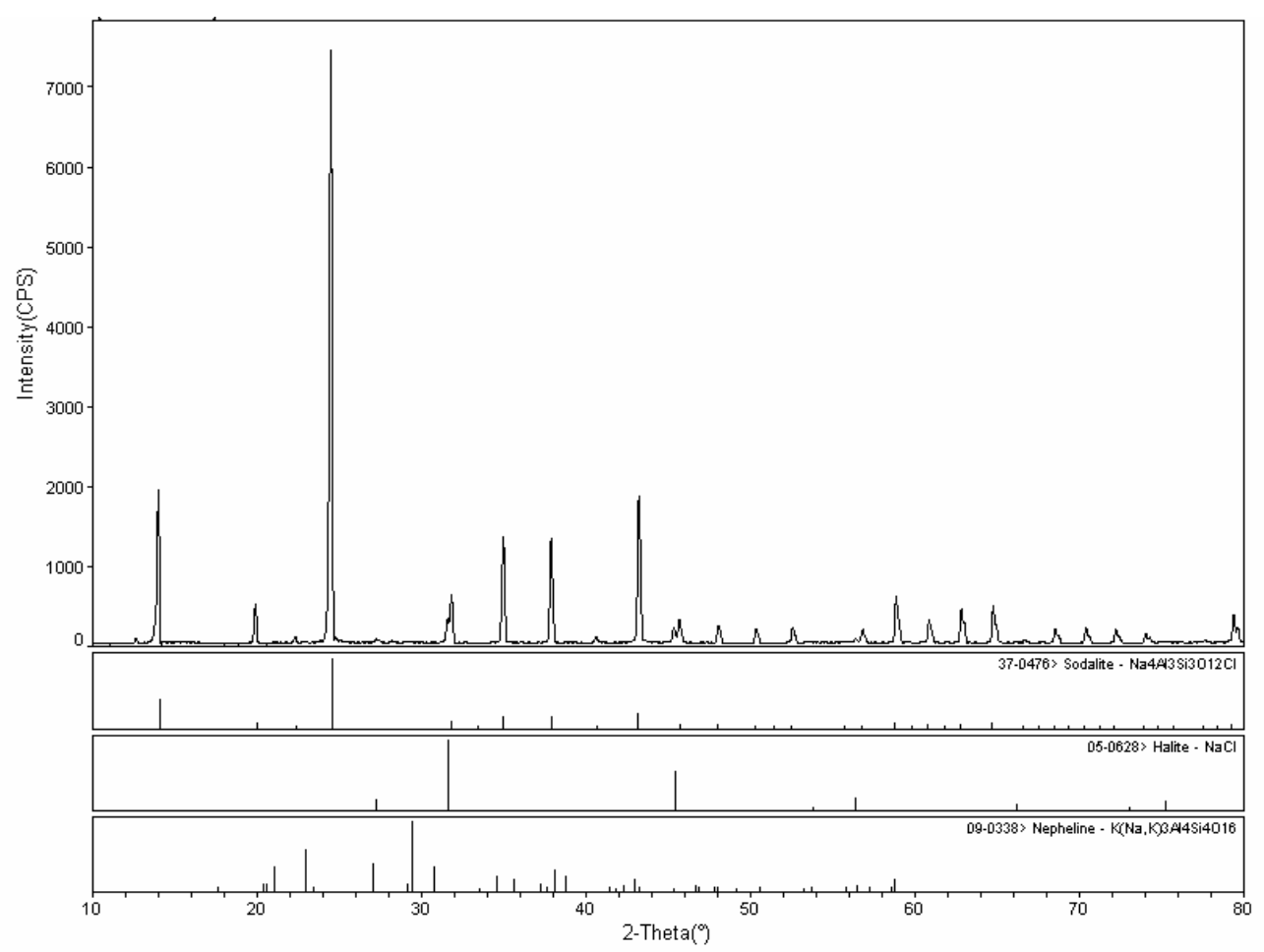

(c)

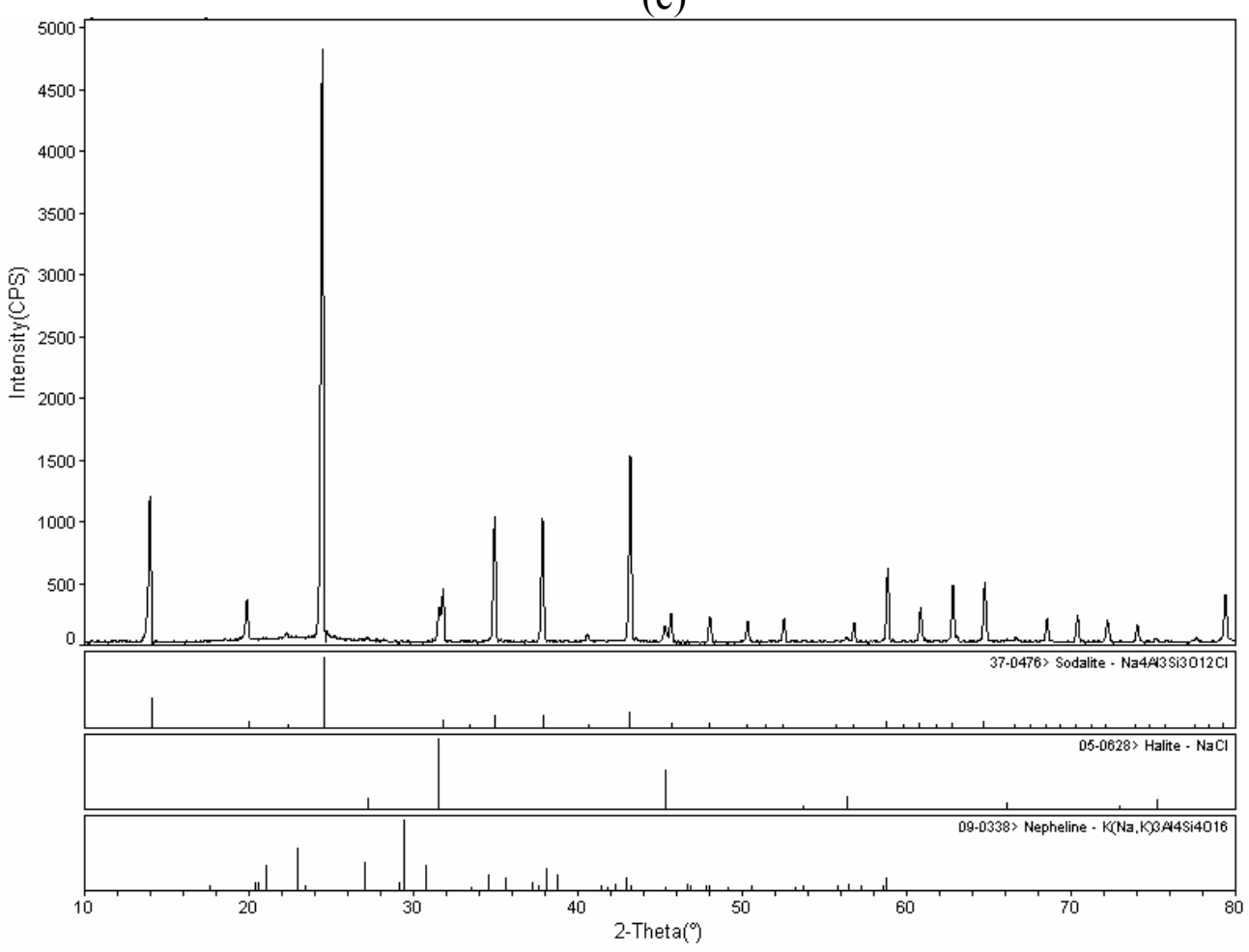

(d)

Fig. 12. (continued) 


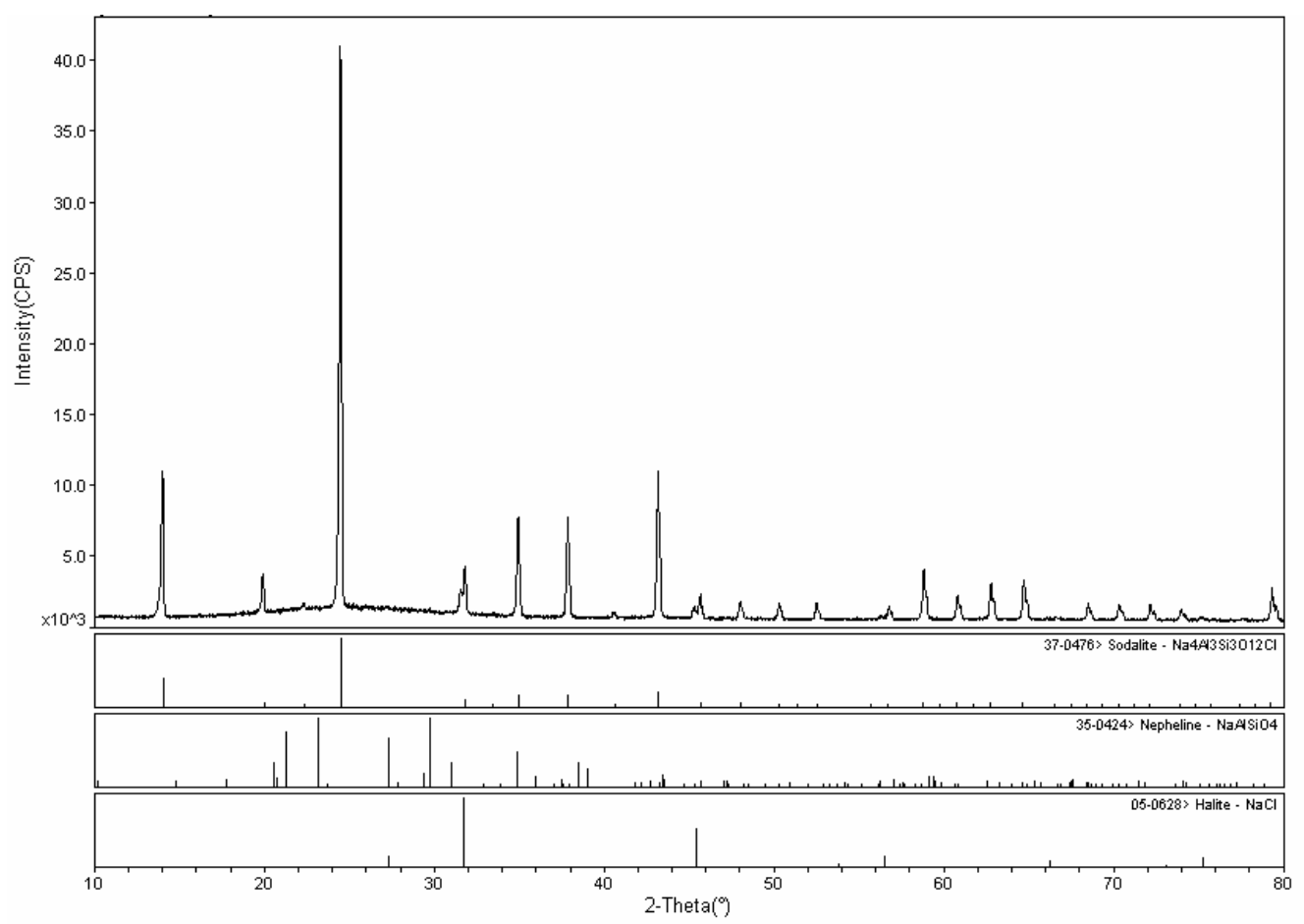

(a)

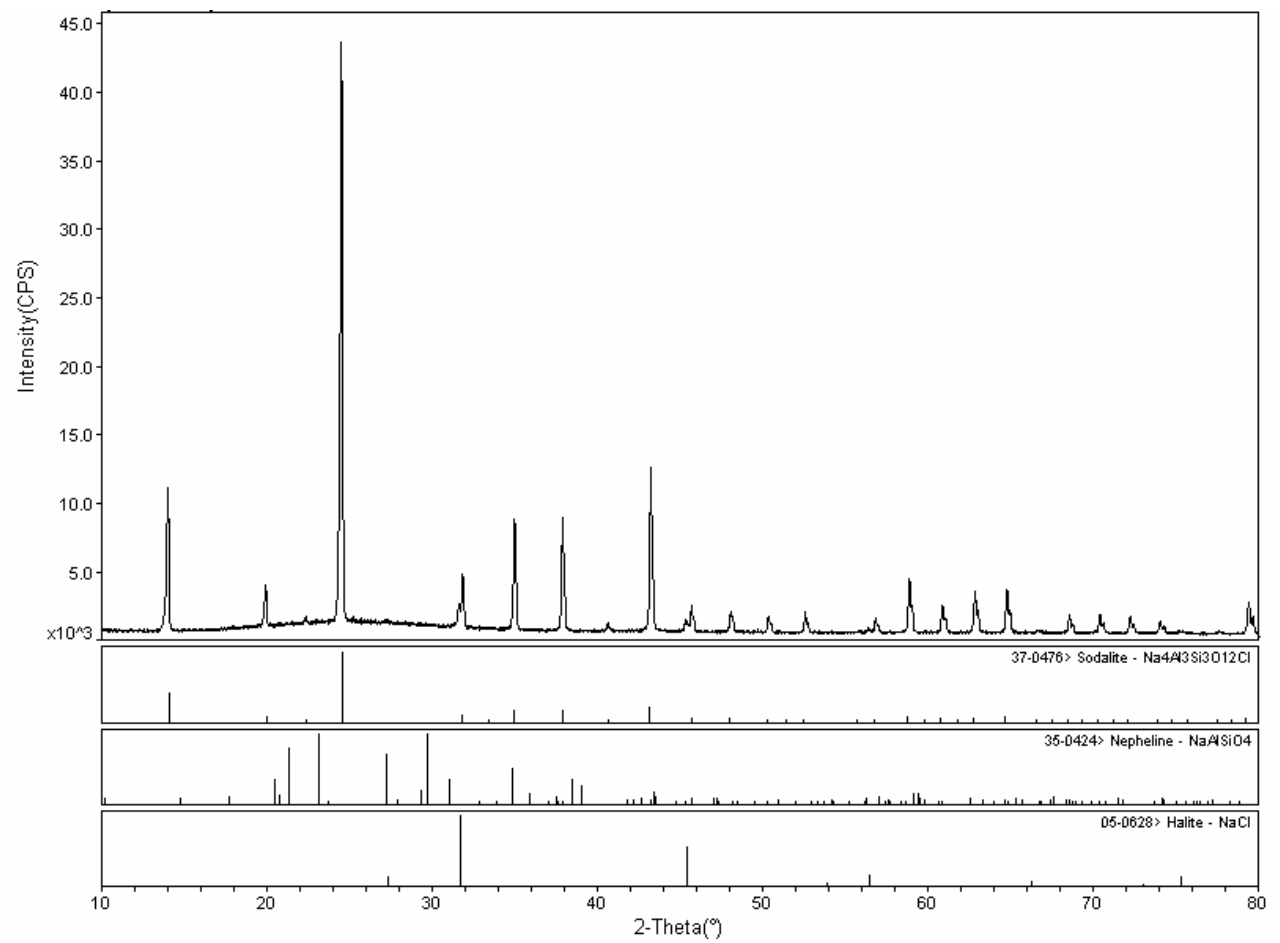

(b)

Fig. 13. XRD spectra of short-term heat-treated CWF samples heated at $700{ }^{\circ} \mathrm{C}$ : (a) 4 hours, (b) 28 hours, (c) 52 hours, and (d) 100 hours. 


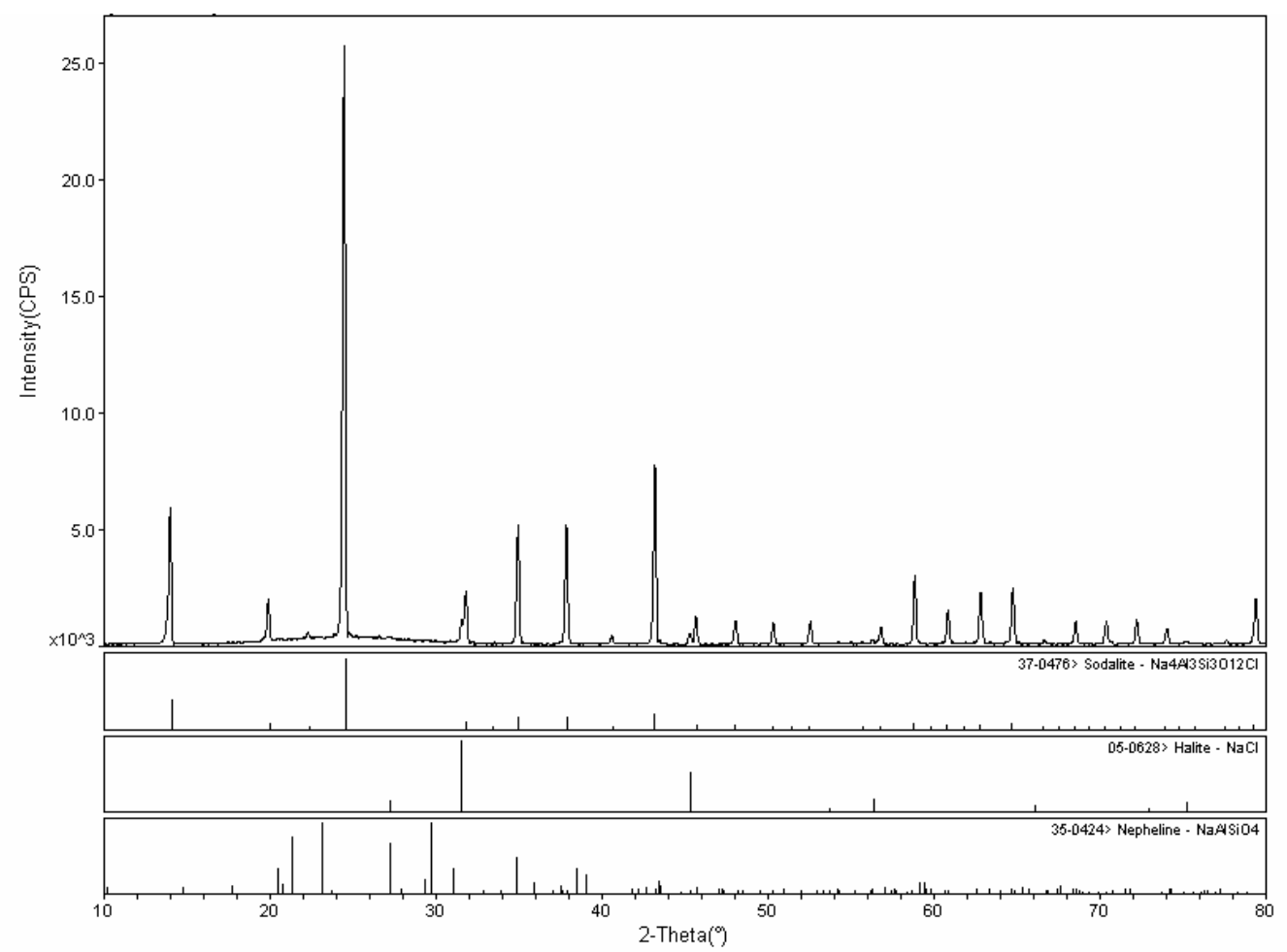

(c)

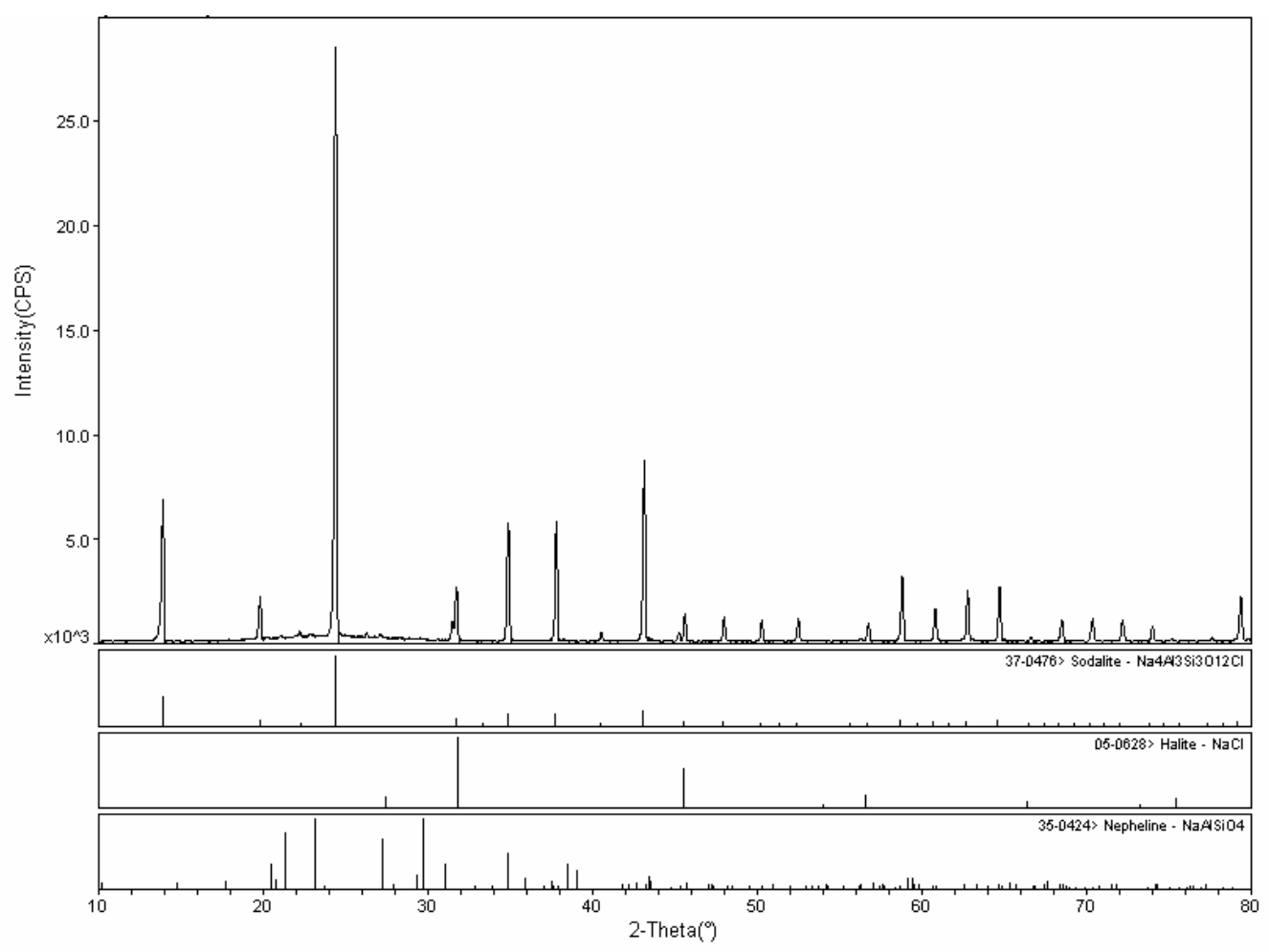

(d)

Fig. 13. (continued) 


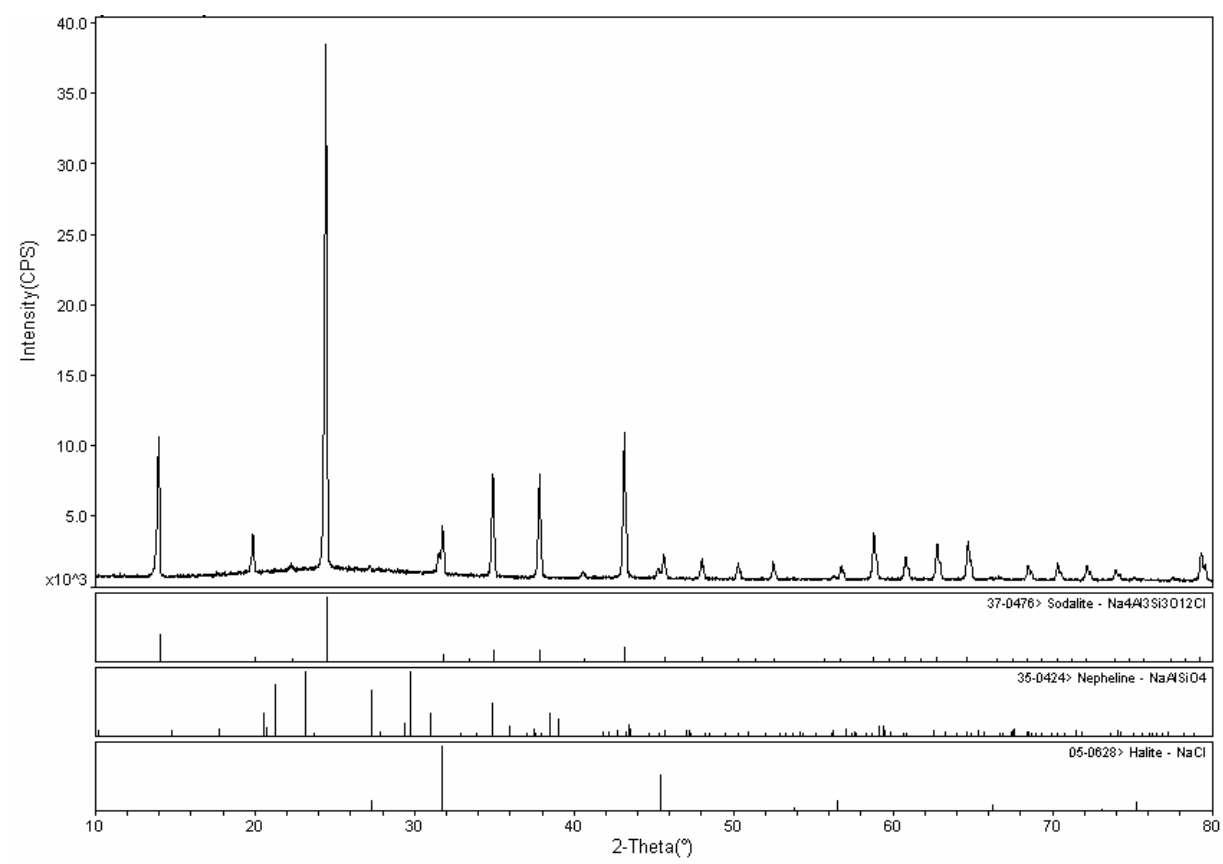

(a)

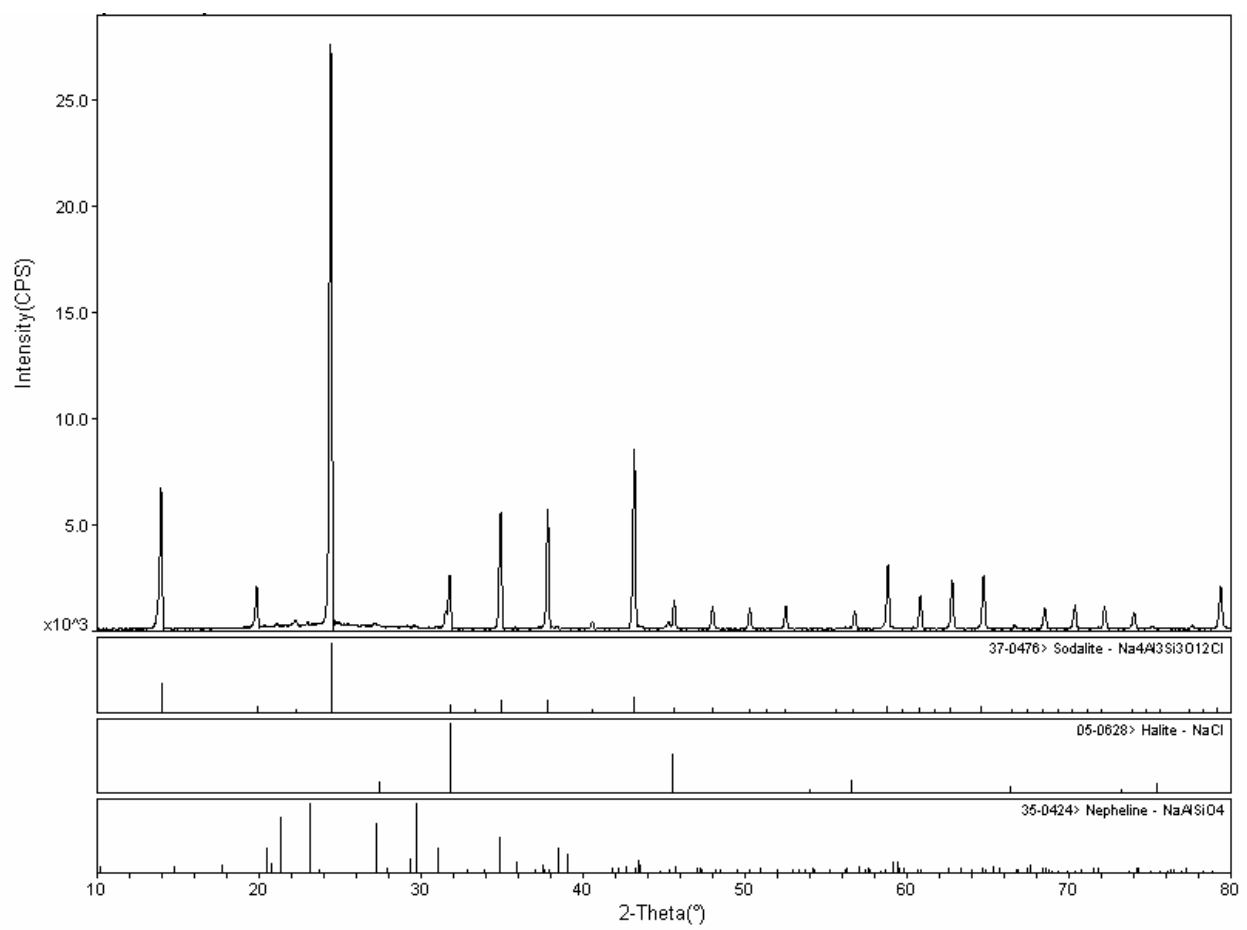

(b)

Fig. 14. XRD spectra of short-term heat-treated CWF samples heated at $800^{\circ} \mathrm{C}$ : (a) 4 hours, (b) 28 hours, (c) 52 hours, and (d) 100 hours. 


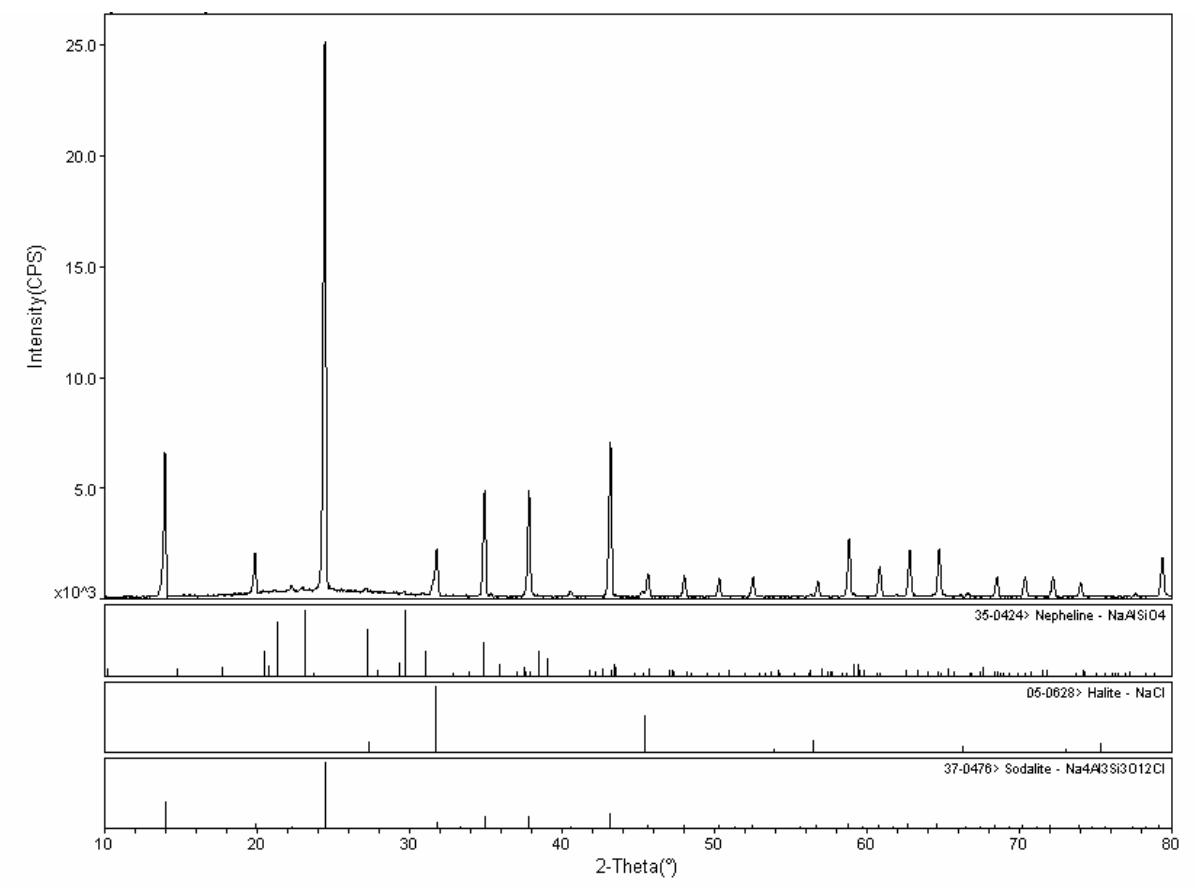

(c)

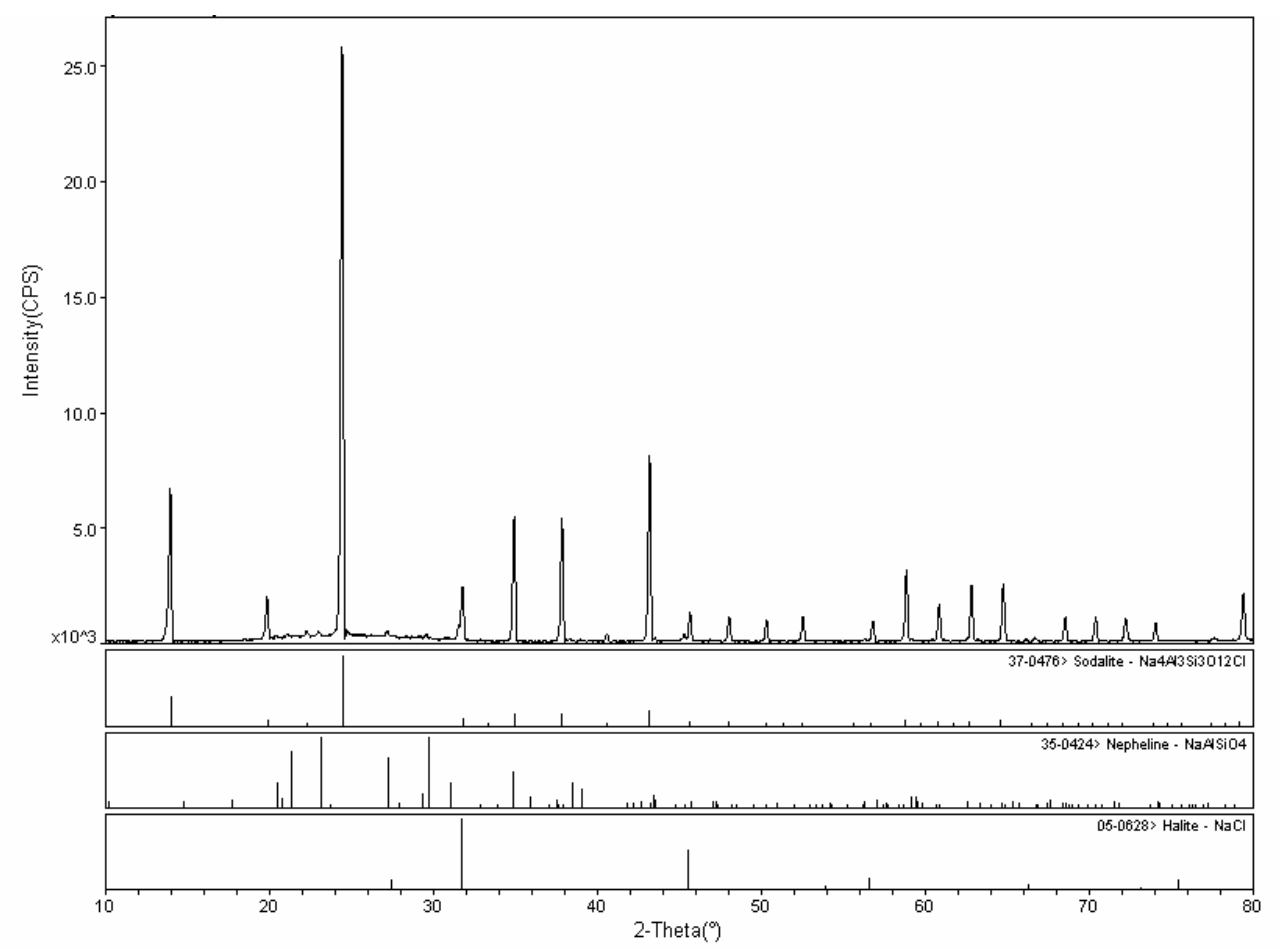

(d)

Fig. 14. (continued) 


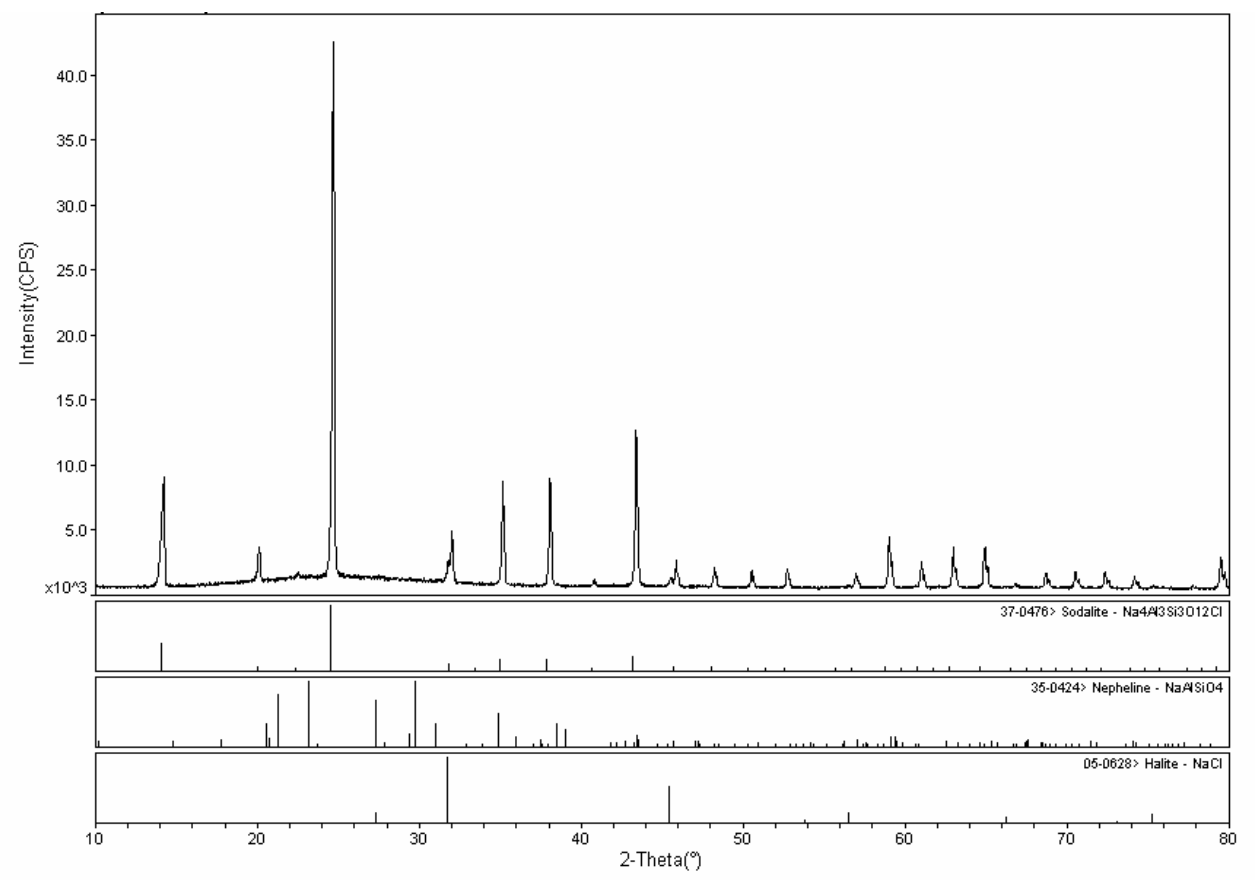

(a)

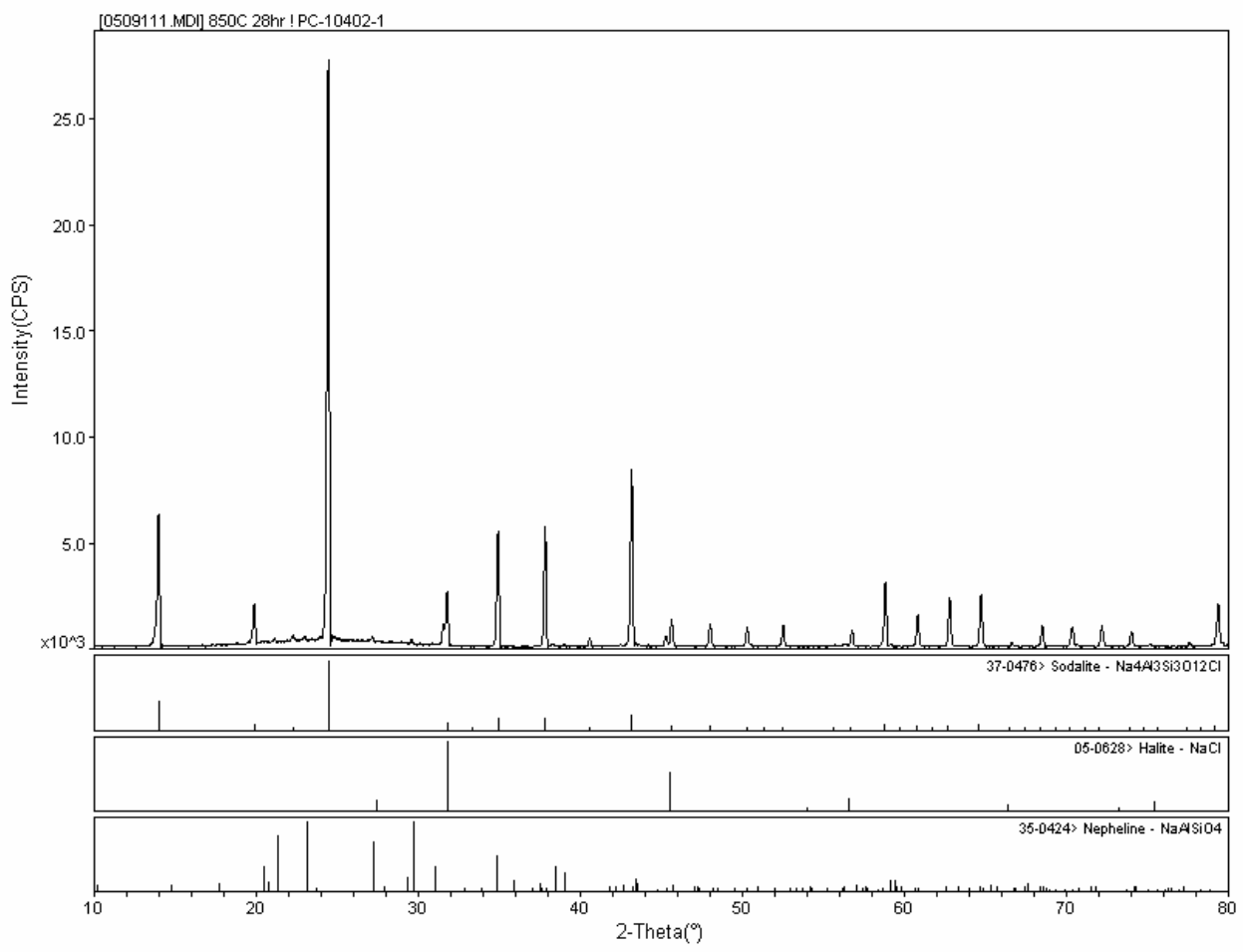

(b)

Fig. 15. XRD spectra of short-term heat-treated CWF samples heated at $850{ }^{\circ} \mathrm{C}$ : (a) 4 hours, (b) 28 hours, (c) 52 hours, and (d) 100 hours. 


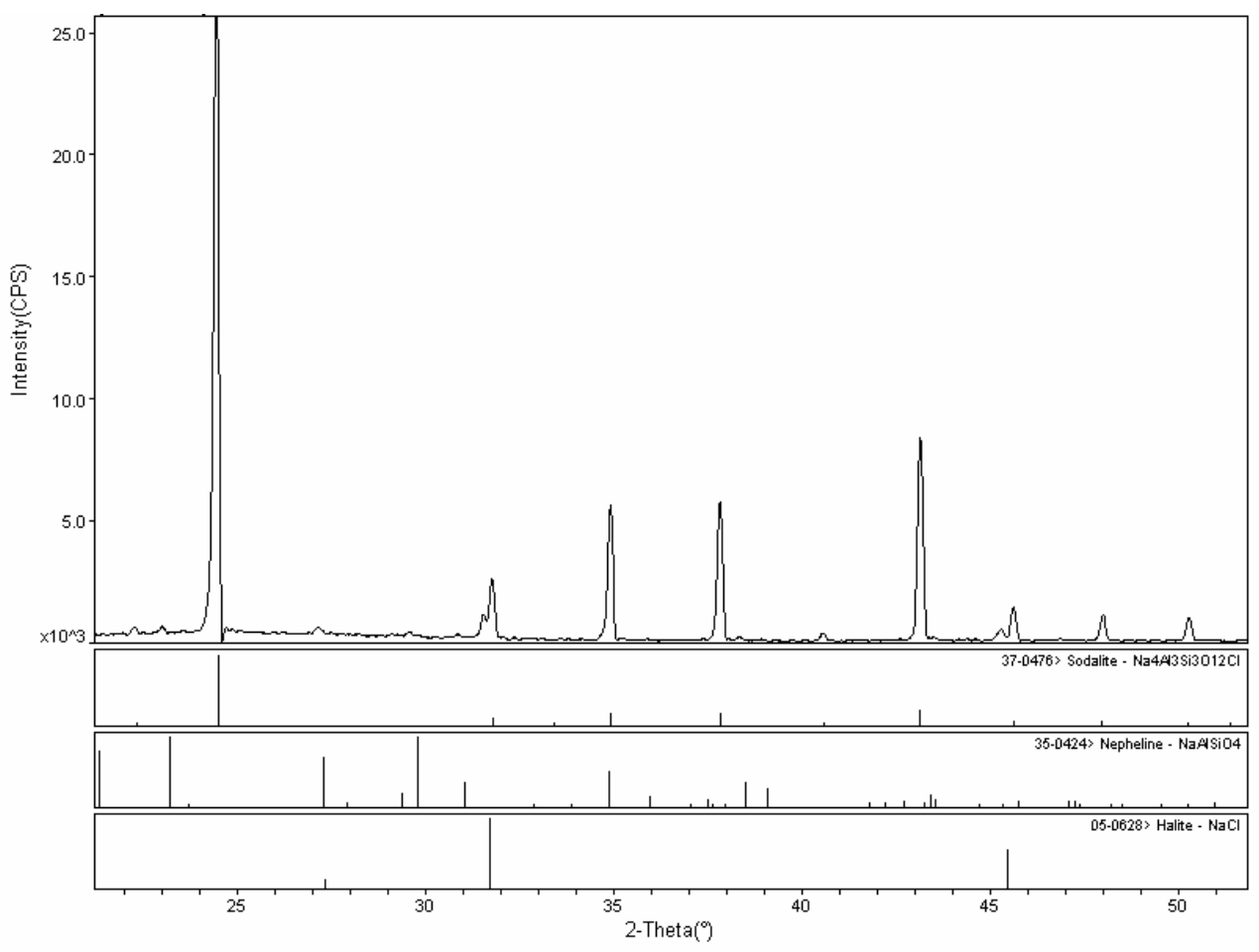

(c)

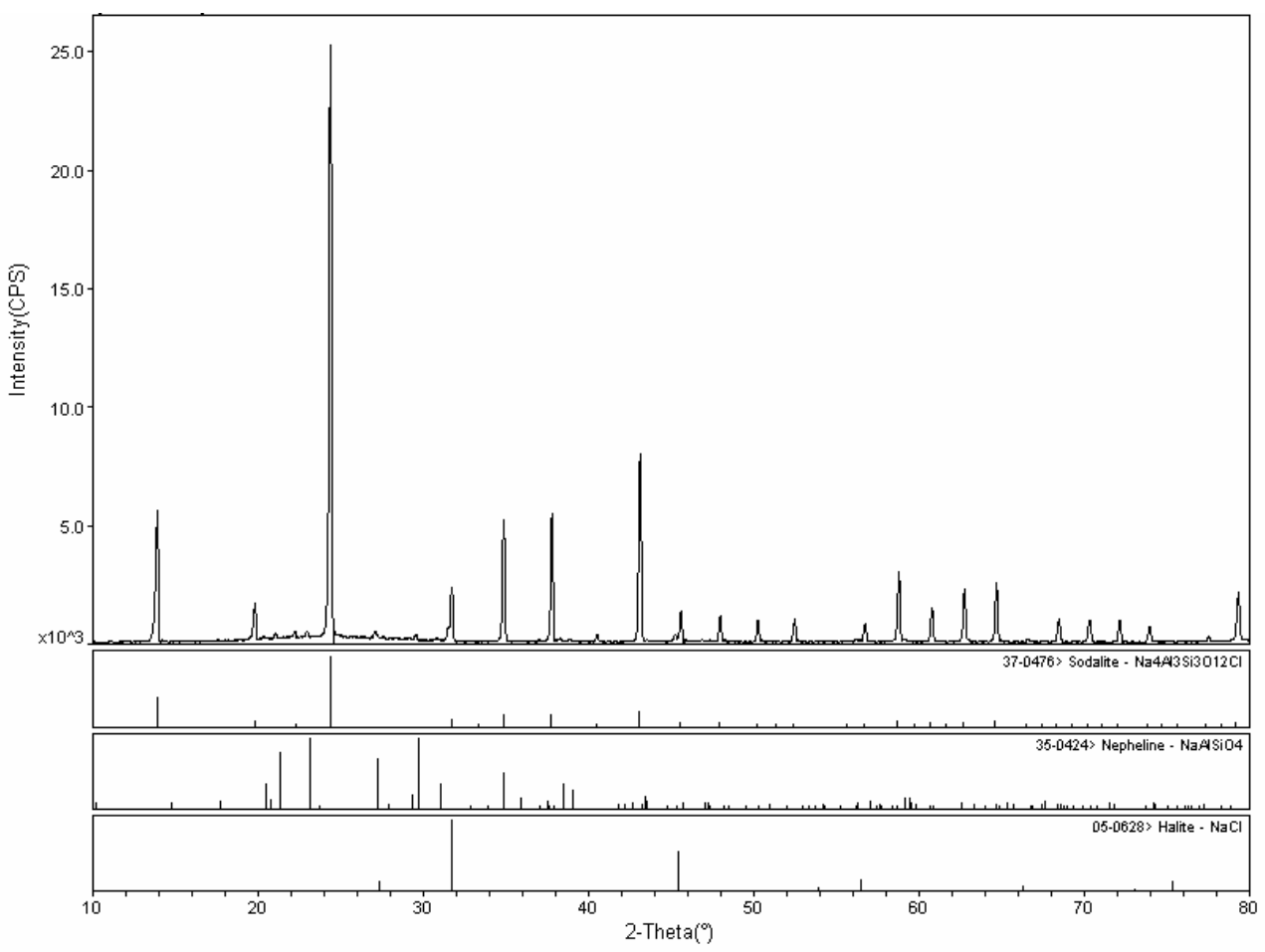

(d)

Fig. 15. (continued) 


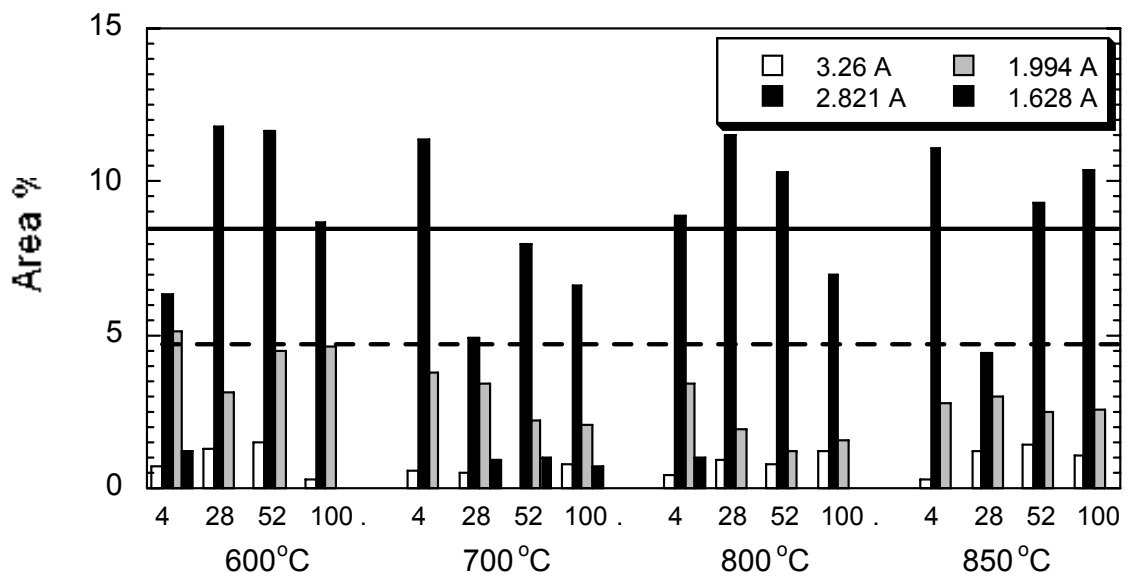

(a)

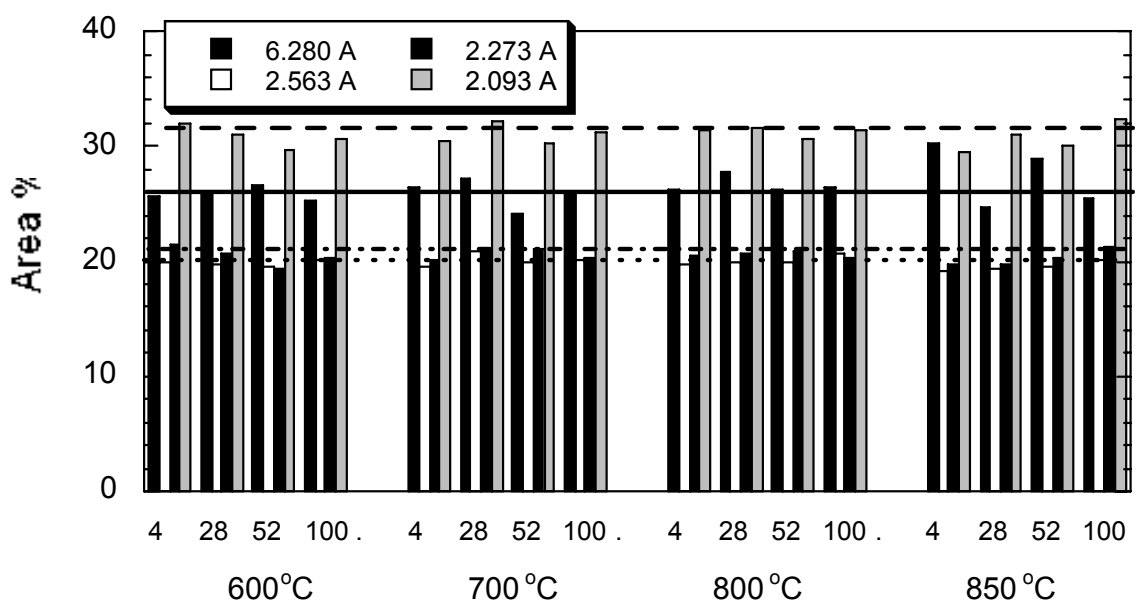

(b)

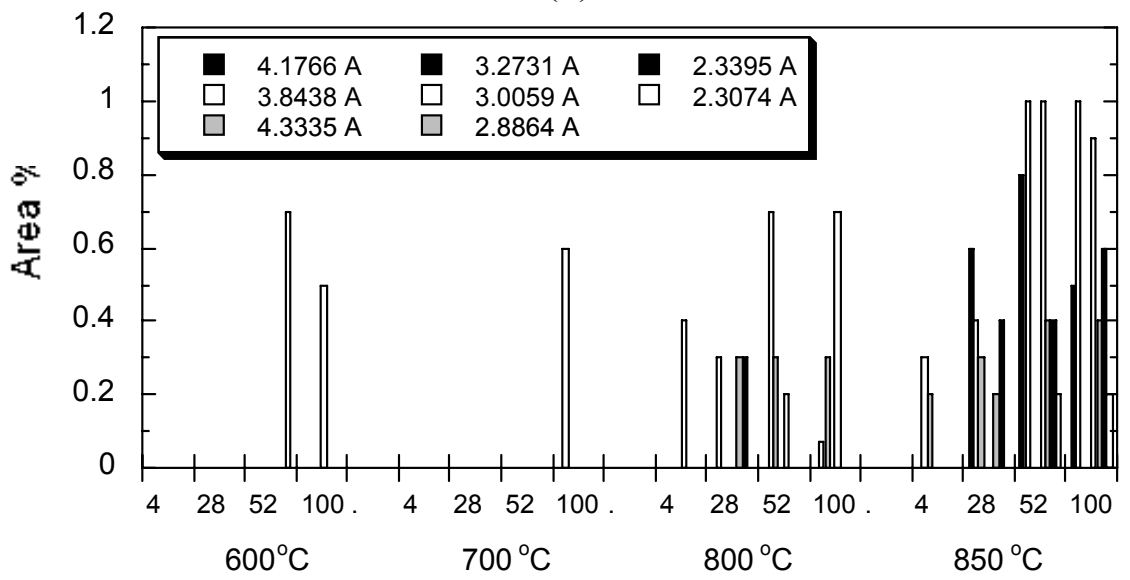

(c)

Fig. 16. Relative amounts of (a) halite, (b) sodalite, and (c) nepheline in short-term heat-treated CWF samples heated for $4,28,52$, or 100 hours at $600,700,800$, or $850{ }^{\circ} \mathrm{C}$ (based on area\%). Horizontal lines show mean values measured for CWF source material PC10402 without heat treatment. 


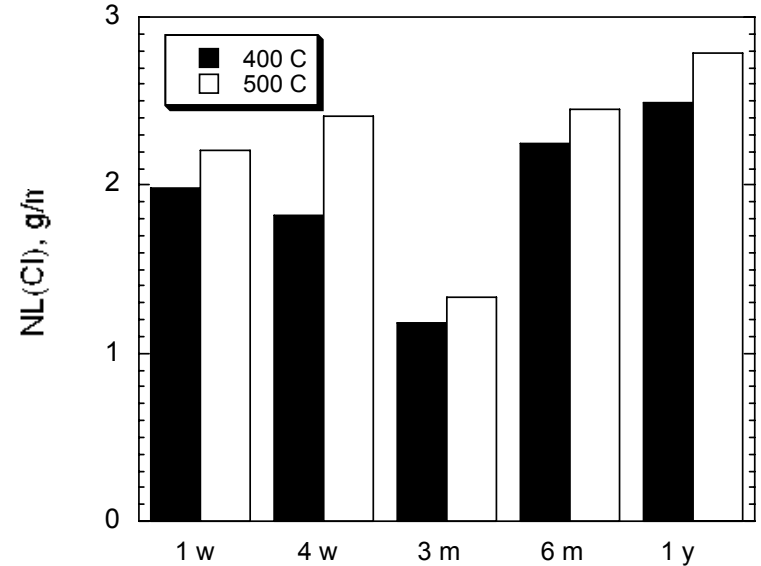

(a)

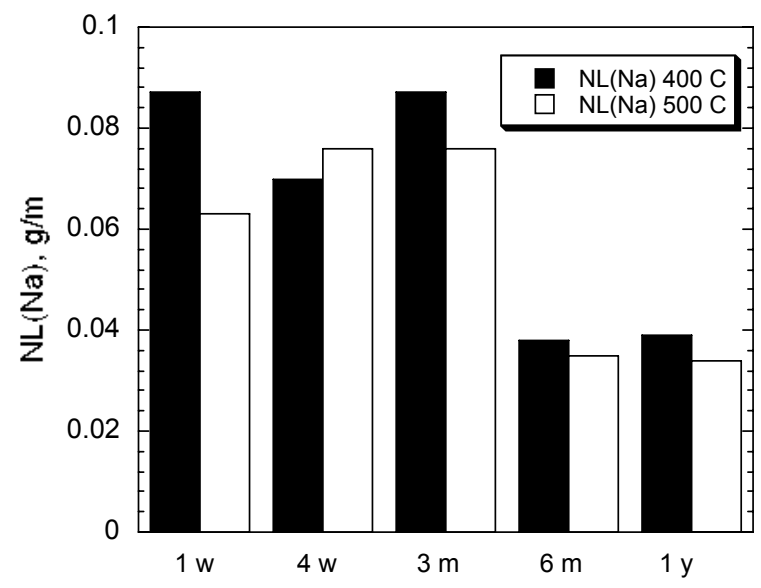

(c)

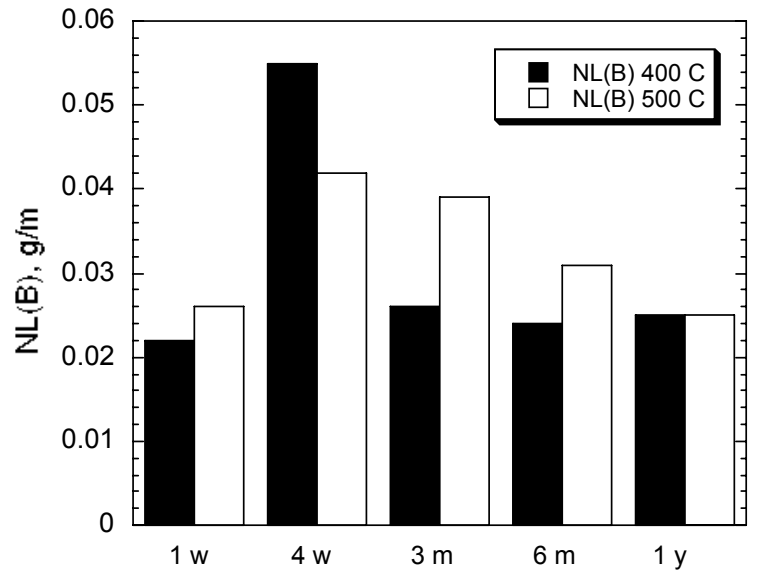

(b)

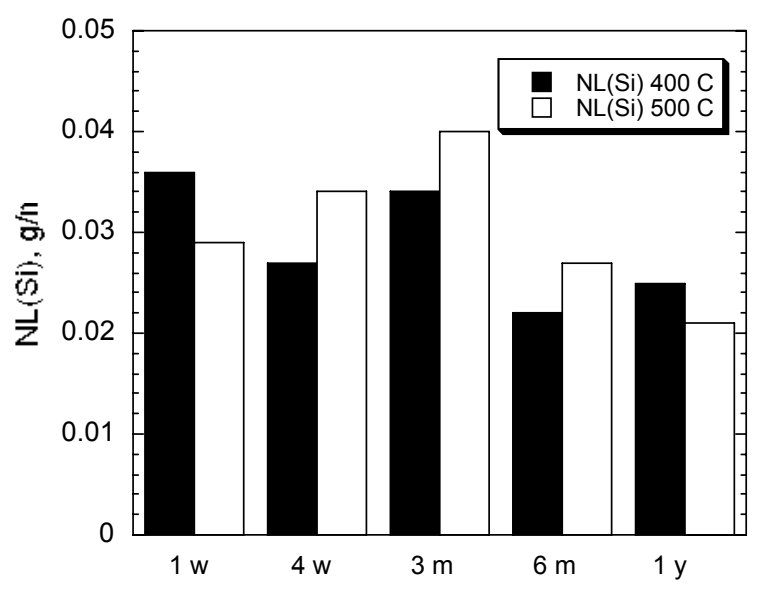

(d)

Fig. 17. Results of 7-day PCT with long-term heat-treated CWF materials: (a) $\mathrm{Cl}^{-}$in RWS, (b) $N L(\mathrm{~B}),(\mathrm{c}) N L(\mathrm{Na})$, and (d) $N L(\mathrm{Si})$. 


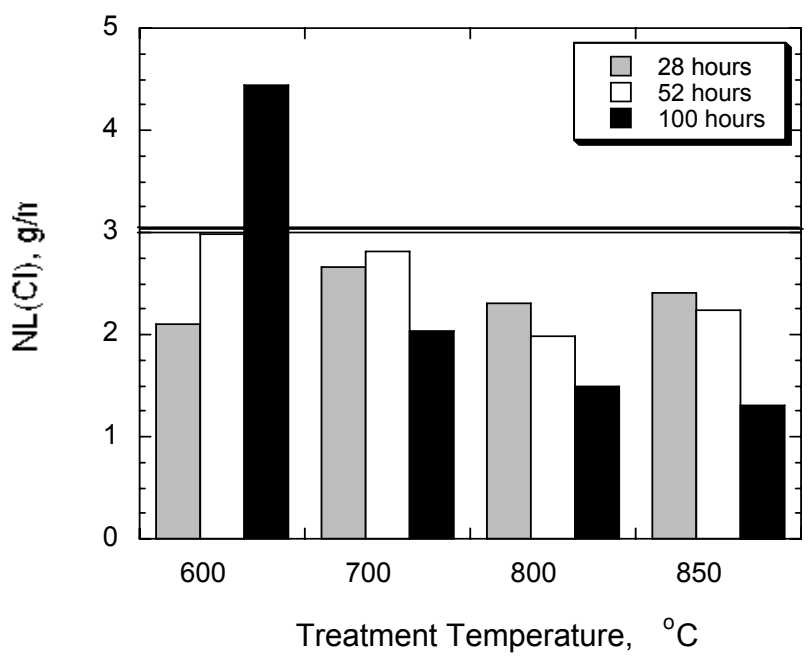

(a)

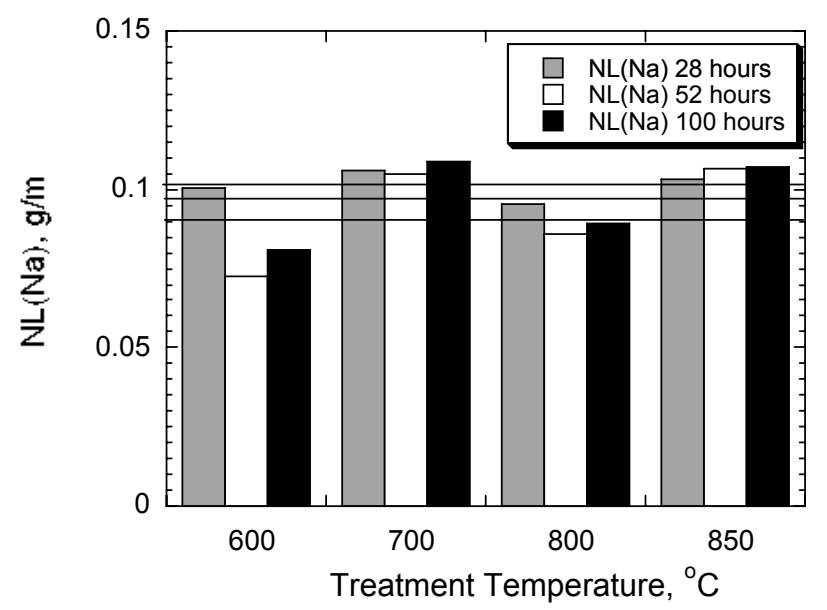

(c)

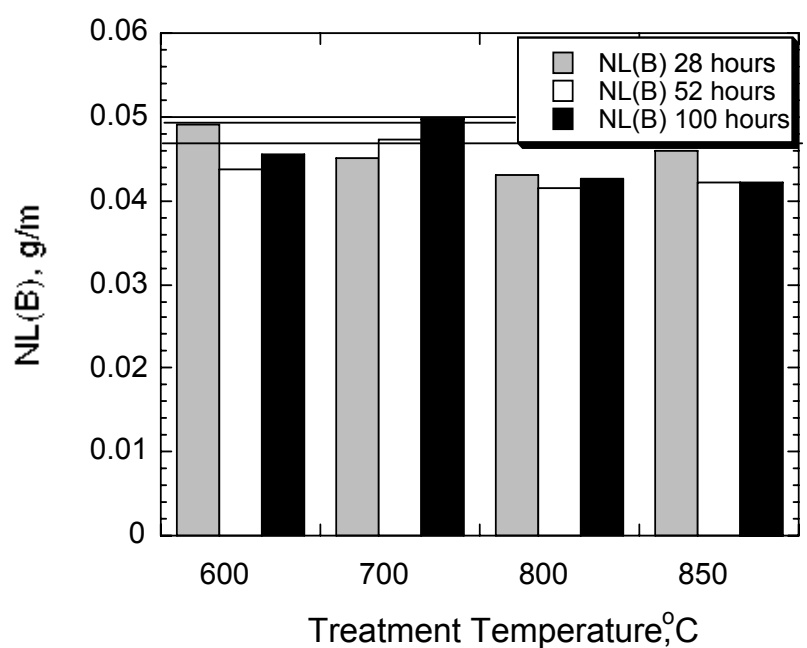

(b)

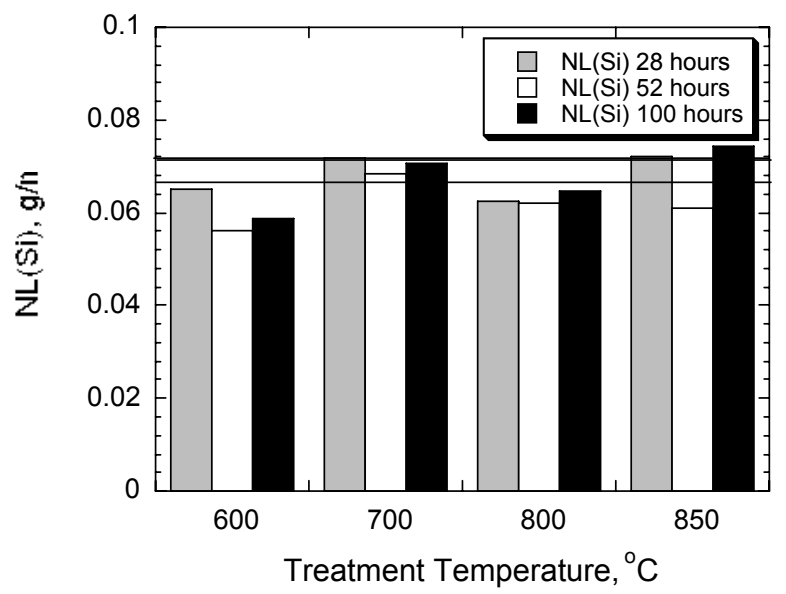

(d)

Fig. 18. Results of 7-day PCT with short-term heat-treated CWF materials: (a) $\mathrm{Cl}^{-}$in RWS, (b) $N L(\mathrm{~B}),(\mathrm{c}) N L(\mathrm{Na})$, and (d) $N L(\mathrm{Si})$. Horizontal lines give results for triplicate tests with CWF material PC10402 without heat treatment. 


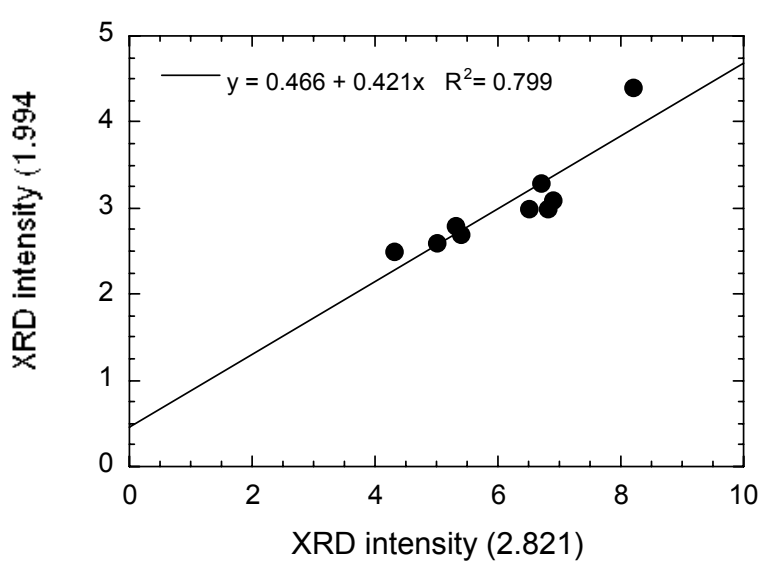

(a)

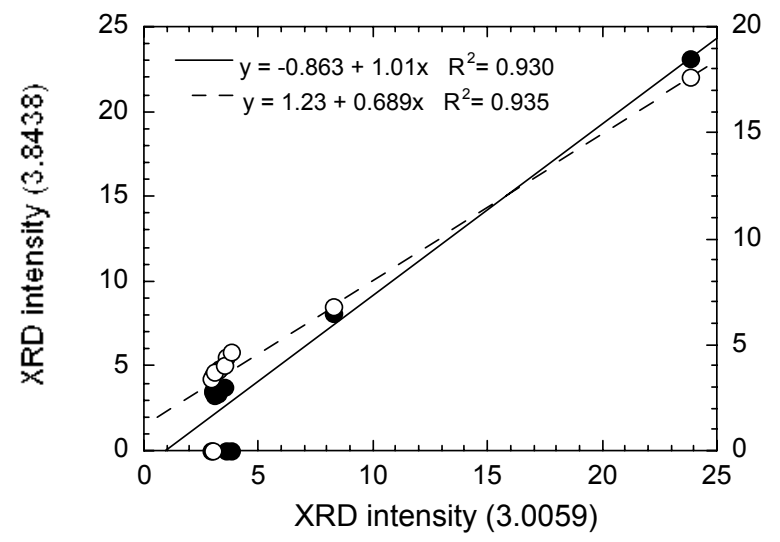

(c)

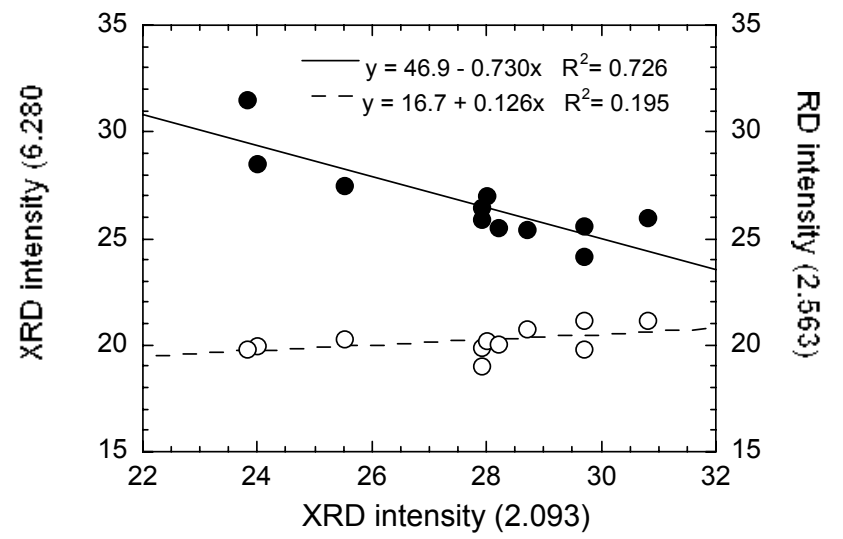

(e)

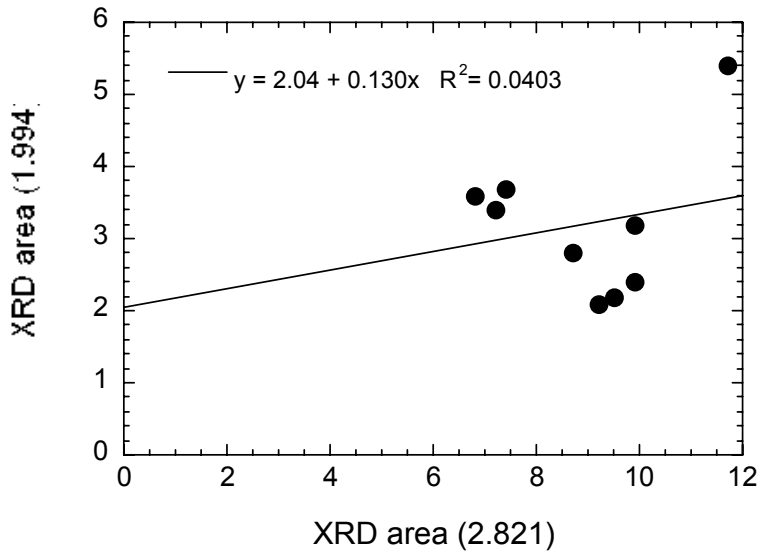

(b)

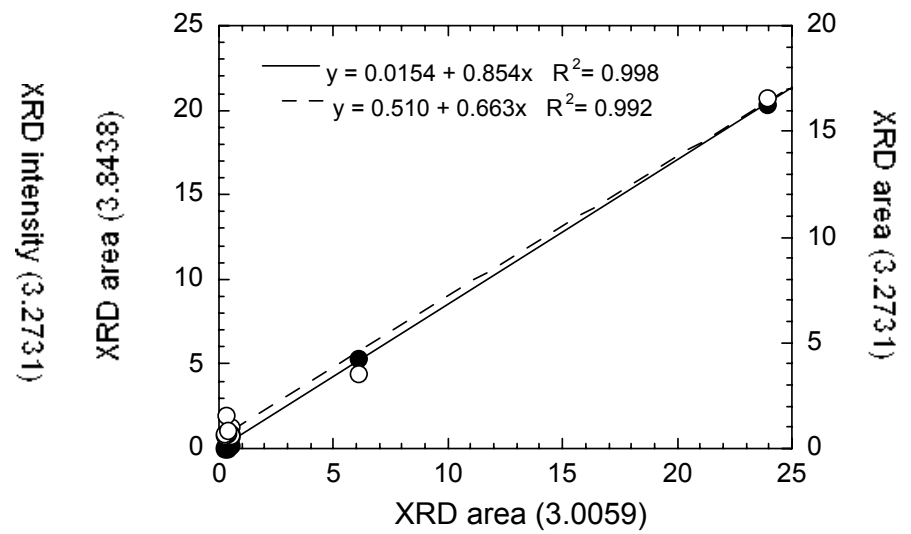

(d)

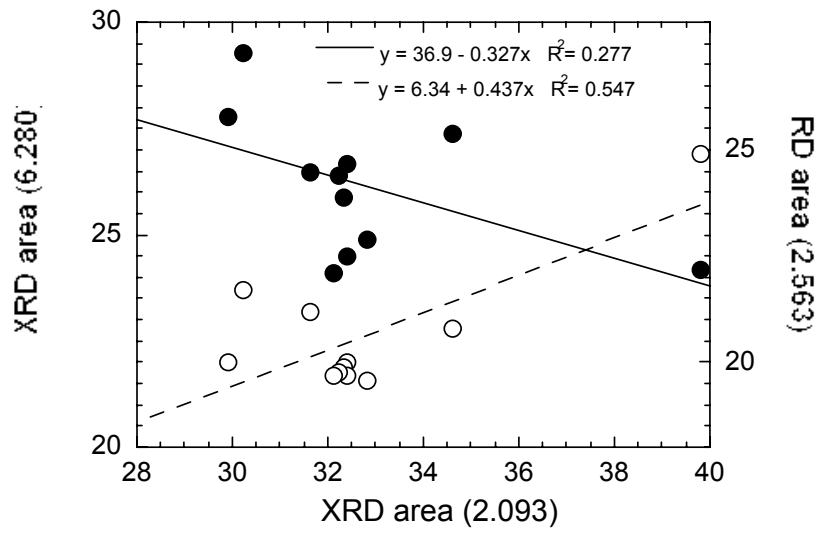

(f)

Fig. 19. Correlations in XRD spectra of salt-loaded CWF materials between (a) heights and (b) area\% in halite peaks at 1.994 and $2.821 \AA$; (c) heights and (d) area\% in nepheline peaks at $3.0059,3.8438,3.2731$, and $2.821 \AA$; and (e) heights and (f) area\% in sodalite peaks at 2.093, 2.563, and $6.280 \AA$. Filled symbols and solid lines refer to the left-hand axis, and open symbols and dashed lines refer to the right-hand axis. 


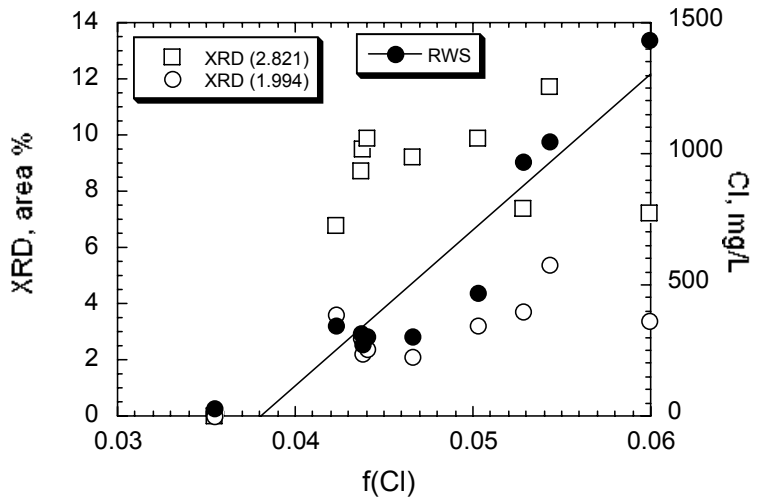

(a)

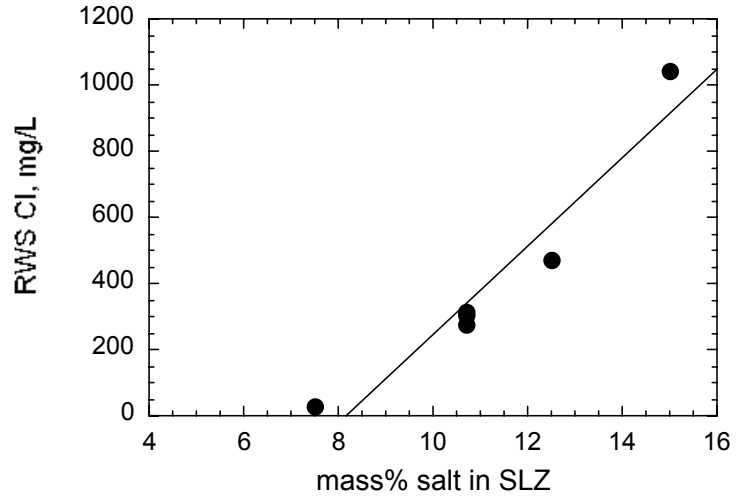

(b)

Fig. 20. (a) Comparison of $\mathrm{Cl}$ concentrations in (•) RWS tests (right ordinate) and halite XRD peaks at $(\square) 2.821 \AA$ and $(\bigcirc) 1.994 \AA$ (left ordinate) with measured $\mathrm{Cl}$ content in salt-loaded CWF products. (b) Comparison of $\mathrm{Cl}$ concentrations in RWS tests with mass\% salt in SLZ used to make salt-loaded CWF products. 


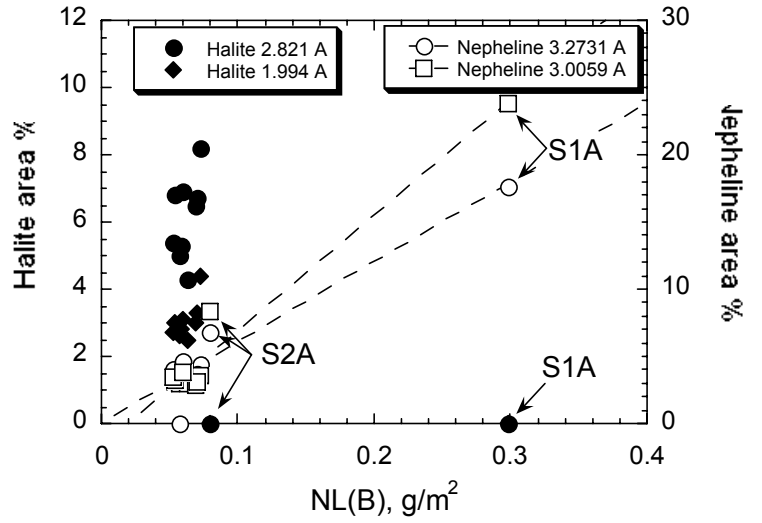

(a)

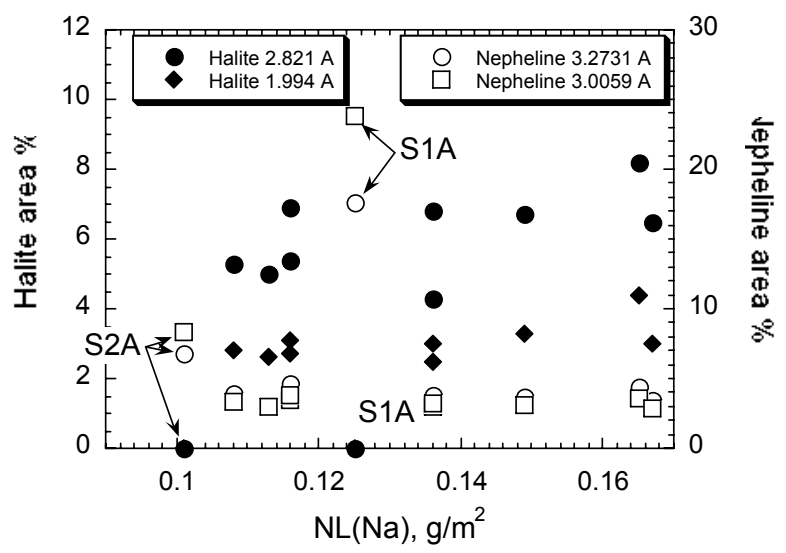

(c)

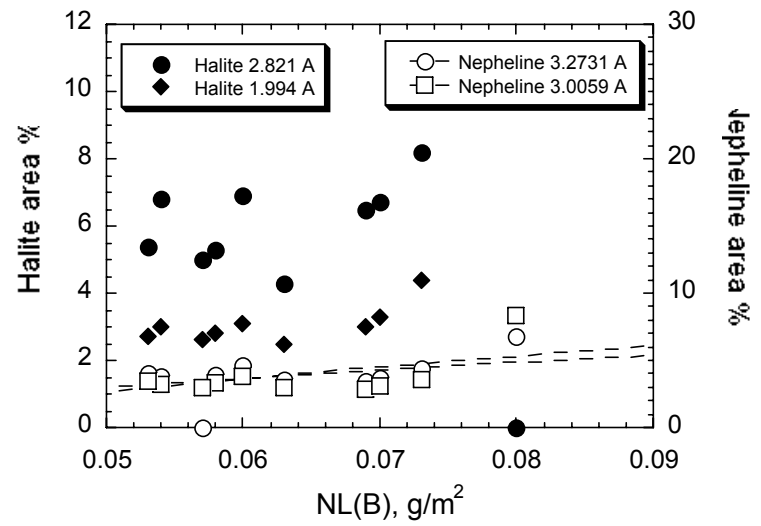

(b)

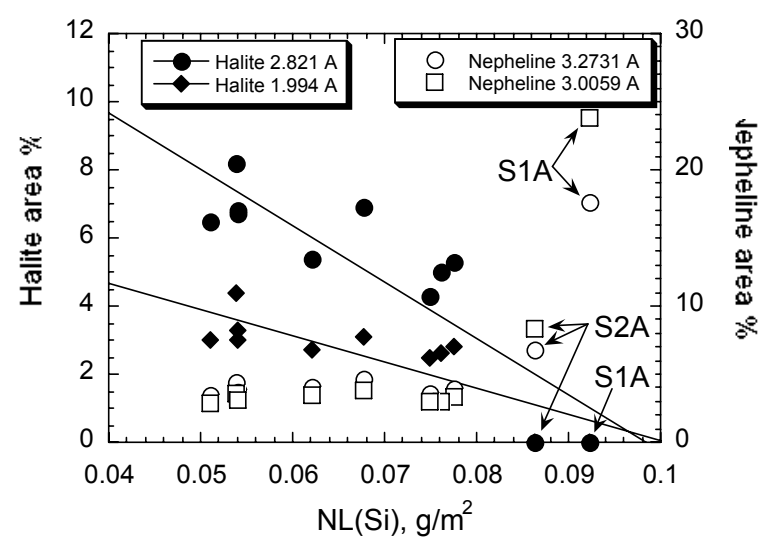

(d)

Fig. 21. Correlation between amounts of halite and nepheline in salt-loaded CWF products and durability in 7-day PCTs: (a) and (b) based on $N L(\mathrm{~B})$, (c) based on $N L(\mathrm{Si})$, and (d) based on $N L(\mathrm{Na})$. Dashed lines show regressions with nepheline peaks, and solid lines show regressions with halite peaks. 


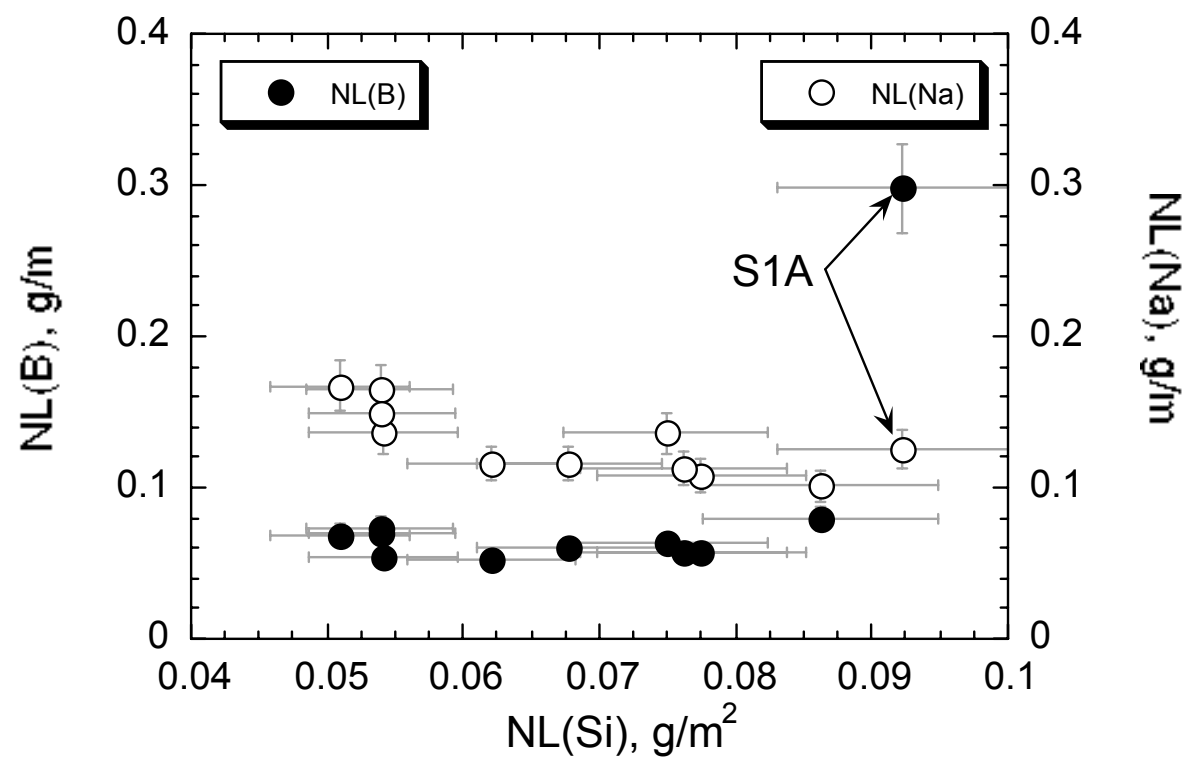

Fig. 22. Correlation of $(\bullet) N L(\mathrm{~B})$ and $(\mathrm{O}) N L(\mathrm{Na})$ with $N L(\mathrm{Si})$ for $7-$ day PCTs with salt-loaded CWF materials. 


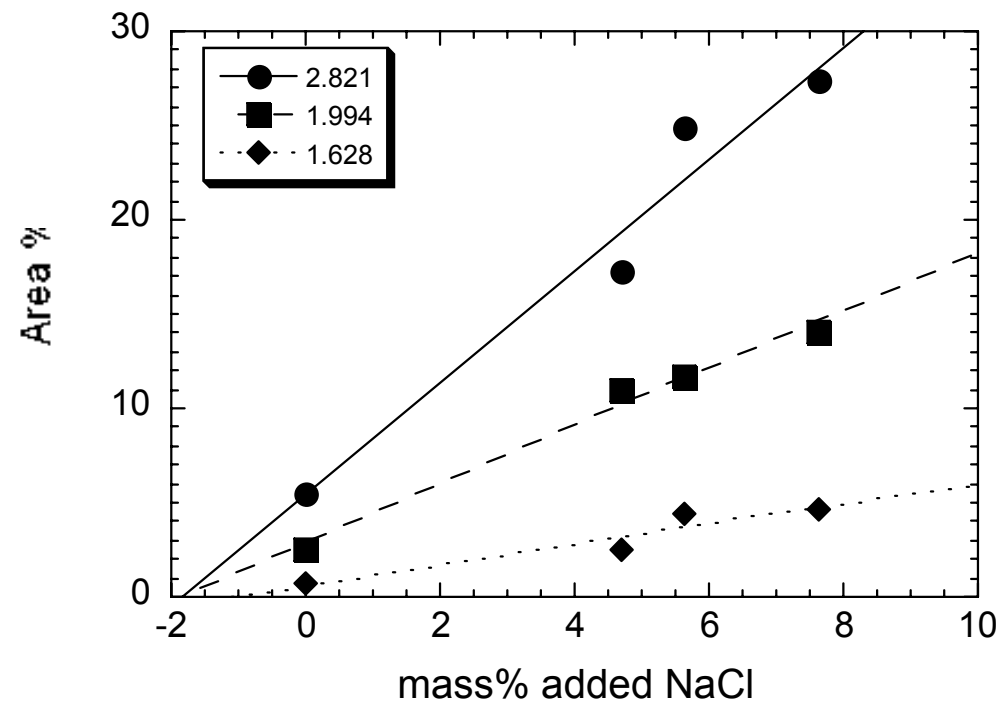

Fig. 23. XRD peak area\% values for CWF material PC10402 with added $\mathrm{NaCl}$.

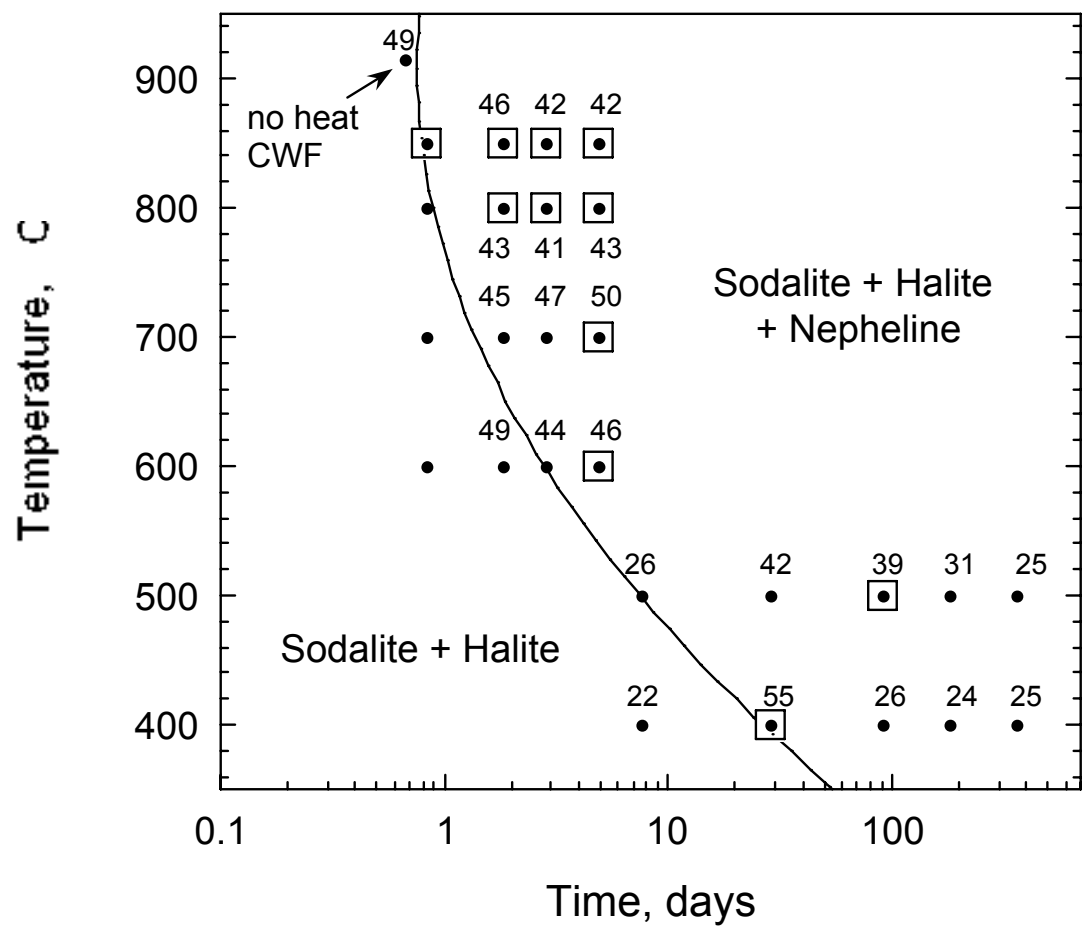

Fig. 24. Time-temperature-transformation plot for heat-treated CWF products. Temperature-time conditions that were evaluated are indicated (•). Halite was detected in all samples, and at least 1 nepheline peak was detected in samples shown in squares. Numbers on plot give $N L(\mathrm{~B})$ values for 7-day PCTs, in $\mathrm{mg} / \mathrm{m}^{2}$. The line shows the empirical TTT curve for nepheline formation. 


\section{REFERENCES}

Andrews, M.K., and Bibler, N.E. 1993. "Radioactive Demonstration of DWPF Product Control Strategy," Ceramic Transactions 39, Environmental and Waste Management Issues in the Ceramic Industry, 205-221.

ASTM. 2004. Standard Test Methods for Determining Chemical Durability of Nuclear Waste Glasses: The Product Consistency Test (PCT) Standard C1285-02, Annual Book of ASTM Standards Vol. 12.01, American Society for Testing and Materials, West Conshohocken, PA.

DOE (U.S. Department of Energy). 2002. Waste Acceptance System Requirements Document, Rev. 4. U.S. Department of Energy, Office of Civilian Radioactive Waste Management Report DOE/RW-0351, Rev. 04. January 2002.

Ebert, W.L., Lewis, M.A., and Johnson, S.G. 2002a. "Application of the PCT to the EBR II Ceramic Waste Form," Proceedings of the DOE Spent Nuclear Fuel and Fissile Materials Management Meeting, Charleston, SC, September 17-20, 2002.

Ebert, W.L., Lewis, M.A., and Johnson, S.G. 2002b. "The Precision of Product Consistency Tests Conducted with a Glass-Bonded Ceramic Waste Form." Journal of Nuclear Materials 305:37-51.

Ebert, W.L., and Wolf, S.F. 2000. "An Interlaboratory Study of a Standard Glass for Acceptance Testing of Low-Activity Waste Glass." Journal of Nuclear Materials 282:112-124.

Ebert, W.L., Buck, E.C., Luo, J.S., Tam, S.-W., and Bates, J.K. 1998. Corrosion Behavior of Environmental Assessment Glass in Product Consistency Tests of Extended Duration. Argonne National Laboratory Report ANL-98/27.

Fanning, T.H., Ebert, W.L., Frank, S.M., Hash, M.C., Morris, E.E., Morss, L.R., O'Holleran, T.P., and Wigeland, R.A. 2003. Status of Ceramic Waste Form Degradation and Radionuclide Release Modeling, Argonne National Laboratory Report ANL-03/8.

Federal Register. 2000. Record of Decision for the Treatment and Management of SodiumBonded Spent Nuclear Fuel, Vol. 65, No. 182, pp. 56565-56570 (September 19, 2000).

Frank, S.M. 2004. "Product Consistency Test and Density Measurement Results from Surrogate CWF Inter-Granular Glass Material." ANL-W interlaboratory memo ENT-MS-(SMF)-04-005, August 26, 2004.

Goff, K.M., Ackerman, J.P., Simpson, M.F., Hash, M.C., Bateman, K.J., Battisti, T.J., Hirsche, K.L., and Kennedy, J.R. 1999. Ceramic Waste Form Process Qualification Plan. Argonne National Laboratory Report ANL-NT-118.

Jeong, S-Y., Fanning, T.H., Morss, L.R., and Ebert, W.L. 2002. Corrosion Tests to Determine Temperature and $\mathrm{pH}$ Dependencies of the Dissolution Rates of Sodalite, Binder Glass, and Ceramic Waste Form. Argonne National Laboratory Report ANL-02/32. 
Lewis, M.A., Hash, M.C., Hebden, A.S., and Ebert, W.L. 2002. Tests with Ceramic Waste Form Materials Made by Pressureless Consolidation. Argonne National Laboratory Report ANL$02 / 10$.

Li, H., Vienna, J.D., Hrma, P., Smith, D.E., and Schweiger, M.J. 1997. "Nepheline Precipitation in High-Level Waste Glass: Composition Effects and Impact on Waste Form Acceptability." Scientific Basis for Nuclear Waste Management XX, Materials Research Society Symposium Proceedings 465, pp. 261-268. Materials Research Society, Pittsburgh, PA.

Morss, L.R., Johnson, S.G., Ebert, W.L., DiSanto, T., Frank, S.M., Holly, J.L., Kropf, J.A., Mertz, C.J., Noy, M., O’Holleran, T.P., Richmann, M.K., Sinkler, W., Tsai, Y., and Warren, A.R. 2002. Corrosion Tests with Uranium- and Plutonium-Loaded Ceramic Waste Forms. Argonne National Laboratory Report ANL-02/9.

Olson, K.M., Smith, G.L., and Marschman, S.C. 1995. Product Consistency Testing of Three Reference Glasses in Stainless Steel and Perfluoroalkoxy Resin Vessels, Pacific Northwest Laboratory report PNL-10497. 


\section{APPENDIX A. PREPARATION OF CWF PRODUCTS}

This appendix provides details and commentary regarding preparation of the CWF materials that were used to measure the effects of salt loading and glass loading. The term "CWF material" is used to indicate a particular mixture and composition, and the term "CWF product" is used to identify a particular specimen made for testing. 
SLZ/Glass Batch S1/1:

\section{PC CWF Material S1}

Zeolite: 641.25 grams from batch MPE-1; bottle \#1

Salt: 33.75 grams

Glass: 225 grams

Salt occlusion: V-mixer program 1, held for 18 hours at a nominal temperature of $500{ }^{\circ} \mathrm{C}$, beginning May 25, 2004. Occluded salt was lumpy, with free chloride analyses of $0.042 \pm 0.004$, $0.32 \pm 0.03$, and $0.13 \pm 0.01$ mass $\%$.

Glass mixing: 18 hours rotating at $\sim 30 \mathrm{rpm}$ in V-mixer at room temperature, June 15, 2004.

Salt-Loaded CWF Products: PC CWF product S1A was made by consolidating $400 \mathrm{~g}$ of powder, starting June 16, 2004. It has numerous powdery white inclusions, each surrounded by material with a slightly different color and texture than areas farther away from the inclusions (see Fig. A.1a). Analyses of grains within inclusions (see Fig. A.1b) with SEM/EDS give Al/Si ratios consistent with the SLZ and sodalite compositions. This suggests that the powdery white material is either partially occluded zeolite that did not transform to sodalite or sodalite that was not encapsulated by the binder glass.

The approximately 500 grams of powder left over from consolidation of CWF product S1A were returned to the argon glovebox and kept there until November 2004. On November 11, this material was sieved in air with a 300- $\mu \mathrm{m}$ sieve; approximately $6 \mathrm{~g}$ of the material did not pass through the sieve. Powder XRD patterns of the material that was removed are consistent with a mixture of partially salt-occluded zeolite and a material with a halite-type cubic structure.

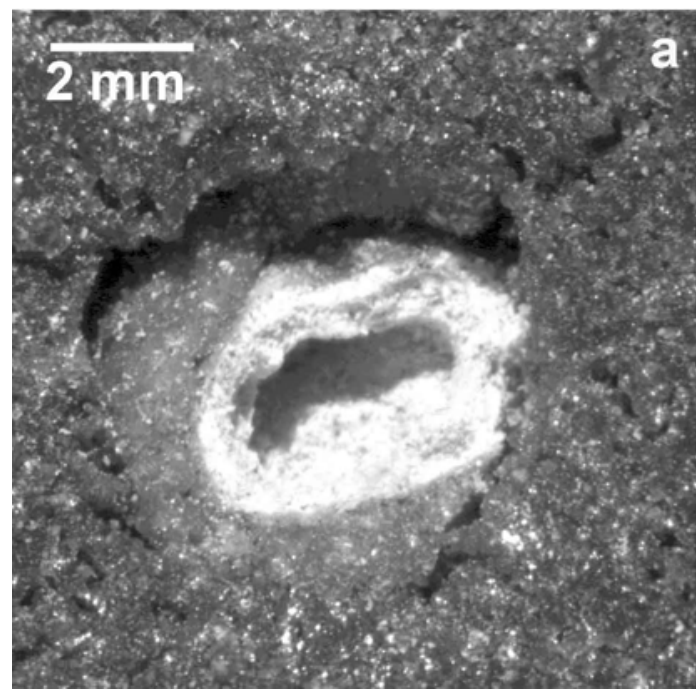

(a)

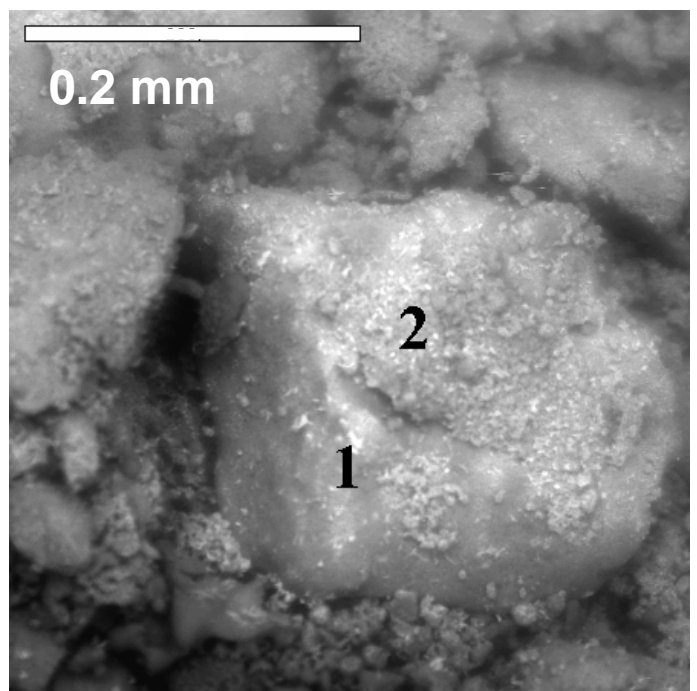

(b)

Fig. A.1. PC CWF product S1A has a glassy texture and a uniform dark gray color with several inclusions. (a) Typical inclusion with hollow center and cracks separating the included material from the adjacent product. (b) High-magnification image of large grain within an inclusion (numbers locate sites of EDS analyses). 
PC CWF product S1B (see Fig. A.2) was consolidated on November 12, 2004, using 405.45 grams of the powder that had passed through the sieve. The waste form made audible crackling noises when unmolded, and small fragments popped into the air.
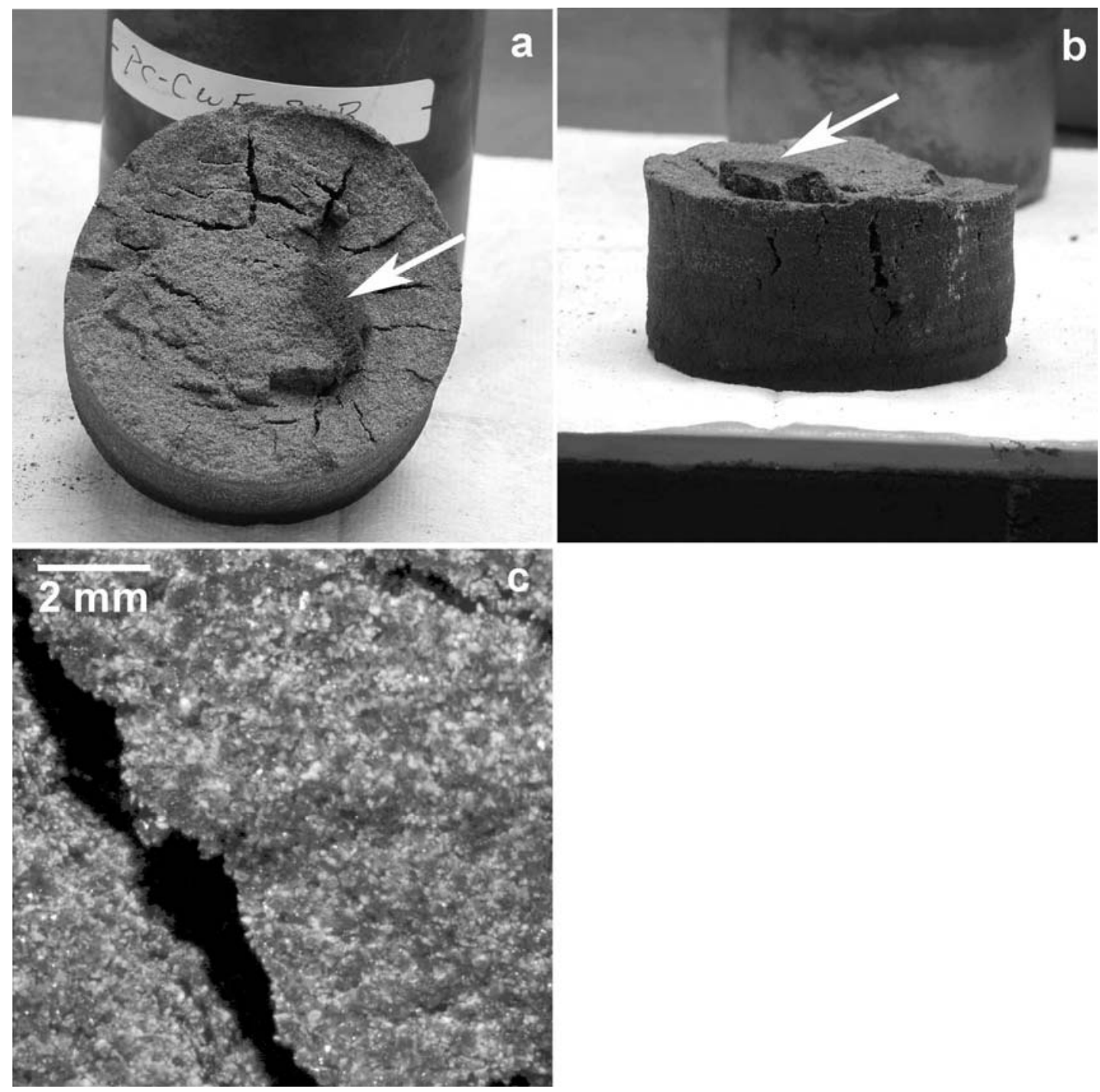

Fig. A.2. PC CWF product S1B consists of granular gray material with numerous deep fissures but without visible inclusions. The raised dark area indicated by the arrow in photos (a) and (b) is the top surface of the waste form that was beneath the steel disk placed on top of the powder before consolidation. 


\section{PC CWF Material S2}

SLZ/Glass Batch S2/2:

Zeolite: 624.38 grams from batch MPE-1 ( 30 grams from bottle \#4; remainder from \#5) Salt: 50.65 grams

Glass: 225.02 grams

Salt occlusion: V-mixer program 2, November 16-17, 2004 (3 minutes cold mixing, 24 hours with furnace, 4.5 hours rotation during cooling, rotation turned off with temperature at $\sim 250{ }^{\circ} \mathrm{C}$. Furnace and rotation were accidentally turned off for $\sim 10$ minutes, during which time the temperature decreased to $470{ }^{\circ} \mathrm{C}$. It then ramped back to $525{ }^{\circ} \mathrm{C}$, resulting in a total time of $\sim 0.75$ hour during which the temperature was below the nominal maximum.) Free-chloride analyses were $0.02 \pm 0.002,0.03 \pm 0.003$, and $0.03 \pm 0.003$ mass $\%$.

Glass mixing: 5 hours and 10 minutes.

Salt-Loaded CWF Product: PC CWF product S2C (Fig. A.3) was consolidated from $409.17 \mathrm{~g}$ of powder, starting November 22, 2004.

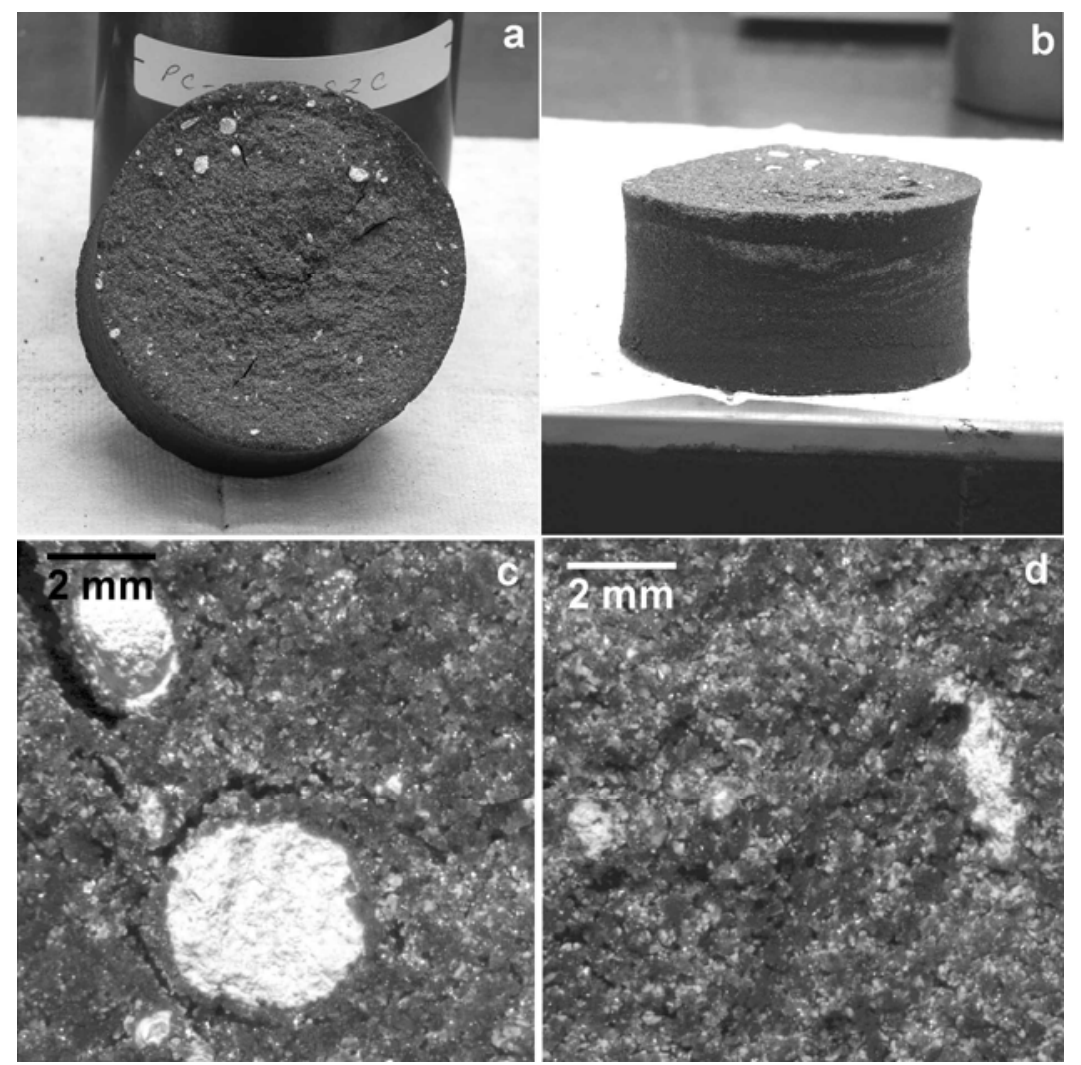

Fig. A.3. (a) PC CWF product S2C consists of granular gray material with numerous white, powdery inclusions. As shown in photo (b), the sides of the waste form are strongly bowed inwards and show a wavy layered structure. Most inclusions exposed at the broken surfaces of the waste form generally do not appear hollow or show a macroscopically visible layered structure. 


\section{PC CWF Material S3}

\section{SLZ/Glass Batch S3/1}

Zeolite: 602.78 grams from batch MPE-1; 584.42 g were from bottle \#3; remainder was from bottle \#4

Salt: 72.22 grams

Glass: 225.01 grams

Salt occlusion: Laboratory-scale V-mixer program 1, October 20-21, 2004. Total furnace time: 22 hours and 40 minutes; mixed 24 hours and 20 minutes during and after cooling. Occluded salt was lumpy, with free-chloride analyses of $0.19 \pm 0.01,0.42 \pm 0.02$, and $0.47 \pm 0.02 \mathrm{mass} \%$.

Glass mixing: 20 hours on November 2-3, 2004. The occluded zeolite was left in V-mixer in Ar atmosphere between salt occlusion and glass mixing.

Salt-Loaded CWF Products: PC CWF product S3A (Fig. A.4) was consolidated from $401.2 \mathrm{~g}$ powder, starting November 8, 2004. Approximately 500 grams of remaining powder was sieved in air with a 50 mesh sieve $(0.3 \mathrm{~mm})$; approximately 7.1 grams of material did not pass through the sieve and was discarded. PC CWF product S3B (Fig. A.5) was consolidated starting November 10, 2004, using $401.39 \mathrm{~g}$ of the powder that had passed through the sieve.

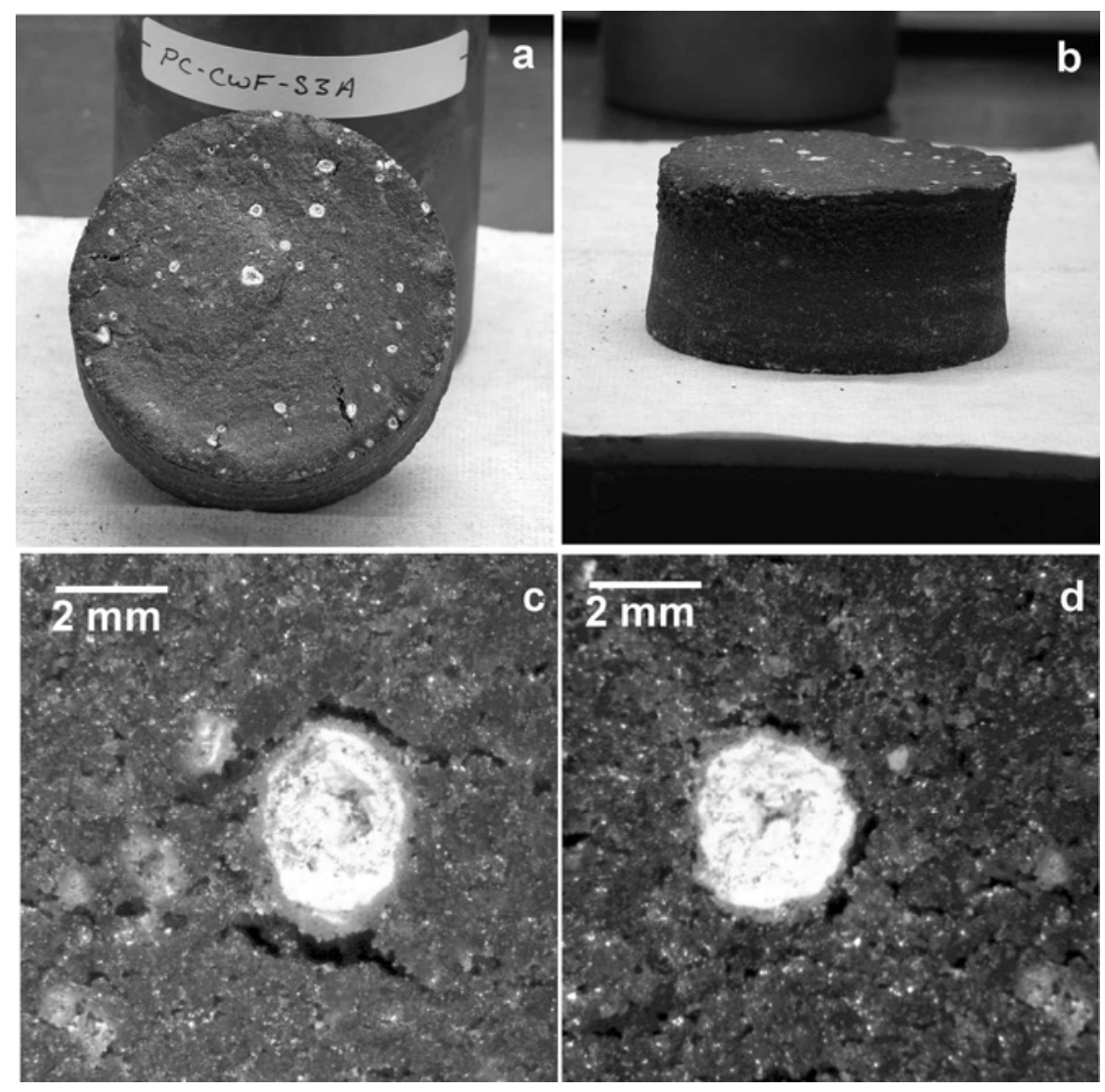

Fig. A.4. PC CWF product S3A is dark gray and glassy with numerous hollow inclusions of white, powdery material and a few small fissures. 


\section{PC CWF Material S3 (continued)}

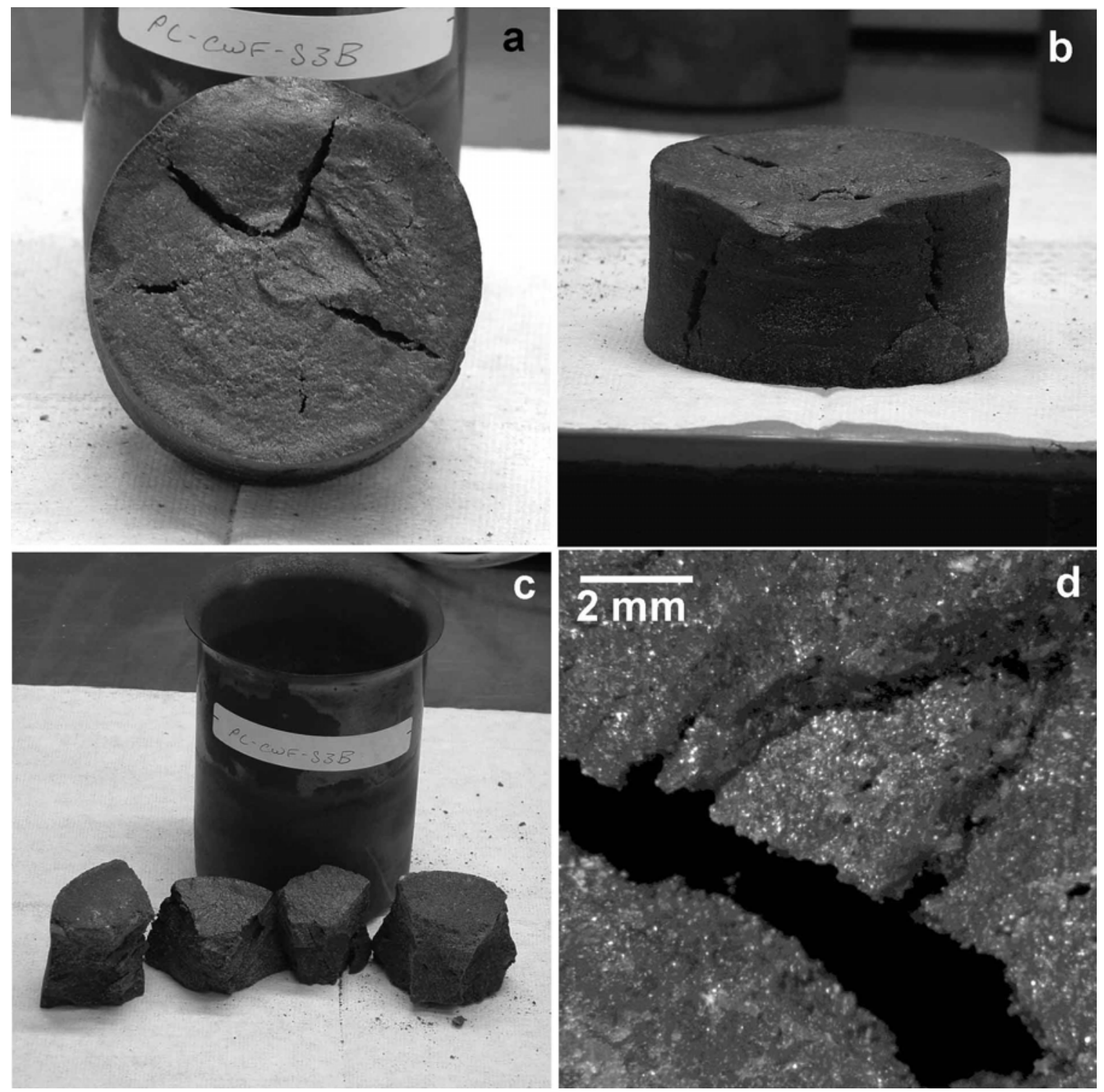

Fig. A.5. PC CWF product S3B is dark gray and glassy, with several fissures extending through the entire depth. No powdery white inclusions are visible. 


\section{PC CWF Material S3 (continued)}

\section{SLZ/Glass Batch S3/2:}

Zeolite: 602.79 grams from batch MPE-1, bottle \#4

Salt: 72.19 grams

Glass: 224.99 grams

Salt occlusion: V-mixer program 2, mixed November 11-12, 2004 ( 17.5 hours while heating and 6.5 hours while cooling with rotation. Rotation stopped when temperature was still $190{ }^{\circ} \mathrm{C}$. The occluded salt had a few soft lumps. Results of free-chloride analyses: $0.040 \pm 0.004,0.061$ \pm 0.006 , and $0.065 \pm 0.007$ mass $\%$.

Glass mixing: 18.5 hours at room temperature.

Salt-Loaded CWF Product: PC CWF product S3C (Fig. A.6) was consolidated starting November 16, 2004. The remaining SLZ and glass mixture was passed through a 300 mesh screen; $4.2 \mathrm{~g}$ of material did not pass through the sieve and was discarded.

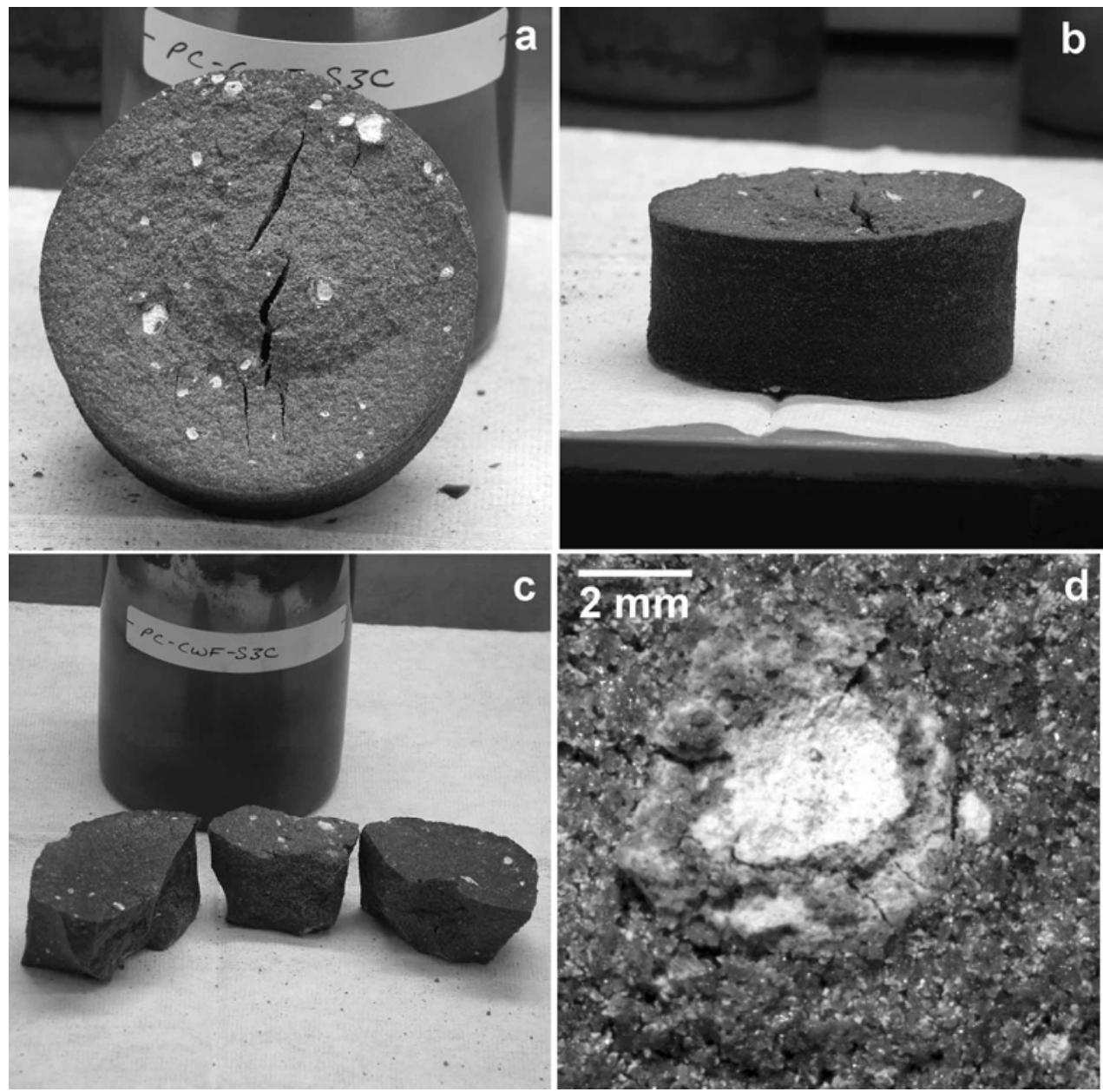

Fig. A.6. $\mathrm{PC}$ CWF product $\mathrm{S} 3 \mathrm{C}$ is lighter gray than product $\mathrm{S} 2 \mathrm{~A}$ and has a more granular (less glassy) texture. It has numerous large powdery white inclusions. 


\section{PC CWF Material S3 (continued)}

\section{SLZ/Glass Batch S3/3:}

Zeolite: 602.77 grams from batch MPE070904; bottle \#5

Salt: 72.22 grams

Glass: 225.43 grams

Salt occlusion: V-mixer program 2, dates December 15-16, 2004 ( 22.5 hours while heating and 4.5 hours while cooling with rotation. Rotation stopped when temperature was still $251{ }^{\circ} \mathrm{C}$. Freechloride analyses: $0.031 \pm 0.003,0.045 \pm 0.005$, and $0.068 \pm 0.007$ mass $\%$.

Glass mixing: 4 hours at room temperature.

Salt-Loaded CWF Product: PC CWF product S3E (Fig. A.7) was consolidated from $400.2 \mathrm{~g}$ powder starting December 20, 2004.

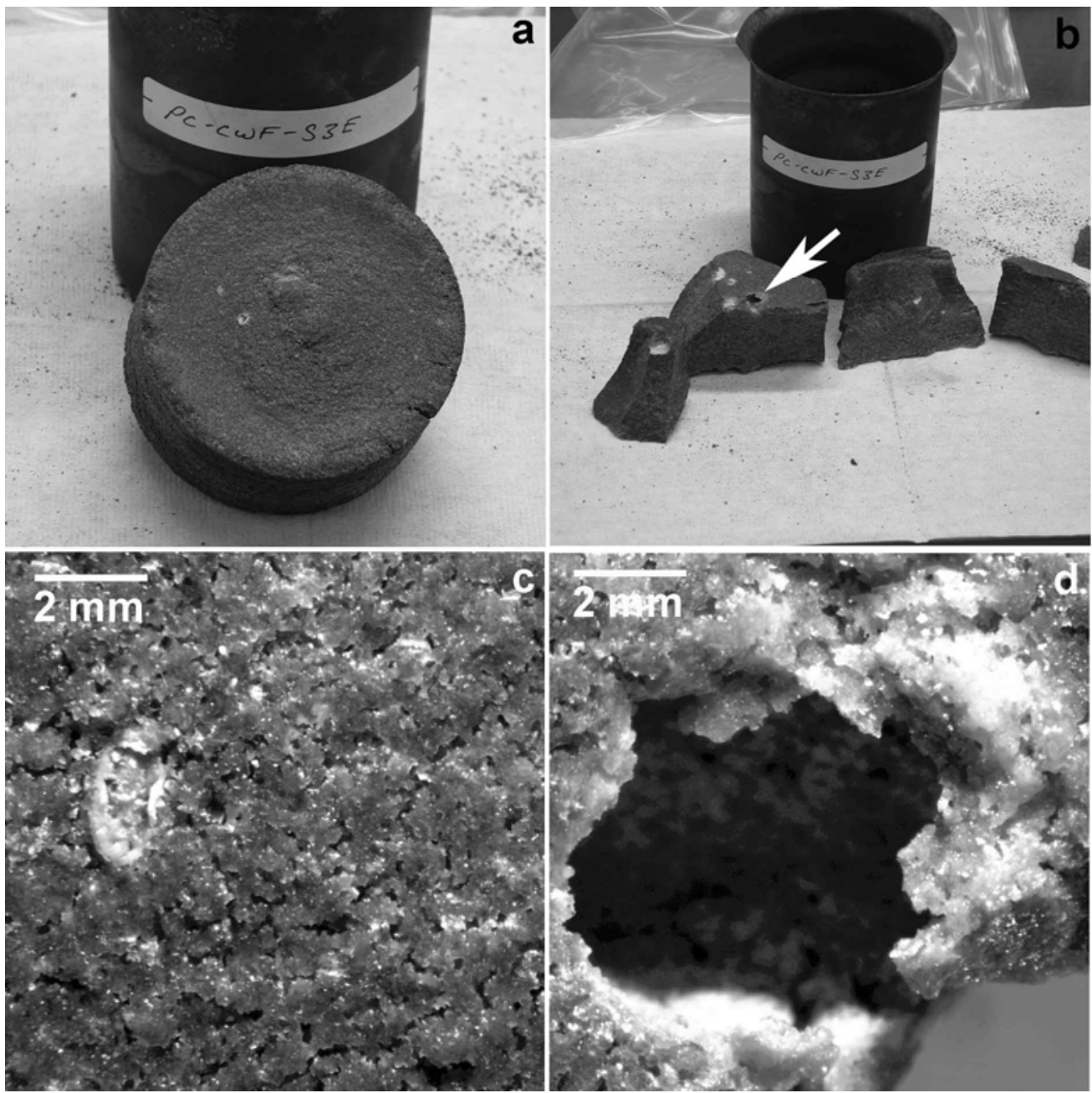

Fig. A.7. PC CWF product S3E has a glassy texture and a uniform dark gray color. It has a few powdery white inclusions. The arrow in (b) locates the pit seen in (d). 


\section{PC CWF Material S4}

SLZ/Glass Batch S4/1:

Zeolite: 590.62 grams from batch MPE-1 (bottle \#6)

Salt: 84.36 grams

Glass: 225.04 grams

Salt occlusion: V-mixer program 2, dates November 22-23, 2004 (a few minutes cold mixing, 23.5 hours with furnace, 5 hours rotation during cooling, rotation turned off with temperature at $\sim 256{ }^{\circ} \mathrm{C}$.) Results of 3 free-chloride analyses: $0.02 \pm 0.003,0.015 \pm 0.002$, and $0.06 \pm 0.009$ $\operatorname{mass} \%$.

Glass mixing: 4 hours at room temperature.

Salt-Loaded CWF Product: PC CWF product S4A (Fig. A.8) was consolidated from 401.55 g powder. Powder was measured into beaker with steel disk and plug on November 29, 2004, and then left in furnace overnight at ambient temperature with an Ar flow of $\sim 2$ standard cubic feet per hour before the furnace was started on November 30, 2004.

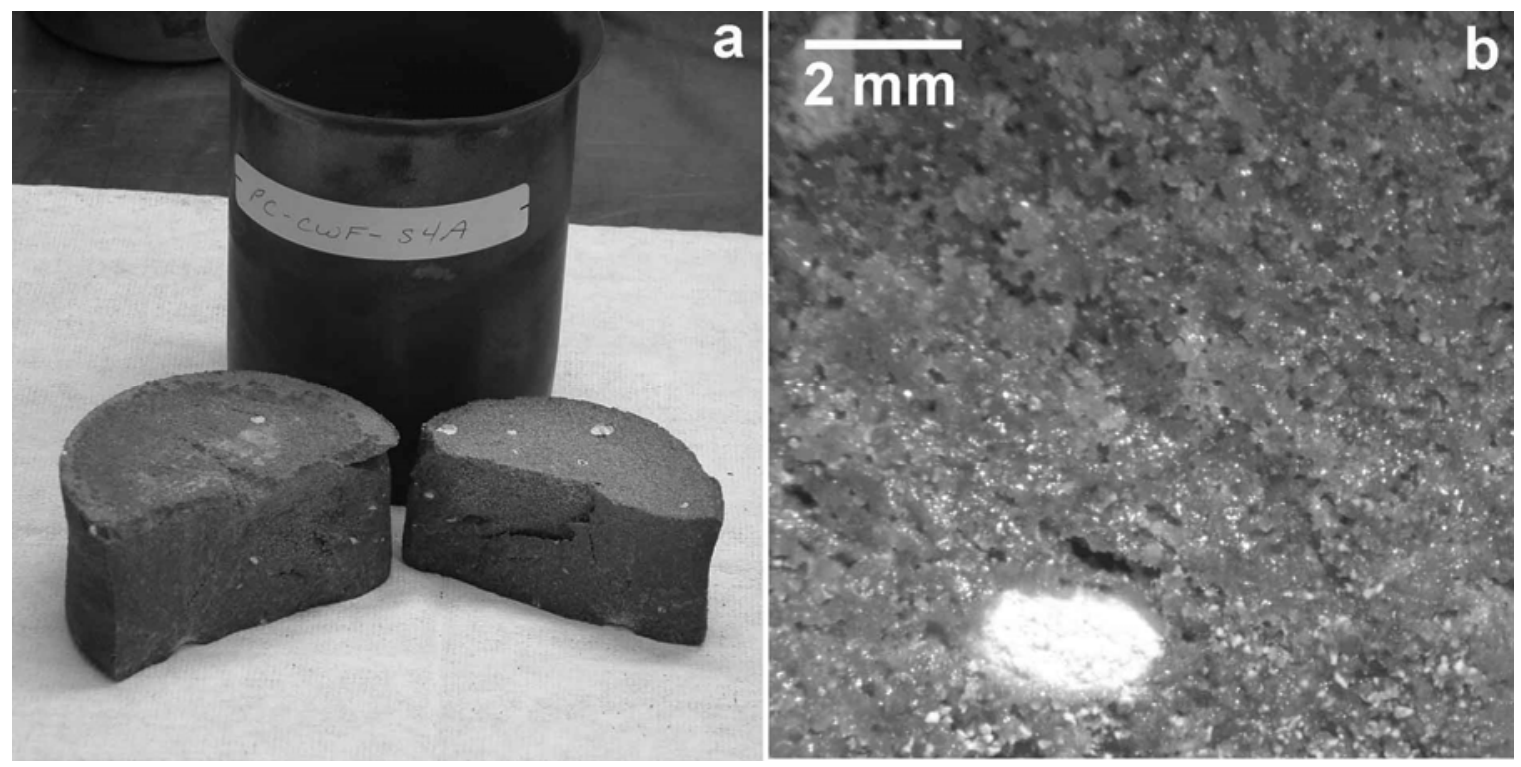

Fig. A.8. PC CWF product S4A. 


\section{PC CWF Material S5}

SLZ/Glass Batch S5/1:

Zeolite: 573.75 grams from batch MPE-1 (146.64 g from bottles \#5 and \#6; remainder from bottle \#7)

Salt: 101.25 grams

Glass: 225.00 grams

Salt occlusion: V-mixer program 2, dates November 29-30, 2004 (a few minutes cold mixing, $\sim 25.5$ hours with furnace, 3.25 hours rotation during cooling, rotation turned off with temperature at $\sim 306{ }^{\circ} \mathrm{C}$.) Results of 3 free-chloride analyses: $0.026 \pm 0.001,0.053 \pm 0.003$, and $0.22 \pm 0.01 \operatorname{mass} \%$.

Glass mixing: 4 hours at room temperature.

Salt-Loaded CWF Product: PC CWF product S5B (Fig. A.9) was made by consolidating of $403.97 \mathrm{~g}$ powder beginning December 7,2004 . The furnace temperature was $\sim 140{ }^{\circ} \mathrm{C}$ when sample was loaded.

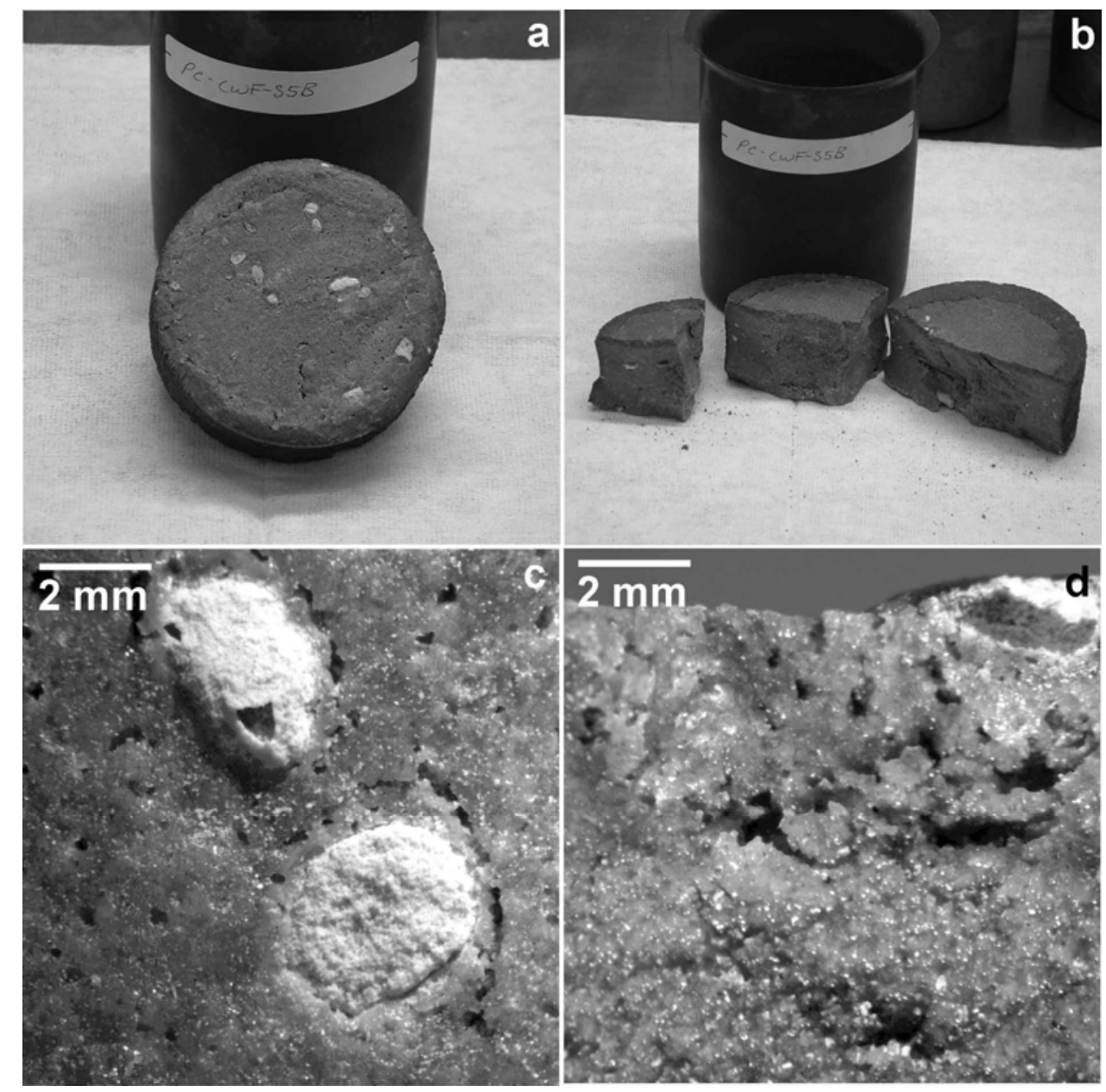

Fig. A.9. PC CWF product S5B contains a few large inclusions and many small inclusions. 


\section{PC CWF Material G1}

\section{SLZ/Glass Batch G1/1:}

Zeolite: 642.98 grams from batch MPE-1 (278 g from bottle \#7; remainder from bottle \#1) Salt: 77.05 grams, including some lumps that are a few mm across Glass: 180.16 grams

Salt occlusion: V-mixer program 2, dates December 2-3, 2004 (a few minutes cold mixing, 23 hours 20 minutes with furnace, 2 hours 50 minutes rotation during cooling, rotation turned off with temperature at $\sim 330{ }^{\circ} \mathrm{C}$.) Results of 3 free-chloride analyses: $0.04 \pm 0.002,0.14 \pm 0.01$, and $0.15 \pm 0.01$ mass $\%$.

Glass mixing: 3.5 hours at room temperature in air atmosphere (vacuum pump problems).

Salt-Loaded CWF Product: PC CWF product G1A (Fig. A.10) was made by consolidating 400.1 g powder beginning December 9, 2004.

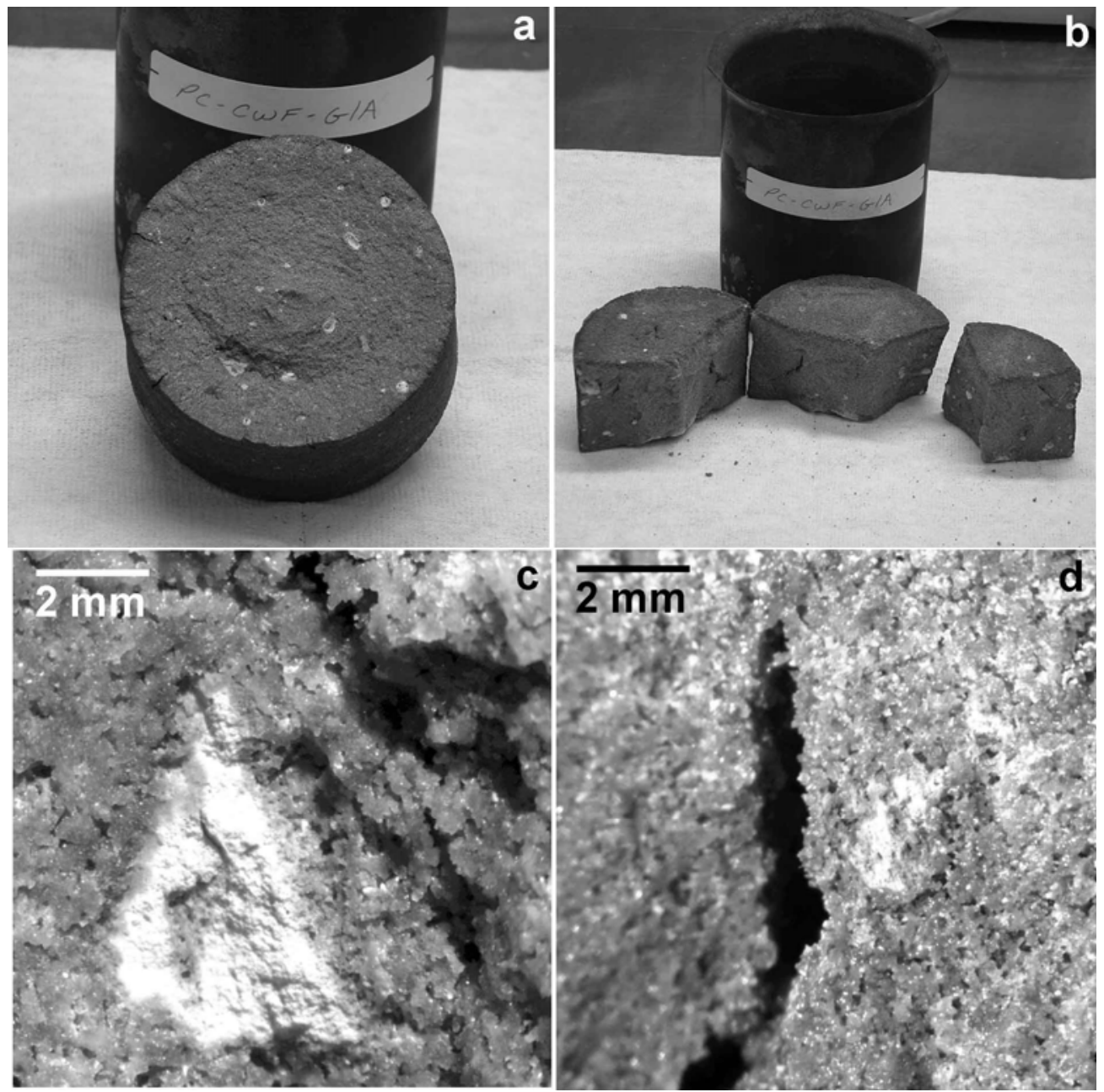

Fig. A.10. PC CWF product G1A is pale gray and glassy, with numerous small open pores. Inclusions are powdery and pale gray, and do not appear to be hollow. 


\section{PC CWF Material G2}

SLZ/Glass Batch G2/1:

Zeolite: 622.87 grams from batch MPE-1 (297.22 g from bottle \#1; remainder from bottle \#9)

Salt: 74.63 grams, including some lumps that were a few $\mathrm{mm}$ across

Glass: 202.71 grams

Salt occlusion: V-mixer program 2, dates December 9-10, 2004 (a few minutes cold mixing, $\sim 21$ hours 40 minutes with furnace, 3.5 hours rotation during cooling, rotation turned off with temperature at $276{ }^{\circ} \mathrm{C}$.) Results of 3 free-chloride analyses: $0.056 \pm 0.002,0.12 \pm 0.01$, and 0.15 \pm 0.01 mass $\%$.

Glass mixing: 3.25 hours at room temperature.

Salt-Loaded CWF Product: PC CWF product G2A (Fig. A.11) was consolidated from 454.14 g powder on December 14, 2004. When the beaker was removed from the furnace after consolidation, it had an unusually heavy layer of soot on the lower part, and the upper part had a red tarnish.

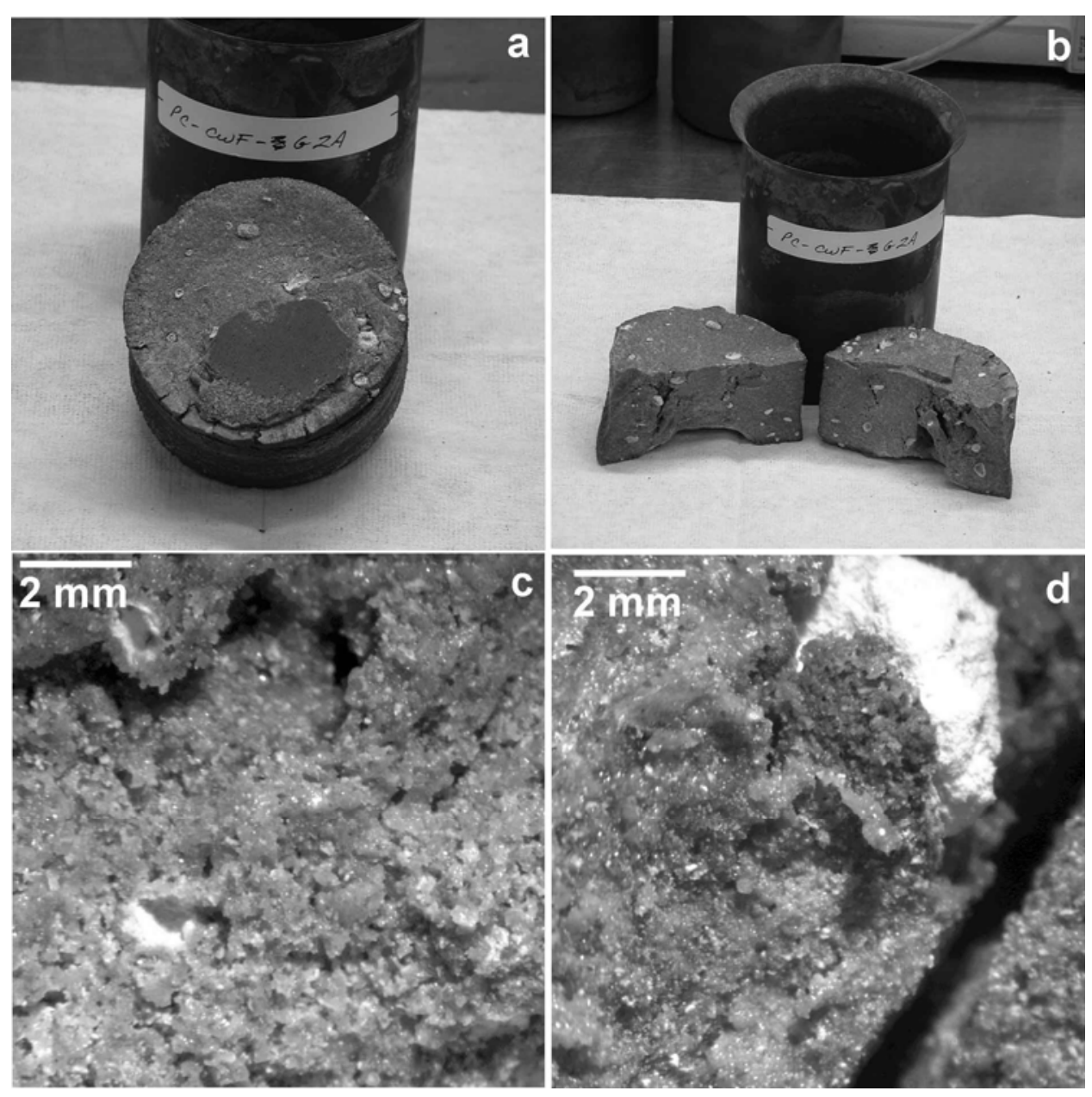

Fig. A.11. PC CWF product G2A contains several white inclusions. 


\section{PC CWF Material G4}

SLZ/Glass Batch G4/1:

Zeolite: $582.68 \mathrm{~g}$ from batch MPE-1 (443.36 g from bottle \#9; remainder from bottle \#8)

Salt: 69.82 grams

Glass: 247.97 grams

Salt occlusion: V-mixer program 2, dates December 20-21, 2004 (a few minutes cold mixing, $\sim 22.5$ hours with furnace, 4.75 hours rotation during cooling, rotation turned off with temperature at $248{ }^{\circ} \mathrm{C}$ ). Results of 3 free-chloride analyses: $0.02 \pm 0.001,0.042 \pm 0.002$, and $0.89 \pm 0.04 \mathrm{mass} \%$.

Glass mixing: 4 hours at room temperature.

Salt-Loaded CWF Product: PC CWF product G4A (Fig. A.12) was consolidated from $400.88 \mathrm{~g}$ powder on December 12, 2004.

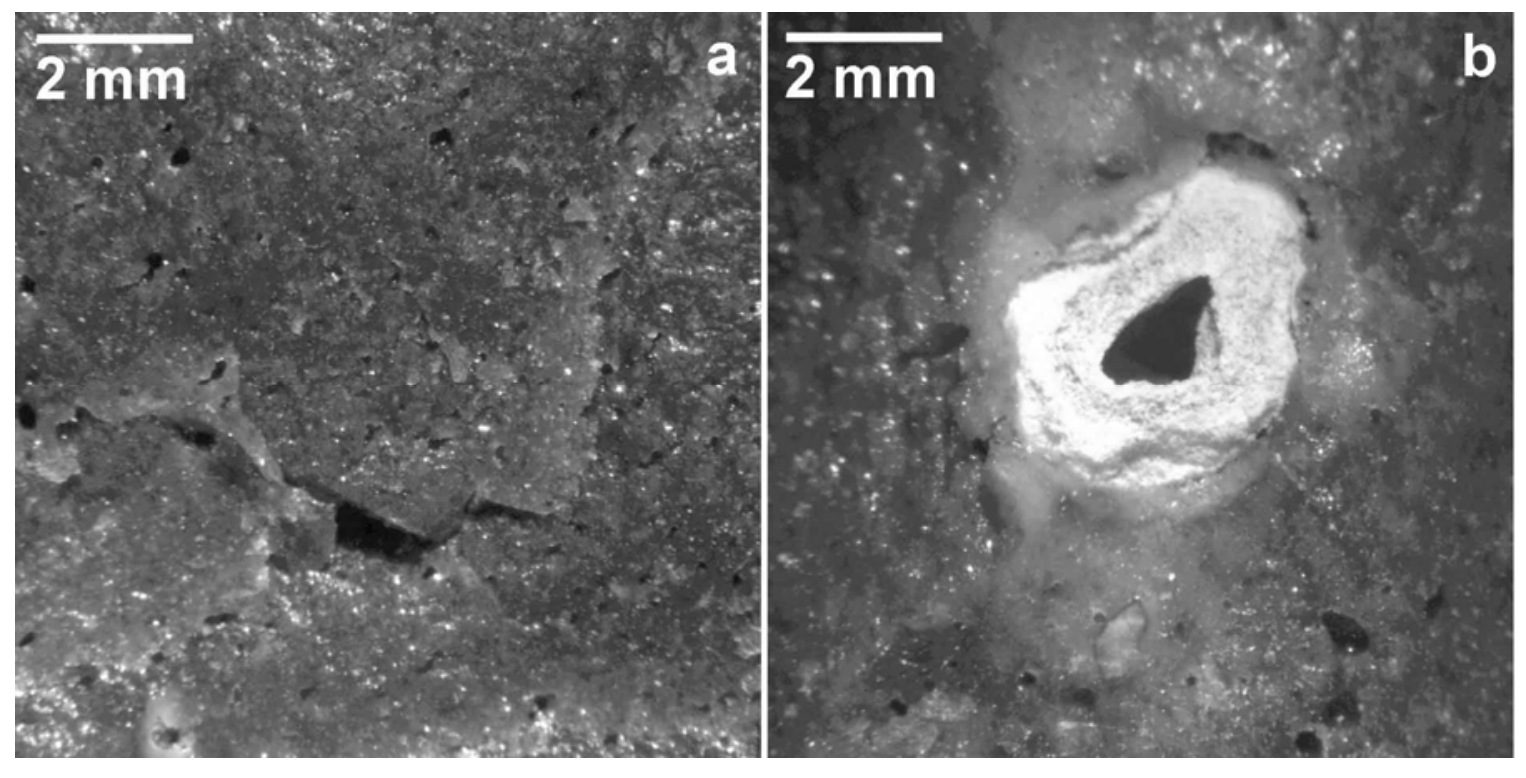

Fig. A.12. PC CWF product G4A. 


\section{PC CWF Material G5}

SLZ/Glass G5 Batch 1:

Zeolite: $~ 562.6 \mathrm{~g}$ from batch MPE-1(523.68 g from bottle \#8; remainder from \#11)

Salt: $67.41 \mathrm{~g}$

Glass: $270.21 \mathrm{~g}$

Salt occlusion: V-mixer program 2, dates January 18-19, 2005 (a few minutes cold mixing, 21.5 hours with furnace, 3.5 hours rotation during cooling, rotation turned off with temperature at 295 ${ }^{\circ} \mathrm{C}$ ). Results of 3 free-chloride analyses: $0.042 \pm 0.004,0.045 \pm 0.005$, and $0.13 \pm 0.007$ mass $\%$.

Glass mixing: 3 hours at room temperature.

Salt-Loaded CWF Product: PC CWF product G5A (Fig. A.13) was consolidated from $401.13 \mathrm{~g}$ powder on January 21, 2005. The 1-liter polyethylene bottle containing the salt-occluded zeolite and glass was allowed to sit in air overnight between being unloaded from the V-mixer and being loaded into the furnace. This was the only waste form product that could not be unloaded from its beaker by banging the bottom or top of the beaker on an anvil, suggesting that it may not have shrunk away from the sides of the beaker as much as the other waste forms.
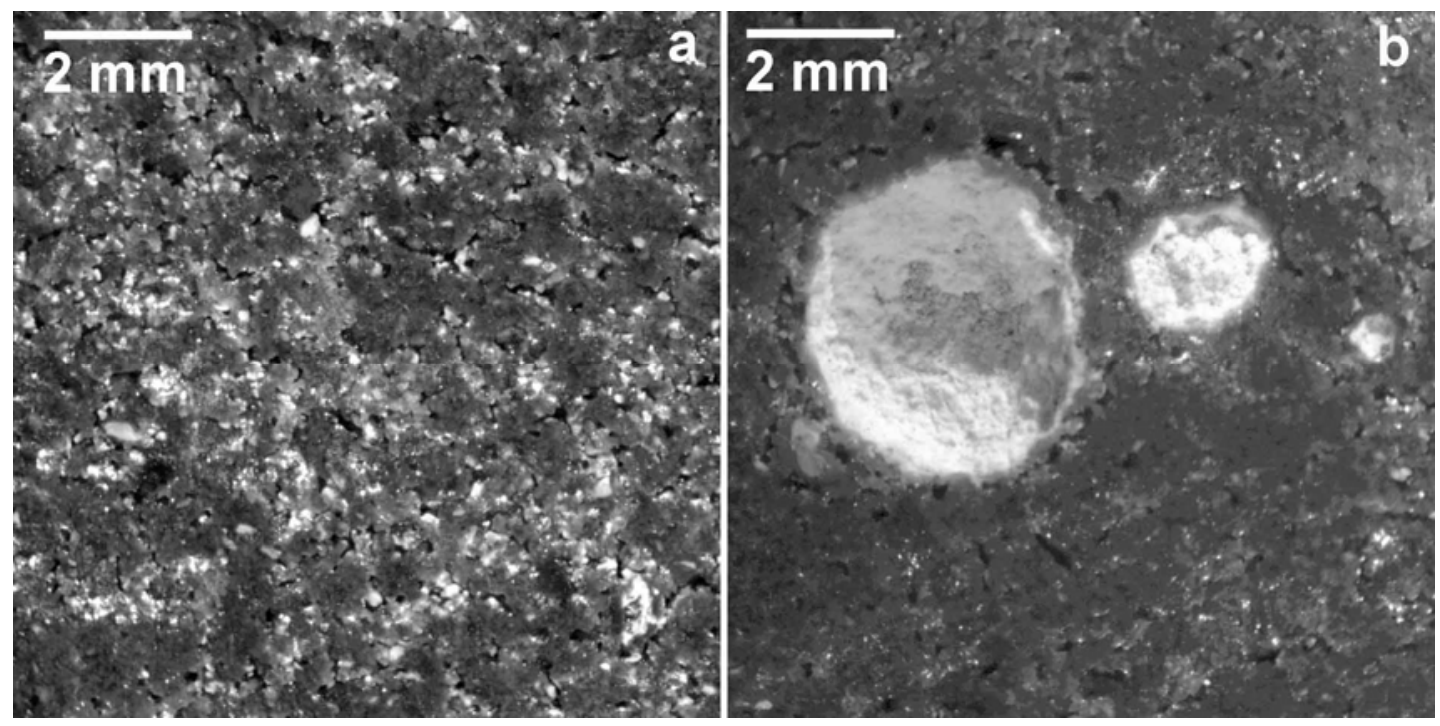

Fig. A.13. PC CWF product G5A is very glassy and dark gray with a slight greenish tint. The waste form has a pronounced conchoidal fracture (characteristic of glassy or very finely crystalline materials, but not of granular ones). White inclusions are common and many do not appear hollow, such as those shown in (b). 


\section{DISCUSSION}

Fissures. Some of the first materials that were synthesized have pronounced fissures extending most of the way through the sample. These fissures can be reduced or avoided if the powdered starting material is settled by tapping the sides and bottom of the beaker until the surface appears firm and the volume stays constant.

Free-chloride analyses and occlusion temperatures. Although the salt is to be occluded in the zeolite at a nominal temperature of $500{ }^{\circ} \mathrm{C}$, the process-control thermocouple indicated that the $\mathrm{V}$-mixer heater was turned off at too low a temperature during occlusion of the SLZ materials made for materials S1 and S2 following temperature program 1. The temperatures registered by the process-control thermocouple for those mixtures were close to $490{ }^{\circ} \mathrm{C}$. The results of freechloride analyses of those SLZ materials were significantly higher than those of other SLZ materials made later using temperature program 2 , which were occluded at $520^{\circ} \mathrm{C}$.

Inclusions. Many of the CWF products contain visible powdery white inclusions. About $0.5 \mathrm{~g}$ of the powdery phase was removed from several inclusions in product G2A using a small pick for powder XRD analysis. The XRD results are summarized in Table A.1 and compared with both results for product $\mathrm{G} 2 \mathrm{~A}$ and the sodalite, nepheline, and halite reference spectra used to interpret the XRD spectra of the CWF products. The assignments of major halite, sodalite, and nepheline peaks to the spectrum of the powdery inclusion material are summarized in Table A.2. The material in the inclusion is composed of the same crystalline phases as CWF G2A and with similar proportions: mostly sodalite with a small amount of halite. A few peaks match those of nepheline. There are only a few additional unidentified peaks in the spectrum of the inclusion material.

Although further carefully designed experiments are required to confirm the ideas presented here, the present data allow tentative suggestions about how the inclusions formed and possible changes to processing techniques that might avoid these inclusions.

Two products were made from the batch 1 materials prepared for PC CWF material S3: PC CWF product $\mathrm{S} 3 \mathrm{~B}$ was made by consolidating powder that had been passed through a 50 mesh sieve, and PC CWF Product S3A was made by consolidating powder that was not sieved. Similarly, PC CWF product S1A was made by consolidating powder from batch 1 material prepared for PC CWF material S1 without sieving, and PC CWF product S1B was produced from sieved powder. The material that did not pass through the sieve consisted of lumps of various sizes, many with irregular lobate shapes. The lumps commonly appeared tan in color and approximately spherical when first seen, but decreased in size and became irregularly lobateshaped during sieving. These lumps seem to consist of hard cores surrounded by relatively soft zeolite powder.

In both cases, the waste forms from unsieved material had numerous powdery inclusions (Figs. A.1 and A.3), while those from sieved material did not. A split of the material from PC CWF material S3 batch 1 that did not pass through the sieve was submitted for X-ray powder diffraction (XRD) analysis. The XRD analysis results are consistent with the identification of this material as a mixture of partially occluded zeolite and something with a halite-like cubic structure. SEM analyses of the powdery white inclusions in PC CWF product S1A after 
consolidation suggested that they consisted of partially occluded zeolite. If it is assumed that reactions between salt and the surrounding material could occur during consolidation (as suggested by differences in the appearance of the CWF material immediately adjacent to the inclusions and that farther away shown in numerous figures), the XRD and SEM results are consistent with each other. These results suggest that the hard lumps in the powdered starting materials may have formed as a mixture of salt and partially occluded zeolite in the V-mixer, then transformed into powdery inclusions of partially occluded zeolite as a result of reactions involving the lumps and surrounding materials during consolidation.

It is also instructive to compare waste forms PC CWF products S3C and S3E (Figs. A.3 and A.4). They have nominally identical compositions and were made using the same $\mathrm{V}$-mixer and furnace heating programs. However, PC CWF product S3C was made with zeolite MPE-1, and PC CWF product S3E was made with zeolite MPE070904. Particle-size ranges for the two batches of zeolite are similar, but zeolite MPE070904 has slightly more of the larger particles (see Table 3). The moisture contents of the two batches of zeolite differed slightly: the bottle of MPE070904 zeolite used to make PC-CWF-S3E had a moisture content of $0.16 \pm 10 \%$ (measured about 6 weeks before the zeolite was used to occlude the salt), while zeolite from the bottle of MPE-1 zeolite used to make PC-CWF-S3C had a moisture content of $0.32 \pm 10 \%$ (measured less than two weeks before the zeolite was used to occlude the salt). Both moisture contents are well below the upper processing limit of 1\% (Goff et al. 1999, p. 19).

Although the difference was not quantified, the flow characteristics of zeolites in batches MPE070904 and MPE-1 were recognizably different. Zeolite MPE070904 readily flowed through the funnels used to transfer it between containers, whereas zeolite MPE-1 required constant tapping or shaking to keep it flowing. The salt-occluded zeolites showed the same difference: when the Vmixer was opened, salt-occluded zeolite MPE-1 did not start flowing out until the V-mixer was tapped with a rubber mallet, while most of the salt-occluded MPE070904 flowed out of the V-mixer as soon as it was opened.

The binder glass and SLZ were mixed overnight before making materials S1A, S2B, and S3C, but were only mixed for a few hours before making the other materials. Using alumina mixing media during salt occlusion of granular zeolite 4A similar to both MPE-1 and MPE070904 caused the zeolite to form hard aggregates up to $15 \mathrm{~cm}$ in diameter. This may indicate that the clay binder phase used to aggregate the zeolite can be damaged during processing.

Another possible difference between MPE-1 and MPE070904 zeolite is that MPE-1 zeolite was dried twice, while MPE070904 zeolite was only dried once. Given uncertainties in precise interpretation of the Karl Fischer measurements, it is not clear whether the ability of the MPE-1 zeolite to rehydrate was impaired by the double drying. However, free-chloride measurements for the S3 SLZ batch 2 made with MPE-1 zeolite and S3 SLZ batch 3 made with MPE070904 zeolite indicate successful salt occlusion in both cases. The free-chloride measurements for both batches are lower than those for S3 SLZ batch 1. This may be a consequence of the lower maximum temperature in the $\mathrm{V}$-mixer.

Simpson and Battisti (1999) also observed that salt occlusion of granular zeolite 4A was essentially complete after 5 hours. Shortening the salt-occlusion and cold-mixing times would increase the maximum production rate for ceramic waste forms, and might also reduce the amounts of 
inclusions formed. All of the available evidence suggests that the formation of inclusions is strongly dependent on relatively small variations in starting materials or processing techniques. 
Table A.1. XRD results for CWF product G2A and isolated powdery inclusion material

\begin{tabular}{|c|c|c|c|c|c|c|c|c|}
\hline \multicolumn{3}{|c|}{ G2A } & \multicolumn{3}{|c|}{ Inclusion material } & \multicolumn{3}{|c|}{ Reference phases } \\
\hline$d(\AA)$ & $\begin{array}{c}1 \% \text { peak } \\
\text { area }\end{array}$ & $\begin{array}{c}\text { I\% peak } \\
\text { height }\end{array}$ & $d(\AA)$ & $\begin{array}{c}\text { I\% peak } \\
\text { area }\end{array}$ & $\begin{array}{c}1 \% \text { peak } \\
\text { height }\end{array}$ & Phase & $\begin{array}{c}\text { I\% peak } \\
\text { height }\end{array}$ & $d(\AA \AA)$ \\
\hline 8.397 & 0.2 & 2.4 & & & & & & 8.397 \\
\hline \multirow[t]{3}{*}{6.365} & 26.5 & 27.5 & 6.356 & 28.3 & 29.5 & Sodalite & 40 & 6.28 \\
\hline & & & 5.405 & 0.1 & 0.2 & & & 5.32 \\
\hline & & & & & & Nepheline & 10 & 5.0058 \\
\hline \multirow[t]{3}{*}{4.472} & 7.3 & 8.9 & 4.471 & 7.8 & 7.4 & Sodalite & 5 & 4.44 \\
\hline & & & & & & Nepheline & 35 & 4.3335 \\
\hline & & & 4.327 & 0.4 & 0.5 & & & 4.31 \\
\hline \multirow[t]{2}{*}{4.254} & 0.2 & 2.8 & & & & & & 4.22 \\
\hline & & & & & & Nepheline & 80 & 4.1766 \\
\hline 4.003 & 0.9 & 4.1 & 3.991 & 1.1 & 1.2 & Sodalite & 1 & 3.97 \\
\hline \multirow[t]{2}{*}{3.874} & 0.1 & 3.3 & & & & Nepheline & 100 & 3.8438 \\
\hline & & & & & & Nepheline & 2 & 3.7614 \\
\hline \multirow[t]{4}{*}{3.645} & 100 & 100 & 3.642 & 100 & 100 & Sodalite & 100 & 3.624 \\
\hline & & & 3.545 & 0.4 & 0.5 & & & 3.52 \\
\hline & & & 3.476 & 1.2 & 1.3 & & & 3.45 \\
\hline & & & 3.337 & 1.0 & 0.8 & & & 3.32 \\
\hline \multirow{4}{*}{3.286} & 0.7 & 3.7 & 3.292 & 2.1 & 1.5 & Nepheline & 70 & 3.2731 \\
\hline & & & & & & Halite & 13 & 3.26 \\
\hline & & & 3.253 & 1.3 & 0.8 & & & 3.23 \\
\hline & & & 3.168 & 2.4 & 2.0 & & & 3.14 \\
\hline \multirow[t]{6}{*}{3.091} & 0.2 & 3.1 & & & & & & 3.07 \\
\hline & & & & & & Nepheline & 18 & 3.0461 \\
\hline & & & & & & Nepheline & 100 & 3.0059 \\
\hline & & & 2.964 & 0.6 & 0.6 & & & 2.94 \\
\hline & & & 2.942 & 0.7 & 0.7 & & & 2.92 \\
\hline & & & & & & Nepheline & 35 & 2.8864 \\
\hline 2.845 & 7.4 & 6.7 & 2.845 & 19.6 & 11.2 & Halite & 100 & 2.821 \\
\hline 2.817 & 9.9 & 10.5 & 2.814 & 11.5 & 8.6 & Sodalite & 8 & 2.807 \\
\hline \multirow[t]{3}{*}{2.570} & 21.2 & 20.3 & 2.567 & 21.9 & 19.2 & Sodalite & 16 & 2.563 \\
\hline & & & & & & Nepheline & 14 & 2.50 \\
\hline & & & & & & Nepheline & 10 & 2.4007 \\
\hline \multirow[t]{3}{*}{2.378} & 21.1 & 19.8 & 2.377 & 21.7 & 18.1 & Sodalite & 16 & 2.373 \\
\hline & & & & & & Nepheline & 35 & 2.3395 \\
\hline & & & & & & Nepheline & 25 & 2.3074 \\
\hline \multirow[t]{4}{*}{2.223} & 1.3 & 2.8 & 2.219 & 2.4 & 1.3 & Sodalite & 1 & 2.219 \\
\hline & & & & & & Nepheline & 5 & 2.163 \\
\hline & & & & & & Nepheline & 7 & 2.1188 \\
\hline & & & & & & Nepheline & 5 & 2.0938 \\
\hline 2.096 & 31.6 & 25.5 & 2.094 & 30.9 & 24.1 & Sodalite & 20 & 2.093 \\
\hline 2.006 & 3.7 & 3.3 & 2.006 & 7.4 & 3.6 & Halite & 55 & 1.994 \\
\hline \multirow[t]{2}{*}{1.987} & 5 & 5.4 & 1.985 & 5.4 & 4.2 & Sodalite & 3 & 1.985 \\
\hline & & & & & & Nepheline & 6 & 1.9313 \\
\hline \multirow[t]{2}{*}{1.894} & 4.4 & 4.8 & 1.892 & 4.6 & 3.2 & Sodalite & 3 & 1.893 \\
\hline & & & & & & Nepheline & 2 & 1.8411 \\
\hline \multirow[t]{2}{*}{1.813} & 3.7 & 3.6 & 1.812 & 4.2 & 3.1 & Sodalite & 2 & 1.8122 \\
\hline & & & & & & Nepheline & 5 & 1.7923 \\
\hline \multirow[t]{2}{*}{1.742} & 4.7 & 4.4 & 1.740 & 4.2 & 3.3 & Sodalite & 2 & 1.7413 \\
\hline & & & & & & Nepheline & 5 & 1.6942 \\
\hline 1.635 & 1.8 & 2.1 & 1.636 & 2.1 & 1.0 & Nepheline & 6 & 1.6346 \\
\hline & & & & & & Halite & 15 & 1.628 \\
\hline 1.621 & 3.2 & 4.0 & 1.620 & 2.9 & 1.9 & Sodalite & 2 & 1.621 \\
\hline & & & & & & Nepheline & 8 & 1.615 \\
\hline & & & & & & Nepheline & 4 & 1.6002 \\
\hline
\end{tabular}


Table A.1. (continued)

\begin{tabular}{|c|c|c|c|c|c|c|c|c|}
\hline \multicolumn{3}{|c|}{} & \multicolumn{3}{c|}{ Inclusion material } & \multicolumn{3}{c|}{ Reference phases } \\
\hline$d(\AA)$ & $\begin{array}{c}\text { I\% peak } \\
\text { area }\end{array}$ & $\begin{array}{c}\text { I\% peak } \\
\text { height }\end{array}$ & $d(\AA)$ & $\begin{array}{c}\text { I\% peak } \\
\text { area }\end{array}$ & $\begin{array}{c}\text { I\% peak } \\
\text { height }\end{array}$ & Phase & $\begin{array}{c}\text { I\% peak } \\
\text { height }\end{array}$ & $d(\AA)$ \\
\hline 1.569 & 12.9 & 10.1 & 1.568 & 13.4 & 8.4 & Sodalite & 5 & 1.5696 \\
\hline & & & & & & Nepheline & 14 & 1.5614 \\
\hline 1.523 & 6.8 & 5.3 & 1.522 & 6.6 & 4.4 & Sodalite & 3 & 1.5227 \\
\hline 1.479 & 9.7 & 7.3 & 1.478 & 9.2 & 6.0 & Sodalite & 4 & 1.4797 \\
\hline & & & & & & Nepheline & 5 & 1.4687 \\
\hline & & & & & & Nepheline & 3 & 1.4555 \\
\hline 1.439 & 10.9 & 7.7 & 1.439 & 10.2 & 6.6 & Sodalite & 5 & 1.4404 \\
\hline & & & & & & Nepheline & 7 & 1.4282 \\
\hline & & & & & & Halite & 6 & 1.41 \\
\hline 1.402 & 0.5 & 1.7 & 1.402 & 0.5 & 0.5 & Sodalite & 1 & 1.4038 \\
\hline & & & & & & Nepheline & 6 & 1.3865 \\
\hline 1.369 & 4.5 & 3.8 & 1.369 & 4.8 & 2.8 & Sodalite & 2 & 1.3699 \\
\hline 1.338 & 4.8 & 3.8 & 1.337 & 5.1 & 2.8 & Sodalite & 2 & 1.3385 \\
\hline 1.307 & 5.2 & 3.4 & 1.307 & 4.3 & 2.6 & Sodalite & 2 & 1.3091 \\
\hline & & & 1.304 & 2.6 & 1.7 & & & 1.30 \\
\hline 1.280 & 2.8 & 2.8 & 1.279 & 2.7 & 1.7 & Sodalite & 2 & 1.2814 \\
\hline & & & & & & Nepheline & 6 & 1.279 \\
\hline 1.264 & 0.8 & 1.5 & 1.267 & 2.0 & 0.9 & Sodalite & 1 & 1.2684 \\
\hline & & & & & & Sodalite & 1 & 1.2555 \\
\hline 1.230 & 0.7 & 1.5 & & & & Nepheline & 4 & 1.2347 \\
\hline 1.207 & 8.5 & 5.5 & 1.206 & 7.8 & 4.5 & Sodalite & 3 & 1.2081 \\
\hline
\end{tabular}


Table A.2. Summary of relative XRD peak heights and peak areas for isolated powdery inclusion material

\begin{tabular}{|c|c|c|c|c|c|c|c|c|}
\hline \multirow{2}{*}{$\begin{array}{c}d \text {-spacing, } \\
\AA\end{array}$} & \multicolumn{2}{|c|}{ Halite } & \multirow{2}{*}{$\underset{\AA}{d-s p a c i n g}$} & \multicolumn{2}{|c|}{ Sodalite } & \multirow{2}{*}{$\begin{array}{c}d \text {-spacing, } \\
\AA\end{array}$} & \multicolumn{2}{|c|}{ Nepheline } \\
\hline & $\begin{array}{c}\text { \% peak } \\
\text { area }\end{array}$ & $\begin{array}{c}\text { \% peak } \\
\text { height }\end{array}$ & & $\begin{array}{c}\text { \% peak } \\
\text { area }\end{array}$ & $\begin{array}{c}\text { \% peak } \\
\text { height }\end{array}$ & & $\begin{array}{c}\text { \% peak } \\
\text { area }\end{array}$ & $\begin{array}{c}\% \text { peak } \\
\text { height }\end{array}$ \\
\hline 3.26 & $\mathrm{nd}^{\mathrm{a}}$ & nd & 6.28 & 28.3 & 29.5 & 4.3335 & nd & nd \\
\hline 2.821 & 19.6 & 11.2 & 3.624 & 100 & 100 & 4.1766 & nd & nd \\
\hline 1.994 & 7.4 & 3.6 & 2.563 & 21.9 & 19.2 & 3.8438 & nd & nd \\
\hline 1.628 & nd & nd & 2.373 & 21.7 & 18.1 & 3.2731 & 2.1 & 1.5 \\
\hline 1.41 & nd & nd & 2.093 & 30.9 & 24.1 & 3.0059 & nd & nd \\
\hline & & & & & & 2.8864 & nd & nd \\
\hline & & & & & & 2.3395 & nd & nd \\
\hline
\end{tabular}

a'Entry of "nd" means peak was not detected

\section{REFERENCES}

Goff, K.M., Ackerman, J.P., Simpson, M.F., Hash, M.C., Bateman, K.J., Battisti, T.J., Hirsche, K.L., and Kennedy, J.R. 1999. Ceramic Waste Form Process Qualification Plan. Argonne National Laboratory Report ANL-NT-118.

Simpson, M.F., and Battisti, T.J. 1999. "Adsorption of Eutectic LiCl-KCl into Zeolite 4A Using a Mechanically Fluidized Vacuum System.” Ind. Eng. Chem. Res. 38:2469-2473. 
Distribution for ANL/05-32

Internal (Printed and Electronic Copies):

W. L. Ebert (15)

Internal (Printed Copy Only):

M. J. Steindler

Internal (Electronic Copy Only):
M. R. Hale, TIS
J. A. Fortner
D. P. Abraham
E. K. Fujita
C. H. Adams
C. Grandy
R. K. Ahluwalia
D. J. Graziano
T. H. Bauer
R. N. Hill
A. R. Brunsvold
J. L. Jerden, Jr.
D. B. Chamberlain
H. S. Khalil
Y. I. Chang
J. J. Laidler
J. C. Cunnane
L. Leibowitz
T. H. Fanning
R. M. Lell
R. J. Finch
D. Lewis
A. A. Foley
M. A. Lewis

C. J. Mertz

E. E. Morris

M. T. Peters

M. C. Regalbuto

C. T. Snyder

V. S. Sullivan

Y. Tsai

G. F. Vandegrift

R. A. Wigeland

M. A. Williamson

J. L. Willit 
External (Printed and Electronic Copies):

R. W. Benedict, Idaho National Laboratory, Idaho Falls, ID (10)

K. M. Goff, Idaho National Laboratory, Idaho Falls, ID

D. E. Janney, Idaho National Laboratory, Idaho Falls, ID

D. D. Keiser, Jr., Idaho National Laboratory, Idaho Falls, ID

T. P. O'Holleran, Idaho National Laboratory, Idaho Falls, ID

\section{External (Electronic Copies Only):}

M. A. Buckley, ANL Library-E

S. E. Aumeier, Idaho National Laboratory, Idaho Falls, ID

K. J. Bateman, Idaho National Laboratory, Idaho Falls, ID

T. J. Battisti, Idaho National Laboratory, Idaho Falls, ID

S. S. Cunningham, Idaho National Laboratory, Idaho Falls, ID

D. B. Davies, Idaho National Laboratory, Idaho Falls, ID

H. E. Garcia, Idaho National Laboratory, Idaho Falls, ID

S. G. Johnson, Idaho National Laboratory, Idaho Falls, ID

M. G. Gougar, Idaho National Laboratory, Idaho Falls, ID

D. D. Hagan, Idaho National Laboratory, Idaho Falls, ID

K. L. Howden, Idaho National Laboratory, Idaho Falls, ID

J. R. Kennedy, Idaho National Laboratory, Idaho Falls, ID

C. J. Knight, Idaho National Laboratory, Idaho Falls, ID

J. R. Krsul, Idaho National Laboratory, Idaho Falls, ID

C. E. Lahm, Idaho National Laboratory, Idaho Falls, ID

G. L. Lentz, Idaho National Laboratory, Idaho Falls, ID

S. X. Li, Idaho National Laboratory, Idaho Falls, ID

R. P. Lind, Idaho National Laboratory, Idaho Falls, ID

K. C. Marsden, Idaho National Laboratory, Idaho Falls, ID

S. D. McBride, Idaho National Laboratory, Idaho Falls, ID

H. F. McFarlane, Idaho National Laboratory, Idaho Falls, ID

R. L. Parks, Idaho National Laboratory, Idaho Falls, ID

R. D. Phipps, Idaho National Laboratory, Idaho Falls, ID

C. L. Pope, Idaho National Laboratory, Idaho Falls, ID

S. R. Sherman, Idaho National Laboratory, Idaho Falls, ID

G. M. Teske, Idaho National Laboratory, Idaho Falls, ID

D. E. Vaden, Idaho National Laboratory, Idaho Falls, ID

D. L. Wahlquist, Idaho National Laboratory, Idaho Falls, ID

B. R. Westphal, Idaho National Laboratory, Idaho Falls, ID 